\title{
MODERN PROBLEMS OF HISTORY OF SCIENCE AND BIOGRAPHICAL STUDY
}

Collective monograph

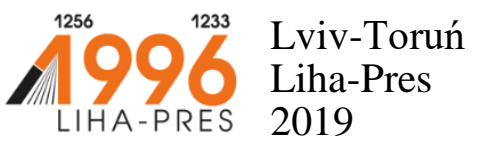




\section{Reviewers:}

Prof. dr hab. Sabina Grabowska, Uniwersytet Rzeszowski / University of Rzeszow (Republic of Poland);

Prof. dr hab. Joanna Marszalek-Kawa, Uniwersytet Mikołaja Kopernika $w$ Toruniu / Nicolaus Copernicus University (Republic of Poland).

Modern problems of history of science and biographical study : collective monograph / R. Bey, S. Hordenko, N. Kovalenko, O. Korzun, N. Kotsur, V. Melnyk, V. Orekhivskyi, V. Vergunov. - Lviv-Toruń : Liha-Pres, 2019. - 184 p.

ISBN 978-966-397-148-3

Liha-Pres is an international publishing house which belongs to the category "C" according to the classification of Research School for Socio-Economic and Natural Sciences of the Environment (SENSE) [isn: 3943, 1705, 1704, 1703, 1702, 1701; prefixMetCode: 978966397]. Official website www.sense.nl. 


\section{CONTENTS}

SCIENTIFIC ACTIVITY OF A.S. SEREBROVSKYI (1892-1948) IN THE CONTEXT OF THE DEVELOPMENT OF FARM ANIMAL GENETICS

Roman Bey 1

LEADING TRENDS OF AGRICULTURAL EDUCATION DEVELOPMENT IN THE $19^{\mathrm{TH}}$ - AT THE BEGINNING OF THE $20^{\text {TH }}$ CENTURY

Svetlana Hordenko

ECOLOGIZATION OF AGRICULTURAL PRODUCTION: DEVELOPMENT OF INTRODUCTION OF INNOVATIVE TECHNOLOGIES IN UKRAINE AT THE BEGINNING OF THE 21 ${ }^{\text {ST }}$ CENTURY

Nataliia Kovalenko .41

PECULIARITIES OF STATE REGULATION OF SCIENTIFIC RESEARCHES IN THE AGRICULTURAL SPHERE IN THE UKRAINIAN SOVIET SOCIALIST REPUBLIC DURING THE PERIOD OF RECONSTRUCTION (1943-1945)

Olena Korzun .65

ESTABLISHMENT AND DEVELOPMENT OF SCIENTIFIC FOUNDATIONS OF THE SANITARY AND HYGIENIC SCIENCE IN UKRAINE (SECOND HALF OF THE $19^{\mathrm{TH}}$ BEGINNING OF THE $20^{\mathrm{TH}}$ CENTURIES)

Nadiya Kotsur 92 
SOCIO-ECONOMIC AND ORGANIZATIONAL FACTORS

OF POULTRY FARMING DEVELOPMENT

IN THE UKRAINIAN SSR IN 1964-1971

Victoriia Melnyk

EVOLUTION OF THE SCIENTIFIC-ORGANIZATIONAL FOUNDATIONS OF ORGANIC FARMING IN UKRAINE: HISTORIOGRAPHY OF THE INDEPENDENCE PERIOD

Volodymyr Orekhivskyi

CONSTRUCTION OF AGRICULTURAL RESEARCH IN THE CRIMEAN PENINSULA

Viktor Vergunov. 155 


\section{SCIENTIFIC ACTIVITY OF A.S. SEREBROVSKYI (1892-1948) IN THE CONTEXT OF THE DEVELOPMENT OF FARM ANIMAL GENETICS}

\section{Roman Bey}

\section{INTRODUCTION}

Achievements of modern molecular genetics, technology of cloning organisms, DNA technologies are largely associated with significant theoretical and practical work of domestic geneticists of the 1920's-1940's. Among intellectual elite a significant role belongs to A.S. Serebrovskyi - one of the prominent Soviet geneticists, whose creative heritage was intensely ignored in the first, and was largely not appreciated in the second half of the last century.

Some aspects of the scientist's activities were highlighted in the scientific works by M.M. Aslanian, N.B. Varshaver, N.V. Glotov', A. Bezzubtsev-Kondakov ${ }^{2}$, V. Soifer ${ }^{3}$ and other authors. But to this day, a comprehensive study of his creative activity, an analysis of scientific heritage has not yet been carried out.

The purpose of this article in the context of historical events associated with the development of domestic and world genetics during the first half of the 20th century is to present biographical data that highlights the life and fate of the famous geneticist A.S. Serebrovskyi in science; and also consider his contribution to genetics and, in general, to biological science, focusing on the scale of his ideas, its perception by contemporaries of the scientist and the significance of these ideas for our time.

The general scientific and interdisciplinary methods used to solve research tasks. Particular attention paid to special historical methods,

\footnotetext{
${ }^{1}$ Aslanian, M. M., Varshaver, N. B., \& Glotov, N. V. (1993) Aleksandr Sergeevich Serebrovskii [Aleksandr Sergeevich Serebrovskii]. Moscow, 192 s. (in Russian).

${ }^{2}$ Bezzubtcev-Kondakov, A. (2003) Evgenika kak "prokliatyi vopros» XX veka. $\mathrm{Za}$ [Eugenics as a "damned question" of the 20th century]. Russkoe delo, no. 4 (106), pp. 12-24. (in Russian).

${ }^{3}$ Soifer, V. (2004). Zagublennyi talant (Istoriia zhizni odnogo laureata) [Ruined talent (Life story of one laureate)]. Vashington, 415 s. (in Russian).
} 
source analysis. The source base of the research includes a complex of diverse documents, the basis of which are archival materials.

The article is prepared in accordance with the tasks of the state budget topic 0116U002102 "Scientific-organizational and regulatory bases of innovative activity in the system of agrarian science: theoretical and methodological, historical and scientific studies, archival, bibliographic aspects of the research".

\section{Formation of scientific outlook of A.S. Serebrovskyi. Contribution to the development of genography of species of farm animals}

A. Serebrovskyi was born on February 12, 1892 in Kursk in the family of an architect. Alexander's childhood and youth coincide with the first stage of the development of a new science - genetics. These were the years of fundamentally important discoveries in genetics, the years of its formation. At that time, the basic concepts of the mutation theory were formed, the law of the independent frequency distribution of genotypes and phenotypes in the population was established, the phenomenon of gene interaction was identified, work began on the development of the chromosome theory and was accumulated on the mechanisms of inheritance of characters. Often, theoretical thought did not keep pace with the explanation of open phenomena. By that time, Russia had developed original directions in various fields of biology, and two Russian biologists were awarded by the Nobel Prize I.I. Mechnikov and I.P. Pavlov (1904) ${ }^{4}$.

The first optional course in genetics in Russia began to be taught at the University of St. Petersburg by zoologist Y. Filipchenko (1882-1930) as early as 1913, and five years later, he organized the first department of experimental zoology and genetics in Russia. N. Vavilov (1887-1943) moved to Petrograd from Saratov, who in a short time managed to create an ensemble of first-class researchers around him. In such conditions, there was a rapid development of domestic genetics in St. Petersburg. In Moscow in 1916, on the basis of the Moscow Society of Scientific Institution, N. Koltsov (1872-1940),

\footnotetext{
${ }^{4}$ Aslanian, M. M., Varshaver, N. B., \& Glotov, N. V. (1993) Aleksandr Sergeevich Serebrovskii [Aleksandr Sergeevich Serebrovskii]. Moscow, 192 s. (in Russian).
} 
whom the famous German zoologist and geneticist R. Goldschmidt called the most educated of all biologists known to him, creates the first in Europe Institute of Experimental Biology. Four years later, $\mathrm{N}$. Koltsov invited the zoologist S. Chetverikov to organize a genetic laboratory at the institute. The famous scientists such as N. TimofeevRostovsev, B. Astaurov, S. Gershenzon, N. Dubinin, E. Balkashina, D. Romashov originates from Moscow School of Genetics. Thanks to Koltsov's school in genetics, the name of A. Serebrovskyi became widely known. In 1909, after completing his studies at the Tula Real School, entered the natural department of the Physics and Mathematics Faculty of Moscow University. He with M. Zavadovskyi, also a university student, were taking practical classes with of N. Koltsov on the invertebrate zoology course at A. Shaniavskyi People's University. After graduating from university in 1914, A. Serebrovskyi enlisted as a volunteer in the army, graduated from the school of ensigns in 1916 and for the next two years was in the army on the Caucasian front. After demobilization, he returned to Moscow to his teacher N. Koltsov and he invited him to deal with issues of private animal genetics. Soon, in 1919, he moved to the v. Slobodka, Tula Region, where an Experimental Poultry Station was organized. He researched the problem of hen genetics and his first work was devoted to the genetics of farm animals, which opened a new direction in animal husbandry. The choice of domestic chicken as an object of genetics was not accidental. A short reproductive period, high fecundity costs for conducting genetic studies allow him to achieve the significant results ${ }^{5}$.

Since 1921, A. Serebrovskyi had worked at the Anikovska Experimental Station near Zvenigorod, organized with the participation of N. Koltsov, and at the same time is listed as an assistant to the N. Koltsov Institute of Experimental Biology. At the same time, a wide range of interests of A. Serebrovskyi began to manifest himself - from issues of general biology and evolutionary teachings to specific issues of breeding individual species of agricultural animals.

High activity allowed him to conduct work in parallel in various scientific and educational institutions. From 1923-1924 A. Sereb-

${ }^{5}$ Serebrovskii, A. S. (1919) Izuchenie nasledstvennosti selskokhoziaistvennykh zhivotnykh [The study of the heredity of farm animals]. Trudovoe khoz-vo, no. 5, pp. 19-20. (in Russian). 
rovskyi successfully combines the head of the poultry department of the Moscow Zootechnical Institute (later this department was transformed into the department of genetics) and lecturing the course "Genetic analysis of farm animals" at Moscow State University. The publication in 1923 of the first edition of his book "Biological Walks", in which he expressed his deeply spiritual attitude to nature ${ }^{6}$. According to this book, which has become an example of a combination of science and poetry, many natural biologists studied.

This period of A. Serebrovskyi's life passes under events exciting the imagination of geneticists: a chromosome theory of heredity, $\mathrm{N}$. Vavilov formulates his famous law of homological series and establishes centers of origin of cultivated plants, the work of $\mathrm{S}$. Chetverikov on evolutionary genetic processes in populations is being developed. It should be noted that, despite the first wave of emigration of Russian intelligentsia to the West, the intellectual potential of geneticists of the former USSR and its contribution to the world level of development of genetics of that period was so significant that the V International Genetic Congress in Berlin (1927) noted the exceptional importance of the achievements of Soviet genetics of that period. This was the first and, unfortunately, the last triumph of domestic genetics of the 20th century.

N. Vavilov, C. Chetverikov, A. Serebrovskyi impressed by the evolutionary and genetic ideas, began to develop a new direction, which he called genogeography. The concept of "genogeography" was introduced into science by A. Serebrovsky in conjunction with the concept of "gene pool". However, the scientific fate of these new ideas turned out to be just as, and even more, perverse, as the fate of domestic genetics as a whole. After all the tragic breakdowns in the history of genetics in our country, since the 1960's, the era of its revival began. The ideas of genogeography and the gene pool still remain an undeveloped scientific heritage ${ }^{7}$.

In the late 1920's, the next stage in the development of genetics began, marked by the discovery of the possibility of artificially

\footnotetext{
${ }^{6}$ Serebrovskii, A. S. (1973) Biologicheskie progulki [Biological walks]. 3-e izd., sokr. Moscow, 68 s. (in Russian).

${ }^{7}$ Rychkov, Yu. G., Zhukova, O. V., \& Evsiukov, A. N. (2001). Genofond $i$ genogeografiia narodonaseleniia [The gene pool and population genogeography]. $\mathrm{SPb}$, vol. 1, 611 s. (in Russian).
} 
producing mutations. Biologists did not abandon the hope of artificially changing genes. N. Koltsov set his task to his students, but to no avail. However, in Leningrad in 1925, microbiologists G. Nadson and G. Filipov published a work on artificially induced mutations in yeast under the influence of radiation. Unfortunately, the conclusion of scientists about the mutagenic effect of radiation A. Serebrovskyi then rejected, saying that the yeast has no nucleus, no chromosomes, and therefore the changes obtained by G. Nadson and G. Filipov are not mutations, but, as he called them, long-term modifications. As a result, then the most important discovery of Russian scientists-genetics did not listen. But, when in 1927 G. Meller induced mutations in experiments using $\mathrm{X}$-ray radiation on Drosophila, this was perceived in world science as an outstanding discovery, for which after almost twenty years he was awarded by the Nobel Prize.

A. Serebrovskyi was shocked by G. Meller's work. In the newspaper Pravda of September 11, 1927, his article was published about this discovery under the intriguing title "The Four Pages That Excited the Scientific World". The discovery of the mutagenic properties of x-ray radiation was the starting point for a new round of development by A. Serebrovskyi of the central problem of the doctrine of heredity - the gene problem.

A. Serebrovskyi was the first in the world to disprove the fundamental conclusion about the impossibility of fragmenting the gene. He suggested that one part (the "center of the gene"), rather than the entire gene, could be mutated. Reporting at the All-Russian Congress of Zoologists, Anatomists and Histologists in Leningrad (1927), A. Serebrovskyi said that many genetics that were not clear at that time would be resolved, "if only we reject the seriously unreasonable idea of a gene as an isolated morphological parts of the chromosome that is not crushable" ${ }^{\prime 2}$. Logically developing the idea of gene divisibility, A. Serebrovskyi soon came to the conclusion that not only genes are located on the chromosome linearly, as was established by T. Morgan, but the gene itself is linear and has a certain length. In addition, he puts forward an important hypothesis in which he considers

\footnotetext{
${ }^{8}$ Serebrovskii, A. S. (1928). Problema gena i ego izmerenie [The problem of the gene and its measurement]. Tr. Vseros. sezda zoologov, anatomov $i$ gistologov, Leningrad, 14-20 dek., p. 51. (in Russian).
} 
the chromosome as a giant molecule. These revolutionary thoughts were expressed in 1926-1928, decades before it was found that the DNA molecule was shown to be the bearer of heredity and the gene was shown to be a segment of a linear DNA molecule.

Based on the assumption that the gene is extended, that it is linear, it is divisible, and when multiple alleles occur, sections of different lengths can fall out, A. Serebrovskyi in 1928 organized an experimental test of his hypothesis. The experiments to study the possibility of gene fragmentation by x-ray irradiation, begun at the Moscow Zootechnical Institute, were continued by him at the K.A. Timiryazev Biological Institute with the help of his students and staff, most of which left a noticeable mark on the history of Russian genetics. The collective work carried out under his leadership confirmed the correctness of his idea, which led to the discovery of the phenomenon of gradual allelomorphism and the creation of a theory of the complex structure of the gene (the central theory of the gene) ${ }^{9}$.

The theory of stepwise allelomorphism, suggesting the divisibility of gene, caused sharp objections from the largest geneticists, such as Stertevant, Shulyts, Goldschmidt. Highly appreciating the level of work of A. Serebrovskyi and his school, each of them offered his own interpretation of the results obtained, which, however, would leave intact the idea of the gene as an elementary unit of heredity. Subsequently, with the development of molecular biology, these postulates were fully confirmed, but the name of A. Serebrovskyi, who formulated them back in the late 1920's, is not mentioned anywhere.

From this period, extremely intense scientific and organizational activities of A. Serebrovskyi have been noted. In 1929, in addition to organizing the laboratory of genetics at the Timiryazev Biological Institute, he heads the cabinet of heredity and the constitution of a person at the Medical and Biological Institute (later the M. Gorky Medical and Genetic Institute), whose director was A. Serebrovskyi's former employee S. Levit. In 1930, after the dismissal, the arrest and expulsion from Moscow of S. Chetverikov, A. Serebrovskyi organized the department of genetics at the university and became its head. Then,

\footnotetext{
${ }^{9}$ Serebrovskii, A. S., \& Dubinin, N. P. (1929). Iskusstvennoe poluchenie mutatcii $i$ problema gena [Artificial mutation and gene problem]. Uspekhi eksperim. biologii. Ser. Biologiia, vol. 8, vyp. 4, pp. 235-247. (in Russian).
} 
without leaving other places of work, Serebrovskyi establishes the Department of Genetics and Animal Breeding at the All-Union Institute of Livestock of All-Union Academy of Agricultural Sciences named after Lenin and in the future manages it, as well as manages the laboratory in the Caucasus (in Dagestan) and the group in Middle Asia. For a number of years, he was simultaneously an employee of the Presidium of Academy and for some time served as Vice president of Academy. In addition, in the period from 1926 to 1939 A.S. Serebrovskyi was the initiator of numerous discussions on controversial issues of genetics. It was hard to say how to combine these many responsibilities, but it is well known that he was a productive scientist and a wonderful teacher, he was highly appreciated by students of the biology faculty of Moscow State University, his lectures on genetics aroused great interest and woke up the thought of young students. It was from this department that many talented genetics of the country came out. Among the personal factors of A. Serebrovskyi, which, according to the pupils, contributed to their extremely active diverse research and pedagogical activities, they called originality, ingenuity, a certain eccentricity, liveliness of mind, and the ability to be easily inspired. He was an inborn teacher, clearly and clearly bringing to the minds of listeners the position of his ideas, and at the same time a brilliant polemicist, acutely ridiculing the stupidity and ignorance of his opponents. He was a strong analyst and mathematician, and used his mathematical mindset in the development of a number of theoretical principles of genetics.

A. Serebrovskyi very early began to gravitate to philosophical and ideological discussions about science and about its new tasks in a socialist society. He attached great importance to the implementation of communist ideas in biological research and the transfer of biological ideas into communist ideology. He enthusiastically engaged in disputes over the benefits that the socialist system opens up to society and science, applied for membership in the CPSU and was accepted as a candidate for party membership. He became a staunch supporter of the correctness of Marxist-Leninist ideology in the development of human society.

From the beginning of the 1920's A. Serebrovskyi began to publish articles not only on problems of general genetics and animal genetics, but also on human inheritance. However, its introduction into 
this problem caused a significant negative resonance in different circles. Serebrovskyi's work on human heredity was initiated by N. Koltsov. At that time, N. Koltsov was the main inspirer of the development of eugenics in Russia - the science of the conscious direction and acceleration of human evolution in order to achieve the greatest perfection of man as a biological species. The ancestor of eugenics in the second half of the 20th century became F.Galton - a cousin of Ch. Darwin. A lively interest in Galton's ideas arose in a number of countries at the beginning of the 20th century. Then, thanks in large part to K. Timiryazev, they also heard about eugenics in Russia, but it reached its peak somewhat later, in the 1920's. Eugenic ideas turned out to be in tune with the daunting task of creating a man of the future, which the leaders of the new, Soviet .Russia dreamed of in the post-revolutionary years, and therefore eugenics has found especially fertile soil for itself here ${ }^{10}$. Over time, A. Serebrovskyi also joined the movement of Russian Eugenists. His vision of the practical application of eugenic ideas is most clearly presented in the article "Anthropogenetics and eugenics in a socialist society", published in 1929 and provoked harsh criticisms ${ }^{11}$.

It is easy to imagine what a wave of public condemnation these reasonings provoked. In response to the criticism that fell upon him, A. Serebrovskyi acknowledged the fallacy of some of his previous allegations. All this in a complex, taking into account the unambiguous trends of that dangerous time, as well as the significant public weight of A. Serebrovskyi as a scientist and popular teacher, could very well lead to the realization of his ideas, which would pose a significant threat to the nation. On the other hand, the creation of a society of "ideal" people, perhaps, was not at all included in the plans of totalitarian power in the USSR.

Soon, eugenics, as well as genetics, was finished in the Soviet Union. The distortion of eugenic ideas in Germany and other countries

${ }^{10}$ Serebrovskii, A. S. (1919) Izuchenie nasledstvennosti selskokhoziaistvennykh zhivotnykh [The study of the heredity of farm animals]. Trudovoe khoz-vo, no. 5, pp. 19-20. (in Russian).

${ }^{11}$ Serebrovskii, A. S. (1929) Antropogenetika $i$ evgenika v sotcialisticheskom obshchestve [Anthropogenetics and eugenics in a socialist society]. Med.-biol. zhurn., vyp. 5, pp. 3-19. (in Russian). 
has discredited this scientific direction, and now eugenics is already the past. However, the best of her legacy, the goals set before eugenics by her founders and not achieved by her, became the subject of medical genetics and is currently used by her in particular cases to control hereditary changes during the development of a child with the aim of elimination or reduction of morbidity, disability and mortality, providing the necessary quality of human life in accordance with its genotype $^{12}$.

\section{A. Serebrovskyi's contribution to the formation of the genetic basis of farm animal selection}

It is known that in the early years of A. Serebrovskyi in the house of his father, the Tula architect, there were often future leaders of the Bolshevik party, including A. Lunacharskyi and others. There is reason to believe that the pro-revolutionary the orientation of the Serebrovskyi family further facilitated his administrative growth and the scale of his ideas on transforming livestock was supported by party leaders. So, in the context of the search for new ways of introducing genetic knowledge into agricultural production, the Board of the People's Commissariat of the USSR in 1931 adopted a resolution on the wide development of the large-scale work proposed by A. Serebrovskyi and F. Liskun on remote hybridization of animals. It was planned to obtain and study hybrids of cattle with yak, zebu, banteng, guayal, bison, production of hybrids of sheep and pigs with wild species, hybrids of various species of geese, ducks. It was also planned to study the possibilities of distant hybridization (cows with buffalo, reindeer with other species of deer, etc.) and restore the fertility of barren hybrids.

Considering the facts of natural hybridization of species in nature, A. Serebrovskyi analyzed the world hybridization resources and made a successful attempt to classify them. In 1933, he published the article "Animal Hybridization as a Science", , in which he first outlined the

\footnotetext{
${ }^{12}$ Gershenzon, S. M., \& Buzhievskaia, T. N. (1996) Evgenika: 100 let spustia [Eugenics: 100 years later]. Chelovek, no. 1, pp. 16-24. (in Russian).

${ }^{13}$ Serebrovskii, A. S. (1933) Gibridizatciia zhivotnykh kak nauka [Hybridization of animals as a science]. Tr. In-ta po gibridizatcii $i$ akklimatizatcii s. $k h$. zhivotnykh $v$ Askanii-Nova, vol. 1, pp. 20-32. (in Russian).
} 
content and program of his proposed science on controlling hybridization processes, and in 1935 his monograph "Animal Hybridization" was published, containing many interesting ideas and considerations that are relevant for modernity, and until recently, remained the only one in Russian literature ${ }^{14}$. It was the solution to hybridization problems that contributed to the short-term period of A. Serebrovskyi's work in Ukraine, in the world-famous Askania-Nova Nature Reserve. Unfortunately, from this large and valuable hybridization program, much less than planned was implemented.

In 1933, A.S. Serebrovskyi was elected a corresponding member of the Academy of Sciences of the USSR, and in 1935 - Academician of the All-Union Academy of Agricultural Sciences, where he temporarily headed the department of animal husbandry. He began to argue that urgent and widespread use of genetic methods in animal breeding. His specific proposals were radical and provoked an angry confrontation between livestock breeders, as Serebrovskyi's radicalism was in sharp contradiction with the centuries-old and very thoughtful practice of breeding.

Assessing the great contribution of A.S. Serebrovskyi to the theory and practice of animal technology, one should not forget that he, like most then geneticists of the classical direction, was mistakenly convinced that there was no influence of environmental conditions on heredity. This fundamental error probably comes from the fact that geneticists-experimenters of those years, working mainly with a microscope and laboratory Drosophila lines or plant tissue cultures under fairly stable laboratory conditions, did not record any visible hereditary changes. Anthropogenic pollution of the environment was then very insignificant. And genetics, with all their vital energy and individual courage, defended their point of view. At the same time, breeders-breeders, having everyday practice of both positive and negative influence of factors of feeding and keeping the animal on the realization of his hereditary inclinations, sincerely could not understand the intransigence of geneticists. This contradiction became so acute that it further contributed to the development of tragic events for genetics in the 1930's-1950's. Unfortunately, in those years, neither the supporters

${ }^{14}$ Serebrovskii, A. S. (1935). Gibridizatciia zhivotnykh [Hybridization of animals]. M.-L., 290 s. (in Russian). 
of the chromosomal theory, nor the breeders still understood that it was not the acquired characters that were inherited, but the genetically determined rate of the body's reaction to the newly created environmental conditions. This methodological error for almost 40 years hindered the integration of the two trends in genetics into a synthetic genetic theory.

I would like to illustrate this contradiction by the example of the scientific disputes of A.S. Serebrovskyi and M.F. Ivanov, who from 1930 to 1935 were scientific consultants at the All-Union Institute of Animal Hybridization and Acclimatization of Askania-Nova. It so happened that their names became the personification of two areas in zootechnical science, the contrast of which since the midle1930's has acquired an ideological coloring.

The authority of M. Ivanov among breeders and especially livestock breeders was extremely high due to the creation of two breeds according to the technique developed by him in less than 10 years. A.S. Serebrovskyi, fascinated by the idea of introducing genetic methods into breeding, developed a new system of pedigree work in the breed, based on which he put forward the leader theory put forward by him in those years with the identification of improvement producers and the indispensable use of artificial insemination. Both M. Ivanov and A. Serebrovskyi, both with great respect for each other, but gave different emphasis to selection methods. Ivanov, as a practitionerbreeder, made extensive use of individual selection and phenotype selection at different stages of breed breeding, without detracting from the importance of evaluating animals by genotype. He believed that thus, under those specific conditions, in a short period of time, a new highly productive breed could be bred. A. Serebrovskyi criticized the phenotype assessment method in his speeches, arguing that the phenotype of a genetically valuable leader is not of fundamental importance, and also denied the importance of feeding conditions and keeping the leader to realize its genetic potential. Subsequently, he selfcritically admitted underestimation of this method.

As in many other areas, the recommendations of A.S. Serebrovskyi only came to fruition in the last decades, when conditions were created for large-scale breeding in the breed using on a large array of uterus of producers, evaluated by the quality of their breeding. Of particular note is his prediction of the need for these conditions of a 
strict genetic analysis of producers for the carriage of lethal and defective genes, translocations, etc.

Of course, after almost a century, the fundamental significance of the genetic discoveries of the 1900-1930's. It seems obvious, but we must not forget that from the time of J.B. Lamarck until the 1970's, the theory of inheritance of acquired attributes under the influence of the external environment steadily functioned. It was this theory that provided a huge range for initiative in a targeted alteration of the nature of the heredity of plants, animals, and humans in the desired direction. The chromosome theory did not create such "convenient" possibilities. Moreover, unfortunately, until the 1960s, even in genetics textbooks, a list of conditions under which open genetic laws were observed was not clearly stated. Most geneticists, these laws are simply absolutized.

Already in the early 1930's, it became apparent that biology, especially genetics, is closer to other human sciences to the humanities, the basis of which was party affiliation. It is biology that adjoins a complex of agronomic and zootechnical sciences, from which they expected the salvation of the country's national economy, destroyed during the civil war.

In 1932, the All-Union Conference on the Planning of Breeding and Genetic Research was held in Leningrad, at which A.S. Serebrovskyi was elected deputy chairman. Those were the years of active development of the Stalinist plan for the continuous collectivization of agriculture and the industrialization of heavy industry. New approaches to solving these global problems were required. Under these conditions, the fate of geneticists was made dependent on success in the practice of agricultural production. However, N. Vavilov in his report set very large, implausible volumes of tasks. These were global tasks of a strategic, but not tactical nature in the conditions of those difficult years.

The development plan of genetics, presented by A.S. Serebrovskyi, was distinguished by even more significant unreality ${ }^{15}$. During the most important works on artificial insemination of cattle, he had in mind the

${ }^{15}$ Serebrovskii, A. S. (1933) Zadachi genetiki vo vtoroi piatiletke $v$ sviazi $s$ problemami zhivotnovodstva [The tasks of genetics in the second five-year period in connection with the problems of animal husbandry]. Tr. Vsesoiuz. konf. po planirovaniiu genet.-selektc. issled., Leningrad, 25-29 iiunia 1932 g. Leningrad, pp. 46-63. (in Russian). 
replacement of natural sperm with artificial sperm. He intended to provide "a reduction in generational change by growing gonads in adult animals or in tissue cultures." Thus, in those distant 1930's, they anticipated the achievements of modern biotechnology of animal reproduction. Moreover, even such completely unrealistic problems as "obtaining mutations such as polyploidy in domestic animals were included in the five-year plan. Of course, in that period of a tough command-administrative style of managing the national economy, a total search for more and more new ones" enemies of the people, there really was such a call, but the answer was unsatisfactory.

The leaders of Russian genetics, unfortunately, did not immediately realize that, given the specifics of the attitude of the authorities towards science, which had reigned firmly in the Soviet Union since the second half of the 1930's, even the simplest lag in terms, not to mention the failure to fulfill the tasks of the practical implementation of the stated scientific obligations was absolutely unacceptable. Assessing the complexity of the relationship in the struggle between two directions in the genetics of that period Michurin-Lysenko and classical, it becomes obvious that the failure of the promises made by N.I. Vavilov and A. S. Serebrovskyi for the fiveyear period 1932-1937, significantly undermined the faith of the Soviet government in the strength and capabilities of genetics, while strengthening the position of T.D. Lysenko.

The national economy of the USSR of those years, with its many millions of illiterate population, required simple, affordable and reliable methods to increase crop yields and productivity of domestic animals. Lysenko was able to convince the Soviet people, led by the top government, in the "obvious simplicity" of obtaining these seemingly impossible results. The methods proposed by the agricultural technician were accessible to understanding both collective farm breeder practitioners and party leaders who provided ideological and economic support to T.D. Lysenko and the direction he led in biological science.

So, in the middle 1930's, Stalin relied on Lysenko and with from that moment pressure, in various forms, on biologists and, above all, on geneticists, did not stop. At first, in 1935-1936, a scientific discussion tightly controlled by the party leadership was launched. Its culmination was the IV session of the Supreme Agricultural Academy (December 19-27, 1936), the main theme of which was "The controversial issues of genetics 
and selection." The main speakers here were N. Vavilov, T. Lysenko, G. Meller, A. Serebrovsky and N. Dubinin. At this session, what was subsequently called Lysenko clearly took shape. The session was preceded by a series of arrests of scientists and administrators of science.

Since the middle 1930's, and over the next 30 years, differences in understanding the influence of environmental factors on the formation of heredity have been the scene of not only scientific disputes. Due to the specificity of the personality of T. Lysenko and a number of his associates, scientific discussions were transferred to the rails of ideological struggle, using such favorite attributes of the dictatorship of the Soviet government of that time as exposing "enemies of the people" with the active involvement.

At the beginning of 1937, after the Academy session, A.S. Serebrovskyi left the UIAH, since working conditions on the theoretical foundations of genetics and selection because of fundamental methodological differences with the leadership became impossible here. During this period, the eugenic views of A.S. Serebrovskyi expressed by him in the late 1920's began to play a negative role. The next round of bloody Stalinist repressions began, the organization of the total surveillance of many scientists. These were periods of continuous demonstrative political processes. A similar political process was outlined in biological science.

The resistance of the geneticists at the 1936 session was not broken, and the next wave of various measures to suppress science ended in the fall of 1939 with a public discussion (in the press it was called the "Conference on Genetics and Breeding") in Moscow under the auspices of the journal Under the Banner of Marxism. Now the leadership of the party and government has moved from a scientific discussion to an ideological one, thereby sharply limiting the possibilities of opponents of T. Lysenko. Lysenko himself, among other posts, was appointed to the post of director of the Institute of Genetics of the USSR Academy of Sciences, taking the place of the arrested N. Vavilov. At that time, many major professors of genetics were arrested. However, the final defeat of the classical genetics in that period still failed. The Great Patriotic War began, and then the period of restoration of the national economy.

After leaving the UIAH, A.S. Serebrovskyi concentrated all his efforts on pedagogical and scientific work at the Department of Genetics of Moscow State University, where he studied problems such as gene 
theory, the laws of the mutation process, and genetic methods of controlling harmful insects. In the same period, Serebrovsky summed up his many years of analytical studies of the most complex evolutionary problems, such as the orientation in the development of individual taxa, parallelism in the phylogenesis of similar forms, the uneven evolution of various groups and some other issues in the book "Some Problems of Organic Evolution" completed by him in 1939. However, this outstanding work was published only in 1973 and, moreover, does not contain the full volume of material written by A. Serebrovskyi ${ }^{16}$.

In 1940, A. Serebrovskyi published an article with the main principles of the method of using x-ray radiation to control harmful insects by sterilizing males due to the induction of chromosomal rearrangements ${ }^{17}$. A detailed theoretical justification of this method and determination of quantitative characteristics were carried out at the department before the start of the war, then in Ashgabat, where the university was evacuated, and after the Moscow State University returned to Moscow. A.S. Serebrovskyi was the only scientist who took with him to evacuate living material from his work. An aquarium with test tubes and flies was placed on the train instead of a suitcase with his family's belongings.

As often happens with similar works, the idea did not find a positive response in his native country and foreign geneticists took advantage of A. Serebrovsky's developments, successfully introducing them into practice. And only much later, in order to restore historical justice, his first article was translated and published in English in 1969 and two years later the fundamental work on this issue, prepared by A. Serebrovskyi himself shortly before his death out of print ${ }^{18}$.

In 1945, learning about the death of his beloved daughter Alexandra, the heiress of his ideas, just two weeks before the end of the war, she fell ill. However, he continued intensive pedagogical and scientific work at Moscow State University. Over the years,

16 Serebrovskii, A. S. (1973) Nekotorye problemy organicheskoi evoliutcii [Some problems of organic evolution]. Moscow, 168 s. (in Russian).

17 Serebrovskii, A. S. (1940). O novom vozmozhnom metode borby s vrednymi nasekomymi [About a new possible method of combating harmful insects]. Zool. zhurn. vol. 19, vyp. 4, pp. 618-630. (in Russian).

${ }^{18}$ Serebrovskii, A. S. (1971) Teoreticheskie osnovaniia translokatcionnogo metoda borby s vrednymi nasekomymi [The theoretical basis of the translocation method of controlling harmful insects]. Moscow, 87 s. (in Russian). 
A.S. Serebrovskyi completed the monograph "Selection of animals and plants", but already at the stage of layout the book was removed from print and its set was scattered. The capital work Genetic Analysis, on which A. Serebrovskyi had been working since 1925, suffered the same fate. He was very worried about this attitude to his work and the intrigue around genetics on the part of Lysenko, strokes followed one after another. In March 1947, the Department of Genetics of Moscow State University, which was constantly led by A.S. Serebrovskyi, held a genetic conference. It was, in essence, a report on the enormous work done. No one could have thought that this conference would be the last and that work in this direction would resume only decades later. Due to a serious illness, he himself was able to attend only one meeting.

A new round of Stalinist repressions of 1947-1952 contributed to the final elimination of genetics as a science. The August session of the All-Union Agricultural Academy of Agricultural Sciences of 1948 "On the Situation in Biological Science" played a significant and monstrous role in its scope and form: the session proclaimed an official ban on normal scientific genetics and selection in the country with rich scientific traditions. Agricultural science was hit, as a result, from which it was never able to recover - once after that, biological and especially genetic theory in domestic agriculture did not rise to such heights as in the 1920-1930's.

The defeat of genetics, initiated by the August session of the Higher Academy of Agricultural Sciences, mined A. Serebrovskyi: on June 26, 1948, he died. The scientist passed away at the height of his intellectual powers, one of the last representatives of the national biological school of the period of her highest flight, one of the few representatives who survived in the 1930's, survived in the 1940's and did not fall in 1950's and later, - one of those who did not give up, "did not disarm" as they used to talk about N. Koltsov, N. Vavilov, A. Serebrovsky.

In the autumn of 1940, at the 69th year of his life, N. Koltsov died of a heart attack. A 56-year-old A. Serebrovskyi died of another stroke a month before the opening of the August session of 1948. In 1951, N. Vavilov, president of the USSR Academy of Sciences, died, not having lived a few weeks before 60 , and exactly 8 years after the death of his brother, who died of starvation in a Saratov prison. 
These and many other people of that time during the last years of their lives lived not only under constant fear of physical reprisal, they lived in conditions of terrible, in their destructive power, moral repressions. Then it turned out that those who feared for their lives almost always lost their honor and dignity, who completely defended their dignity and honor - often lost their lives. And not necessarily under execution or in dungeons. Death was overtaken simply when the obsolete human organism was no longer able to withstand such inhuman emotional stress under the ever-increasing psychological pressure of the surrounding society.

\section{CONCLUSION}

Summing up the scientific work of A. Serebrovskyi, we can confidently say that in many issues of science and practice he was ahead of events by more than 50 years. So, he actively raised the question of the use of artificial insemination of farm animals in large-scale breeding conditions, revealed the prospects of using methods of culturing embryos and other techniques in animal husbandry, which only recently have been embodied in biotechnological science. For the contribution of the evolutionary ideas his work in this area, he was named among the founders of the synthetic theory of evolution, created decades after his death. A. Serebrovskyi's genogeographic ideas in the field of population genetic analysis still remain unfulfilled. His proposed translocation method of controlling harmful insects, misunderstood and rejected in the 1940's, subsequently received widespread recognition and used all over the world. A. Serebrovskyi laid the foundation for modern ideas about the structure of the gene, and his idea of duplication of genes as a factor in progressive evolution was reflected and developed in the modern science of the evolution of proteins. The phenomenon of the "burden of mutations", to which G. Meller drew attention to the end of his life and introduced this term, was almost 30 years earlier indicated by A. Serebrovskyi in the same words. His ideas about artificial insemination of people have long become the norm of medical genetics. A scientific school of A. Serebrovskyi has dozens of brilliant researchers in the field of general genetics, genetics and animal breeding. In the end, we would like to note that the scientific heritage of this outstanding scientist of the 20th century, which was largely undeservedly forgotten by the descendant, deserves a closer study and can serve as the basis for discovering new pages of genetics. 


\section{SUMMARY}

Achievements of modern molecular genetics, technology of cloning organisms, DNA technologies are largely associated with significant theoretical and practical work of domestic geneticists of the 1920-1940's. Among intellectual elite a significant role belongs to A.S. Serebrovskyi - one of the prominent Soviet geneticists, whose creative heritage was intensely ignored in the first, and was largely not appreciated in the second half of the last century.

The purpose of this article in the context of historical events associated with the development of domestic and world genetics during the first half of the 20th century is to present biographical data that highlights the life and fate of the famous geneticist A.S. Serebrovskyi in science; and also consider his contribution to genetics and, in general, to biological science, focusing on the scale of his ideas, its perception by contemporaries of the scientist and the significance of these ideas for our time.

He actively raised the question of the use of artificial insemination of farm animals in large-scale breeding conditions, revealed the prospects of using methods of culturing embryos and other techniques in animal husbandry, which only recently have been embodied in biotechnological science. He was named among the founders of the synthetic theory of evolution, created decades after his death. Serebrovsky's genogeographic ideas in the field of population genetic analysis still remain unfulfilled. His proposed translocation method of controlling harmful insects, misunderstood and rejected in the 1940's, subsequently received widespread recognition and used all over the world. A. Serebrovskyi laid the foundation for modern ideas about the structure of the gene, and his idea of duplication of genes as a factor in progressive evolution was reflected and developed in the modern science of the evolution of proteins. The general scientific and interdisciplinary methods used to solve research tasks. Particular attention paid to special historical methods, source analysis. The source base of the research includes a complex of diverse documents, the basis of which are archival materials.

\section{REFERENCES}

1. Aslanian, M. M., Varshaver, N. B., \& Glotov, N. V. (1993) Aleksandr Sergeevich Serebrovskii [Aleksandr Sergeevich Serebrovskii]. Moscow, 192 s. (in Russian). 
2. Bezzubtcev-Kondakov, A. (2003) Evgenika kak "prokliatyi vopros" XX veka. Za [Eugenics as a "damned question" of the $20^{\text {th }}$ century]. Russkoe delo, no. 4 (106), pp. 12-24. (in Russian).

3. Vavilov, Yu. N. (1997) Pismo Germana Mellera I.V. Stalinu [Letter from German Meller I.V. to Stalin]. Voprosy istorii estestvoznaniia i tekhniki, no. 1, pp. 24-32. (in Russian).

4. Vavilov, Yu. N. (1998) Avgust 1948. Predystoriia [August 1948. Background]. Chelovek, no. 3, pp. 8-38. (in Russian).

5. Gershenzon, S. M., \& Buzhievskaia, T. N. (1996) Evgenika: 100 let spustia [Eugenics: 100 years later]. Chelovek, no. 1, pp. 16-24. (in Russian).

6. Dubinin, N. P. (1973) Vechnoe dvizhenie [Perpetual motion]. Moscow, 446 s. (in Russian).

7. Rychkov, Yu. G., Zhukova, O. V., \& Evsiukov, A. N. (2001). Genofond $i$ genogeografiia narodonaseleniia [The gene pool and population genogeography]. SPb, vol. 1,611 s. (in Russian).

8. Serebrovskii, A. S. (1919) Izuchenie nasledstvennosti selskokhoziaistvennykh zhivotnykh [The study of the heredity of farm animals]. Trudovoe khoz-vo, no. 5, pp. 19-20. (in Russian).

9. Serebrovskii, A. S. (1921) O mendelirovanii mnogoplodiia $u$ cheloveka [On the manifold of multiple pregnancy in humans]. Izv. In-ta eksperim. biologii, vyp. 1, pp. 114-119. (in Russian).

10. Serebrovskii, A.S. (1926) Genetika domashnei kuritcy [Genetics of domestic chicken]. Tr. Anikov. genet. stantcii. Moscow: Novaia derevnia, vyp. 1, 137 s. (in Russian).

11. Serebrovskii, A.S. (1928). Problema gena i ego izmerenie [The problem of the gene and its measurement]. Tr. Vseros. sezda zoologov, anatomov i gistologov, Leningrad, 14-20 dek., p. 51. (in Russian).

12. Serebrovskii, A. S., \& Dubinin, N. P. (1929). Iskusstvennoe poluchenie mutatcii i problema gena [Artificial mutation and gene problem]. Uspekhi eksperim. biologii. Ser. Biologiia, vol. 8, vyp. 4, pp. 235-247. (in Russian).

13. Serebrovskii, A.S. (1929) Antropogenetika $i$ evgenika $v$ sotcialisticheskom obshchestve [Anthropogenetics and eugenics in a socialist society]. Med.-biol. zhurn., vyp. 5, pp. 3-19. (in Russian).

14. Serebrovskii, A.S. (1960) Pismo v redaktciiu [Letter to the editors]. Med.-biol. zhurn. vyp. 4/5, pp. 447-448. (in Russian).

15. Serebrovskii, A. S. (1933) Zadachi genetiki vo vtoroi piatiletke $v$ sviazi s problemami zhivotnovodstva [The tasks of genetics in the 
second five-year period in connection with the problems of animal husbandry]. Tr. Vsesoiuz. konf. po planirovaniiu genet.-selektc. issled., Leningrad, 25-29 iiunia 1932 g. Leningrad, pp. 46-63. (in Russian).

16. Serebrovskii, A. S. (1933) Gibridizatciia zhivotnykh kak nauka [Hybridization of animals as a science]. Tr. In-ta po gibridizatcii $i$ akklimatizatcii s.-kh. zhivotnykh v Askanii-Nova, vol. 1, pp. 20-32. (in Russian).

17. Serebrovskii, A. S. (1935). Gibridizatciia zhivotnykh [Hybridization of animals]. M.-L., 290 s. (in Russian).

18. Serebrovskii, A.S. (1940). O novom vozmozhnom metode borby $s$ vrednymi nasekomymi [About a new possible method of combating harmful insects]. Zool. zhurn. vol., 19, vyp. 4, pp. 618-630. (in Russian).

19. Serebrovskii, A.S. (1969). Selektciia zhivotnykh $i$ rastenii [Selection of animals and plants]. Moscow, 295 s. (in Russian).

20. Serebrovskii, A. S. (1970) Geneticheskii analiz [Genetic analysis]. Moscow, 342 s. (in Russian).

21. Serebrovskii, A.S. (1971) Teoreticheskie osnovaniia translokatcionnogo metoda borby $s$ vrednymi nasekomymi [The theoretical basis of the translocation method of controlling harmful insects]. Moscow, 87 s. (in Russian).

22. Serebrovskii, A. S. (1973) Biologicheskie progulki [Biological walks]. 3-e izd., sokr. Moscow, 68 s. (in Russian).

23. Serebrovskii, A. S. (1973) Nekotorye problemy organicheskoi evoliutcii [Some problems of organic evolution]. Moscow, $168 \mathrm{~s}$. (in Russian).

24. Soifer, V. (2004). Zagublennyi talant (Istoriia zhizni odnogo laureata) [Ruined talent (Life story of one laureate)]. Vashington, 415 s. (in Russian).

\section{Information about the author: \\ Roman Bey,}

Doctor of Historical Sciences, Senior Researcher, Chief Scientist of the Scientific Bibliography and Biography Study of the National Scientific Agricultural Library of NAAS

10, Heroiv Oborony str., Kyiv, 03127, Ukraine ORCID ID: orcid.org/0000-0003-0649-2141 


\section{LEADING TRENDS OF AGRICULTURAL EDUCATION DEVELOPMENT IN THE $19^{\text {TH }}$ - AT THE BEGINNING OF THE 20 ${ }^{\text {TH }}$ CENTURY}

\section{Svetlana Hordenko}

\section{INTRODUCTION}

During the period of Ukrainian entry into the pan-European educational space, for the cardinal renewal of education, it is necessary to take into account not only the realities and prospects of the socioeconomic development of the country, the educational experience of the developed countries, but also its own historical path. It is a multifaceted analysis of the experience gained over the years of the historical development of higher agricultural education that will help predict the tendencies and prospects for its further development.

Higher agricultural education has a history that is inextricably linked to its political, economic, social and cultural life.

Agronomy is an ancient science about agriculture. However, its theoretical foundations were formed only in the second half of the nineteenth century, and only in the late nineteenth and early twentieth centuries was a process of formation of narrow-branch scientific disciplines. The value of science is measured by how much it benefits people. The development of agricultural science has always been closely linked to the needs of human society.

Particular interest is for the period of the nineteenth and early twentieth centuries, when under the influence of changes in the sociopolitical, socioeconomic and cultural life of the Russian Empire, which included a large part of the Ukrainian lands, there was an intensive development of the educational system, the organic component of which was agricultural also. Significant achievements in the field of agriculture during that period led to the formation and development of multi-level agricultural educational institutions: schools, classes, courses, colleges. In turn, lower and secondary education in this field contributed to the establishment of the first agrarian higher educational establishments and to increase the professional level of training of teachers of agricultural disciplines, 
which positively affected the quality of activity of specialists of the agro-industrial complex of Ukraine.

Through the prism of the history of European universities, we can outline the process of development of science and education in Ukraine. First of all - these are the origins, prerequisites, patterns, and features of the initial period.

In this regard, it is important to summarize and study the problem of studying the historical and pedagogical values of the system of higher agrarian education of Ukraine in the nineteenth and early twentieth centuries.

\section{Development of agronomic knowledge in the world $\left(19^{\text {th }}\right.$ - the beginning of of the $20^{\text {th }}$ century)}

The cultural rise and economic development of European countries have contributed to the dissemination of scientific agronomic knowledge. Ever since agriculture has become an important science, there has been a need to disseminate and improve this scientific knowledge.

In the second half of the nineteenth century, the theoretical direction of agricultural education, which provided teaching at universities, was widely developed. Many European universities have set up separate agricultural departments or separate institutes. Scientific and educational activities of the university agronomy departments contributed to the emergence of new professional educational institutions. However, despite the parallel existence of two trends in the development of professional agricultural education: a significant number of professional educational institutions and agrarian courses at universities - till the beginning of the twentieth century the final program of a planned development of the agrarian education system has not yet been drawn up in European countries ${ }^{1}$.

Earlier than in other European countries, the formation of agricultural education took place in Germany. The development of agricultural education at universities in Germany had two stages. The

1 Kostenko O. O. (2004) Universytety XIX st. ta poshyrennia naukovykh ahronomichnykh znan u Yevropi [XIX century universities and the dissemination of agronomic knowledge in Europe]. Proceedings of the Materialy druhoho mizhrehionalnoho naukovo-praktychnoho seminaru molodykh vchenykh, (Luhansk, serpen 27-28, 2004), Luhansk, pp. 32-36. 
initial stage began in the first half of the eighteenth century. Then, along with the university sciences, a course in agriculture was introduced into the German School of Economics.

During the $18^{\text {th }}$ century, similar departments have been created in almost all other universities in Germany. Agronomy courses have been taught at many German universities ${ }^{2}$.

The first attempts to introduce systematic special agricultural education were made by the creator of agricultural science A. Thaer, who was aware of the importance of professional education for the development of agricultural theory. Scientist opens agricultural school in Meglin (near Berlin) for persons belonging to the state of hereditary landowners.

As Professor Goltz noted in the History of German Agriculture, the estate at the Meglins Academy, under Thaer, he served not so much for students' practical classes as for demonstrative confirmation of agricultural knowledge and for the scientific experience. The most important practical institution at the Academy immediately obeyed the main task - the theoretical study of agriculture and the organization of scientific research in this field. The Prussian government, in his lifetime, appreciated the merits of A. Thaer, he was awarded the title of secret advisor. The Meglin School was given the title of Royal Agricultural Academy and also assigned to A. Thaer financial support and the professors' wages were paid to the state ${ }^{3}$.

The Prussian King Friedrich-Wilhelm III, by decree of July 1, 1805, tried to establish separate institutes for teaching agriculture at universities. At the universities, the departments of agronomy were attached to the physics and mathematics departments of the faculties of philosophy. The Meglin Academy remained for a long time the only agricultural school of Prussia. Following the Meglin Academy - the first higher agricultural school of "practical" type - other German

2 Krtsimovskiy R. (1927) Razvitie osnovnykh printsipov nauki o sel'skom khozyaystve $v$ Zapadnoy Evrope [Development of the basic principles of agricultural science in Western Europe]. Moskva: Novyy agronom. (in Russian)

3 Veshnyakov V. (1866) Obzor sel'skokhozyaystvennykh uchrezhdeniy v Anglii, Frantsii, Bel'gii, Gollandii, Germanii $i$ Italii [Overview of agricultural institutions in England, France, Belgium, Holland, Germany and Italy]. Sankt-Peterburg. (in Russian) 
agricultural academies were founded: in Hohenheim and Idstein (1818), in Schlesheim (1822), in Yen (1826), in Taranda - (1829), Elden (1835), in Regenwald - (1842). In the 40-50s of the 19th century agronomic academies were established in Proskau (1847); in Poppelsdorf (1847); in Weeden (1851) and in Waldau (1858). Most of the academies were independent agricultural institutes not directly affiliated with universities.

In 1818, a well-known French agronomist Mathieu de Dombale opened a similar school in Rowle (department of Meurthe, France). The Meglinsk and Roville schools gave agricultural education an independent movement, which halted the development of this science at universities for a long time. Almost all the higher agricultural and educational establishments, subsequently established in Germany and France, were independent.

The teaching of agricultural sciences was not only the property of special educational institutions. Often it was part of the educational system of special technical or general higher European schools. Thus, the agricultural course was taught at some European universities, at special institutions as polytechnic institutes and industrial-craft schools.

An example of the theoretical stage in the development of agricultural education in Germany was the creation of appropriate educational institutions at universities. Thus, in 1835, at the Greifswald University, an agronomic academy was opened in the Elden estate ${ }^{4}$.

The institute's activity was based on the principle of close communication between the agricultural school and the university. The same principle that subsequently formed the basis of the activity of the talented Yu. Liebig. The Academy replaced the Faculty of Commerce for the university, its purpose was to train not only future masters but also officials. According to contemporaries, no higher education institution in Germany had fuller teaching of agricultural sciences.

Following the example of the Elden Academy at the University of Bonn in 1847, another higher specialized educational institution was opened - the Poppelsdorf Academy. Initially, all of her teaching aids

\footnotetext{
${ }^{4}$ Meshcherskiy I. I. (1893) Vysshee sel'skokhozyaystvennoe obrazovanie v Rossii $i$ za granitsey [Higher agricultural education in Russia and abroad]. Sankt-Peterburg. (in Russian)
} 
were limited to the University of Bonn. In the future, the educational institution became completely independent ${ }^{5}$.

Apart from the agronomic academies, which were set up entirely on their own, as in Proskau and Waldau, or thanks to the agricultural activities of universities, as in Elden and Poppelsdorf, agricultural teaching continued at universities, such as Berlin and Gallen.

The famous German scientist J. Liebich has severely criticized isolated agricultural schools. In his works: "Letters on Chemistry" (1855), "On the Impact of the Sciences on the Development of the Welfare of the Population"(1861), and "Chemistry in Addition to Agriculture and Plant Physiology" (1863), he openly opposed the isolated position of agricultural academies. Yes, he noted: "Open ... modeled on the (Meglin) agricultural academies have done ... more harm than good. Separated from general education centers, they closed access to science, while the natural sciences since the time of Teyer have made a huge success. There is no special chemistry, no special physics, no special botany for the rural people, and therefore the need for agricultural education would be best met if it had links with universities"6.

The combination of higher agricultural education with practical institutions in exemplary farms was considered futile by J. Liebig. The scientist justified his views that the highest theoretical training and practice should go separately and independently from each other. J. Liebich's criticism of the autonomy and seclusion of agricultural education led to another turn in the development of the agricultural school and contributed to the combination of university and special agronomic education.

After the speech delivered by J. Liebig in 1861 at the opening of the Munich Academy of Agricultural Sciences, the process of opening agricultural institutes at the university accelerated.

For example, at the opening of the Prussian Agricultural Academy in Waldau, the Saxon Central Agricultural Society appealed to the government to organize the teaching of agriculture at the Gallic University, which resulted in the opening of the Department of Agriculture, where he

5 Veshnyakov V. (1866) Obzor sel'skokhozyaystvennykh uchrezhdeniy v Anglii, Frantsii, Bel'gii, Gollandii, Germanii $i$ Italii [Overview of agricultural institutions in England, France, Belgium, Holland, Germany and Italy]. Sankt-Peterburg. (in Russian)

${ }^{6}$ Krtsimovskiy R. (1927) Razvitie osnovnykh printsipov nauki o sel'skom khozyaystve $v$ Zapadnoy Evrope [Development of the basic principles of agricultural science in Western Europe]. Moskva: Novyy agronom. (in Russian) 
was appointed professor in 1863. Thus, in 1862, the full course of agricultural sciences was initiated at the University of Halle ${ }^{7}$.

Subsequently, assessing the 25-year activity of this department, A. Ye. Zaykevych wrote: "The teaching of agronomic sciences at the Gallic University not only subsided but achieved a brilliant development" ${ }^{\prime \prime}$. The department of agriculture has been expanded with the opening of several extra-curricular courses and associate professorates for teaching special agronomic disciplines. In the 9 years after the opening of the University of Gallen, he was the first in the number of students in agricultural schools in Germany.

The example of the Gallic University was taken over by other universities and opened agricultural institutes, namely: Leipzig (1869), Hesse (1871), Göttingen (1872), Kiel (1873), Kennigsberg (1876), Braslav (1881). All this gave rise to the formation of agricultural science at the universities of Germany, which helped to establish a solid foundation for the further development of agrarian science and research ${ }^{9}$.

There was a development of agricultural education, as well as with it in other European countries.

In the $50 \mathrm{~s}$ of the $19^{\text {th }}$ century, agricultural education has also developed in Austria. In this country, the higher agricultural institutions belonged to the Altenburg Institute in Hungary. Teaching agriculture was part of the program of the technical department of the Vienna Polytechnic Institute. Agricultural departments were established at the universities of Linz, Graz, Klagenfurt.

The issue of agronomic education was considered in the National Assembly of France, which ensured the adoption in 1848 of the law on agronomic education. Three degrees of agricultural education institutions were introduced. For the first time in university practice at

${ }^{7}$ Lebedintsev A. A., Shchusev S. V. (1894) Ustroystvo i deyatel'nost' opytnoy sel'skokhozyaystvennoy stantsii $\mathrm{V}$ «Galle» [The design and operation of the experimental agricultural station in Galle]. Vol. 4, pp. 12-28.

${ }^{8}$ Zaykevich A. E. (1891) Agronomiya kak nauka voobshche $i$ universitetskaya $v$ chastnosti [Agronomy as a science in general and university in particular]. Khar'kov: Tip. V. Biryukova. (in Ukrainian)

9 Veshnyakov V. (1866) Obzor sel'skokhozyaystvennykh uchrezhdeniy v Anglii, Frantsii, Bel'gii, Gollandii, Germanii $i$ Italii [Overview of agricultural institutions in England, France, Belgium, Holland, Germany and Italy]. Sankt-Peterburg. (in Russian) 
the Versailles National Agronomy Institute (1849-1852), it was suggested that the best graduates be sent abroad to improve their knowledge in order to further secure the institution with teachers.

In Belgium, since 1849, the government has considered the development of an agricultural education system. The issue was discussed in the chambers of the Belgian Parliament, which provided for an increase in public funds for agronomic education.

In Italy, in 1862, the Ministry of Agriculture hosted the following educational institutions: the Agricultural and Forest School in Turin, the Agricultural Institute in Cachin (near Florence), the Agricultural and Veterinary School in Pisa, the Agricultural Institute in Parma, the agronomic departments in the technical departments of the Technical Institute, Placentsk and Florentine ${ }^{10}$.

In addition, under the Ministry of Education, courses in agriculture at Turin, Naples, Bologna, Modena, Perugia, Palermo, Messina, Katan, Ferrara, Urbino, Macerata, and Cameroon. The agricultural course was taught mainly for students of engineering and borderland. But with the publication in the second half of the 60s in the 19th century, in Italy, the law on public education in agriculture was withdrawn from the programs of the university course (with the exception of the University of Turin).

In the UK, the organization of agricultural education was uneven in some parts of the kingdom. There was only one top-level agronomic institution in England directly in the Cirencester. It was founded on the initiative and at the expense of individuals until the end of the nineteenth century. did not use any financial resources from the government. There were no special education institutions in Scotland at all. But agronomic education subjects were taught at the University of Edinburgh and some other educational institutions. In Ireland, in contrast to England and Scotland in the mid-nineteenth century, there were numerous special educational institutions of the lower level ${ }^{11}$.

${ }^{10}$ Fausek V. (1897) Nekotorye nauchno-prikladnye uchrezhdeniya Ital'yanskogo ministerstva zemledeliya [Some scientific and applied institutions of the Italian Ministry of Agriculture]. Sankt-Peterburg. (in Russian)

${ }^{11}$ Benzin V. M. (1913) Organizatsiya sel'skokhozyaystvennogo obrazovaniya $i$ opytnogo dela $v$ Severo-Amerikanskikh Soedinennykh shtatakh i ee perspektivy $v$ Rossii [Organization of Agricultural Education and Experimental Affairs in the North American States and its Prospects in Russia]. Tambov: Tip. Gubernskogo zemstva. (in Russian) 
The idea of the need to combine higher education with scientific and practical training in the late nineteenth - early twentieth century has received support in all European countries. Model farms were everywhere replaced by research fields. Practical knowledge was gained through excursions to nearby advanced estates.

However, the scientific development of individual departments of the universities as part of a single national agricultural research. For example, according to the academician O. Sokolovskyi, in England in the 20 s of the twentieth century, research institutes of agrarian direction were created at higher general educational establishments universities, which were part of a single system of development of agrarian science. "The basis of the English scheme of agricultural research work was that each research institute developed a separate branch of agricultural science" $" 12$.

It is established that the first country where agriculture was recognized as a separate science was Germany. The success of German professional institutions was largely ensured by a high professional level of teaching staff. The Meglin Academy was bound by the success of renowned agricultural educator Teyer; Hohenheim Academy Schwartz, Weckerlin, Pabst; Elden Academy - Schultz; Poppelsdorf Garstein; Gallic Institute - Küne. All these are well-known agrarian scientists of the 19th century Germany. On the basis of their achievements in the field of agronomy, the first professors of domestic agricultural schools, including professors of Kharkiv University, subsequently built their programs.

\section{The state of domestic agricultural education in the universities of Ukraine (second half of $19^{\text {th }}$ - the beginning of the $20^{\text {th }}$ century)}

During the 19th - early 20th centuries, the Kharkiv region, like other Ukrainian lands, was part of the Russian Empire. Accordingly, the history of agricultural schools in Ukraine is closely linked to the development of agricultural education in Russia. In the history of agricultural education in modern Ukraine, the second half of the nineteenth and early twentieth centuries is a particularly important

12 Sokolovskyi O. (1895) Z podorozhuvannia do Anhlii: (naukovi zvity) [From a trip to England: (scientific reports)]. B.m., b.r. pp. 109-119. 
stage. During this period, the Ukrainian agricultural education achieved considerable success, gained valuable experience, which has not been studied for a long time and therefore underestimated ${ }^{13}$.

In the second half of the $19^{\text {th }}$ century were two main types of higher education agricultural institutions in Russia:

1) special educational institutions and 2) departments of agriculture at universities, other higher educational establishments.

In the 60 s of the $19^{\text {th }}$ century, the first type in the Russian Empire belonged to only 4 higher educational establishments that provided professional agricultural education: St. Petersburg Forest Institute (founded in 1848 in Gorky, reorganized in 1864), Petrovsk Agricultural Academy (opened in 1865) near Moscow), Riga Polytechnic College with the Department of Agriculture (opened in 1861), and the NovoAlexandria Institute of Agriculture and Forestry (reorganized in 1869). The former two were subordinated to the Ministry of State Property, the latter was subordinate to the Ministry of Public Education. The tasks of higher agricultural educational institutions were limited to the development of scientific questions of agriculture, the preparation of educated practitioners, able to conduct agricultural business in a qualified manner, to disseminate practical agronomic knowledge among the local population, to the training of teachers in various specialized agricultural disciplines for secondary schools ${ }^{14}$.

The formation of the entire education system was mainly influenced by the German higher education system. Higher education institutions were organized according to the German type, where they preferred the scientific rather than the practical side of teaching. But university agronomic education in Russia has not received this development.

Changes in agricultural life and nation-wide economic reforms in Russia required the appropriate extension and deepening of special agricultural knowledge, the introduction of professional education in

${ }^{13}$ Verhunov V. A. (2006) Narysy istorii ahrarnoi nauky, osvity ta tekhniky [Essays on the history of agricultural science, education and technology]. Kyiv: Ahrarna nauka. (in Ukrainian)

${ }^{14}$ Savel'ev A. Ya., Momot A. I., Khoteenkov V. F. (1995) Vysshee obrazovanie v Rossii: ocherk istorii do 1917 goda [Higher Education in Russia: A History Outline Before 1917]. Moskva: NII VO. (in Russian) 
the university course. At Moscow University, agricultural disciplines were taught following the example of European universities. In 1770-1777 the department of agriculture or agriculture was headed by M. I. Afonin, at the end of the $18^{\text {th }}$ century - A. A. AntonskyiProkopovych. Agricultural Sciences at Moscow University for 20 years (1820-1840) were taught by M. G. Pavlov ${ }^{15}$.

The teaching of agriculture at universities, other higher education institutions was conducted directly by the departments of agriculture (later agronomy) or agricultural departments (institutes) were created. At the beginning of the nineteenth century, university teaching of agriculture was conducted within the limits of the rural economy along with other branches of chamber science, sometimes together with technology (University of Derpt), with mineralogy (according to the charter of the Russian universities in 1804).

The development of agricultural education at university departments was regulated by legislative acts adopted by the Ministry of Public Education. The level of educational work of the university largely depended on the state of the teaching and support base: libraries, laboratories, offices, museums, and their availability to the states.

According to the order of November 5, 1804, in Moscow, Kharkiv, Kazan universities agricultural sciences were united together. Separate departments were created, known as "mineralogy and agriculture." These departments at the universities were equipped with appropriate offices and even laboratories and, of course, contributed to the development of agricultural science ${ }^{16}$.

The University Charter in 1863 reduced the teaching of agriculture to agronomic chemistry with the organization of relevant departments in the faculties of physics and mathematics. The charter of the universities in 1884 , the departments of agrochemistry were replaced by the departments of agronomy, which included general and private agriculture, agrochemistry, teaching about systems of farming and crop rotation.

15 Nikonov A. A. (1995) Nauchnye uchrezhdeniya i uchebnye zavedeniya sel'skokhozyaystvennogo profilya [Scientific and agricultural educational institutions]. Spiral' mnogovekovoy dramy: agrarnaya nauka i politika Rossii (XVIII - XX vv.). Moskva. pp. 112-120.

16 Morachevskiy V. V. (1914) Rasprostranenie sel'skokhozyaystvennykh znaniy [Agricultural extension]. Agronomicheskaya pomoshch'v Rossii. Petrograd. pp. 259-345. 
In the early twentieth century, a number of special agricultural educational establishments have already been established. However, the graduates of these educational institutions were not enough to solve the problems of scientific support of agricultural production, creation of research institutions. In 1908, the State Duma (representative legislative body in 1906-1917) indicated the need to increase the number of higher specialized educational establishments, to establish agronomic departments at universities and polytechnic institutes. It was suggested to consider the correspondence of study programs in higher educational institutions to the local economic conditions and agricultural needs of certain regions, in the center of which higher specialized educational establishments should be located as scientific, educational and methodical centers, that is, a plan was created for establishing a network of higher agricultural educational institutions in higher educational establishments: in each climate and economic region, eight new higher education institutions were to be opened, with two of them - in Ukrainian territories: in Katerynoslav and Odesa ${ }^{17}$.

In December 1910, the State Duma considered the question of establishing independent agronomic faculties at universities. At some Russian universities: Yurevsk, Kazan, Novorossiysk, and Kyiv agronomic departments (faculties) were actually created with special agronomic laboratories where future agronomists studied. But these faculties were few in number, and they existed for a limited time ${ }^{18}$.

Many prominent scientists worked at the departments of agriculture. For example, at Moscow University from 1894 to 1931 lectured D. N. Prianyshnykov. Since 1836, Professor S. M. Usov has taught agriculture, forestry, and accounting at St. Petersburg University. Later, Professor O. V. Sovietov, who was one of the first university agronomy teachers in Russia to create his own scientific school, worked at the reorganized department. In the process of teaching, the scientist involved the best students in experiments and observations in the field of agriculture. Subsequently, many of them devoted their lives to

${ }^{17}$ Smintin V. A. (2000) Istoriya Odes'kogo universitetu (1865-2000) [History of Odessa University (1865-2000)]. Odesa: AstroPrint. (in Ukrainian)

18 Bogdanov S. M. (1912) Voprosy sel'skokhozyaystvennogo obrazovaniya V spetsial'noy dumskoy komissii [Questions of agricultural education in a special Duma commission]. Khozyaystvo, no. 12, pp. 373-378. 
scientific agronomy and worked in Ukraine. The most famous figure among his students and followers is V. P. Budrin ${ }^{19}$.

Thus, it should be noted that rational staging of agricultural education was important for Ukrainian lands. Agrarian production was in direct connection with professional education. The level of agrarian production depended on the wide branching of the network of educational institutions, the development of narrow sciences and the implementation of measures to spread agrarian knowledge among the general population. The teaching of agricultural disciplines, like the name of the department itself, was constantly changing, which depended on the tasks assigned to the university departments.

Professor of Agronomy at Kharkiv University A. Ye. Zaikevych, analyzing the introduction of an agronomic course in university education as a supplement to the natural sciences, wrote that at the time of his teaching, this science was "devoid of its main elements: observation and experience, due to the weak development of science in time" ${ }^{\text {20 }}$. He explained the small scientific progress of agronomy in the first period of its development as a separate science.

According to the university statutes 1835, 1863, agricultural subjects were considered compulsory for all students in the natural science department. The task of teaching was to acquaint the students with the general principles of practical complement to the natural sciences: production and technical processing of agricultural productsii.

The unsatisfactory state of the science for teaching agricultural disciplines at universities, the need for their broader impact on local production, led many agrarian scientists to think of the creation of agronomic faculties or departments at universities in the German model.

The first to ask about the extension of the university course was Professor of Agronomy at Kharkiv University, V. A. Kochetov. At the 1st Moscow All-Russian Rural Congress in 1860, he proposed to extend the agronomic course to the establishment of departments at

19 Verhunov V. A., Kovalenko S. D. (2001) Profesor Budrin Petro Vasylovych (1857-1939): bibliohrafichnyi pokazhchyk naukovykh prats [Professor Budrin Petr Vasilievich (1857-1939): bibliographic index of scientific papers]. Kyiv: Ahrarna nauka. (in Ukrainian)

${ }^{20}$ Zaykevich A. E. (1891) Agronomiya kak nauka voobshche i universitetskaya $v$ chastnosti [Agronomy as a science in general and university in particular]. Khar'kov: Tip. V. Biryukova. (in Ukrainian) 
universities, that is, for the first time the question of extending the university course in Russia was raised almost simultaneously with the approval of university agronomic education in German government circles.

Ten years later, at the $4^{\text {th }}$ Congress of Naturalists and Physicians in Kyiv (1870) Professor of Agronomy at Novorossiysk University, D. N. Abashev submitted a project to expand the departments of agronomy, which was not only approved by the Faculty of Physics and Mathematics of this University, but was also approved at the Ministry of Public Education.

However, the statute in 1884 enshrined in the state of the university only one department of agronomic chemistry. This statute (1884), which was binding on all universities, introduced a new principle of teaching: for the purpose of greater specialization, the subjects of the university course were divided into general and special subjects. The former was compulsory for all students, the latter obligatory only for those who selected them as their specialty. Agronomic chemistry (or agronomy) belonged to the second group and together with technical chemistry formed a separate specialty.

Since then, agronomy has been regarded as an independent science. Some scientists, working on its definition, considering the nature of the object of her research, called this subject the biology and physiology of cultivated plants and animals. Thus, there was a process of differentiation of concepts: agriculture was attributed to industry, and the already existing university discipline providing scientific substantiation of agrarian production, in Russia was called agronomy ${ }^{21}$.

So agriculture as a discipline in the second half of the nineteenth century was called "agronomy". Agricultural courses were also taught at universities and other educational institutions. However, in the prerevolutionary period, the name of the scientific degrees: Master's and Doctor's degree of agriculture remained.

According to teachers of the late nineteenth century, agriculture as production depended on many factors, which they divided into two

${ }^{21}$ Melnychuk D. O., Zubets M. V. (2005) Stanovlennia i rozvytok ahrarnoi osvity ta nauky $v$ Ukraini ( $z$ naidavnishykh chasiv do sohodennia) [The formation and development of agricultural education and science in Ukraine (from ancient times to the present)]. Kyiv: NAU. (in Ukrainian) 
types. The first group consisted of physical factors, which included soil, climate, cultivated plants, and animals. The second group was formed by "social" factors: labor, capital, exchange, and distribution" ${ }^{22}$.

Considering the term "agricultural science", Professor of Kyiv University S. M. Bohdanov pointed to its dependence on the phenomena of nature and economy. The latest, in his opinion, led to the division of agronomy into two major departments: the technique of agriculture, meaning the doctrine of physical processes in agriculture, and ... the agricultural economy or economy, meaning the doctrine of the economic side of agricultural production"23.

S. M. Bohdanov believed that agronomy was an applied science, so it had to have a limited field of study, that is, to study only those economic and natural phenomena that were characteristic in the practice of agriculture in a particular region, but at the same time could be used indefinitely research methods of various fundamental, including natural sciences.

Gradually, agrarian scientists came to understand that the nature of the main factors of production determines the nature of basic agronomic sciences. So, the cultivation of the soil, which significantly affects the yield, required knowledge of mineralogy with geology and geognosy. Climate change, the ability to adapt to the natural and climatic conditions of the region required knowledge of meteorology with climatology. The doctrine of cultivated agricultural plants was based on knowledge of botany and plant physiology. The doctrine of breeding domestic animals led to the knowledge of the basics of zoology with animal physiology. The general scientific principles of agriculture required a deep knowledge of physics and chemistry. The social factors that led to the economic nature of agricultural production required knowledge of polytechnic economics (economics) and statistics. This was a list of basic sciences of agronomic courses which at the end of the $19^{\text {th }}$ century became or should be the subject of careful study at the university.

${ }^{22}$ Sazanov V. I. (1962) Sel'skokhozyaystvennoe opytnoe delo $v$ rastenievodstve $i$ ego metodika [Agricultural Experiment in Crop Production and its Methodology]. Moskva: Sel'khozizdat. (in Russian)

23 Bogdanov S. M. (1912) Voprosy sel'skokhozyaystvennogo obrazovaniya v spetsial'noy dumskoy komissii [Questions of agricultural education in a special Duma commission]. Khozyaystvo, no. 12, pp. 373-378. 
The issue of university agronomy also occupied a special place in the agronomy section of the $12^{\text {th }}$ Moscow Congress of Naturalists and Physicians, where reports were presented by A. N. Sabinin and D. N. Prianyshnykov. The resolutions of the congress stated: "To recognize the necessity and urgent increase of the centers of agronomic education", including "through the organization of agronomic departments at universities and higher technical educational establishments".

In addition, the importance of opening agronomic institutions in certain climatic regions of the country has become increasingly important. One of the first to support this was Professor of Novorossiysk University D. N. Abashev, who noted that for those who received a higher theoretical agricultural education, the importance of studying local economies. "Agricultural knowledge," the scientist said in a report at the $4^{\text {th }}$ Congress of Naturalists and Doctors in Kyiv, "is always ... local. For those who have received agricultural education in the north, after arriving in the south ... it takes a long time to learn ... completely new conditions ... Meanwhile, our two higher agricultural establishments are in the north" 24 .

In the future, this view was confirmed by Professor I. O. Shyrokykh, who, in denying D. N. Prianyshnykov at the 12th Congress of Naturalists and Doctors, said: "Agronomy has... another basic element: the process of agricultural production with an element is economy, so the development of agronomic departments at universities will respond favorably and at a special school, allowing it to give more resources to the master of studies" 25 .

The convenient geographical location of universities located in the Ukrainian lands, especially with regard to agricultural production, forced university professors of agriculture to recognize and uphold the idea that higher agronomic education should be given at universities and be territorially based.

${ }^{24}$ Savel'ev A. Ya., Momot A. I., Khoteenkov V. F. (1995) Vysshee obrazovanie v Rossii: ocherk istorii do 1917 goda [Higher Education in Russia: A History Outline Before 1917]. Moskva: NII VO. (in Russian)

${ }^{25}$ Zaykevich A. E. (1892) Agronomiya, kak nauka voobshche i universitetskaya v chastnosti [Agronomy as a science in general and university in particular]. Trudy vtorogo Kievskogo oblastnogo s'ezda [Proceedings of the Second Kiev Regional Congress]. Kiev: Tip. P. Barskogo, pp. 34-68. 
Thus, at the beginning of the twentieth century, the main tasks of the higher agricultural school were not only the acquisition of a certain cycle of scientific knowledge in the field of agriculture, the acquisition of certain skills of scientific research, but also acquaintance with some practical techniques and methods of agricultural technology in relation to local conditions. The question of extension of agricultural education at universities was raised, which, in turn, required the establishment of appropriate educational and support institutions.

With the approval of the university charter in 1835 , a separate subject was introduced into the course of Russian universities agriculture, which required the teaching of only a short encyclopedic course, which included information from various branches of agriculture. The charter of 1884 introduced the departments of agronomic chemistry (or agronomy). Since then, agronomy has been regarded as an independent science. However, the term "agronomy" included information from all branches of agricultural production and was essentially identified with the term "agriculture"26.

\section{CONCLUSIONS}

Advanced scientists understood the importance and advocated the extension of the agricultural course at domestic universities, which should serve not only to improve the system of special agricultural education but also to help raise the level of domestic agricultural production.

According to staffing, the name of the department, the volume, and the content of agricultural subjects changed, which was approved by the statutes of Russian universities. However, up to the revolutionary events, there was always one agrarian department at the physics and mathematics faculties of the universities.

From the above, it is clear that one of the important factors for the establishment of vocational education institutions was the rapid development of a market economy when production needed educated workers in the agricultural sector. The temporary differences in the rapid rise of agriculture in different parts of Europe have led to a

${ }^{26}$ Ferlyudin P. (1893) Istoricheskoe obozrenie mer po vysshemu obrazovaniyu $v$ Rossii [Historical Review of Higher Education Measures in Russia]. Saratov: Akademiya nauk i universitety. (in Russian) 
difference in the timing of national consolidation of national systems of special agricultural education.

European countries are characterized by the consolidation in the second half of the nineteenth century of a sustainable network of agricultural educational institutions. The agricultural faculties had European universities. In addition to university agronomy, there are separate specialized higher education institutions in European countries.

Favorable natural and geographical conditions, high fertility of land have historically determined the agrarian and economic character of the development of Ukrainian lands. At the same time, the issues of scientific support for agricultural production have always occupied an important place in the research work of the natural history departments of the first universities.

Universities opened in the Ukrainian territory of the Russian Empire in the pre-revolutionary period were part of the general education system. In the university course, all-Russian statutes enshrined the teaching of agricultural disciplines.

The training of agricultural specialists has gained the greatest development in the Ukrainian lands of Russia.

In the history of agricultural education development, the period of formation of domestic scientific and educational centers at universities was underestimated. However, in the second half of the nineteenth and early twentieth centuries, university departments achieved considerable success and gained valuable experience.

\section{SUMMARY}

The article shows the formation of agricultural science at universities in Germany, which helped to establish a solid foundation for the further development of agrarian science and research.

The development of agricultural education, as well as science in other European countries, is also covered.

It was established that on the basis of scientific achievements in the field of agronomy of German agrarian scientists 19th century, the first professors of domestic agricultural schools, including professors of Kharkiv University, subsequently built their programs.

In the course of the research it was found out that in the countries of Europe during the period (the second half of the nineteenth century) 
and in the Russian Empire (the beginning of the twentieth century) there were processes of state consolidation of the development of professional agricultural education and branch scientific centers of agrarian direction. Regional agricultural educational institutions included agronomic (agricultural) departments of universities.

Differentiation of concepts at domestic universities is shown, namely, that agriculture as a discipline in the second half of the nineteenth century was called agronomy, which was considered as an independent science. Higher agronomic education should be given at universities and be territorially based.

\section{REFERENCES}

1. Benzin V. M. (1913) Organizatsiya sel'skokhozyaystvennogo obrazovaniya i opytnogo dela $v$ Severo-Amerikanskikh Soedinennykh shtatakh $i$ ee perspektivy $v$ Rossii [Organization of Agricultural Education and Experimental Affairs in the North American States and its Prospects in Russia]. Tambov: Tip. Gubernskogo zemstva. (in Russian)

2. Bogdanov S. M. (1912) Voprosy sel'skokhozyaystvennogo obrazovaniya V spetsial'noy dumskoy komissii [Questions of agricultural education in a special Duma commission]. Khozyaystvo, no. 12, pp. 373-378.

3. Verhunov V. A. (2006) Narysy istorii ahrarnoi nauky, osvity ta tekhniky [Essays on the history of agricultural science, education and technology]. Kyiv: Ahrarna nauka. (in Ukrainian)

4. Verhunov V. A., Kovalenko S. D. (2001) Profesor Budrin Petro Vasylovych (1857-1939): bibliohrafichnyi pokazhchyk naukovykh prats [Professor Budrin Petr Vasilievich (1857-1939): bibliographic index of scientific papers]. Kyiv: Ahrarna nauka. (in Ukrainian)

5. Veshnyakov V. (1866) Obzor sel'skokhozyaystvennykh uchrezhdeniy v Anglii, Frantsii, Bel'gii, Gollandii, Germanii $i$ Italii [Overview of agricultural institutions in England, France, Belgium, Holland, Germany and Italy]. Sankt-Peterburg. (in Russian)

6. Zaykevich A. E. (1891) Agronomiya kak nauka voobshche $i$ universitetskaya $v$ chastnosti [Agronomy as a science in general and university in particular]. Khar'kov: Tip. V. Biryukova. (in Ukrainian)

7. Zaykevich A. E. (1892) Agronomiya, kak nauka voobshche i universitetskaya $\mathrm{v}$ chastnosti [Agronomy as a science in general and 
university in particular]. Trudy vtorogo Kievskogo oblastnogo s'ezda [Proceedings of the Second Kiev Regional Congress]. Kiev: Tip. P. Barskogo, pp. 34-68.

8. Kostenko O. O. (2004) Universytety XIX st. ta poshyrennia naukovykh ahronomichnykh znan u Yevropi [XIX century universities and the dissemination of agronomic knowledge in Europe]. Proceedings of the Materialy druhoho mizhrehionalnoho naukovo-praktychnoho seminaru molodykh vchenykh, (Luhansk, serpen 27-28, 2004), Luhansk, pp. 32-36.

9. Krtsimovskiy R. (1927) Razvitie osnovnykh printsipov nauki o sel'skom khozyaystve $v$ Zapadnoy Evrope [Development of the basic principles of agricultural science in Western Europe]. Moskva: Novyy agronom. (in Russian)

10. Lebedintsev A. A., Shchusev S. V. (1894) Ustroystvo i deyatel'nost' opytnoy sel'skokhozyaystvennoy stantsii v "Galle" [The design and operation of the experimental agricultural station in Galle]. Vol. 4, pp. 12-28.

11. Melnychuk D. O., Zubets M. V. (2005) Stanovlennia $i$ rozvytok ahrarnoi osvity ta nauky v Ukraini ( $z$ naidavnishykh chasiv do sohodennia) [The formation and development of agricultural education and science in Ukraine (from ancient times to the present)]. Kyiv: NAU. (in Ukrainian)

12. Meshcherskiy I. I. (1893) Vysshee sel'skokhozyaystvennoe obrazovanie $v$ Rossii $i$ za granitsey [Higher agricultural education in Russia and abroad]. Sankt-Peterburg. (in Russian)

13. Morachevskiy V. V. (1914) Rasprostranenie sel'skokhozyaystvennykh znaniy [Agricultural extension]. Agronomicheskaya pomoshch'v Rossii. Petrograd. pp. 259-345.

14. Nikonov A. A. (1995) Nauchnye uchrezhdeniya i uchebnye zavedeniya sel'skokhozyaystvennogo profilya [Scientific and agricultural educational institutions]. Spiral' mnogovekovoy dramy: agrarnaya nauka $i$ politika Rossii (XVIII - XX vv.). Moskva. pp. 112-120.

15. Savel'ev A. Ya., Momot A. I., Khoteenkov V. F. (1995) Vysshee obrazovanie v Rossii: ocherk istorii do 1917 goda [Higher Education in Russia: A History Outline Before 1917]. Moskva: NII VO. (in Russian) 
16. Sazanov V. I. (1962) Sel'skokhozyaystvennoe opytnoe delo v rastenievodstve $i$ ego metodika [Agricultural Experiment in Crop Production and its Methodology]. Moskva: Sel'khozizdat. (in Russian)

17. Smintin V. A. (2000) Istoriya Odes'kogo universitetu (1865-2000) [History of Odessa University (1865-2000)]. Odesa: AstroPrint. (in Ukrainian).

18. Sokolovskyi O. (1895) Z podorozhuvannia do Anhlii: (naukovi zvity) [From a trip to England: (scientific reports)]. B.m., b.r. pp. 109-119.

19. Fausek V. (1897) Nekotorye nauchno-prikladnye uchrezhdeniya Ital'yanskogo ministerstva zemledeliya [Some scientific and applied institutions of the Italian Ministry of Agriculture]. Sankt-Peterburg. (in Russian)

20. Ferlyudin P. (1893) Istoricheskoe obozrenie mer po vysshemu obrazovaniyu $v$ Rossii [Historical Review of Higher Education Measures in Russia]. Saratov: Akademiya nauk i universitety. (in Russian)

\section{Information about the author: Svetlana Hordenko,}

Candidate of Historical Sciences (Ph.D.), Associate Professor Department of Biomedical Discipline of Valeology SHEI "Pereiaslav-Khmelnytskyi Hryhorii Skovoroda State Pedagogical University" Sukhomlynskyi str., 30, Pereiaslav-Khmelnytskyi, 08400 ORCID ID: orcid.org/0000-0003-3581-8630 


\section{ECOLOGIZATION OF AGRICULTURAL PRODUCTION: DEVELOPMENT OF INTRODUCTION OF INNOVATIVE TECHNOLOGIES IN UKRAINE AT THE BEGINNING OF THE $21^{\text {st }}$ CENTURY}

\section{Nataliia Kovalenko}

\section{INTRODUCTION}

At the beginning of the $21^{\text {st }}$ century, Ukraine became one of the most polluted and ecologically troubled countries in the world. The level of environmental load in Ukraine has several times exceeded the similar indicators of other countries ${ }^{1}$. The state of land resources in Ukraine is nearing a critical point: land degradation processes, significant manifestations of wind and water erosion and soil pollution are noted throughout its territory ${ }^{2}$.

Therefore, an important measure was the ecologization of agricultural production, which envisages the practical application of a scientifically sound set of interrelated agrotechnical, reclamation, soil protection and organizational and economic measures ${ }^{3}$. They aimed at efficient use of soil, climatic resources, biological potential of plants in order to obtain stable crops under conditions of increasing soil fertility and maintaining ecological safety of the environment and grown products ${ }^{4}$. To solve this

${ }^{1}$ Orekhivskyi, V. D. (2017) Evoliutsiia naukovykh osnov orhanichnoho zemlerobstva v Ukraini (druha polovyna XIX - pochatok XXI st.): monohrafiia [Evolution of the scientific basis of organic agriculture in Ukraine (the second half of XIX is beginning of XXI of century): monograph]. Vinnytsia: TOV «Nilan-LTD», p. 7. (in Ukrainian).

2 Kovalenko, N.P. (2014) Stanovlennia ta rozvytok naukovo-orhanizatsiinykh osnov zastosuvannia vitchyznianykh sivozmin u systemakh zemlerobstva (druha polovyna XIX-pochatok XXI st.): monohrafiia [Becoming and development of scientifically-organizational bases of application of home crop rotations in the systems of agriculture (the second half of XIX is beginning of XXI of century): monograph]. Kyiv: TOV «Nilan-LTD», p. 342. (in Ukrainian).

${ }^{3}$ Kovalenko, N. P. (2017) Naukovi osnovy stanovlennia ta rozvytku zemlerobstva $v$ Ukraini [Scientific bases of becoming and development of agriculture are in Ukraine]. Visnyk ahrarnoi nauky, no. 5, p. 63. (in Ukrainian).

4 Bahorka, M. O. (2017) Osnovni napriamy ta mekhanizmy ekolohizatsii ahrarnoho vyrobnytstva [Main directions and mechanisms of greening of agricultural production]. Naukovyi visnyk Uzhhorodskoho natsionalnoho universytetu, vol. 16, p. 14. (in Ukrainian). 
problem, great importance was attached to the introduction of ecological innovations with the aim of restoring quality components of the environment due to the process of self-renewal based on the use of the latest ecologically friendly innovative technologies ${ }^{5}$.

In the $2000^{\mathrm{s}}$, ecologization of agriculture was a complex, objectively natural process, driven by changes in the modern paradigm of development of the world economic complex in the direction of ensuring the sustainable functioning of the global economic system, taking into account ecology challenges and threats ${ }^{6}$. The effectiveness of systemic sectoral transformations depended on a set of measures of national, regional and international focus, designed to create an ecology sound basis for the development of each component of the agrarian complex ${ }^{7}$. The ecology orientation of agricultural production in Ukraine involved the search for such methods of organization economic activity that ensured the demand for the products of the industry, while reducing the negative impact on the environment and promoting sustainable rural development ${ }^{8}$.

Solving the problem of ecologization agricultural production with the introduction of innovative technologies has contributed to solving important societal goals. In particular, the formation of a positive image of the state, the promotion of sustainable development of the agricultural sector, the creation of a favorable environment for future generations ${ }^{9}$.

5 Kovalova, O. V. (2008) Prohramno-tsilovyi pidkhid do upravlinnia ekolohospriamovanym silskohospodarskym vyrobnytstvom [A programmatic approach to the management of environmentally-oriented agricultural production]. Ekonomika APK. no. 2. p. 105. (in Ukrainian).

6 Tsybuliak, A. H. (2016) Ekolohizatsiia silskoho hospodarstva $v$ umovakh hlobalizatsii [Ecologization of agriculture in the conditions of globalization]. Ahrosvit, no. 9, p. 37. (in Ukrainian).

${ }^{7}$ Polehenka, M. A. (2017) Osoblyvosti innovatsiinoi diialnosti v ahropromyslovykh pidpryiemstvakh [Features of innovative activity in agro-industrial enterprises]. Ahrosvit, no. 6, p. 49. (in Ukrainian).

${ }^{8}$ Bahorka, M. O. (2017) Osnovni napriamy ta mekhanizmy ekolohizatsii ahrarnoho vyrobnytstva [Main directions and mechanisms of greening of agricultural production]. Naukovyi visnyk Uzhhorodskoho natsionalnoho universytetu, vol. 16, p. 16. (in Ukrainian).

${ }^{9}$ Kovalenko, N. P. (2017) Naukovi osnovy stanovlennia ta rozvytku zemlerobstva $v$ Ukraini [Scientific bases of becoming and development of agriculture are in Ukraine]. Visnyk ahrarnoi nauky, no. 5, p. 66. (in Ukrainian). 


\section{Development of theoretical-methodological foundations of ecological innovations in agricultural production of Ukraine}

At the beginning of the $21^{\text {st }}$ century, ecologization of agricultural production in Ukraine was linked to innovation and was considered an integral part of its development ${ }^{10}$. In an environment of limited and significant depletion of Ukraine's natural resource potential, ecological innovations based on resource-saving and energy-saving technologies, ensuring rational use of the environment with minimizing the negative impact on the environment, and the production of ecologically friendly products, played an important role ${ }^{11}$.

Innovation is understood as a newly created or improved competitive technology, product or service, as well as organizationaltechnical solutions of a production nature, which significantly improved the quality of agricultural production ${ }^{12}$. Innovative technology was technology developed on the basis of the latest scientific knowledge, which by their technological characteristics corresponded to the level of the best world standards in agricultural production and were able to secure leading positions in the world market of knowledge-intensive products $^{13}$.

The essence of innovation in the agricultural sector was to develop and implement in the agrarian production of new progressive management methods. They differed in the variety of regional, sectoral, functional,

10 Tsybuliak, A. H. (2016) Ekolohizatsiia silskoho hospodarstva v umovakh hlobalizatsii [Ecologization of agriculture in the conditions of globalization]. Ahrosvit, no. 9, p. 35. (in Ukrainian).

11 Kovalenko, N. P. (2014) Stanovlennia ta rozvytok naukovo-orhanizatsiinykh osnov zastosuvannia vitchyznianykh sivozmin u systemakh zemlerobstva (druha polovyna XIX - pochatok XXI st.): monohrafiia [Becoming and development of scientifically-organizational bases of application of home crop rotations in the systems of agriculture (the second half of XIX is beginning of XXI of century): monograph]. Kyiv: TOV «Nilan-LTD», p. 357. (in Ukrainian).

12 Sotnyk, I. M. \& Chumakova, M. M. (2013) Rynok ekolohichnykh innovatsii ta problemy yoho rozvytku [The eco-innovation market and its development problems]. Mekhanizm rehuliuvannia ekonomiky, no. 3, p. 45. (in Ukrainian).

13 Bahorka, M. O. (2017) Osnovni napriamy ta mekhanizmy ekolohizatsii ahrarnoho vyrobnytstva [Main directions and mechanisms of greening of agricultural production]. Naukovyi visnyk Uzhhorodskoho natsionalnoho universytetu, vol. 16, p. 16. (in Ukrainian). 
technological and organizational features. In particular, the long duration of the development process and the highly efficient nature of innovation, the key role of research institutions in the process of innovation development, and the consideration of soil and climatic conditions ${ }^{14}$.

Agrarian innovation was an innovation implemented in the agricultural sector to ensure a stable and expanded reproduction of agricultural production. Important was the implementation in the practice of research and development results in the form of new agrarian technologies in agriculture, crop production, soil science, seed production, mechanization and animal husbandry. In particular, disease-resistant, pests and adverse soil and climatic conditions of plant varieties, productive breeds and species of animals and poultry, types of fertilizers and plant and animal protection products, methods of prevention and treatment animals and poultry, biotechnologies that have provided high quality, useful products that had a health and preventive effect ${ }^{15}$. Agrarian innovations included new technical means and technologies of soil cultivation, purification and storage of raw materials; resource-saving and energysaving technologies and ecological innovations, which ensured increasing the productivity of agricultural production, minimizing costs and guaranteeing ecological safety of the environment ${ }^{16}$.

Innovative technologies in agrarian production underwent four stages of development: development of innovations, as a framed result of basic or applied research in the form of development or experimental works, their testing and verification, reproduction, and introduction into production $^{17}$. At the beginning of the $21^{\text {st }}$ century, the main producer of

14 Polehenka, M. A. (2017) Osoblyvosti innovatsiinoi diialnosti $v$ ahropromyslovykh pidpryiemstvakh [Features of innovative activity in agro-industrial enterprises]. Ahrosvit, no. 6, p. 51. (in Ukrainian).

${ }^{15}$ Demydenko, L. M. (2016) Orhanizatsiino-ekonomichni napriamy innovatsiinoho rozvytku silskohospodarskykh pidpryiemstv [Organizational and economic directions of innovative development of agricultural enterprises]. Naukovyi visnyk Khersonskoho derzhavnoho universytetu, vol. 20, p. 73. (in Ukrainian).

16 Polehenka, M. A. (2017) Osoblyvosti innovatsiinoi diialnosti $v$ ahropromyslovykh pidpryiemstvakh [Features of innovative activity in agro-industrial enterprises]. Ahrosvit, no. 6, p. 50. (in Ukrainian).

${ }^{17}$ Demydenko, L. M. (2016) Orhanizatsiino-ekonomichni napriamy innovatsiinoho rozvytku silskohospodarskykh pidpryiemstv [Organizational and economic directions of innovative development of agricultural enterprises]. Naukovyi visnyk Khersonskoho derzhavnoho universytetu, vol. 20, p. 72. (in Ukrainian). 
innovations in the agricultural sector was the network of research institutions of the National Academy of Agricultural Sciences of Ukraine and the Ministry of Agrarian Policy and Food of Ukraine. The most common innovations included: new plant varieties and hybrids and animal breeds; strains of microorganisms; brands and modifications of agricultural machinery; technology; chemical and biological preparations, vaccines; economic developments - documented methodologies, recommendations, etc. ${ }^{18}$ Testing and checking of innovations were carried out by special state scientific institutions. Reproduction of innovations in the agricultural industry was carried out as follows: seed farms grew elite and reproductive seeds of new varieties and hybrids of crops; breeding plants bred pure breeds of animals; machine-building enterprises carried out serial production of new equipment; biological factories produced vaccines and the like. The introduction of development into production, or the transformation of innovation into innovation, was undertaken at the initiative of business entities for the purpose of commercial gain.

Ecological innovations were the final product of ecologyinnovation activity in the creation, use and introduction into production of ecology-oriented innovation, which was realized in the form of ecologically friendly goods, products and services, technologies of their production, management methods at all stages of production and marketing ${ }^{19}$. They ensured the development and improvement of the socio-economic efficiency of the functioning of economic entities, promoted resource and ecological security, and minimized the negative impact on the environment ${ }^{20}$. The main criteria for ecological innovation were scientific and technological progress, practical

${ }^{18}$ Serediuk, Yu. I. \& Shmatkovska, T. O. (2015) Osoblyvosti innovatsii v silskomu hospodarstvi [Features of innovation in agriculture]. Problemy formuvannia ta rozvytku innovatsiinoi infrastruktury: yevropeiskyi vektor - novi vyklyky ta mozhlyvosti: tezy dopovidei III Mizhnarodnoi naukovo-praktychnoi konferentsii (Ukraine, Lviv, May 14-16, 2015). Lviv: Vydavnytstvo Lvivskoi politekhniky, p. 305. (in Ukrainian).

19 Tsybuliak, A. H. (2016) Ekolohizatsiia silskoho hospodarstva $v$ umovakh hlobalizatsii [Ecologization of agriculture in the conditions of globalization]. Ahrosvit, no. 9, p. 37. (in Ukrainian).

20 Kovalenko, N. P. (2012) Ekolohichno zbalansovani sivozminy $v$ systemi alternatyvnoho zemlerobstva: istorychni aspekty [Ecologically balanced crop rotations in the system of alternative agriculture: historical aspects]. Ahroekolohichnyy zhurnal, no. 4, p. 96. (in Ukrainian). 
implementation and the ability to meet the needs through their implementation in the market ${ }^{21}$.

Environmental innovations were divided into: environmental technologies - means of control, elimination and prevention of pollution, compliance with sanitary boundaries. In addition, there were ecological efficient innovations - fundamentally new or modified products, processes and services that generate profit for the manufacturer and the consumer while contributing to the reduction of environmental pollution. There have also systemic innovations - largescale changes in production and consumption systems, as well as waste management systems within a country or region ${ }^{22}$.

At the beginning of the $21^{\text {st }}$ century, the development of state programs aimed at the creation of ecological technologies in developed countries of the world was actively developing. In particular, Japan has created a public-private and private sector research center for innovative technologies for the Earth. Its main focus is on global warming and the development of alternative energy sources. In Germany, the Ministry of Research and Technology's Environmental Technology Program operated. A technology and technology transfer organization has been set up in the Netherlands, with ecological technology accounting for about $10 \%$ of its activities. A Technology Innovation Fund was set up in Italy, where $5 \%$ of the money was used for ecological technologies. The Environmental Technology Solutions Program was operating in Canada. In many countries, the task of developing ecological technologies has been part of existing scientific and technical programs in research institutions ${ }^{23}$.

Great importance for the development of ecologization of domestic agricultural production is attached to the draft Law of Ukraine

${ }^{21}$ Khodakivska, O. V. (2015) Ekolohizatsiia ahrarnoho vyrobnytstva: monohrafiia [Ecologization of agricultural production: monograph]. Kyiv: NNTs IAE, p. 259. (in Ukrainian).

${ }^{22}$ Sotnyk, I. M. \& Chumakova, M. M. (2013) Rynok ekolohichnykh innovatsii ta problemy yoho rozvytku [The eco-innovation market and its development problems]. Mekhanizm rehuliuvannia ekonomiky, no. 3, pp. 39-40. (in Ukrainian).

23 Bahorka, M. O. (2017) Osnovni napriamy ta mekhanizmy ekolohizatsii ahrarnoho vyrobnytstva [Main directions and mechanisms of greening of agricultural production]. Naukovyi visnyk Uzhhorodskoho natsionalnoho universytetu, vol. 16, p. 15. (in Ukrainian). 
"On Agriculture". It states that ecologization of agriculture was a system of national, sectoral and regional measures. They were aimed at introducing into the practice of agricultural production qualitatively new, ecologically safe types of machinery, technologies and organization of material production, methods and methods of functioning of agrarian and agro-industrial complexes. For the rational use of natural resources, their conservation, reproduction and maintenance of dynamic ecological balance in the environment ${ }^{24}$.

Innovation processes were regulated by the Law of Ukraine "On Innovative Activity", which defined the legal, economic and organizational principles of state regulation of innovation activity in the country $^{25}$. Its main purpose was to create socio-economic, organizational and legal conditions for the effective reproduction, development and use of scientific and technical potential of the country, ensuring the introduction of modern ecologically friendly, safe, energysaving and resource-saving technologies, production and sale of new types of competitive products.

Important was the Law of Ukraine "On the Fundamental Principles (Strategy) of the State Environmental Policy of Ukraine for the Period until 2030", which established the factors of ecological problems and main directions of development of the country's ecological policy ${ }^{26}$. Factors of ecological problems were: the subordination of ecological priorities to economic feasibility and the neglect of environmental consequences in the legislative and regulatory decisions of executive authorities. Ecological problems were exacerbated by the predominance of resource-intensive and energy-intensive industries with a negative impact on the environment, which was exacerbated by the lack of regulation in the transition to market conditions; unsatisfactory state of

${ }^{24}$ Sotnyk, I. M. \& Chumakova, M. M. (2013) Rynok ekolohichnykh innovatsii ta problemy yoho rozvytku [The eco-innovation market and its development problems]. Mekhanizm rehuliuvannia ekonomiky, no. 3, p. 42. (in Ukrainian).

${ }^{25}$ Zakon Ukrainy № 40-IV «Pro innovatsiinu diialnist» vid 5 hrudnia 2012 r. [Law of Ukraine no. 40-IV «On Innovative Activity» of December 5, 2012]. Retrieved from: https://zakon.rada.gov.ua/laws/show/40-15 (accessed 30 September 2019). (in Ukrainian).

26 Zakon Ukrainy № 2697-VIII ««Pro Osnovni zasady (stratehiiu) derzhavnoi ekolohichnoi polityky Ukrainy na period do 2030 roku» vid 28 liutogo 2019 r. [«On the Fundamental Principles (Strategy) of the State Environmental Policy of Ukraine for the Period up to 2030» of February 28, 2019]. Retrieved from: https://zakon.rada.gov.ua/ laws/show/2697-19 (accessed 30 September 2019). (in Ukrainian). 
the system of state monitoring of the environment. The development of ecological problems has led to: a low level of understanding in society of the priorities of environmental protection and the benefits of balanced (sustainable) development, the imperfection of the system of ecological education. Unsatisfactory level of compliance with environmental legislation and ecological rights and obligations of citizens; insufficient funding from state and local budgets for environmental measures. At the same time, the main directions of development of Ukraine's ecological policy were: stabilization and improvement of the environment, guaranteeing an ecological safe environment for the life and health of the population, as well as introduction of an ecologically balanced system of nature use and conservation of the country's natural ecosystems.

At the beginning of the $21^{\text {st }}$ century, there were a number of unresolved problems at the domestic enterprises regarding the effective implementation of ecological innovations. These negative tendencies were accompanied by the loss of competitiveness of agricultural enterprises not only internationally but also locally. In recent years, innovation activity in agriculture has slowed down substantially, reducing both the number and quality of scientific developments performed and the number of scientists, which has resulted in a decrease in the state funding of their scientific activity ${ }^{27}$. The economic relations between science and production were not well established, and scientific developments were slowly being introduced into production. The renewal of agricultural production with new varieties, machinery and technologies was hampered by the lack of financial support for agricultural producers and their lack of awareness of the latest achievements of domestic agrarian science.

Agrarian enterprises of Ukraine needed an ecologically friendly restructuring of production activities, which included: rational use of land, which was accompanied by conservation and increase of soil fertility. In addition, there were ensuring the optimal level of plowed land, which prevented the development of water and wind erosion of the soil; compliance with the requirements to prevent exceeding the

27 Polehenka, M. A. (2017) Osoblyvosti innovatsiinoi diialnosti v ahropromyslovykh pidpryiemstvakh [Features of innovative activity in agro-industrial enterprises]. Ahrosvit, no. 6, p. 51. (in Ukrainian). 
maximum permissible standards of contamination of agricultural production, ensuring its ecologically friendliness ${ }^{28}$. It was important to follow the established rules for the transportation, storage and application of mineral fertilizers, plant and animal protection; prevention of pollution by chemical means of environment and food; compliance with ecological requirements during the design, construction, reconstruction and commissioning of new buildings and structures, reclamation systems, etc. ${ }^{29}$

In order to stimulate the innovation activity of enterprises, an important trend was the creation of innovative programs, which included the coordination of organizational objectives for the development and implementation of innovative products. An innovative strategy for long-term growth based on sustainable development has become widespread, which has become a common concept on the need to strike a balance between meeting contemporary needs and protecting the interest of future generations, including their need for an ecologically friendly environment ${ }^{30}$. This concept led to the expansion of the introduction of ecological innovations, which included the production of ecologically friendly products, the use of ecologically friendly resource-saving and energy-saving technologies of production, which provided a sustainable improvement of the ecological situation and increased efficiency of agricultural production, saving jobs and improving living standards.

28 Kovalenko, N. P. (2014) Stanovlennia ta rozvytok naukovo-orhanizatsiinykh osnov zastosuvannia vitchyznianykh sivozmin u systemakh zemlerobstva (druha polovyna XIX-pochatok XXI st.): monohrafiia [Becoming and development of scientifically-organizational bases of application of home crop rotations in the systems of agriculture (the second half of XIX is beginning of XXI of century): monograph]. Kyiv: TOV «Nilan-LTD», p. 348. (in Ukrainian).

29 Orekhivskyi, V. D. (2017) Evoliutsiia naukovykh osnov orhanichnoho zemlerobstva $v$ Ukraini (druha polovyna XIX - pochatok XXI st.): monohrafiia [Evolution of the scientific basis of organic agriculture in Ukraine (the second half of XIX is beginning of XXI of century): monograph]. Vinnytsia: TOV «Nilan-LTD», p. 186. (in Ukrainian).

30 Polehenka, M. A. (2017) Osoblyvosti innovatsiinoi diialnosti v ahropromyslovykh pidpryiemstvakh [Features of innovative activity in agro-industrial enterprises]. Ahrosvit, no. 6, p. 53. (in Ukrainian). 


\section{Improvement of practical implementation of ecological innovations in organic agriculture of Ukraine}

At the beginning of the $21^{\text {st }}$ century, innovations in organic agriculture became a component of ecologization of agricultural production in Ukraine $^{31}$. Examples of such ecological innovations include the production of organic agricultural products using organic seeds and scientifically based alternation of crops, organic fertilizers, soil protection, biological plant protection products and more. The introduction of ecological innovations in agricultural enterprises was carried out simultaneously with traditional production, as it was aimed at improving or creating new products and significantly updating production technologies. At the same time, the transition to renewed production required additional costs of finance, time, energy, etc., which could only be ensured by the effective management of agricultural production ${ }^{32}$.

During the $2000^{\mathrm{s}}$, Ukraine, with significant potential for its own production of organic agricultural products, its export and consumption in the domestic market, achieved certain results in its development. This was facilitated by the adopted Law of Ukraine "On Basic Principles and Requirements for Organic Production, Circulation and Labeling of Organic Products", which was implemented on August 2, 2019 ${ }^{33}$. This Law of Ukraine defines the basic principles and requirements for organic production, circulation and labeling of organic products. The principles of legal regulation of the production and functioning of the organic produce market, legal bases of activity of the central executive bodies and directions of state policy in the specified sphere are established.

${ }^{31}$ Khodakivska, O. V. (2015) Ekolohizatsiia ahrarnoho vyrobnytstva: monohrafiia [Ecologization of agricultural production: monograph]. Kyiv: NNTs IAE, p. 5. (in Ukrainian).

${ }^{32}$ Orekhivskyi, V. D. (2017) Evoliutsiia naukovykh osnov orhanichnoho zemlerobstva v Ukraini (druha polovyna XIX - pochatok XXI st.): monohrafiia [Evolution of the scientific basis of organic agriculture in Ukraine (the second half of XIX is beginning of XXI of century): monograph]. Vinnytsia: TOV «Nilan-LTD», p. 229. (in Ukrainian).

${ }^{33}$ Zakon Ukrainy № 2496-VIII «Pro osnovni pryntsypy ta vymohy do orhanichnoho vyrobnytstva, obihu ta markuvannia orhanichnoi produktsii» vid 10 lypnia $2018 \mathrm{r}$. [Law of Ukraine no. 2496-VIII «On the basic principles and requirements for organic production, circulation and labeling of organic products» of July 10, 2018]. Retrieved from: https://zakon.rada.gov.ua/laws/show/2496-19 (accessed 30 September 2019). (in Ukrainian). 
According to the Federation of Organic Movement of Ukraine, the domestic consumer market for organic products in the country began to develop from the early $2000^{\mathrm{s}}$. Most of the agricultural enterprises producing organic products were located in Western Ukraine, Vinnytsia, Dnipropetrovsk, Zhytomyr, Kyiv, Odesa, Poltava, Kherson, Chernihiv regions ${ }^{34}$. They specialized mainly in the cultivation of cereals, legumes and oilseeds, some combining the use of organic technologies in plant and animal husbandry ${ }^{35}$.

The development and implementation of innovative technologies for the ecologization of agricultural production in different soil and climatic conditions of Ukraine was carried out by scientists of the National Scientific Center "Institute of Agriculture of NAAS". They have developed the optimal structure of sown areas and scientifically substantiated crop rotations on the basis of a point evaluation of precursors and periods of return to the previous place of cultivation ${ }^{36}$. In the early $2000^{\mathrm{s}}$, these technologies were introduced in the farms of Rivne $^{37,38}$ and Poltava region ${ }^{39,40}$. The farms used a system of

34 Orekhivskyi, V. D. (2018) Osoblyvosti rozvytku ahrarnykh pidpryiemstv $z$ vyrobnytstva orhanichnoi produktsii v Ukraini (1990-ti - 2000-ni roky) [Features of development of agricultural enterprises for organic production in Ukraine $\left(1990^{\mathrm{s}}-\right.$ $\left.2000^{\mathrm{s}}\right)$ ]. Hileia, vol. 133, p. 67. (in Ukrainian).

35 Orekhivskyi, V. D. (2017) Evoliutsiia naukovykh osnov orhanichnoho zemlerobstva $v$ Ukraini (druha polovyna XIX - pochatok XXI st.): monohrafiia [Evolution of the scientific basis of organic agriculture in Ukraine (the second half of XIX is beginning of XXI of century): monograph]. Vinnytsia: TOV «Nilan-LTD», p. 303. (in Ukrainian).

36 Kovalenko, N. P. (2014) Stanovlennia ta rozvytok naukovo-orhanizatsiinykh osnov zastosuvannia vitchyznianykh sivozmin u systemakh zemlerobstva (druha polovyna XIX - pochatok XXI st.): monohrafiia [Becoming and development of scientifically-organizational bases of application of home crop rotations in the systems of agriculture (the second half of XIX is beginning of XXI of century): monograph]. Kyiv: TOV «Nilan-LTD», p. 226. (in Ukrainian).

${ }^{37}$ Boiko, P., Kovalenko, N., Poliovyi, V. \& Panasiuk, M. (2002) Dosvid i praktyka «Zorianskoii akademiii» [Experience and practice of «Zorianska of academy»]. Propozycija, no. 11, pp. 26-28. (in Ukrainian).

38 Boiko, P., Kovalenko, N., Poliovyi, V. \& Panasiuk, M. (2002) Dosvid i praktyka «Zorianskoii akademiii» [Experience and practice of «Zorianska of academy»]. Propozyciia, no. 12, pp. 36-38. (in Ukrainian).

39 Boiko, P. I. \& Kovalenko, N. P. (2005) Naukovo obgruntovani sivozminy $i$ systema rilnyctva u velykotovarnomu ghospodarstvi [Scientifically reasonable crop rotations and system of field-crop cultivation in large commodity economy]. Propozyciia, no. 6, pp. 38-42. (in Ukrainian). 
specialized rotary crop rotations for growing cattle, pigs and poultry using post-harvest and sidereal crops ${ }^{41}$, by-products, tillage, local organic fertilizers - manure, slurry, compost, peat; agrotechnical, biological and organizational measures of plant protection ${ }^{42}$; soil erosion changes were introduced on hazardous erosion crop rotations ${ }^{43}$.

Scientists of the Odessa State Agricultural Experimental Station of NAAS for the arid conditions of the Southern Steppe of Ukraine scientifically substantiated and practically tested innovative technology of preparation of a sidereal steam, which was effectively used in the farms of the Odessa region ${ }^{44}$. With this technology, the aboveground biomass was not plowed up, but crushed with disk implements and partially mixed with the surface layer of soil, which reliably protected it from wind and water erosion and partly from physical evaporation of moisture.

Scientists of the National University of Life and Environmental Sciences of Ukraine have developed a method of preparation and application of EM-technologies in organic agriculture with the use of effective microorganisms. Such technologies have included the use of EM-preparations: liquids that have a high concentration of effective microorganisms, fermented grains and cereals, as well as fermented

${ }^{40}$ Boiko, P. I. \& Kovalenko, N. P. (2008) Vysokotovarnye khoziaistva kak model racyonalnogho zemleyspolzovanyia [Highly commodity economies as model of the rational use of earth]. Aghrovisnyk Ukraiina, no. 1(24), pp. 24-27. (in Russian).

${ }^{41}$ Boiko, P. I. \& Kovalenko, N. P. (2003) Problemy ekologichno vrivnovazhenyh sivozmin [Problems of the ecologically balanced crop rotations]. Visnyk ahrarnoi nauky, no. 8, p. 10. (in Ukrainian).

42 Boiko, P. I., Borodan, V. O. \& Kovalenko, N. P. (2005) Ekolohichno zbalansovani sivozminy - osnova biolohichnoho zemlerobstva [The Ecologically balanced crop rotations are basis of biological agriculture]. Visnyk ahrarnoi nauky, no. 2, p. 11. (in Ukrainian).

43 Kovalenko, N. P. (2014) Stanovlennia ta rozvytok naukovo-orhanizatsiinykh osnov zastosuvannia vitchyznianykh sivozmin u systemakh zemlerobstva (druha polovyna XIX-pochatok XXI st.): monohrafiia [Becoming and development of scientifically-organizational bases of application of home crop rotations in the systems of agriculture (the second half of XIX is beginning of XXI of century): monograph]. Kyiv: TOV «Nilan-LTD», p. 230. (in Ukrainian).

44 Orekhivskyi, V. D. (2017) Evoliutsiia naukovykh osnov orhanichnoho zemlerobstva $v$ Ukraini (druha polovyna XIX - pochatok XXI st.): monohrafiia [Evolution of the scientific basis of organic agriculture in Ukraine (the second half of XIX is beginning of XXI of century): monograph]. Vinnytsia: TOV «Nilan-LTD», pp. 231-232. (in Ukrainian). 
organic residues $^{45}$. In particular, EM-preparations used to protect plants from harmful organisms in farms of different soil and climatic conditions of Ukraine.

In 2010, scientists of the National Scientific Center "Institute of Agriculture of the NAAS" started the implementation of the scientifictechnical program "Scientific bases for the development of organic production of agricultural products and mechanisms of its functioning in Ukraine”. In particular, the zones of organic production of agricultural products were formed, taking into account the soil and climatic conditions, the optimal area of farms for organic farming was established, organic fertilizers from by-products of crop production and animal husbandry were obtained $^{46}$. The enhancement of the functionality of such organic fertilizers was due to the addition of enzyme and microbiological agents at various stages of composting with the active surface ${ }^{47}$.

Scientists of the Institute of Engineering and Technology "Biotechnics" of the National Academy of Sciences of Ukraine started the implementation of the program "Scientific and engineeringtechnological principles of creation of ecologically safe industrial biotechnologies and equipment for the production and use in agrobiocenoses of biological plant protection products". In particular, they formed an innovative technology for the application of biological plant protection products and determined the main characteristics of vermicultures, adapted to different soil and climatic conditions of Ukraine $^{48}$. These technologies are widely used in farms of different soil and climatic conditions of Ukraine.

45 Stetsyshyn, P. O., Pyndus, V. V. \& Rekunenko, V. V. (2011) Osnovy orhanichnoho vyrobnytstva [Fundamentals of organic production]. Vinnytsia: Nova knyha, p. 43. (in Ukrainian).

46 Orekhivskyi, V. D. (2017) Evoliutsiia naukovykh osnov orhanichnoho zemlerobstva $v$ Ukraini (druha polovyna XIX - pochatok XXI st.): monohrafiia [Evolution of the scientific basis of organic agriculture in Ukraine (the second half of XIX is beginning of XXI of century): monograph]. Vinnytsia: TOV «Nilan-LTD», pp. 289-290. (in Ukrainian).

47 Demydenko, O. V., Boiko, P. I., Blashchuk, M. I., Shapoval, I. S. \& Kovalenko N.P. (2019) Sivozminy ta rodiuchist chornozemu Livoberezhnoho Lisostepu: monohrafiia [Crop rotations and fertility of black earth of Left-bank Foreststeppe: monograph]. Smila: Chornobaivske KPP, p. 374. (in Ukrainian).

${ }_{48}$ Shuvar, I. A., Sendetskyi, V. M. \& Bunchak, O. M. (2015) Vyrobnytstvo ta vykorystannia orhanichnykh dobryv: monohrafiia [Production and use of organic fertilizers: monograph]. Ivano-Frankivsk: Symfoniia forte, p. 4. (in Ukrainian). 
The Association "Bioconversion" has developed new types of ecologically friendly organic fertilizers, which were used in the production of agricultural enterprises of Vinnitsa, Volyn, IvanoFrankivsk, Kyiv, Lviv, Khmelnitsky regions of Ukraine ${ }^{49}$. In particular, the production and use of biohumus by the method of vermiculture; microorganisms obtained from organic wastes of poultry farms, livestock complexes, leather production by aerobic biological fermentation, microbial associations by composting, liquid fertilizer biostimulators - by cavitation, destruction of straw and other plant residues together with sowing.

The Association "Bioconversion", based on the improvement of biohumus production technologies for organic waste by vermiculture method, developed and implemented in the farms of the above regions of Ukraine complex humic preparations from vermicompost: aqueous suspensions and vermicompost teas ${ }^{50}$. The technologies of industrial vermiculture of various kinds of organic waste and production of biohumus were of great importance. In particular, technology of production of organic-mineral fertilizers based on biohumus, technology of vermifiltration - utilization of organic waste with the help of heterotrophic organisms, processing of organic waste with higher edible mushrooms, microbiological transformation of organic waste into biogas. The ways of improvement of initial uterine populations of worms and their adaptation to various organic substrates, of obtaining biologically active preparations from the tissues of the organism of vermiculture were determined ${ }^{51}$.

49 Orekhivskyi, V. D. (2017) Evoliutsiia naukovykh osnov orhanichnoho zemlerobstva $v$ Ukraini (druha polovyna XIX - pochatok XXI st.): monohrafiia [Evolution of the scientific basis of organic agriculture in Ukraine (the second half of XIX is beginning of XXI of century): monograph]. Vinnytsia: TOV «Nilan-LTD», p. 292. (in Ukrainian).

50 Shuvar, I. A., Sendetskyi, V. M. \& Bunchak, O. M. (2015) Vyrobnytstvo ta vykorystannia orhanichnykh dobryv: monohrafiia [Production and use of organic fertilizers: monograph]. Ivano-Frankivsk: Symfoniia forte, p. 103. (in Ukrainian).

${ }^{51}$ Orekhivskyi, V. D. (2017) Evoliutsiia naukovykh osnov orhanichnoho zemlerobstva $v$ Ukraini (druha polovyna XIX - pochatok XXI st.): monohrafiia [Evolution of the scientific basis of organic agriculture in Ukraine (the second half of XIX is beginning of XXI of century): monograph]. Vinnytsia: TOV «Nilan-LTD», p. 228. (in Ukrainian). 
An example of the introduction of innovative technologies for the ecologization of agricultural production was the long-standing practice of the Private enterprise "Agroecology" in Poltava region under the guidance of NAAS academician S. S. Antonets. In particular, the complex of innovative ecological technologies developed and implemented in the economy included: system of dynamic crop rotations with perennial or annual legumes, post-harvest, after-season and sidereal crops with application of local organic fertilizers and byproducts of agricultural crops ${ }^{52}$. This complex provided a permanent vegetation of the soil, which helped to increase the amount of organic matter, ensuring the balance of humus and preventing erosion processes. Dynamic crop rotations provided, if necessary, the replacement of one crop with another, close in biological features, without violating the recommended alternation of crops and the timing of their return to their previous place of cultivation ${ }^{53}$.

The complex of innovative ecological technologies developed and implemented in the economy included the use of soil-protective shallow tillage of soil with mulching, which provided cutting of the root system of plants to a depth of $4-5 \mathrm{~cm}$ without its removal from the soil ${ }^{54}$. For this purpose, special cultivators with rigid attachment of stable paws were used to provide adequate depth of cultivation and sufficient pruning of plants ${ }^{55}$. They were equipped with sickle-shaped rods with

52 Khodakivska, O. V. (2015) Ekolohizatsiia ahrarnoho vyrobnytstva: monohrafiia [Ecologization of agricultural production: monograph]. Kyiv: NNTs IAE, p. 221. (in Ukrainian).

53 Kovalenko, N. P. (2014) Stanovlennia ta rozvytok naukovo-orhanizatsiinykh osnov zastosuvannia vitchyznianykh sivozmin u systemakh zemlerobstva (druha polovyna XIX - pochatok XXI st.): monohrafiia [Becoming and development of scientifically-organizational bases of application of home crop rotations in the systems of agriculture (the second half of XIX is beginning of XXI of century): monograph]. Kyiv: TOV «Nilan-LTD», p. 343. (in Ukrainian).

54 Pysarenko, V. M., Antonets, A. S. \& Pysarenko, P. V. (2017) Systema orhanichnoho zemlerobstva ahroekoloha Semena Antontsia [Organic farming system of agroecologist Semen Antonets]. Poltava: FOP Myron, I. A., p. 20. (in Ukrainian).

55 Orekhivskyi, V. D. (2017) Evoliutsiia naukovykh osnov orhanichnoho zemlerobstva $v$ Ukraini (druha polovyna XIX - pochatok XXI st.): monohrafiia [Evolution of the scientific basis of organic agriculture in Ukraine (the second half of XIX is beginning of XXI of century): monograph]. Vinnytsia: TOV «Nilan-LTD», p. 337. (in Ukrainian). 
rigid mounts for better flooding of plant residues into the fields, as well as paws with a self-sharpening effect in the soil ${ }^{56}$. In 2013, these cultivators were patented and introduced into mass production ${ }^{57}$.

The characteristic feature was the introduction of innovative technology for the introduction of organic fertilizers. In particular, together with siderates and plant residues, organic fertilizers of plant and animal origin were used, which underwent certain transformations under the action of organisms ${ }^{58}$. These included: manure, humus, slurry, bird droppings, sawdust, peat, sapropel and composts and more. In order to obtain manure daily on the litter, the animals were daily strawed for better absorption of the liquid fractions. This helped to increase the amount of nitrogen, slower leaching of nutrients, as well as faster development of bacteria needed for its processing. According to the innovative technology, the manure was not plowed and deep wrapped, only mixed with the surface layer of soil. Thanks to the above technology, they reached the most complete nutrient conservation: the humus remained on the surface for a few hours, so it did not dry out, the nitrogen from it did not evaporate and was not washed out ${ }^{59}$.

The farm has developed innovative technology for storing manure in field cages, which provided mineralization of organic matter by soil microorganisms and earthworms. The technology was to form cords with parallel strips of solid straw manure, where a more liquid fraction

${ }^{56}$ Kovalenko, N. P. (2016) Evoliutsiia vykorystannia znariad obrobitku gruntu $u$ vitchyznianomu zemlerobstvi [Evolution of the use of soil tillage tools in domestic agriculture]. History of science and technique, vol. 8, p. 136. (in Ukrainian).

57 Orekhivskyi, V. D. (2018) Evoliutsiia vprovadzhennia systemy orhanichnoho zemlerobstva v Pryvatnomu Pidpryiemstvi «Ahroekolohiia»u druhii polovyni XX - na pochatku XXI stolit [Evolution of the organic farming system implementation in PE «Agroecology» in the second half of XX - at the beginning XXI of centuries]. Hileia, vol. 130, p. 116. (in Ukrainian).

58 Stetsyshyn, P. O., Pyndus, V. V. \& Rekunenko, V. V. (2011) Osnovy orhanichnoho vyrobnytstva [Fundamentals of organic production]. Vinnytsia: Nova knyha, p. 206. (in Ukrainian).

59 Orekhivskyi, V. D. (2017) Evoliutsiia naukovykh osnov orhanichnoho zemlerobstva $v$ Ukraini (druha polovyna XIX - pochatok XXI st.): monohrafiia [Evolution of the scientific basis of organic agriculture in Ukraine (the second half of XIX is beginning of XXI of century): monograph]. Vinnytsia: TOV «Nilan-LTD», p. 340. (in Ukrainian). 
was placed between them ${ }^{60}$. A few months later, a strip of straw and liquid manure was rolled up, and a few months later, the bulldozers rolled up the next two cahates to free space. Due to this overturning, the mass was mixed, enriched with oxygen, which stimulated the powerful development of bacteria. The finished baguettes were covered with straw, which protected the manure from drying out and absorbed the vapors of valuable nitrogen. In the midst of the cagata, the activity of microorganisms that mineralized fresh manure organic matter into a plant-accessible form did not cease ${ }^{61}$. Such a substrate became a good environment for the development of earthworms that multiplied and humus were introduced into the fields.

A unique innovative technology was the double fertilization of the soil due to the application of manure after the siderates, the advantage of which was its balance. Manure enriched the soil with macroelements, and mushrooms and microorganisms began to decompose the green mass of the siderates, which acted as a catalyst, and then proceeded to decompose manure ${ }^{62}$. The technology of wrapping the siderates was to simultaneously grind the siderates and loosen the soil ${ }^{63}$. Due to the use of innovative dual fertilizer technology, soil fertility has been significantly improved and product quality has been improved.

An innovative technology of soil protection against erosion was developed in the farm, which consisted of the presence of dense stubble

60 Antonets, S. S., Antonets, A. S. \& Pysarenko, V. M. (2010) Orhanichne zemlerobstvo: z dosvidu PP «Ahroekolohiia» Shyshatskoho raionu Poltavskoi oblasti [Organic farming: from the experience of the PE «Agroecology» of Shishatsky district of Poltava region]. Poltava: RVV PDAA, p. 303. (in Ukrainian).

61 Orekhivskyi, V. D. (2017) Evoliutsiia naukovykh osnov orhanichnoho zemlerobstva $v$ Ukraini (druha polovyna XIX - pochatok XXI st.): monohrafiia [Evolution of the scientific basis of organic agriculture in Ukraine (the second half of XIX is beginning of XXI of century): monograph]. Vinnytsia: TOV «Nilan-LTD», p. 341. (in Ukrainian).

62 Pysarenko, V. M., Antonets, A. S. \& Pysarenko, P. V. (2017) Systema orhanichnoho zemlerobstva ahroekoloha Semena Antontsia [Organic farming system of agroecologist Semen Antonets]. Poltava: FOP Myron, I. A., p. 19. (in Ukrainian).

63 Orekhivskyi, V. D. (2017) Evoliutsiia naukovykh osnov orhanichnoho zemlerobstva $v$ Ukraini (druha polovyna XIX - pochatok XXI st.): monohrafiia [Evolution of the scientific basis of organic agriculture in Ukraine (the second half of XIX is beginning of XXI of century): monograph]. Vinnytsia: TOV «Nilan-LTD», p. 335. (in Ukrainian). 
and leaving across the slope of straw rolls, which prevented the washing away of the soil and retained moisture on steep slopes ${ }^{64}$. In winter, stubble delayed the snow, and the snow covered the rolls and strengthened the erosion strips, making the field more secure. To optimize the phytosanitary condition, a set of agro-technical and organizational-economic measures, microbiological preparations were used, economic thresholds of weed, disease and pest control were monitored $^{65}$.

At the beginning of the $21^{\text {st }}$ century, these innovative ecological technologies were tested in many years of scientific research by scientists of the agronomic faculty of the Poltava State Agrarian Academy. During the years of their application in Private enterprise "Agroecology", according to the Poltava Branch of the State Institution "Soil Conservation institut of Ukraine", humus content - the main indicator of soil fertility and efficiency of innovative ecological technologies - increased by $0.53-1.57 \%{ }^{66}$. The soils of the farm were characterized by a sufficient content of the basic trace elements: nitrogen, phosphorus, and potassium. None of the fields in the farm was found to have an excess of heavy metals ${ }^{67}$. Thus, the systematic application of these innovative ecological technologies in the agricultural holdings of Ukraine practically provided the recommended regime of mineral nutrition of the main crops without the introduction of chemicals, contributed to the improvement of the natural environment, increase of soil fertility and growth of production of highquality ecologically friendly products.

${ }^{64}$ Khodakivska, O. V. (2015) Ekolohizatsiia ahrarnoho vyrobnytstva: monohrafiia [Ecologization of agricultural production: monograph]. Kyiv: NNTs IAE, pp. 251-252. (in Ukrainian).

65 Pysarenko, V. M., Antonets, A. S. \& Pysarenko, P. V. (2017) Systema orhanichnoho zemlerobstva ahroekoloha Semena Antontsia [Organic farming system of agroecologist Semen Antonets]. Poltava: FOP Myron, I. A., p. 73. (in Ukrainian).

66 Orekhivskyi, V. D. (2017) Evoliutsiia naukovykh osnov orhanichnoho zemlerobstva $v$ Ukraini (druha polovyna XIX - pochatok XXI st.): monohrafiia [Evolution of the scientific basis of organic agriculture in Ukraine (the second half of XIX is beginning of XXI of century): monograph]. Vinnytsia: TOV «Nilan-LTD», p. 346. (in Ukrainian).

${ }^{67}$ Pysarenko, V. M., Pysarenko, P. V. \& Ponomarenko, S. V. (2017) Orhanichne zemlerobstvo dlya pryvatnoho sektora [Organic agriculture is for a private sector]. Poltava: FOP Myron, I. A., p. 12. (in Ukrainian). 


\section{CONCLUSION}

It can be concluded that in the beginning of $21^{\text {st }}$ century, in Ukraine the solution of the problem of development of innovative activity of agricultural enterprises on the basis of using the achievements of scientific and technological progress in ecologically safe production was complex and multifaceted. The introduction of innovative technologies has become an important task for agricultural enterprises and was defined as a promising direction of development, which created a favorable environment for efficient use of resource potential and formation of their competitiveness. In general, the ecological orientation of agricultural production in Ukraine involved the search for such methods of organization of economic activity that provided satisfaction of demand for products of the industry, while simultaneously reducing the negative impact on the environment and promoting sustainable development of rural territories of the country.

Innovative technologies in agrarian production went through four stages: development of innovations, as a framed result of basic or applied research in the form of development or experimental works, their testing and verification, reproduction, and introduction into production. Ecological innovation was the final product of ecologically-innovation activity in the creation, use and implementation of ecologically friendly innovation, which was implemented in the form of ecologically friendly goods, products and services, production technologies, management methods at all stages of production and marketing.

At the beginning of the $21^{\text {st }}$ century, innovations in organic agriculture became a component of greening agricultural production. In particular, the production of organic agricultural products using organic seeds and scientifically sound alternation of crops, organic fertilizers, soil protection, biological plant protection products and more. Their systematic application in the agricultural farms of Ukraine practically provided the recommended regime of mineral nutrition of the basic crops without introducing chemicals, helped to improve the environment and to increase the production of high-quality ecologically friendly products.

\section{SUMMARY}

The article describes the process of development of theoretical and methodological foundations of ecological innovations in agricultural 
production of Ukraine at the beginning of the $21^{\text {st }}$ century. It was found that ecological innovations based on resource-saving and energy-saving technologies ensured rational use of the environment while minimizing the negative impact on the environment, as well as the production of ecologically friendly products. The effectiveness of new ecological technologies in agriculture, crop production, soil science, seed production, mechanization and animal husbandry has been determined. Their use has ensured the increase of agricultural production productivity, cost minimization and guaranteed ecology safety of the country's environment.

The effectiveness of practical implementation of ecological innovations in organic agriculture of Ukraine at the beginning of the $21^{\text {st }}$ century has been established. Examples of the development of innovative ecological technologies by scientists of research institutions and their effective implementation in certified organic farms of Ukraine are given. In particular, the optimal structure of the acreage and scientifically sound crop rotations based on the point evaluation of the precursors and the periods of return to the previous place of cultivation. The technologies of biohumus production by vermiculture, preparations based on effective microorganisms, and biological plant protection products were important. The efficiency of soil-free shallow tillage of soil with mulching, preparation of sidereal steam, double fertilization due to manure and sideration, protection of soil from erosion has been established. It was found out that their systematic practical application in the agrarian farms of Ukraine provided the recommended regime of mineral nutrition of the basic crops without introduction of chemicals, contributed to increase of soil fertility, improvement of the environment and increase of production of high-quality ecologically friendly products.

\section{REFERENCES}

1. Antonets, S. S., Antonets, A. S. \& Pysarenko, V. M. (2010) Orhanichne zemlerobstvo: $z$ dosvidu PP "Ahroekolohiia” Shyshatskoho raionu Poltavskoi oblasti [Organic farming: from the experience of the PE"Agroecology" of Shishatsky district of Poltava region]. Poltava: RVV PDAA, 200 s. (in Ukrainian).

2. Bahorka, M. O. (2017) Osnovni napriamy ta mekhanizmy ekolohizatsii ahrarnoho vyrobnytstva [Main directions and mechanisms of greening of agricultural production]. Naukovyi visnyk 
Uzhhorodskoho natsionalnoho universytetu, vol.16, pp. 13-16. (in Ukrainian).

3. Boiko, P., Kovalenko, N., Poliovyi, V. \& Panasiuk, M. (2002) Dosvid i praktyka "Zorianskoii akademiii" [Experience and practice of "Zorianska of academy"]. Propozycija, no.11, pp.26-28. (in Ukrainian).

4. Boiko, P., Kovalenko, N., Poliovyi, V. \& Panasiuk, M. (2002) Dosvid i praktyka "Zorianskoii akademiii" [Experience and practice of "Zorianska of academy"]. Propozyciia, no.12, pp.36-38. (in Ukrainian).

5. Boiko, P. I. \& Kovalenko, N. P. (2003) Problemy ekologichno vrivnovazhenyh sivozmin [Problems of the ecologically balanced crop rotations]. Visnyk ahrarnoi nauky, no. 8, pp. 9-13. (in Ukrainian).

6. Boiko, P. I., Borodan, V. O. \& Kovalenko, N. P. (2005) Ekolohichno zbalansovani sivozminy - osnova biolohichnoho zemlerobstva [The Ecologically balanced crop rotations are basis of biological agriculture]. Visnyk ahrarnoi nauky, no. 2, pp.9-13. (in Ukrainian).

7. Boiko, P. I. \& Kovalenko, N. P. (2005) Naukovo obgruntovani sivozminy $i$ systema rilnyctva $u$ velykotovarnomu ghospodarstvi [Scientifically reasonable crop rotations and system of field-crop cultivation in large commodity economy]. Propozyciia, no. 6, pp. 38-42. (in Ukrainian).

8. Boiko, P. I. \& Kovalenko, N. P. (2008) Vysokotovarnye khoziaistva kak model racyonalnogho zemleyspolzovanyia [Highly commodity economies as model of the rational use of earth]. Aghrovisnyk Ukraiina, no. 1(24), pp. 24-27. (in Russian).

9. Demydenko, L. M. (2016) Orhanizatsiino-ekonomichni napriamy innovatsiinoho rozvytku silskohospodarskykh pidpryiemstv [Organizational and economic directions of innovative development of agricultural enterprises]. Naukovyi visnyk Khersonskoho derzhavnoho universytetu, vol. 20, pp. 72-75. (in Ukrainian).

10. Demydenko, O. V., Boiko, P. I., Blashchuk, M. I., Shapoval, I. S. \& Kovalenko N. P. (2019) Sivozminy ta rodiuchist chornozemu Livoberezhnoho Lisostepu: monohrafiia [Crop rotations and fertility of black earth of Left-bank Forest-steppe: monograph]. Smila: Chornobaivske KPP, 484 s. (in Ukrainian). 
11. Khodakivska, O. V. (2015) Ekolohizatsiia ahrarnoho vyrobnytstva: monohrafiia [Ecologization of agricultural production: monograph]. Kyiv: NNTs IAE, 350 s. (in Ukrainian).

12. Kovalenko, N. P. (2012) Ekolohichno zbalansovani sivozminy $v$ systemi alternatyvnoho zemlerobstva: istorychni aspekty [Ecologically balanced crop rotations in the system of alternative agriculture: historical aspects]. Ahroekolohichnyy zhurnal, no. 4, pp. 95-99. (in Ukrainian).

13. Kovalenko, N. P. (2014) Stanovlennia ta rozvytok naukovoorhanizatsiinykh osnov zastosuvannia vitchyznianykh sivozmin $u$ systemakh zemlerobstva (druha polovyna XIX - pochatok XXI st.): monohrafiia [Becoming and development of scientificallyorganizational bases of application of home crop rotations in the systems of agriculture (the second half of XIX is beginning of XXI of century): monograph]. Kyiv: TOV "Nilan-LTD”, 490 s. (in Ukrainian).

14. Kovalenko, N. P. (2016) Evoliutsiia vykorystannia znariad obrobitku gruntu $u$ vitchyznianomu zemlerobstvi [Evolution of the use of soil tillage tools in domestic agriculture]. History of science and technique, vol. 8, pp. 129-139. (in Ukrainian).

15. Kovalenko, N. P. (2017) Naukovi osnovy stanovlennia ta rozvytku zemlerobstva $v$ Ukraini [Scientific bases of becoming and development of agriculture are in Ukraine]. Visnyk ahrarnoi nauky, no. 5, pp. 60-66. (in Ukrainian).

16. Kovalova, O. V. (2008) Prohramno-tsilovyi pidkhid do upravlinnia ekoloho-spriamovanym silskohospodarskym vyrobnytstvom [A programmatic approach to the management of environmentallyoriented agricultural production]. Ekonomika APK. no. 2. pp. 105-110. (in Ukrainian).

17. Orekhivskyi, V. D. (2017) Evoliutsiia naukovykh osnov orhanichnoho zemlerobstva v Ukraini (druha polovyna XIX - pochatok XXI st.): monohrafiia [Evolution of the scientific basis of organic agriculture in Ukraine (the second half of XIX is beginning of XXI of century): monograph]. Vinnytsia: TOV "Nilan-LTD", $550 \mathrm{s.}$ (in Ukrainian).

18. Orekhivskyi, V. D. (2018) Evoliutsiia vprovadzhennia systemy orhanichnoho zemlerobstva $v \quad$ Pryvatnomu Pidpryiemstvi "Ahroekolohiia" $u$ druhii polovyni XX - na pochatku XXI stolit [Evolution of the organic farming system implementation in 
PE "Agroecology" in the second half of XX - at the beginning XXI of centuries]. Hileia, vol. 130, pp. 115-117. (in Ukrainian).

19. Orekhivskyi, V. D. (2018) Osoblyvosti rozvytku ahrarnykh pidpryiemstv $z$ vyrobnytstva orhanichnoi produktsii $v$ Ukraini (1990-ti - 2000-ni roky) [Features of development of agricultural enterprises for organic production in Ukraine $\left.\left(1990^{\mathrm{s}}-2000^{\mathrm{s}}\right)\right]$. Hileia, vol. 133, pp. 67-69. (in Ukrainian).

20. Pysarenko, V. M., Antonets, A. S. \& Pysarenko, P. V. (2017) Systema orhanichnoho zemlerobstva ahroekoloha Semena Antontsia [Organic farming system of agroecologist Semen Antonets]. Poltava: FOP Myron, I. A., 124 s. (in Ukrainian).

21. Pysarenko, V. M., Pysarenko, P. V. \& Ponomarenko, S. V. (2017) Orhanichne zemlerobstvo dlya pryvatnoho sektora [Organic agriculture is for a private sector]. Poltava: FOP Myron, I. A., $140 \mathrm{s.}$ (in Ukrainian).

22. Polehenka, M. A. (2017) Osoblyvosti innovatsiinoi diialnosti v ahropromyslovykh pidpryiemstvakh [Features of innovative activity in agro-industrial enterprises]. Ahrosvit, no. 6, pp. 49-54. (in Ukrainian).

23. Serediuk, Yu. I. \& Shmatkovska, T. O. (2015) Osoblyvosti innovatsii $v$ silskomu hospodarstvi [Features of innovation in agriculture]. Problemy formuvannia ta rozvytku innovatsiinoi infrastruktury: yevropeiskyi vektor - novi vyklyky ta mozhlyvosti: tezy dopovidei III Mizhnarodnoi naukovo-praktychnoi konferentsii (Ukraine, Lviv, May 14-16, 2015). Lviv: Vydavnytstvo Lvivskoi politekhniky, pp. 304-305. (in Ukrainian).

24. Shuvar, I. A., Sendetskyi, V. M. \& Bunchak, O. M. (2015) Vyrobnytstvo ta vykorystannia orhanichnykh dobryv: monohrafiia [Production and use of organic fertilizers: monograph]. IvanoFrankivsk: Symfoniia forte, 596 s. (in Ukrainian).

25. Sotnyk, I. M. \& Chumakova, M. M. (2013) Rynok ekolohichnykh innovatsii ta problemy yoho rozvytku [The ecoinnovation market and its development problems]. Mekhanizm rehuliuvannia ekonomiky, no. 3, pp. 38-48. (in Ukrainian).

26. Stetsyshyn, P. O., Pyndus, V. V. \& Rekunenko, V. V. (2011) Osnovy orhanichnoho vyrobnytstva [Fundamentals of organic production]. Vinnytsia: Nova knyha, 552 s. (in Ukrainian). 
27. Tsybuliak, A. H. (2016) Ekolohizatsiia silskoho hospodarstva $v$ umovakh hlobalizatsii [Ecologization of agriculture in the conditions of globalization]. Ahrosvit, no. 9, pp. 34-38. (in Ukrainian).

28. Zakon Ukrainy № 40-IV "Pro innovatsiinu diialnist" vid 5 hrudnia 2012 r. [Law of Ukraine no. 40-IV "On Innovative Activity" of December 5, 2012]. Retrieved from: https://zakon.rada.gov.ua/ laws/show/40-15 (accessed 30 September 2019). (in Ukrainian).

29. Zakon Ukrainy № 2496-VIII "Pro osnovni pryntsypy ta vymohy do orhanichnoho vyrobnytstva, obihu ta markuvannia orhanichnoi produktsii" vid 10 lypnia $2018 \mathrm{r}$. [Law of Ukraine no. 2496-VIII "On the basic principles and requirements for organic production, circulation and labeling of organic products" of July 10, 2018]. Retrieved from: https://zakon.rada.gov.ua/laws/show/2496-19 (accessed 30 September 2019). (in Ukrainian).

30. Zakon Ukrainy № 2697-VIII “"Pro Osnovni zasady (stratehiiu) derzhavnoi ekolohichnoi polityky Ukrainy na period do 2030 roku” vid 28 liutogo 2019 r. ["On the Fundamental Principles (Strategy) of the State Environmental Policy of Ukraine for the Period up to 2030" of February 28, 2019]. Retrieved from: https://zakon.rada.gov.ua/laws/show/2697-19 (accessed 30 September 2019). (in Ukrainian).

\section{Information about the author:} Natallia Kovalenko, Doctor of Historical Sciences, Senior Research, Chief Researcher of Science Sector of Institute of History of Agrarian

Science, Education and Technique, National Scientific Agricultural Library of National Academy of Agrarian Sciences of Ukraine, 10, Geroiv Oborony str., Kyiv, 03127, Ukraine ORCID ID: orcid.org/0000-0002-0996-0732 


\section{PECULIARITIES OF STATE REGULATION OF SCIENTIFIC RESEARCHES IN THE AGRICULTURAL SPHERE IN THE UKRAINIAN SOVIET SOCIALIST REPUBLIC DURING THE PERIOD OF RECONSTRUCTION (1943-1945)}

\section{Olena Korzun}

\section{INTRODUCTION}

Owing to military actions on the territory of The Ukrainian SSR (the Ukraine) in the World War II, great damage was caused to agricultural research institutions and farms: most of the establishments, stations, and fields were destroyed, and many of them were ruined and robbed ${ }^{1}$. Some research institutions were evacuated to the remote rear soon after the war outbreak, where they continued to carry out scientific experiments. The temporary occupation of the Ukraine's territory by the Nazi invaders destroyed the Republic's agriculture and completely disorganized the existing system of agricultural research. After scientists returned to the liberated territories of the Ukrainian SSR, they began solving organizational issues along with scientific tasks ${ }^{2}$. Excessive work of scientists, who managed to eliminate negative consequences of Nazi's impact on the Ukrainian SSR by restoring industry research and the reconstruction of agricultural production within the shortest span of time, ensured the further effective development of agriculture in the country.

Therefore, measuring the contribution of agricultural research institutions during the reconstruction period and production process of the Ukrainian SSR within 1943-1945 can be considered as a powerful basis for the impartial display of the past and effective planning of

${ }^{1}$ Verhunov, V. A. (2012). Sil's 'kohospodars'ka doslidna sprava v Ukrayini vid zarodzhennya do akademichnoho isnuvannya: orhanizatsiynyy aspekt. [Agricultural research in Ukraine from birth to academic existence: an organizational aspect.] Kyyiv: Ahrarna nauka. P. 58.

${ }^{2}$ Verhunov, V. A. \& Khyzhnyak, V. P. (2004). Ukrayins'ki naukovo-doslidni sil's'kohospodars'ki zaklady $\mathrm{v}$ roky Velykoyi Vitchyznyanoyi viyny. [Ukrainian agricultural research institutions during the Great Patriotic War.] Istorychni zapysky: zbirnyk naukovykh prats'. 1. P. 20. 
perspective agricultural production in Ukraine. It is important to clarify the peculiarities of state regulation of industrial scientific researches in accordance with different areas of agricultural production in the Ukrainian SSR. In particular, they embrace determining scientific provision of spheres such as land, crop, fruit farming, viticulture and winemaking; defining the ways of reconstruction of scientific researches in the sphere of breeding and seed crops; specifying the ways of reproduction of scientific and organizational process in agronomic amelioration and mechanization of agriculture, as well as scientific basis for reconstructive processes in technical husbandry.

\section{The peculiarities of administering agricultural researches in Ukrainian SSR during the period of reconstruction}

During 1941-1945, industrial research institutions suffered great damage - most of the institutions, stations, and fields were destroyed, others were extremely ruined and robbed. Soon after the start of military actions, some research institutions were evacuated to the remote rear, where they continued to carry out scientific researches. After the return of institutions, scientific stations, and fields to the liberated territories of the Ukrainian SSR, scientists began solving organizational issues along with scientific tasks. Within 1943-1945 excessive free work of scientists, who managed to eliminate negative consequences of Nazi impact on the Ukrainian SSR by means of restoring industry research and the reconstruction of agricultural production within the shortest period, ensured the further effective development of industrial science and practice.

Even before World War II, Ukrainian farmers boasted of the functionally extensive network of agricultural research institutions, which consisted of 15 institutes, 34 research stations, 16 research fields, and 62 experimental stations, which were under different subordination $^{3}$. Particularly, they subordinated to the People's Commissariat of Agriculture and the People's Commissariat of the food

3 Verhunov, V. A. \& Khyzhnyak, V. P. (2004). Ukrayins'ki naukovo-doslidni sil's'kohospodars'ki zaklady V roky Velykoyi Vitchyznyanoyi viyny. [Ukrainian agricultural research institutions during the Great Patriotic War.] Istorychni zapysky: zbirnyk naukovykh prats'. 1. P. 20. 
industry in Ukraine, and the People's Commissariat of Agriculture in the Ukrainian SSR. Besides, several agricultural training departments functioned at universities and institutions of the People's Commissariat of Education. The issues concerning the scientific provision of agricultural production were also solved by scholars of the Agriculture Department, Academy of Sciences of the Ukrainian SSR.

Before the Nazi occupation, the work of Ukrainian SSR research institutions' was systematized according to the main areas: agriculture and crop production, breeding and seed production, agronomic amelioration, mechanization and electrification of agriculture, fruit growing, viticulture and winemaking, animal husbandry, etc. This network was presented by well-organized research institutions, which were equipped with laboratories, experimental centers, animal farms, collection nurseries, forest and fruit plantations, etc. At the beginning of 1941, the overall number of scientific staff in institutes, experimental stations and fields were approximately 520 senior researchers with a budget of more than 17 million rubles ${ }^{4}$. The agricultural scientists achieved considerable global success, particularly concerning the effectiveness of agricultural actions, fertilizers, melioration, actions connected with pest control and crops' diseases. Together with achievements that agricultural science made in the early 1940s, there were also shortcomings, which included the imperfection of its organization and management system. Research institutions were separated and had no proper unified scientific and methodological center, which would manage and direct all the work of the network according to the appropriate scientific plan.

As the Ukrainian territories were liberated from the Nazi invaders, the Central Committee of Communist Party and the Council of People's Commissars of the Ukrainian SSR adopted resolutions on restoring the work of the Ukrainian SSR research institutions. The first document was the resolution of the Council of People's Commissars of the Ukrainian SSR № 545 “On the restoration of the work of agricultural

${ }^{4}$ Verhunov, V. A. (red.). (2012). Sil's'ke hospodarstvo URSR ta yoho naukove zabezpechennya u 1940-1946 rokakh: zb. dok. i materialiv. [USSR agriculture and its scientific support in 1940-1946: coll. dock. and materials.] NAAN, DNS·HB, TSDAVO Ukrayiny. Kyyiv: Nilan-LTD. P. 34-36. 
research institutions of the Ukrainian SSR", dated December 13, $1943^{5}$. In accordance with this resolution, the work of the following institutions was reconstructed: the Central scientific agricultural library and five research institutes (The Ukrainian research Institute of socialist agriculture (Kharkiv), The Ukrainian research Institute of agricultural mechanization, The Ukrainian research Institute of animal husbandry, The Ukrainian research Institute of experimental veterinary medicine, The Ukrainian branch of the Institute of fodder), eight research stations (Krasnograd breeding and experimental station, Experimental centres of the Ukrainian Research Institute of agricultural mechanization, the Ukrainian research Institute of animal husbandry, the Ukrainian research Institute of experimental veterinary medicine, Chernihiv animal husbandry research station, Ukrainian poultry research station, Kharkiv and Stalin vegetable and potato stations).

The following resolutions of the Council of People's Commissars of the Ukrainian SSR on the reconstruction of the Ukrainian scientific and research activities, approved in 1944 (№ 232 of March 18, № 495 of May 15, № 678 of June 17), restored the activities of 59 research institutions $^{6}$. To them belong 1 library, 10 scientific and research institutes, 26 research stations, 15 research fields, 7 experimental stations. In the Western regions of the Ukrainian SSR, it was planned to organize new research institutions of national importance. In particular, the work of Lviv research station of field breeding and experimental fields in Drohobych and Stanislavsky areas of the Ukrainian SSR started for the purpose of scientific provision of Lviv region agriculture based on the resolution of the Ukrainian SSR Council of People's Commissars № 36-10 of March 25, 1945 on the organization of research institutions in the Western areas of the Ukrainian SSR in connection with the resolution of the Council of People's Commissars of the Ukrainian SSR № 775 of May 12, 1945. In scientific and

${ }^{5}$ Verhunov, V. A. (red.). (2012). Sil's'ke hospodarstvo URSR ta yoho naukove zabezpechennya u 1940-1946 rokakh: zb. dok. i materialiv. [USSR agriculture and its scientific support in 1940-1946: coll. dock. and materials.] NAAN, DNS·HB, TSDAVO Ukrayiny. Kyyiv: Nilan-LTD. P. 19.

${ }^{6}$ Verhunov, V. A. (red.). (2012). Sil's'ke hospodarstvo URSR ta yoho naukove zabezpechennya u 1940-1946 rokakh: zb. dok. i materialiv. [USSR agriculture and its scientific support in 1940-1946: coll. dock. and materials.] NAAN, DNS·HB, TSDAVO Ukrayiny. Kyyiv: Nilan-LTD. P. 20. 
research establishments, the departments such as agricultural technology and chemistry, vegetable breeding, breeding and seed, fodder production, plant protection, economics and organization of agriculture were organized to conduct complex, scientific and research experiments in the field of agriculture. Besides, the laboratory of agricultural chemistry, soil microbiology, and agricultural agrometeorology was created. However, during the occupation, a large number of experimental stations were destroyed. In particular, in 1941 there were 42 establishments, and in 1944 there were only 7. Nevertheless, on August 1, 1944, 94\% of research institutes, stations and fields were restored, in comparison with 1941.

So, in 1944 the network of the Ukrainian SSR scientific and research institutions was systematized in the following directions: agriculture and crop production, husbandry and seed production, agronomic melioration, mechanization and electrification of agriculture, fruit growing, viticulture and winemaking, animal husbandry, etc. The following institutions focused on the agriculture and crop production, breeding and seed production: 1) The Ukrainian research Institute of socialist agriculture (Kyiv) with a network of experimental stations, fields and research points (Polissia scientific and research station of field husbandry, The Kazarovychi scientific and research station of grassland culture, Sarny scientific and research station of the swamp reclamation, The Chernivtsi scientific and research station of field husbandry, Lanovtsy scientific and research breeding station, Kyiv, Kharkiv, Stalin, Odessa breeding vegetable and potato stations and Skvyra experimental breeding plot, Korosten, Chartoriy and Gradizh experimental plots, Buchan and Sviatoshyn experimental stations); 2) The Ukrainian scientific and research Institute of socialist agriculture (Kharkiv) with a network of experimental stations, fields and research centres (Chervonograd breeding and experimental station, Valkiv experimental plot); 3) Ukrainian scientific and research Institute of grain farming (Dnipropetrovsk) with a network of experimental stations, fields and research centres (Erastiv, Synelnikiv, Luxemburg, Genichesk, Starobilske experimental fields, Olexandrovsk scientific and research watermelon experimental center, Odessa scientific and research station of crop breeding, Zherebkiv scientific and research station of crop 
breeding, Ukrainian scientific and research station of oil crops, Ukrainian scientific and research station of rice growing) ${ }^{7}$.

According to the sphere of agromelioration, in the following instituitions carried out researches: 1) Ukrainian scientific and research Institute of agro-forestry-melioration (Kharkiv) with a network of research stations and experimental centres (Tsyurupinsk scientific and research station of sands reclamation of the Lower Dnieper (Tsyurupinsk), Mariupol and Volodymyr agro-forestry-melioration scientific and research stations, Guerrilla agroforestry-melioration experimental station, Prydesnyansk experimental station of soil erosion); 2) Ukrainian scientific and research Institute of water engineering and melioration (Kyiv) with a network of experimental stations and fields (Bril scientific and research irrigation station, Sumy, Panfilov, Borovsk and Kamenske on the Dnieper experimental fields). Mechanization and electrification of agriculture was under scrutiny in: 1) Ukrainian scientific and research Institute of mechanization of agriculture (Kyiv) with subordinate research stations: Kharkiv scientific and research station of mechanization (Kharkiv), Akymivka scientific and research station of mechanization (Akimivka, Zaporizhia region) ${ }^{8}$.

In the direction of fruit growing, viticulture and winemaking research was carried out by: 1) Ukrainian research Institute of fruit growing (Kitaevo, m. Kiev) with subordinate experimental stations and reference points (Mlievskaya, Melitopol research station of fruit growing, Krasnokutsky, Yamsky and Vozdvizhensky extended reference points); 2) Ukrainian research Institute of viticulture and winemaking (Odessa). In the direction of animal husbandry worked: 1) Ukrainian research Institute of animal husbandry (n. Kharkiv) with subordinate research stations (Chernihiv research station of animal husbandry, Chernihiv research station of poultry (Borki, Kharkiv region, Ukrainian research station of beekeeping (Merefa, Kharkiv

7 (1944). Dodatok do Nakazu № 1147 NKZS URSR pro vidnovlennya ta stan roboty naukovo-doslidnykh ustanov za 1944 r. [Addendum to the Order \# 1147 of the NKVD of the USSR on the restoration and state of operation of research institutions for 1944] TSDAVO Ukrayiny. F. 27. Op. 17. Spr. 1053. Ark. 292-293.

${ }^{8}$ Verhunov, V. A. (red.). (2012). Sil's'ke hospodarstvo URSR ta yoho naukove zabezpechennya u 1940-1946 rokakh: zb. dok. i materialiv. [USSR agriculture and its scientific support in 1940-1946: coll. dock. and materials.] NAAN, DNS·HB, TSDAVO Ukrayiny. Kyyiv: Nilan-LTD. P. 22. 
region), Ukrainian research station of fish farming (Sultanivka, Kyiv region); 2) Ukrainian research Institute of experimental veterinary medicine (Kharkiv) ${ }^{9}$.

The following institutions conducted the researches in the sphere of fruit farming, viticulture and winemaking: 1) Ukrainian scientific and research Institute of fruit farming (Kitaevo, Kyiv) with subordinate research stations and experimental centers (Mliiv, Melitopol scientific and research station of fruit growing, Krasnokutsk, Yam and Vozdvyzhensk extended experimental centers); 2) Ukrainian scientific and research Institute of viticulture and winemaking (Odessa). The sphere of animal husbandry was under scrutiny in: 1) Ukrainian scientific and research Institute of animal husbandry (Kharkiv) with subordinate research stations (Chernihiv scientific and research station of animal husbandry, Chernihiv research station of poultry farming (Borky, Kharkiv region, The Ukrainian scientific and research station for apiculture (Merefa, Kharkiv region), The Ukrainian scientific and research station for fishery (Sultanivka, Kyiv region); 2) The Ukrainian scientific and research Institute of experimental veterinary medicine (Kharkiv) .

During World War II, the staff members of the research institutions were affected deeply. In August 1, 1944, there were only 184 senior researchers in the restored network, which made up 35\% in comparison with 1941. They included 19 chief executives and professors, 66 candidates of agricultural sciences and 85 people with a scientific degree. August, 1, 1944, there were professional staff members such as chief executive officers, their deputies of scientific work and chief accountants. However, the average quantity of staff members reached $62 \%$ in the Ukrainian scientific and research institutions. It was planned to meet the scientific staff members needs through extending full-time and part-time postgraduate studies, as well as upgrading current employees' skills. By the end of 1944, it was intended to begin the training program of 70 scientific staff members, among which 55 were be extramural students.

9 (1944). Dodatok do Nakazu № 1147 NKZS URSR pro vidnovlennya ta stan roboty naukovo-doslidnykh ustanov za 1944 r. [Addendum to the Order № 1147 of the NKVD of the USSR on the restoration and state of operation of research institutions for 1944] TSDAVO Ukrayiny. F. 27. Op. 17. Spr. 1053. Ark. 293. 
The department of Ukrainian scientific and research institutions, as the highest scientific institution and at the same time scientific, methodical and coordination center of agricultural science in the country, provided the management of agricultural research in the period of reconstruction. The formation of the Ukrainian Republican Scientific Council, as a body that developed the main recommendations for solving important tasks within scientific, methodological and organizational sphere was started in order to strengthen the management of the agricultural research field. The aforementioned Scientific Council was to coordinate scientific and academic plans of all scientific and research institutions despite their subordination, in order to provide the unified methodical direction of the scientific work. There was also a perspective in adjusting academic forms of management in accordance with principles of the Academy of Sciences of the Ukrainian SSR.

In 1944, scientific and methodological plan of scientific and research institutions of the Ukrainian SSR network mainly duplicated the theme of the pre-war period. It is quite understandable, since the main problems solved in the early 1940s in the sphere of agricultural development, remained significantly relevant both in the wartime and during the period of reconstruction. The main topics, developed in the scientific and research institutions, were long-term ones. Annually the scientific and research institutions, stations and fields, solved problems connected with the requirements of socialist agricultural production of a certain span of time. Thus, such tasks as increasing soil fertility, crop yields and improving product quality, the creation of new varieties of grain and industrial crops, the introduction of improved agricultural techniques, remained relevant. The defining criteria in solving these problems were the basic requirements to production set by operational organizations of collective and state farms before science. The main requirements to the production, which were stated by collective and state farms, appeared to be defining criteria during solving these problems ${ }^{10}$. While planning and carrying out scientific research, special attention was paid to the main resolutions of People's Commissars of

10 Kalachykov, O. T. (1945). Dosyahnennya y zavdannya naukovo-doslidnykh zakladiv Narkomzemu Ukrayiny .[and tasks of the National Research Commissions of Ukraine.] Sil's 'ke hospodarstvo Ukrayiny. 1. P. 60. 
the Ukrainian SSR in 1944: "On improving seed production of grain crops", "On improving seed production of potatoes", "On improving breeding and seed production of vegetable and melon crops", "On the development of animal husbandry", "On the development of fruit growing", etc.

The scientific and academic plan of conducting researches by the Ukrainian SSR scientific and research institutions, approved for 1944-1945, comprised 110 topics, which united 7-8 key tasks, and were divided according to the main groups: land husbandry embraced 42 topics, mechanization - 9 topics, animal husbandry and experimental veterinary - 19 topics; fruit farming and breeding of potatoes -26 topics; agronomic melioration -14 topics.

In particular, it was necessary to develop methods and techniques of intensive herd restoration of working and productive cattle of all kinds in the cattle breeding. At the same time, it was also significant to improve breed structure; to apply the main achievements in eliminating epizootics and other diseases of agricultural animals and poultry, to destroy the nidi of diseases left after fascist occupation; to elaborate the system of actions for apiculture and fishery development in collective farms ${ }^{11}$.

It was expected to explore simplified but highly productive structures of sowing, harvesting and winnowing machines; develop the system of economic usage of fuel and lubricating materials; prepare technical characteristics of agricultural machines and engines samples for their effective usage; broadly implement positive results of testing agricultural machines and household production devices. Restoration of destroyed forest protective hedges, as well as pond farms and irrigated agriculture was introduced in the sphere of agricultural melioration.

In agriculture and crop production, fruit farming, viticulture and winemaking, it was necessary to develop a set of main agrotechnical measures in order to restore beet farming, eliminate the negative consequences of violations of crop rotations, to make efforts to restore the grain economy, to reconstruct elite and reproductive seeds of

11 Verhunov, V. A. (red.). (2012). Sil's'ke hospodarstvo URSR ta yoho naukove zabezpechennya u 1940-1946 rokakh: zb. dok. i materialiv. [USSR agriculture and its scientific support in 1940-1946: coll. dock. and materials.] NAAN, DNS·HB, TSDAVO Ukrayiny. Kyyiv: Nilan-LTD. P. 27. 
high-yielding varieties of grains, vegetables and herbs; to promote the production of high yields of potatoes and vegetables. The exploration of effective methods of growing high yield-rubber, in particular Koksagiz, as well as oilseeds and yarn crops as an important strategic agricultural raw material; agricultural rice growing techniques for collective farms was necessary. This complex also included various methods of using artificial fertilizer, various composts, green fertilizers and the most intensive using of substances, which contain nitrogenfixing bacteria (nitrogen backterin) and nodule bacteria (nitragin) ${ }^{12}$. Another task was to develop and apply agricultural production and storage methods of biologically bound nitrogen as an additive to nitrogen fertilizers; to improve the restoration of fruit plantations, berries and vineyards in the Ukrainian SSR; to develop a system for combating potato cancer, viral diseases of industrial crops, in particular tobacco and rubber plants.

Suffice it to mention the productive work of the Academy of Sciences of the Ukrainian SSR scientists, aimed at the needs of agriculture. For that purpose at the beginning of 1945, the solution to the problem of creation the network of institutions in its structure aimed at solving agricultural problems. April, 20, 1945, the Presidency of the Academy of sciences of the Ukrainian SSR approved of the decree with regard to creation the Commission on organization the Department of Agricultural Sciences of the Ukrainian $\mathrm{SSR}^{13}$. The following distinguished scholars became its members: M. Gryshko, O. Dushechkin, associate member V. Starchenko (the Minister of agriculture of the Ukrainian SSR), P. Vlasiuk, P. Pogrebnyak, Ya. Roll, L. Rubenchik, full professor O. Markevich.

In the mid 1945, the Presidency of the Academy of Sciences of the Ukrainian SSR has considered the Commission's proposals on

${ }^{12}$ Verhunov, V. A. (red.). (2012). Sil's'ke hospodarstvo URSR ta yoho naukove zabezpechennya u 1940-1946 rokakh: zb. dok. i materialiv. [USSR agriculture and its scientific support in 1940-1946: coll. dock. and materials.] NAAN, DNS·HB, TSDAVO Ukrayiny. Kyyiv: Nilan-LTD. P 26.

${ }^{13}$ Zubets', M. V. (red.). (2008). Viddil sil's 'kohospodars'kykh nauk Natsional 'noyi akademiyi nauk Ukrayiny (1945-1956): zb. dok. $i$ materialiv. [Department of Agricultural Sciences of the National Academy of Sciences of Ukraine (1945-1956): Coll. dock. and materials.] UAAN, DNS·HB UAAN, NAN Ukrayiny, NBU im. V. I. Vernads'koho. Kyyiv: Ahrarna nauka. P. 21. 
formation of the Department of Agricultural Sciences of the following institutions:

1. The Institute of soil science (based on the Laboratory of soil science and the Department of soil Microbiology of the Institute of Microbiology).

2. The Institute of plant physiology and agrochemistry (based on the Department of plant physiology of the Institute of botany).

3. The Institute of entomology, parasitology and phytopathology (based on the departments of entomology and parasitology of the institute of zoology).

4. The Institute of genetics and selection (on the basis of departments of genetics and selection of Institute of Zoology and selection).

5. The Institute of crop production (on the basis of the existing Institute of socialist agriculture of the Ukrainian SSR (Kharkiv).

6. The Institute of forestry (on the basis of the Department of ecology of the Botanical garden and experimental forestry).

7. The Institute of agricultural mechanics (based on the Laboratory of agricultural engineering and problems of agricultural mechanics).

Besides, the Commission requested the Presidency to involve the following academicians to the Department of agricultural Sciences of the Academy of Sciences of the Ukrainian SSR: T. Lysenko, A. Sapegin, V. Pospelov, O. Sokolovsky, M. Gryshko, O. Dushechkin, V. Yuriev; associate members: E. Zverezomb-Zubovskiy, P. Vlasyuk, P. Vasylenko, P. Pogrebniak, P. Sviridenko, Y. Modilevskiy, M. Popov. Moreover, another request was aimed at addressing the Council of People's Commissars of the Ukrainian SSR to conduct additional elections of full and associate members for different specialties: crop production, agrophysiology, agricultural mechanics, plant breeding, genetics, forestry (full members); soil science, crop production, agrochemistry, phytopathology, parasitology, plant breeding, animal breeding, technology and primary processing of agricultural products (associate members) ${ }^{14}$.

${ }^{14}$ Zubets', M. V. (red.). (2008). Viddil sil's 'kohospodars'kykh nauk Natsional'noyi akademiyi nauk Ukrayiny (1945-1956): zb. dok. $i$ materialiv. [Department of Agricultural Sciences of the National Academy of Sciences of Ukraine (1945-1956): Coll. dock. and materials.] UAAN, DNS·HB UAAN, NAN Ukrayiny, NBU im. V. I. Vernads'koho. Kyyiv: Ahrarna nauka. PP. 25-26. 
In August 24, 1945, the Presidency allowed to form the Department of agricultural Sciences and its institutions in the structure of the Academy of Sciences of the Ukrainian SSR. Those institutions included The Institute of physiology of agricultural plants and agrochemistry, The Institute of genetics and selection, The Institute of entomology and phytopathology, Institute of forestry. The newly formed department the laboratory of mechanical engineering and agricultural mechanics also included the Department of Technical Sciences and the laboratory of soil science with the Botanical garden ${ }^{15}$.

In October, 1945, the Council of People's Commissars of the Ukrainian SSR and the Central Committee of Communist Party adopted a resolution on the formation of the Department of Agricultural Sciences in the structure of the Ukrainian SSR Academy of Sciences with the purpose of creating a single governing body of agricultural science for the fundamental solution to the theoretical issues related to improving soil fertility, creation of new high-productive crops, development of an effective system of plant nutrition, as well as for solving problems of agricultural engineering and tractor industry. The aim of the Department of Agricultural Sciences of the Academy of Sciences of the Ukrainian SSR was to solve urgent theoretical problems in the agricultural science, which were not feasible for separate scientific and research institutions and experimental stations. Besides, another aim was to implement widely and efficiently the results of scientists theoretical developments in agricultural production. ${ }^{16}$

\section{The reconstruction of scientific and organizational process in the agriculture of the Ukrainian SSR}

During the German occupation, the national economy in all regions of the Ukrainian SSR underwent massive destruction. The population living in the zone of military operations was involved in

${ }^{15}$ Verhunov, V. A. (red.). (2012). Sil's'ke hospodarstvo URSR ta yoho naukove zabezpechennya u 1940-1946 rokakh: zb. dok. i materialiv. [USSR agriculture and its scientific support in 1940-1946: coll. dock. and materials.] NAAN, DNS·HB, TSDAVO Ukrayiny. Kyyiv: Nilan-LTD. P. 31.

16 (1948). Vazhneyshye reshenyya po sel'skomu khozyaystvu za 1938-1946 rr. [The most important decisions on agriculture for 1938-1946] Moskva: Sel'khozgyz. P. 29. 
hard slave work while the agricultural resources were drastically exploited $^{17}$. On the one hand, great damage was caused to the agriculture of the country by the predatory policy of the invaders and destructive measures during retreat; on the other hand, incorporation of agricultural resources for the military needs and evacuation of scientific and research institutions to the East ${ }^{18}$. The losses of the agricultural sector were significant: the mass destruction of long-term experiments in the experimental fields, stations and collective farms, as well as a significant reduction in acreage led to a rapid decline in crop yields ${ }^{19}$ and livestock in animal husbandry ${ }^{20}$. In general, of all the Soviet Union the Ukrainian SSR suffered the greatest damage, namely 285 billion rubles $^{21}$ or $42 \%{ }^{22}$.

17 Torzecki, R. (1993). Polacy I Ukraincy. Sprawa ukrainska w czasie II wojny swiatowej na terenie II Rzeczypospolitej.[Poles and Ukrainians. The Ukrainian case during World War II in the territory of the Second Polish Republic] Warszawa: Wydawnictwo naukowe PWN. P. 39.

18 Vlasenko, S. (2010). Naslidky nimets'koyi okupatsiyi dlya sil's'koho hospodarstva viys'kovoyi zony Ukrayiny (za dokumentamy derzhavnykh arkhiviv Ukrayiny). [Consequences of German occupation for agriculture of the military zone of Ukraine (according to documents of the state archives of Ukraine)] Kyyiv. P. 100.

19 (1945). Dopovidni zapysky i dovidky pro rezul'taty perevirky spivrobitnykamy NKZS URSR stanu tvarynnytstva v kolhospakh URSR (za oblastyamy) u 1945 r. [Additional notes and certificates on the results of the examination of the stock-raising of the livestock in the collective farms of the Ukrainian SSR (by oblasts) in 1945] TSDAVO Ukrayiny. F. R-27. Op. 17. Spr. 8886. Ark. 6.

20 (1945). Dopovid' Narkoma zemlerobstva URSR H.P. Butenka na Pershomu respublikans'komu zasidanni peredovykiv produktyvnoho tvarynnytstva i konyarstva kolhospiv URSR vid 24-27 hrudnya 1945 r. [Report of the People's Commissar of Agriculture of the Ukrainian SSR GP Butenko at the First Republican Meeting of the Leaders of Productive Livestock and Horse Breeding of the Collective Farms of the USSR from December 24-27, 1945.] TSDAVO Ukrayiny. F. R-27. Op. 17. Spr. 8882. Ark. 7.

21 Torzecki, R. (1994) Die Rolle der Zusammenarbeit mit der deutschen Besatzungsmacht in der Ukraine für deren Okkupationspolitik [The role of cooperation with the German representative power in Ukraine for its occupation policy] Europa unterm Hakenkreuz. Okkupation und Kollaboration 1938-1945, Achtbändige Dokumentenedition. [Europe under the swastika. Occupation and collaboration 1938 1945, eight-volume document edition] Bd. 1, Berlin/Heidelberg, P. 239-273.

${ }^{22}$ Ovsiyenko, A. M. (2010). Osoblyvosti finansovoyi systemy Ukrayins'koyi RSR u vidbudovchyy period (druha polovyna 40-kh - pochatok 50-kh rokiv XX st.). [Features of the financial system of the Ukrainian SSR in the reconstruction period (the second half of the 1940s - the beginning of the 1950s).] Kyyiv. P. 27. 
As a consequence of Soviet and German troops retreat and offensive fighting and bombing, 27910 collective farms, 872 state farms, 1300 machine and tractor stations were turned into ruins. In fact, the material and technical base of all branches of agricultural production of the Ukrainian SSR was completely destroyed: 56128 tractors, 24128 combines, 1187 different agricultural machines. After the liberation, one third of tractors remained in the agriculture of the country in comparison with pre-war level, the quantity of agricultural machines reduced 3 times, and the number of combine-harvesting machines became 5 times less. Retreating under the blows of the Soviet troops, the Nazis tried to take food and raw materials with them to the west. During the period of occupation, 4415 thousand tons of grain and flour, 1310 thousand tons of potatoes, vegetables and fruits, 458 tons of hay were shipped from the collective farms of the Ukrainian SSR to Germany ${ }^{23}$.

In general during 1941-1945, 1808 thousand houses were destroyed in the villages, 7594 thousand cattle heads were slaughtered and exported to Germany, 9333 thousand swine, 7317 thousand sheep and goats, 59297 thousand poultry, 3311 thousand horses; 17307 thousand tons of grain were either destroyed or exported. In the collective farms of the Ukrainian SSR, more than 230 thousand buildings were ruined, 18 million hectares of crops, 144 thousand hectares of gardens and vineyards were cut down as a result of military operations and following the instructions of both Soviet and German authorities ${ }^{24}$.

As for the animal husbandry, the destruction of the breeding business was extremely disastrous. At the beginning of 1940, the center of breeding cattle reproduction was formed and functioned successfully in the Ukrainian SSR, which both satisfied Republican needs and allowed to deliver breeding cattle to other areas and the republics of the USSR. In 1941, breeding cattle was raised by 13 state breeding nurseries and 687 breeding farms, pigs -4 state breeding nurseries and

${ }^{23}$ Verhunov, V. A. (red.). (2012). Sil's'ke hospodarstvo URSR ta yoho naukove zabezpechennya u 1940-1946 rokakh: zb. dok. i materialiv. [USSR agriculture and its scientific support in 1940-1946: coll. dock. and materials.] NAAN, DNS·HB, TSDAVO Ukrayiny. Kyyiv: Nilan-LTD. P. 9.

24 (1975). Ukraynskaya SSR v Velykoy Otechestvennoy voyne Sovetskoho Soyuza 1941-1945 rr. [The Ukrainian SSR in the Great Patriotic War of the Soviet Union 1941-1945.] V 3-kh t. T. 3. Kyev: Polytyzdat. P. 155-156. 
699 breeding farms, horses - 3 state breeding nurseries and 360 breeding farms, poultry - 257 breeding farms. There was also a network of breeding animal farms within collective farms. The significant amount of the breeding stock was lost during the evacuation in the first war months, and the rest was looted, slaughtered or taken by the Nazi invaders to Germany; as a result, at the time of the liberation of the Ukrainian SSR breeding stock was actually destroyed.

During the period of occupation, the fodder base of the animal husbandry also suffered damage. The sowing of fodder crops was not carried out, so that the acreage of perennial grasses was insignificant, which led to an unsatisfactory state of the land on the basis of liquefaction and contamination of crops. In the left-bank regions of the Ukrainian SSR, liberated in 1943, only $20 \%$ of the areas were sown with fodder crops in comparison with 1940, including perennial grasses - 31\%, annual grasses $-13.9 \%$, root crops $-10.1 \%$. The situation was also complicated by the complete destruction of seed production of fodder $\mathrm{crops}^{25}$.

The reconstruction of the Ukrainian agriculture began in winter 1943 immediately after the liberation of some of its territories. Party and state authorities were guided by the resolution of the Council of People's Commissars of the Ukrainian SSR and the Central Committee of Communist Party "On measures of restoration and reconstruction of agricultural machines and tractors stations and collective farms in areas liberated from Nazi invaders" from January 23, 1943. According to this resolution, local party and Soviet authorities were obliged to restore the work of the district agricultural departments and direct their efforts to the restoration of collective farms and the organization of agricultural work. They also collected and made stocktaking of all collective farm property and inventory, registered all working and productive cattle, allocated it on farms, and provided proper care.

The task of restoring agricultural production and eliminating the negative consequences of the violation and destruction of experiments was set to scientific and research institutions in order to overcome the consequences of German invasive management in the Ukrainian SSR.

${ }^{25}$ Verhunov, V. A. (red.). (2012). Sil's'ke hospodarstvo URSR ta yoho naukove zabezpechennya u 1940-1946 rokakh: zb. dok. i materialiv. [USSR agriculture and its scientific support in 1940-1946: coll. dock. and materials.] NAAN, DNS·HB, TSDAVO Ukrayiny. Kyyiv: Nilan-LTD. P. 10. 
It particularly referred to the experimental stations organized in Ukrainian SSR collective farms, the quantity of which decreased by six times: from 42 in 1941 to 7 in $1944 .^{26}$ Also it was crucial to breed elite and to reproduce the seeds of high-yielding grades of grain, vegetable cultures and long-term legumes ${ }^{27}$.

According to the resolution of the Council of People's Commissars of the Ukrainian SSR "On the state plan of the Ukrainian SSR agriculture in 1945 ", an important measure to ensure planned crops planting was their allocation in the fields of crop rotation taking into account the effective predecessors, while avoiding overload of technical and arable crops of farm fields ${ }^{28}$. In the third chapter of this resolution "On measures to increase yields", special attention was focused on the rapid restoration of crop rotations destroyed by the German invaders, as well as their further effective implementation in the collective farms of the Ukrainian SSR. The restoration of margins of the arable fields and removing boundary marks, making and specifying the plan of transition to scientifically proved agrotechnical actions became very crucial in 1945.

According to this resolution, in the spring of 1945, crops allocation and fallow fields were carried out in accordance with the adopted crops alteration/rotation for effective soil cultivation through crop rotations. Restoration and introduction of crop rotations were carried out primarily in district seed farms, district seed nurseries for perennial grasses and collective farms with large livestock farms, which lacked forage lands $\mathrm{s}^{29}$. They also established seed-breeding plots for legumes

26 (1946). Spravka o sostoyanyy roboty Ukraynskoho nauchno-yssledovatel'skoho ynstytuta zernovoho khozyaystva ym. V.V. Kuybysheva za 1946 h. [Information on the status of robots of the Ukrainian Grain Research Institute named by V.V. Kuibyshev for 1946] TSDAVO Ukrayiny. F. 27. Op. 17. Spr. 40. Ark. 387.

27 (1945). Merezha naukovo-doslidnykh ustanov NKZS URSR za 1945 r. [Network of Research Institutes of the NKVD of the USSR for 1945] TSDAVO Ukrayiny. F. 27. Op. 17. Spr. 1728. Ark. 144.

${ }^{28}$ Perekhrest, O. H. (2011). Sil's'ke hospodarstvo Ukrayiny v 1943-1945 rr.: problemy ta rezul'taty vidbudovy. Ukrayina $v$ druhiy svitoviy viyni: pohlyad $z$ XXI st.: istorychni narysy. [Agriculture of Ukraine in 1943-1945: Problems and results of reconstruction. Ukraine in the Second World War: A View from the 21st Century: Historical Essays] Kyyiv: Naukova dumka. P. 563.

29 (1945). Postanovy RNK URSR i TSK KP(b)U shchodo diyal'nosti naukovodoslidnykh ustanov u 1945 r. [Resolutions of the RNA of the USSR and the Central Committee of the Communist Party of Ukraine (b) U concerning the activities of research institutions in 1945] TSDAVO Ukrayiny. F. 27. Op. 17. Spr. 49. Ark. 133. 
and biennial cereal grasses on at least $1 \%$ of the arable land to enable the collective farms to sow the field of perennial legumes seeds with their own seeds within the following 2-3 years. The resolution of the Council of People's Commissars of the Ukrainian SSR "On measures of improvement the introduction and development of crop rotations in collective farms" of June 21, 1945 was of great significance ${ }^{30}$.

In 1943, using imported from Bashkiria, Kuibyshev, Ulyanovsk and other regions seeds of elite varieties of vegetable crops, scientists grew and harvested 210 tons of seed material of these crops, which together with the return of 52 tons of elite and improved seeds of Ukrainian varieties, evacuated in 1941, provided the formation of seed-breeding plots on the area of 12, 627 hectares in the liberated territories in $1944^{31}$. Exported from the Ukrainian SSR elite seeds, preserved and reproduced in the remote areas of the Ukrainian SSR, provided a rapid recovery of seed vegetable crops. 264 varieties out of 287 existing in the Ukrainian SSR before the World War II, were reproduced in 1946. In these years, the area of seedbreeding plots of vegetable and melon crops grew rapidly.

The lack of the necessary laboratory equipment was a problem that prevented the extension of scientific and research work during 1943-1945. In pre-war time, the separate organizations provided experimental process with laboratory glass, chemical reagents, filter paper, analytical and technical scales, microscopes, calorimeters, psychrometers, thermometers usual and ground, etc. ${ }^{32}$ These material resources were severely destroyed during the occupation and only a small amount of them, evacuated to the Eastern regions of the Ukrainian SSR, returned to the scientific staff of the scientific and research institutions and experimental stations; nevertheless, this number was extremely insufficient.

30 (1948). Vazhneyshye reshenyya po sel'skomu khozyaystvu za 1938-1946 rr. [The most important decisions on agriculture for 1938-1946] Moskva: Sel'khozgyz. P. 390.

31 Verhunov, V. A. (red.). (2012). Sil's'ke hospodarstvo URSR ta yoho naukove zabezpechennya u 1940-1946 rokakh: zb. dok. i materialiv. [USSR agriculture and its scientific support in 1940-1946: coll. dock. and materials.] NAAN, DNS·HB, TSDAVO Ukrayiny. Kyyiv: Nilan-LTD. P. 19.

${ }^{32}$ Verhunov, V. A. (red.). (2012). Sil's'ke hospodarstvo URSR ta yoho naukove zabezpechennya u 1940-1946 rokakh: zb. dok. i materialiv. [USSR agriculture and its scientific support in 1940-1946: coll. dock. and materials.] NAAN, DNS·HB, TSDAVO Ukrayiny. Kyyiv: Nilan-LTD. P. 26. 
The researchers also focused on regional and district meetings on the effective agricultural production. They consulted collective and state farms on appropriate organization of the territory of management ${ }^{33}$. Moreover, they provided collective and state farms with varietal seeds, prepared specialists in agriculture, assisted in organization of field work ${ }^{34}$.

The researchers from scientific institutions systematically visited the rural areas, where they instructed foremen and section leaders, developed schemes of transitional crop rotations, organized work on the destruction of pests in the fields ${ }^{35}$. The implementation of the aforementioned measures ensured the successful implementation of spring sowing of agricultural crops in 1944. Collective farms of the Ukrainian SSR sowed 8 million hectares of arable land, and by the end of spring they fulfilled the plan of planting spring crops by $117 \%$, sugar beet - by $106 \%$, sunflower - by $119 \%$. Collective fams of Dnipropetrovsk region sowed more than 110.4 thousand hectares of spring crops, Kyiv region -84 thousand hectares, Kamenets-Podilskiy region - 30 thousand hectares. The development of pre-war acreage of crops was effectively carried out. In particular, in 1944 the total sown area of agricultural crops in the Ukrainian SSR reached $71 \%$ of the prewar size, grain crops $-80 \%$. In $1945,76 \%$ of the pre-war total acreage of agricultural crops was sown, $84 \%$ of grain crops, $125 \%$ of sunflower, $121 \%$ of millet.

The land management was a crucial component of the restoration process in agriculture. Particularly, the restoration and stocktaking of the land documentation, which was $97.2 \%$ destroyed in collective farms

33 (1944). Informatsiya RNK URSR i TSK KP(b)U pro zabezpechennya nasinnym materialom dlya posivu ovochiv ta tekhnichnykh kul'tur u $1944 \mathrm{r}$. [Information of the RNK of the USSR and the Central Committee of the Communist Party (b) U on the provision of seed material for sowing vegetables and industrial crops in 1944] TSDAVO Ukrayiny. F. 27. Op. 17. Spr. 43. Ark. 76.

34 Kalachykov, O. T. (1945). Dosyahnennya y zavdannya naukovo-doslidnykh zakladiv Narkomzemu Ukrayiny . [and tasks of the National Research Commissions of Ukraine.] Sil's 'ke hospodarstvo Ukrayiny. 1. P. 60.

35 (1946). Spravka o sostoyanyy roboty Ukraynskoho nauchno-yssledovatel'skoho ynstytuta zernovoho khozyaystva ym. V.V. Kuybysheva za 1946 h. [Information on the status of robots of the Ukrainian Grain Research Institute named by V. V. Kuibyshev for 1946] TSDAVO Ukrayiny. F. 27. Op. 17. Spr. 40. Ark. 359. 
during the occupation, was of great importance. Considerable attention was paid to the transfer of land documentation to the land users, bringing to the state-established standards of land usage of collective farms and farmers, as well as workers and employees who lived in rural areas, updating and implementing the correct organization of the territory in collective and state farms ${ }^{36}$.

The restoration of crop rotations in the collective farms of all liberated regions of the Ukrainian SSR was rapidly carried out. By the end of 1943, crop rotations had been restored in 10145 collective farms in the left-bank regions. At the beginning of 1944, their number was $15945^{37}$, at the beginning of 1945 it reached 26487 collective farms $^{38}$ and 705 state farms $^{39}$, although many of them did not have the necessary resource base, draught animals, qualified staff members and a sufficient number of workers ${ }^{40}$.

One of the most important tasks in the process of restoration of agriculture of the Ukrainian SSR was the restoration of pre-war acreage. First of all, cultivated areas of grain, vegetable crops, potatoes, sunflowers were restored, namely, those crops, the cultivation of which enabled to solve the food problem in the country. Despite the implementation of extensive agrotechnical measures, aimed at restoring

36 (1946). Postanovy Rady Ministriv URSR shchodo diyal'nosti naukovodoslidnykh ustanov u 1946 r. [Resolutions of the Council of Ministers of the USSR on the Activity of Research Institutions in 1946] TSDAVO Ukrayiny. F. R-2. Op. 7. Spr. 3353. Ark. 4, 16.

37 (1944). Materialy sesiyi Verkhovnoyi Rady URSR z pytannya «Cherhovi zadachi vidnovlennya sil's'koho hospodarstva URSR» u 1944 r. [Materials of the session of the Verkhovna Rada of the USSR on the issue "Regular tasks of restoration of agriculture of the USSR" in 1944] TSDAHO Ukrayiny. F. 1. Op. 30. Spr. 62. Ark. 130.

38 (1946). Materialy z vidrodzhennya naukovo-doslidnoyi roboty Myronivs'koyi derzhavnoyi selektsiynoyi stantsiyi za 1944-1946 rr. [Materials on the revival of the research work of the Mironov state breeding station for 1944-1946.] TSDAVO Ukrayiny. F. R-27. Op. 17. Spr. 5556. Ark. 21.

${ }^{39}$ (1945). Korotkyy dovidnyk sektora informatsiyi upravlinnya spravamy RNK URSR z osnovnykh pokaznykiv narodnoho hospodarstva URSR u 1945 r. [Brief reference book of the information sector of the RNA management of the USSR RNA on the main indicators of the Ukrainian economy of the USSR in 1945.] TSDAHO Ukrayiny. F. 1. Op. 23. Spr. 3987. Ark. 109.

${ }^{40}$ Vidomosti pro nayavnist' i stan traktoriv v URSR u 1942-1943 rr. [Information on the presence and condition of tractors in the USSR in 1942-1943.] TSDAVO Ukrayiny. F. R-27. Op. 18. Spr. 6. Ark. 16. 
the acreage during the period of reconstruction, its total territories comprised only 20,932 thousand hectares in 1944, in other words $69.2 \%$ of the pre-war area. The sown area of grain and leguminous crops was 15775 thousand hectares or $61.1 \%$, sunflower 852 thousand hectares or $120 \%$, potatoes -1738 thousand hectares or $85.9 \%$, vegetables - 417 thousand hectares or $87.4 \%$, sugar beet 287 thousand hectares or $31.6 \%{ }^{41}$.

The plan for the development of arable land in the Ukrainian SSR (1944) was carried out by collective farms at $104 \%$. State farms reclaimed 711 thousand hectares or $71 \%$ of the pre-war total acreage of crops. In 1945, the overall area of sowing increased by 1.9 million hectares in comparison with 1944. In 1945, in general, the Ukrainian SSR reclaimed $76 \%$ of the pre-war total sown area of crops. The sown area of grain reached $84 \%$ of the pre-war level, sunflower $-125 \%$, millet $-121 \%$. In 1945, owing to the achievements of scientific and research institutions, Ukrainian villages provided the state with more than 12 million tons of grain; almost 3 million tons of winter wheat and spring barley; 2.5 million tons of winter rye and 1.3 million tons of oats ${ }^{42}$.

The scientific and research institutions of animal husbandry improved breed and economic quality of cattle, types of pigs, coarse-woolen and metis sheep to meet the requirements of the resolution of the Central Committee of Communist Party and the Council of People's Commissars of the Ukrainian SSR № 572 "On the state development of animal husbandry in collective and state farms in the Ukrainian SSR in 1945", dated April 19, $1945^{43}$. Scientists carried out breeding work for sheep,

41 (1945). Korotkyy dovidnyk sektora informatsiyi upravlinnya spravamy RNK URSR z osnovnykh pokaznykiv narodnoho hospodarstva URSR u 1945 r. [Brief reference book of the information sector of the RNA management of the USSR RNA on the main indicators of the Ukrainian economy of the USSR in 1945.] TSDAHO Ukrayiny. F. 1. Op. 23. Spr. 3987. Ark. 49, 119.

${ }^{42}$ Perekhrest, O. H. (2011). Sil's'ke hospodarstvo Ukrayiny v 1943-1945 rr.: problemy ta rezul'taty vidbudovy. Ukrayina $v$ druhiy svitoviy viyni: pohlyad z XXI st.: istorychni narysy. [Agriculture of Ukraine in 1943-1945: Problems and results of reconstruction. Ukraine in the Second World War: A View from the 21st Century: Historical Essays] Kyyiv: Naukova dumka. P. 573.

${ }^{43}$ Verhunov, V. A. (red.). (2012). Sil's'ke hospodarstvo URSR ta yoho naukove zabezpechennya u 1940-1946 rokakh: zb. dok. i materialiv. [USSR agriculture and its scientific support in 1940-1946: coll. dock. and materials.] NAAN, DNS·HB, TSDAVO Ukrayiny. Kyyiv: Nilan-LTD. P. 26. 
rabbit and fish farming, established breeding resources of horses in the main regions of the Ukrainian SSR. The scientists identified the methods of accelerated apicultural breeding with high productivity of honey and wax, analyzed the maturity of honey on its physical properties. All these achievements played an important role for the development of animal husbandry in the Ukrainian SSR during the period of reconstruction.

In the early 1947, after the reconstruction of institutions, experimental stations and fields, the network of agricultural research institutions in the Ukrainian SSR consisted of 129 units in comparison with 165 research institutions in 1938. To them belonged 17 research institutes, 52 experimental stations, branches and laboratories, 60 scientific fields and experimental stations ${ }^{44}$. In the postwar period, scientists succeeded in the development of agricultural science, for instance: improving the culture of farming and assisting agricultural authorities, collective farms and state farms in the introduction of scientific achievements and best practices, developing of measures to increase crop and livestock productivity ${ }^{45}$.

In the period of reconstruction, scientists developed methods of soil fertilization to increase the sugar content of beets and rubber in Kok-sagizi with the assistance of the Department of Agricultural Sciences of the Academy of Sciences of the Ukrainian SSR. The system of potash feeding Kok-sagizu was recommended by scientists and provided an increase in the yield of this crop depending on the properties of the soil by $11-42 \%$, seed productivity of leached soils by $40 \%{ }^{46}$. Owing to the introduction of a new fertilizer system, the yield of

44 (1945). Zvit NKZS URSR pro vyrobnychu diyal'nist' i pro khid evakuatsiyi mayna MT·S, kolhospiv ta inshykh sil's'kohospodars'kykh orhanizatsiy NKZS URSR $\mathrm{u}$ period Velykoyi vitchyznyanoyi viyny 1941-1945 rr. [Report of the NKZS of the Ukrainian SSR on the production activity and the course of evacuation of property of MTS, collective farms and other agricultural organizations of the NKZS of the Ukrainian SSR during the Great Patriotic War of 1941-1945.] TSDAVO Ukrayiny. F. 27. Op. 17. Spr. 24. Ark. 17.

${ }^{45}$ Pshenychnyy, N. I. (1972). Do istoriyi rozvytku sil's'kohospodars'koyi nauky i doslidnoyi spravy na Ukrayini. [On the history of agricultural science and research in Ukraine.] Visnyk sil's 'kohospodars 'koyi nauky. 12. P. 42.

${ }^{46}$ Verhunov, V. A. (red.). (2012). Sil's'ke hospodarstvo URSR ta yoho naukove zabezpechennya u 1940-1946 rokakh: zb. dok. i materialiv. [USSR agriculture and its scientific support in 1940-1946: coll. dock. and materials.] NAAN, DNS·HB, TSDAVO Ukrayiny. Kyyiv: Nilan-LTD. P. 28. 
rubber per unit area, depending on the fertility and edaphic soil properties, increased by $31-71 \%$, and the content of rubber in the roots of Kok-sagizu - 1.7-2.0\%. Potash feed was also used in the cultivation of sugar beets, so that extremely high yields were received in the collective and state farms in the first year of their cultivation. Viral diseases of plants, physiology of sick plants and their immunity were under scrutiny, the factors leading to the decrease of clover seeds productivity were found out ${ }^{47}$. However, the search for effective measures to increase the productivity of crops and livestock was not extended by the Department of Agricultural Sciences of the Ukrainian SSR due to the imperfections of the organizational structure of the Academy of Sciences of the Ukrainian SSR. Along with the significant achievements of the Department of Agricultural Sciences of the Ukrainian SSR, some shortcomings can be pointed out: the lack of systematic connections with the departments of agricultural promotion and propaganda of the Ministry of Agriculture of the Ukrainian SSR on the problems of implementation of science achievements in production, lack of resource provision at pilot farms, the lack of specific industrial institutions in the Ukrainian SSR, etc.

\section{CONCLUSION}

Taking into consideration all mentioned above we can come to the following conclusion. During 1943-1945, the scientists of Ukrainian SSR scientific and research institutions solved significant problems of organizational and economic consolidation of research institutes, experimental stations and fields, and those concerning prospective development of agricultural experimental industry in the country. Scientists paid great attention to improving the assistance of collective and state farms of the Ukrainian SSR in eliminating the consequences of fascist invasive barbaric management. In the sphere of agriculture and crop production, the scientists of research institutions developed appropriate agro-technical measures for the further reconstruction of grain and beet farms, in particular, implemented scientifically substantiated grain and beet crop rotations as the basis of effective agriculture. Besides, effective soil treatment and application of organic

47 (1948). Vazhneyshye reshenyya po sel'skomu khozyaystvu za 1938-1946 rr. [The most important decisions on agriculture for 1938-1946] Moskva: Sel'khozgyz. P. 50. 
and mineral fertilizers were also in the focus of attention. A powerful forage base was created in collective farms for further reconstruction of animal husbandry. In this sphere, the scientists of scientific and research institutions aimed their work at the study of measures to improve meadows and pastures, the implementation of productive grass mixtures in field and fodder crop rotations in the production.

\section{SUMMARY}

The article states, that during the period of reconstruction (1943-1945), the state regulation of conducting agricultural scientific researche was managed by the following scientific and methodological centres: the People's Commissariat of agriculture of the Ukrainian SSR and the People's Commissariat of agriculture of food industry of Ukrainian SSR. From 1945, the problems of scientific support of agricultural production were also solved by scientists of the Department of Agricultural Sciences of the Academy of Sciences of the Ukrainian SSR.

It is pointed out that the coordination activity of the Sector of scientific and research institutions of the People's Commissariat of Agriculture of the Ukrainian SSR played a vital role in the development and production process of agriculture of the Ukrainian SSR. Wellknown scientific and research institutions that solved important problems to eliminate the consequences of barbaric management of the Nazi invaders, as well as organizational, economic and scientific development of research institutes, stations and fields that performed research in various fields subordinated to the People's Commissariat of Agriculture of the Ukrainian SSR. Significant amount of work of scientific and research institutions was done in the following areas: agriculture and crop production, selection and seed crops, agronomic melioration and mechanization of agriculture, fruit growing, viticulture and winemaking, as well as animal husbandry.

\section{REFERENCES}

1. Torzecki, R. (1994) Die Rolle der Zusammenarbeit mit der deutschen Be-satzungsmacht in der Ukraine für deren Okkupationspolitik [The role of cooperation with the German representative power in Ukraine for its occupation policy] Europa unterm Hakenkreuz. Okkupation und Kollaboration 1938-1945, 
Achtbändige Dokumentenedition. [Europe under the swastika. Occupation and collaboration 1938-1945, eight-volume document edition] Bd. 1, Berlin/Heidelberg, S. 239-273 (in German)

2. Torzecki, R. (1993). Polacy I Ukraincy. Sprawa ukrainska w czasie II wojny swiatowej na terenie II Rzeczypospolitej.[Poles and Ukrainians. The Ukrainian case during World War II in the territory of the Second Polish Republic] Warszawa: Wydawnictwo naukowe PWN. 349 s. (in Polish)

3. . (1948). Vazhneyshye reshenyya po sel'skomu khozyaystvu za 1938-1946 rr. [The most important decisions on agriculture for 1938-1946] Moskva: Sel'khozgyz. 460 s (in Russian)

4. Verhunov, V. A. (2012). Sil's 'kohospodars'ka doslidna sprava $v$ Ukrayini vid zarodzhennya do akademichnoho isnuvannya: orhanizatsiynyy aspekt. [Agricultural research in Ukraine from birth to academic existence: an organizational aspect.] Kyyiv: Ahrarna nauka. 416 s. (in Ukrainian)

5. Verhunov, V. A. (red.). (2012). Sil's 'ke hospodarstvo URSR ta yoho naukove zabezpechennya u 1940-1946 rokakh: zb. dok. $i$ materialiv. [USSR agriculture and its scientific support in 1940-1946: coll. dock. and materials.] NAAN, DNS·HB, TSDAVO Ukrayiny. Kyyiv: Nilan-LTD. 756 s. (in Ukrainian)

6. Verhunov, V. A. \& Khyzhnyak, V. P. (2004). Ukrayins'ki naukovo-doslidni sil's'kohospodars'ki zaklady $\mathrm{V}$ roky Velykoyi Vitchyznyanoyi viyny. [Ukrainian agricultural research institutions during the Great Patriotic War.] Istorychni zapysky: zbirnyk naukovykh prats'. 1. S. 19-25.

7. Vidomosti pro nayavnist' i stan traktoriv v URSR u 1942-1943 rr. [Information on the presence and condition of tractors in the USSR in 1942-1943.] TSDAVO Ukrayiny. F. R-27. Op. 18. Spr. 6. Ark. 16.

8. Vlasenko, S. (2010). Naslidky nimets'koyi okupatsiyi dlya sil's 'koho hospodarstva viys'kovoyi zony Ukrayiny (za dokumentamy derzhavnykh arkhiviv Ukrayiny). [Consequences of German occupation for agriculture of the military zone of Ukraine (according to documents of the state archives of Ukraine)] Kyyiv. 110 s. (in Ukrainian)

9. (1944). Dodatok do Nakazu № 1147 NKZS URSR pro vidnovlennya ta stan roboty naukovo-doslidnykh ustanov za 1944 r. [Addendum to the Order \# 1147 of the NKVD of the USSR on the 
restoration and state of operation of research institutions for 1944] TSDAVO Ukrayiny. F. 27. Op. 17. Spr. 1053. Ark. 292-293.

10. (1945). Dopovidni zapysky i dovidky pro rezul'taty perevirky spivrobitnykamy NKZS URSR stanu tvarynnytstva $\mathrm{v}$ kolhospakh URSR (za oblastyamy) u 1945 r. [Additional notes and certificates on the results of the examination of the stock-raising of the livestock in the collective farms of the Ukrainian SSR (by oblasts) in 1945] TSDAVO Ukrayiny. F. R-27. Op. 17. Spr. 8886. Ark. 6.

11. (1945). Dopovid' Narkoma zemlerobstva URSR H.P. Butenka na Pershomu respublikans'komu zasidanni peredovykiv produktyvnoho tvarynnytstva i konyarstva kolhospiv URSR vid 24-27 hrudnya 1945 r. [Report of the People's Commissar of Agriculture of the Ukrainian SSR GP Butenko at the First Republican Meeting of the Leaders of Productive Livestock and Horse Breeding of the Collective Farms of the USSR from December 24-27, 1945.] TSDAVO Ukrayiny. F. R-27. Op. 17. Spr. 8882. Ark. 7-8.

12. (1945). Zvit NKZS URSR pro vyrobnychu diyal'nist' i pro khid evakuatsiyi mayna MT.S, kolhospiv ta inshykh sil's'kohospodars'kykh orhanizatsiy NKZS URSR u period Velykoyi vitchyznyanoyi viyny 1941-1945 rr. [Report of the NKZS of the Ukrainian SSR on the production activity and the course of evacuation of property of MTS, collective farms and other agricultural organizations of the NKZS of the Ukrainian SSR during the Great Patriotic War of 1941-1945.] TSDAVO Ukrayiny. F. 27. Op. 17. Spr. 24. Ark. 4-58.

13. Zubets', M. V. (red.). (2008). Viddil sil's'kohospodars 'kykh nauk Natsional'noyi akademiyi nauk Ukrayiny (1945-1956): zb. dok. $i$ materialiv. [Department of Agricultural Sciences of the National Academy of Sciences of Ukraine (1945-1956): Coll. dock. and materials]. UAAN, DNS·HB UAAN, NAN Ukrayiny, NBU im. V. I. Vernads'koho. Kyyiv: Ahrarna nauka. 400 s.

14. (1944). Informatsiya RNK URSR i TSK KP(b)U pro zabezpechennya nasinnym materialom dlya posivu ovochiv ta tekhnichnykh kul'tur u 1944 r. [Information of the RNK of the USSR and the Central Committee of the Communist Party (b) U on the provision of seed material for sowing vegetables and industrial crops in 1944] TSDAVO Ukrayiny. F. 27. Op. 17. Spr. 43. Ark. 76. 
15. Kalachykov, O. T. (1945). Dosyahnennya y zavdannya naukovo-doslidnykh zakladiv Narkomzemu Ukrayiny .[and tasks of the National Research Commissions of Ukraine.] Sil's'ke hospodarstvo Ukrayiny. 1. S. 59-61.

16. (1945). Korotkyy dovidnyk sektora informatsiyi upravlinnya spravamy RNK URSR z osnovnykh pokaznykiv narodnoho hospodarstva URSR u $1945 \mathrm{r}$. [Brief reference book of the information sector of the RNA management of the USSR RNA on the main indicators of the Ukrainian economy of the USSR in 1945] TSDAHO Ukrayiny. F. 1. Op. 23. Spr. 3987. Ark. 48-129.

17. (1946). Materialy z vidrodzhennya naukovo-doslidnoyi roboty Myronivs'koyi derzhavnoyi selektsiynoyi stantsiyi za 1944-1946 rr. [Materials on the revival of the research work of the Mironov state breeding station for 1944-1946.] TSDAVO Ukrayiny. F. R-27. Op. 17. Spr. 5556. Ark. 21-22.

18. (1944). Materialy sesiyi Verkhovnoyi Rady URSR z pytannya "Cherhovi zadachi vidnovlennya sil's'koho hospodarstva URSR" u 1944 r. [Materials of the session of the Verkhovna Rada of the USSR on the issue "Regular tasks of restoration of agriculture of the USSR" in 1944] TSDAHO Ukrayiny. F. 1. Op. 30. Spr. 62. Ark. 109-246.

19. (1945). Merezha naukovo-doslidnykh ustanov NKZS URSR za 1945 r. [Network of Research Institutes of the NKVD of the USSR for 1945] TSDAVO Ukrayiny. F. 27. Op. 17. Spr. 1728. Ark. 144-146.

20. Ovsiyenko, A. M. (2010). Osoblyvosti finansovoyi systemy Ukrayins'koyi RSR u vidbudovchyy period (druha polovyna 40-kh pochatok 50-kh rokiv XX st.). [Features of the financial system of the Ukrainian SSR in the reconstruction period (the second half of the $1940 \mathrm{~s}$ - the beginning of the 1950s).] Kyyiv. 56 s. (in Ukrainian)

21. Perekhrest, O. H. (2011). Sil's'ke hospodarstvo Ukrayiny $v$ 1943-1945 rr.: problemy ta rezul'taty vidbudovy. Ukrayina $v$ druhiy svitoviy viyni: pohlyad $z$ XXI st.: istorychni narysy. [Agriculture of Ukraine in 1943-1945: Problems and results of reconstruction. Ukraine in the Second World War: A View from the 21st Century: Historical Essays] Kyyiv: Naukova dumka. S. 563-615. (in Ukrainian)

22. (1945). Postanovy RNK URSR i TSK KP(b)U shchodo diyal'nosti naukovo-doslidnykh ustanov u 1945 r. [Resolutions of the RNA of the USSR and the Central Committee of the Communist Party 
of Ukraine (b) U concerning the activities of research institutions in 1945] TSDAVO Ukrayiny. F. 27. Op. 17. Spr. 49. Ark. 128-139.

23. (1946). Postanovy Rady Ministriv URSR shchodo diyal'nosti naukovo-doslidnykh ustanov u 1946 r. [Resolutions of the Council of Ministers of the USSR on the Activity of Research Institutions in 1946] TSDAVO Ukrayiny. F. R-2. Op. 7. Spr. 3353. Ark. 4-16.

24. Pshenychnyy, N. I. (1972). Do istoriyi rozvytku sil's'kohospodars'koyi nauky i doslidnoyi spravy na Ukrayini. [On the history of agricultural science and research in Ukraine.] Visnyk sil's 'kohospodars'koyi nauky. 12. S. 38-46.

25. (1946). Spravka o sostoyanyy roboty Ukraynskoho nauchnoyssledovatel'skoho ynstytuta zernovoho khozyaystva ym. V.V. Kuybysheva za $1946 \mathrm{~h}$. [Information on the status of robots of the Ukrainian Grain Research Institute named by V.V. Kuibyshev for 1946] TSDAVO Ukrayiny. F. 27. Op. 17. Spr. 40. Ark. 247-406.

26. (1975). Ukraynskaya SSR v Velykoy Otechestvennoy voyne Sovetskoho Soyuza 1941-1945 rr. [The Ukrainian SSR in the Great Patriotic War of the Soviet Union 1941-1945.] V 3-kh t. T. 3. Kyev: Polytyzdat. 565 s. (in Russian)

\section{Information about the author: Olena Korzun,}

Candidate of Historical Sciences, Doctoral student of the National Scientific Agricultural Library of National Academy of Agrarian Sciences of Ukraine, 10, Geroiv Oborony str., Kyiv, 03127, Ukraine ORCID ID: orcid.org/0000-0003-2869-9549 


\section{ESTABLISHMENT AND DEVELOPMENT OF SCIENTIFIC FOUNDATIONS OF THE SANITARY AND HYGIENIC SCIENCE IN UKRAINE (SECOND HALF OF THE 19 ${ }^{\mathrm{TH}}$ BEGINNING OF THE $20^{\text {TH }}$ CENTURIES)}

\section{Nadiya Kotsur}

\section{INTRODUCTION}

Hygienic science has passed a difficult path of formation and development, relying on the best traditions, experience, and achievements of theoretical and clinical medicine, consistently developing a preventive direction in domestic medicine. Many prominent hygienists have been educated on the best traditions, leading-edge views of count doctors, who have developed and implemented the social and hygiene principles of public health.

Today, more than ever, the scientific thought proclaimed at the beginning of the twentieth century by Professor S. A. Tomilin remains relevant, stating that "... prevention is a social discipline and the prevention of infectious diseases refers to measures of general health, that is, measures aimed at raising the level of social immunity to acute infections". In this regard, it is important to focus on the experience of the past on the current problem of diagnosis and prevention of infectious diseases. The epidemic situation in recent years regarding such infectious diseases as tuberculosis, measles, and diphtheria has been complicated. As with the dawn of the emergence of hygiene science, conditions must be created to make information about preventative care available to the general public. In the framework of the implementation of prevention programs must also take part in the power structures, because improving the environment as a whole is the basis of prevention of infectious diseases.

1 Tomilin S. A. (1931). Sotsial'no-meditsinskaya profilaktika : teoreticheskoe obosnovanie $i$ prakticheskaya postanovka [Social-medical prophylaxis : theoretical ground and practical raising]. Khar'kov : Gosmedizdat, USSR, pp. 32-33. (in Ukrainian) 
At the same time, the transfer of historical experience from generation to generation, which determines the progress of hygiene science, helps to creatively solve urgent problems of hygiene in order to create favorable and safe conditions of human life, improve the health of the population. That is why there is a need to turn to the history of the development of hygiene as a science and practical field of medicine, to use the techniques and some methodological approaches of scientific discoveries of the past in a new round of socio-economic development in connection with the emergence of new diseases of the $21^{\text {st }}$ century.

In modern historiography, there is a considerable amount of scientific work devoted to certain aspects of the formation and development of hygiene in Ukraine, eg. Bazhan T. A., Paranko N. M., Karnaukha N. H. ${ }^{2}$, Hrynzovkyi A. M. ${ }^{3}$, Kotsyr N. I. ${ }^{4}$ and others. At the same time, there is an acute shortage of works that reflect the characteristic features and ways of developing hygienic knowledge and sanitary practices and the background of social, economic and political challenges of the second half of the 19th - early 20th centuries.

In this connection, the purpose of this work is to highlight the prerequisites for the emergence, features of the formation and development of scientific foundations of sanitary and hygiene in the territory of Ukraine in the second half of the nineteenth - early twentieth century based on the application of general scientific principles of historical search (historicism, objectivity, systematicity, continuity, complexity, etc.) and systems of complementary methods (interdisciplinary and historical).

${ }^{2}$ Bazhan T. A., Paran'ko N. M., Karnaukh N. (2005). O gigiene $i$ gigienistakh [About a hygiene and hygienists]. Dnepropetrovsk : Zhurfond. (in Ukrainian)

3 Ghrynzovsjkyj A. M. (2005). Systemnyj analiz stanovlennja i formuvannja medyko-profilaktychnogho fakuljtetu ta ghighijenichnoji nauky Nacionaljnogho medychnogho universytetu imeni O.O. Boghomoljcja [System analysis of formation and formation of the Faculty of Medicine and Prevention and Hygiene Science of the OO National Medical University The worshiper] (PhD Thesis), Kyiv: Kyjivsjkyj nacionaljnyj medychnyj universytet imeni O. O. Boghomoljcja. (in Ukrainian)

${ }^{4}$ Kocur N. I. (2011). Stanovlennja i rozvytok ghighijenichnoji nauky v Ukrajini: shljakh krizj epokhy i socialjni potrjasinnja (drugha polovyna XIX - 20-i rr. XX stolittja [Formation and development of hygienic science in Ukraine: a way through epochs and social upheavals (second half of XIX - 20th years of XX century: monograph]. Korsunj-Shevchenkivsjkyj. (in Ukrainian) 


\section{Prerequisites for the formation of scientific foundations in sanitary and hygiene matter}

In the development of hygienic thought, the formation of the scientific foundations of sanitary and hygiene business in the second half of the $19^{\text {th }}$ century in Ukraine played a major role in the rapid development of the economy, the growth of production, which set new, increasingly complex tasks for science and society. The reform of the abolition of serfdom in 1861 contributed to the delamination of the countryside and the rapid development of capitalism. At that time, the number of industrial workers was growing rapidly. At the same time, harsh working and living conditions, working days of 12-15 hours a day in factories, the widespread use of women's and children's labor, poor living conditions where many workers lived in dugouts and barracks, lack of occupational safety contributed to high morbidity and injury. At some plants (for example, in Katerynoslav, Dniprodzerzhynsk), the incidence was 1626 per 1,000 workers, of which $34 \%$ were infectious. Injuries were very high, in particular, out of 1,000 cases a year, 750 had boilermakers ${ }^{5}$.

Poor working and living conditions have contributed to the spread of cholera, smallpox, and typhoid epidemics. The demands of the workers, their protests about the improvement of working and living conditions increased. It was at this time that various societies began to emerge, discussing these problems, giving recommendations on the elimination of sources of various epidemics. An important role in this played the Russian Society for Public Health (1878), which had 27 offices in different cities, published scientific and popular hygiene magazines ${ }^{6}$.

The Society for the Protection of Cities also dealt with the issues of water supply to cities, improvement of living conditions, food, and

\footnotetext{
${ }^{5}$ Ighumnov S. M. (1957). Narys rozvytku zemsjkoji medycyny na Ukrajini [Essay on the development of Zemsky medicine in Ukraine]. Materialy do istoriji rozvytku okhorony zdorov'ja na Ukrajini [Materials on the history of health care development in Ukraine] / Pid red. K. F. Duplenka. Kyiv: Derzhavne medychne vydavnyctvo URSO, pp. 124-168. (in Ukrainian)

${ }^{6}$ Zabludovskiy P. E. (1970). Puti razvitiya obshchestvennoy meditsiny [Ways of development of public medicine]. Moskva, pp. 71-73. (in Russian)
} 
demanded the organization of laboratories for quality control of products. The health statistics were gradually accumulating, which contributed to the dissemination of health information.

The development of domestic medical science in the second half of the nineteenth century was closely linked to the socio-economic and political situation of Russia. The reforms of the 1960s, including in the health sector, played a positive role in contributing to the rapid economic development of the country. In the field of health care, the county's reform promoted the emergence and rapid development of a special form of public medicine, the so-called counties, which later became a model for urban and factory medicine. During this period, more favorable conditions for medical training and scientific activities were created.

On the basis of great achievements in the field of chemistry, physics and other fields of science, the preconditions for the development of experimental hygiene are created. It was in the second half of the nineteenth century that the work of eminent hygienists, who laid the foundations of national scientific hygiene, for the development of which was based on the achievements of natural science, took place in the Russian Empire.

From the first years of the organization of county medicine after the county reform of 1861, it became clear that medical treatment alone could not ensure the health of the population and the fight against epidemics.

A major event in the history of count medicine is the congress of provincial conventions of county doctors in the early 1970s. They were initiated by Tver county (1871), followed by other counties. In Ukraine - Kherson county (1874). In the early ' 80 s of the 19th century, congresses were held in all 34 provinces. In 35 years the largest number of congresses took place in Moscow and Kherson provinces - 16 each. $^{7}$ Topical issues of public medicine, including the issue of establishing a health organization, were raised at the congresses. But the sanitary business was implemented with great difficulty as its tasks relied on

${ }^{7}$ Kagan S. S. (1965). K stoletiyu zemskoy meditsiny na Ukraine [To the century of zemskoy medicine on Ukraine]. Ocherki istorii russkoy obshchestvennoy mediny (K stoletiyu zemskoy meditsiny) [Essays of history of Russian public mediny (To the century of zemskoy medicine)]. M.: Meditsina, pp. 85-86 (in Russian) 
county medicine. Only in the course of development of medical establishments and improvement of medical business, there was a problem of training of hygienists, meaning district sanitary doctors.

The development of hygienic thought and sanitation in Ukraine was greatly influenced by the activities of the County Sanitary Organization, which dealt with statistics, the study of morbidity, physical development, and population migration.

In the 60 s of the $19^{\text {th }}$ century in Ukraine, the initiator of many sanitary measures was Poltava county, which in 1867 organized a permanent commission of social and hygienic orientation.

Among the prominent county sanitary doctors, organizers of sanitary affairs in Ukraine, an important role was played by M. I. Tiaziakov, O. V. Korchak-Chepurkivskyi (Kherson province), A. L. Smidovych (Katerynoslav province), M. I. Igumnov (Kharkiv province). Under their leadership, the sanitation organization has achieved considerable success. At the same time, the count doctors were the most progressive health doctors because they had to conflict with the authorities in order to improve the health status of the population $^{8}$.

The main role in the dissemination of hygiene knowledge among the population in the early ' 80 s of the $19^{\text {th }}$ century played congresses and commissions at the Pyrogov Society. This commission from Ukraine included M. S. Uvarov - one of the leading theorists of count medicine organization - a tireless advocate of public medicine, who fought for the introduction of teaching public medicine - social hygiene and its inclusion in the curricula of higher medical school ${ }^{9}$.

For the dissemination of hygienic knowledge among the population, the society used various methods: hygienic education at school, publication, and distribution of popular literature, equipment of museums and mobile exhibitions, organization of lectures, readings, and conversations.

${ }^{8}$ Kagan S. S. (1965). K stoletiyu zemskoy meditsiny na Ukraine [To the century of zemskoy medicine on Ukraine]. Ocherki istorii russkoy obshchestvennoy mediny (K stoletiyu zemskoy meditsiny) [Essays of history of Russian public mediny (To the century of zemskoy medicine)]. M.: Meditsina, pp. 88-89. (in Russian)

${ }^{9}$ Zabludovsjkyj Yu. P. (1991). Istorija medycyny [History of medicine]. Kyiv, pp. 329-330. (in Ukrainian) 
M. S. Uvarov took an active part in the formulation and development of questions of medical statistics already at the $1^{\text {st }}$ Pyrogov Congress of Physicians and essentially remained a recognized authority in these matters at all subsequent stages of the development of Russian public medicine.

The successor of sanitary and hygienic ideas of M. S. Uvarov was O. V. Korchak-Chepurkivskyi, who passed from county sanitary doctor of Kherson province to the academician of UAS. Working as a sanitary doctor, O. V. Korchak-Chepurkivskyi studies peculiarities of the development of diphtheria among the rural population based on the study of epidemics in the Kherson county from 1870 to 1889 . The result of these studies was a monograph by O. V. KorchakChepurkiovskyi "Materials for the study of the epidemic of diphtheria (epidemiology) in Russia" (1898), which he successfully defended at Kyiv University and received a doctorate in medicine ${ }^{10}$.

Thus, in 1886, a sanitary organization was formed in the Kherson region, which, along with Moscow, was considered the foremost in the Russian Empire. In their model, sanitary organizations were created in other provinces. The fight against epidemics was one of the main tasks of county doctors. Advanced county doctors in Ukraine M. S. Uvarov, S. M. Igumnov, O. V. Korchak-Chepurkivskyi, M. I. Teziakov, and others became the initiators in the fight against epidemics.

Dissemination of hygiene knowledge among the population in all zemstvos was among the main tasks. In this work counties used mainly editions of the Pyrogov Society. Particularly widespread this work was in Kharkiv and Katerynoslav provinces. There were popular readings and conversations, popular postcards, etc. were distributed. Conducting such readings and conversations before 1906 was fraught with great difficulty. You could read only the brochures that had been published in advance, apart from general censorship, and also the special ones. These brochures had the right of the person who had obtained the

${ }^{10}$ Ighumnov S. M. (1957). Narys rozvytku zemsjkoji medycyny na Ukrajini [Essay on the development of Zemsky medicine in Ukraine]. Materialy do istoriji rozvytku okhorony zdorov'ja na Ukrajini [Materials on the history of health care development in Ukraine] / Pid red. K. F. Duplenka. Kyiv: Derzhavne medychne vydavnyctvo URSO, pp. 124-126. (in Ukrainian) 
permission of the governor, under the control and responsibility of a special supervisor appointed by the director of public schools in a predetermined room. In the following years, special lectures stood out and mobile exhibitions were created.

Thus, the formation and development of sanitary affairs during the Count Reform in Ukraine (1864-1917) took place in the difficult sanitary conditions of the tsarist regime and with great difficulty. But despite this, advanced county doctors, hygienists have made a significant contribution to the design and implementation of sanitary and anti-epidemic measures, public health education, control and prevention of infectious diseases.

\section{Formation and development of hygiene science in universities}

Great importance in the development of hygiene ideas and knowledge in Ukraine had the opening in the $19^{\text {th }}$ century of three universities: Kharkiv (1805), Kyiv (1834) with the medical faculty (1841) and Novorossiysk in Odesa (1865) with the medical faculty $(1900)^{11}$.

In the development of university medical education, in the training of doctors in Ukraine a huge role belonged to the outstanding scientist, brilliant surgeon, teacher, and public figure M. I. Pyrogov. His scientific views and ideas were of great importance, especially during the period of his activity as guardian of the Odesa and Kyiv educational districts.

The opening of Kyiv University was of great importance for the development of medical science, culture, education. M. I. Pyrogov paid much attention to the activities of the Faculty of Medicine at Kyiv University: attended lectures, classes, promoted the implementation of preventive ideas, because he believed that the future belongs to preventive medicine.

There were no separate departments of hygiene during this period, but some of its sections were studied in the course of other disciplines (food hygiene was studied simultaneously with dietetics, the issue of combating the incidence of medical police). Increased interest in

${ }^{11}$ Kryshtopa B. P. (1985). Vysshee meditsinskoe obrazovanie v Ukrainskoy SSR [Higher medical education is in Ukrainian SSR]. Kyiv, pp. 51-52. (in Ukrainian) 
occupational pathology and hygiene in connection with the development of industry, increasing the number of workers. An important role in this regard was played by the medical community.

From the second half of the $19^{\text {th }}$ century, hygiene began to be regarded as a science, which should develop the basics of sanitary surveillance, which further contributed to its establishment as an important medical discipline.

The difficult economic and political situation, famine, epidemics, low cultural level contributed to the spread of morbidity and mortality. All this pushed the leading medical community to search for effective measures aimed at reducing the morbidity and mortality of the population, the urgent need to expand sanitary and anti-epidemic measures, dictated the expediency of the development of hygiene science.

The desire of the leading professors of the Faculty of Medicine of Kyiv University to solve urgent problems of medicine, was reflected in the speech of one of the students and followers of M. I. Pyrogov, Professor of Anatomy O. P. Walter (30.08.1886) on the theme: "On the Importance of Medicine for Russia", in which he stated that it was not clinical medicine but public hygiene that should play a leading role in the public health system, and its development and wide practical application was one of the important tasks of state power. O. P. Walter suggested a number of specific measures aimed at raising hygiene to a level that would help to achieve its goals. Among the first, he calls the improvement of teaching hygiene in universities and teaching it in close connection with physiology, raises the question of the need for the organization of independent departments and points to the expediency of the division of the medical faculty into two departments - clinical and hygienic. Noting the state of hygiene teaching at Russian universities, O. P. Walter noted that public hygiene is taught only at the St. Volodymyr University in Kyiv ${ }^{12}$.

12 Barannik P. I., Benyumov R. Ya., Makarenko I. M. (1962). V. A. Subbotinorganizator i rukovoditel' pervoy kafedry gigieny na Ukraine [V. A. Subbotin is an organizer and leader of the first department of hygiene on Ukraine] Materialy $k$ istorii gigieny $i$ sanitarii na Ukraine [Materialy to istorii gigieny I sanitarii na Ukraine] / pod red. D. N. Kalyuzhnogo, A. A. Grando. Kyiv, pp. 264-277. (in Ukrainian) 
In the 50s of the $19^{\text {th }}$ century at Kyiv St. Volodymyr University has already been taught many aspects of hygiene knowledge, but the main methods of research were mainly descriptive - demographic and epidemiographic.

In the 60 s of the $19^{\text {th }}$ century due to the rapid development of the economy, high concentration of population in cities, deteriorating sanitation, epidemics hygienic issues are becoming relevant among many scientists. Of particular importance was the widespread adoption of experimental methods in scientific research. The Kyiv Society of Physicians also attached great importance to this, at which the issue of the importance of teaching hygiene in educational institutions was heard (L. A. Marovskyi, 1864). And although the creation of the Department of Hygiene at Kyiv St. Volodymyr University had been planned since 1865 and began to function only in 1871. Its founder was a talented scientist, hygienist V. A. Subotin ${ }^{13}$.

Based on the achievements of various branches of science, medicine of the second half of the nineteenth century has moved to the scientificexperimental method of cognition. Numerous experimental studies have proven the need for and relevance of teaching students new principles and methods of preventive measures to effectively combat the causes of diseases. With the formation of hygiene, as an independent branch of medicine, immediately the question of training specialists in the preventive direction of domestic medicine immediately raises.

One of the first was recognized by the German School of Hygienists, where Max Pettenkofer (1818-1901) rallied around like-minded people and organized the most powerful hygienic institution of the time, which first worked as a department of hygiene, and then as the Hygienic Institute in the Munich University ${ }^{14}$. Today it is one of the leading scientific institutions in Germany, called the Institute of Microbiology and Hygiene named after Max von Pettenkofer of the Munich University.

${ }^{13}$ Kocur N. I. (2011). Stanovlennja i rozvytok ghighijenichnoji nauky v Ukrajini: shljakh krizj epokhy i socialjni potrjasinnja (drugha polovyna XIX-20-i rr. XX stolittja [Formation and development of hygienic science in Ukraine: a way through epochs and social upheavals (second half of XIX - 20th years of XX century: monograph]. Korsunj-Shevchenkivsjkyj, pp. 407-408. (in Ukrainian)

${ }^{14}$ Bazanov V. A. (2009). Maks Pettenkofer i russkie gigienisty [Max Pettenkofer and Russian hygienisty]. Gigiena i sanitariya. № 5. pp. 41-44. (in Russian) 
The first generation of Russian hygienists has been trained at the University of Munich under the direction of M. Pettenkofer. It should be noted that the first student from the territory of Ukraine was a graduate from the St. Volodymyr University in Kyiv, Doctor of Medicine V. A. Subotin.

During his stay abroad, along with his scientific work, V. A. Subotin thoroughly studied the method of teaching hygiene at Western European universities, in particular in Munich, where M. Pettenkofer taught hygiene. He also purposefully studied the formulation of teaching hygiene in Paris, where he also gave lectures by the famous French chemist Wurts. He also attended the relevant course in Berlin. The range of scientific issues that V. A. Subotin has worked extensively abroad in the laboratories of various Western European scientists, and has been extremely diverse. They touched upon the problems of physiology and pathology, general issues of hygiene, food hygiene, communal hygiene, military hygiene, sanitary statistics, organization of sanitary affairs, and epidemiology.

Thus, in assuming the duties of Head of the Department of Hygiene, V. A. Subotin had a broad scientific outlook both in the field of hygiene and in other areas of theoretical and clinical medicine.

Like most domestic hygienists, Professor V. A. Subotin was not limited to an academic audience. In trying to give the hygienic aspects of the work a public character, he closely associates it with hygienic laboratories and a practical sanitation organization. An important point in improving the educational process was the more active involvement of students in scientific work. Special rules were issued at Kyiv University and subsequently spread to other universities in the Russian Empire, which defined the forms of student participation in scientific work. They consisted of conducting research under the guidance of professors in the clinics and laboratories in the university.

Professor V. A. Subotin constantly sought to increase the hours of study in the course of hygiene, the introduction of compulsory practical classes, equipment of the laboratory, the allocation of funds for the purchase of visual aids, the increase of educational facilities, etc. Thanks to V. A. Subotin's persistence was made some progress in the development of this department already at the stage of its formation. Topical issues of development of the department of hygiene were reflected in V.A. Subotin's note "On expanding the teaching of 
hygiene in Russian universities", which was presented to the Faculty of Medicine and published in the journal "Health". "Public hygiene," V. A. Subotin wrote, "has taken more than a secondary place in higher medical education for a very long time. The same secondary place of hygiene was occupied in the field of public health" 15 .

In the first years of the pedagogical activity, V. A. Subotin and other leading hygienists of the country had the task of great educational and methodological weight - to create original manuals and textbooks for domestic medical faculties. Simultaneously with the textbooks of such prominent Russian hygienists, such as F. F. Erisman and A. P. Dobroslavin, V. A. Subotin in 1882 published his "Short Course in Hygiene" $"$.

Analyzing the content of this textbook, we should note the scientific substantiation of V. A. Subotin the subject, goals, and tasks of hygiene. While denying the views of some of his predecessors that hygiene does not exist as an independent science, he notes that "thanks to the works of famous scientists - European hygienists - Petenkofer, Parkes, Levi, Merkel, J. Simon, and others., was a scientific path to this young, but not yet well-developed, field of knowledge that pursued its mission. It is hygiene designed to develop the area of knowledge that has the most powerful impact on physical well-being and human development. Since physiology, pathology, and statistics have taken a proper place in the study of hygiene, it has begun to acquire scientific foundations" $"$.

For the first time in his "Short Course in Hygiene", V. A. Subotin shows the relationship of hygiene with other sciences. In particular, he notes that hygiene uses knowledge from every field of science.

15 Subbotin V. A. (1882). O rasshirenii prepodavaniya gigieny $\mathrm{v}$ russkikh universitetakhn [About expansion of teaching of hygiene in Russians of universitetakh]. Zdorov'e. № 10 (178) (okt.). pp. 231-254. (in Ukrainian)

${ }^{16}$ Subbotin V. A. (1882). Kratkiy kurs gigieny profesora universitetu sv. Vladimira (sostavlen pri sodeystvii studentov 5-go kursa meditsinskogo fakul'teta) [Short-story course of hygiene to the profesora university sv. Vladimira (made at an assistance the students of 5th course of medical faculty)]. Kyiv : Tip. K. N. Milevskago. (in Ukrainian)

17 Orlov V. D. (1899). Viktor Andreevich Subbotin, kak uchenyy i professor [Victor Andrey Subbotin, as scientist and professor]. Universitetskie izv. № 2, pp. 246-259. (in Ukrainian) 
Accordingly, the entire body of knowledge is used by hygiene to address issues affecting human life and health. At the same time, natural sciences (physiology, physics, chemistry, medical geography, meteorology) play a paramount role, since they contribute most to the correct understanding of the conditions affecting human health. In addition to the natural sciences, when addressing certain social issues, hygiene refers to social sciences such as statistics, history, political economy, which help it to draw conclusions about the health of society as a unit. It should be noted that the most important role in the development of public hygiene V. A. Subotin assigns a statistical method of research. "Without it, writes V. A. Subotin, - hygiene would never go beyond private dietetics and sanitary police would never rise to the level of public hygiene in the broad sense of the word" ".

Continuation of "Short Course of Hygiene" was issued by V. A. Subotin in 1883 "Notes on Hygiene. Issue 1.", which outlined methods of practical study of air hygiene 19 . "Notes" also include a section on soil hygiene. In the same year, the "Hygiene Notes" were published lithographically, covering the issues of water hygiene and water supply. In 1884, two more issues of the "Notes on Hygiene" were published, covering other sections of the course on hygiene.

Therefore, the decisive role in the formation of the scientific foundations of hygiene in the second half of the nineteenth century had significant advances in the field of natural sciences (physics, chemistry, biology, physiology, microbiology). This contributed to the transition of hygiene from descriptive to experimental and its formation as an independent scientific field.

Faculty of Medicine, Kyiv st Volodymyr University, wherein 1865 was created one of the first in the Russian Empire independent departments of hygiene, belonged to a special role in the development of domestic hygiene science thanks to the prominent scientistshygienists, in particular, V. A. Subotin. It was he who founded the

${ }^{18}$ Subbotin V. A. (1882). Kratkiy kurs gigieny profesora universitetu sv. Vladimira (sostavlen pri sodeystvii studentov 5-go kursa meditsinskogo fakul'teta) [Short-story course of hygiene to the profesora university sv. Vladimira (made at an assistance the students of 5th course of medical faculty)]. Kyiv : Tip. K. N. Milevskago, pp. 269-270. (in Ukrainian)

19 Subbotin V. A. (1883). Zapiski po gigiene [Messages on a hygiene]. Vyp. 1. Kyiv. (in Ukrainian) 
Department of Hygiene at Kyiv St Volodymyr University, whereas a student and a follower of the prominent German scientist-hygienist, founder of scientific hygiene $M$. Pettenkofer, at a new scientifictheoretical and methodical level he created the concept of sanitaryhygienic education in universities of the Russian Empire.

Ideas of deepening and differentiation of teaching of hygienic science at Kyiv St Volodymyr University were embodied by the followers of Professor V. A. Subotin.

Professor V. D. Orlov, who headed the department in 1893-1914, succeeded in significantly improving the method of teaching hygiene. In 1894, his request to expand the teaching of hygiene was met, and he introduced practical hygiene training as a mandatory component of the educational process. From next year, he organizes field trips to get acquainted with the activities of the main sanitary institutions of the city. In 1905, Professor V. D. Orlov publishes "A Guide to Practical Occupational Hygiene and Medical Policing," which introduces students to basic methods of hygiene research and is used as one of the basic textbooks. During the teaching of hygiene in practical classes, each trainee had to master all the techniques that were known at that time. "At the same time, it is necessary that the method is simple, accessible and facilitated to obtain the expected results," - said V.D. Orlov in the manual ${ }^{20}$. In the section "General methods of sanitary researches" Professor V. D. Orlov points out the necessity of applying simpler methods by choosing scientifically proven methods and involving a large number of objects in the sanitary examination with the use of some methods of research.

Thus, Professor V.D. Orlov had great credit for developing practical hygiene classes and introducing them into the educational process.

Scientific advances in hygiene in the early $20^{\text {th }}$ century and their practical implementation formed the basis for the writing by Professor V. D. Orlov of a series of brochures "An overview of the successes of

20 Orlov V. D. (1905) Posobie $k$ prakticheskim zanyatiyam po gigiene $i$ meditsinskoy politsii dlya studentov meditsinskogo fakul'teta Imperatorskogo Universiteta sv. Vladimira [Manual to practical employments on a hygiene and medical police for the students of medical faculty of Emperor's University sv. Vladimira]. Kyiv:Tipografiya Imeratorskogo U-ta sv.Vladimira, pp. 25-26. (in Ukrainian) 
hygiene" $(1902,1903,1904,1905,1907,1908)$. The brochures analyze the publications of both domestic and foreign scientists in the field of hygiene.

In 1903, a private-associate course in epidemiology and sanitary statistics was organized at the base of the department for students of 4 and 5 courses. The emergence of the training course was due, first of all, to a high level of infectious disease, epidemics that periodically appeared in the late $19^{\text {th }}$ - early $20^{\text {th }}$ centuries. All this led to the need for the scientific development of epidemiology and teaching students the basics of infectious diseases.

In 1903, V. D. Orlov invited O. V. Korchak-Chepurkivskyi known for his socio-medical and statistical studies of the epidemiologist and hygienist to read courses in epidemiology and medical statistics. Thus, during this period the Department of Hygiene consisted of a professor, Dr. V. D. Orlov, who taught hygiene, medical and veterinary police and teaching about epizootic diseases, as well as a private docent, Doctor of Medicine O. V. Korchak-Chepurkivskyi, who read the newly introduced courses ${ }^{21}$.

A prominent role in the development of hygiene science belongs to the first in the territory of Ukraine Kharkiv University. With the opening of the Faculty of Medicine, the process of forming the departments of both medical and preventive care began.

In the development of hygiene science of the 19th - beginning of the 20th centuries, two historical periods should be distinguished at Kharkiv University: the first is the teaching of hygiene by specialists of different branches of medicine at the combined departments (1806-1871); the second since 1872 was the creation of an independent department of hygiene and the formation of its scientific foundations by hygienists.

The formation of domestic hygiene science in the second half of the nineteenth century is associated with the names of such prominent scientists, professors of Kharkiv University as A. I. Yakobii

${ }^{21}$ Kocur N. I. (2011). Stanovlennja i rozvytok ghighijenichnoji nauky v Ukrajini: shljakh krizj epokhy $i$ socialjni potrjasinnja (drugha polovyna XIX - 20-i rr. XX stolittja [Formation and development of hygienic science in Ukraine: a way through epochs and social upheavals (second half of XIX - 20th years of XX century: monograph]. Korsunj-Shevchenkivsjkyj, pp. 447-448. (in Ukrainian) 
(1837-1907) and I. P. Skvortsov (1847-1921). By learning about the scientific outlook of these scientists and the level of science at the time, one can better understand and evaluate their theoretical concepts and practical activities.

It should be noted that the creation of public hygiene was one of the important stages in the development of hygiene science of this period. Hygienists have regarded human beings in an integral part of society, in close connection with the factors that affect them in the context of social development. A. I. Yakobii and I. P. Skvortsov belong to a cohort of scientists - hygienists of the second half of the nineteenth century, who understood the importance of the social factor and developed hygiene as a social science. In their scientific works and lectures, scientists have propagated this idea.

The hygiene course taught by A. I. Yakobii at Kharkiv University contained many sections. His lectures, published in 1885 , have been preserved. The course of lectures is written by hand and reproduced in a limited number in a lithographic manner. This unique textbook has been preserved at Kharkiv Library named after V. G. Korolenko and is of exceptional scientific interest. The manual is published by the lecturer A. I. Yakobii under the title "Course of public hygiene",22.

Professor A. I. Yakobii manual "The course of public hygiene" covered the development of hygiene science and its implementation in practice in the second half of the nineteenth century. Professor I. P. Skvortsov improved the technique of teaching hygiene at the department and strengthened the experimental component of scientific work. His fundamental work, "Fundamentals of Hygiene and Hygiene," first covered the doctrine of the essence of life as a unity of man and environment, which played a decisive role in the development of hygiene science in the early twentieth century.

The followers and students of Professor I. P. Skvortsov in the 20's of the $20^{\text {th }}$ century - Ya. M. Zilber, A.A. Tsvetaiev, V.O. Uglov expanded the scope and content of hygiene knowledge, laid the foundations for differentiation of hygiene into different branches social hygiene, communal hygiene, occupational hygiene, nutrition

22 Yakobiy A. I. (1885). Kurs obshchestvenoy gigieny (napisano vid ruki, rozmnozheno litografichnim sposobom) [Course of obschestvenoy hygiene (otd hands are written, rozmnozheno by a lithographic method)]. Khar'kov. (in Ukrainian) 
hygiene and determined the direction of further research on topical issues of hygiene science and practice.

Therefore, a significant contribution to the development of domestic hygiene, the establishment and development of the first hygienic departments of the second half of the nineteenth century made by the hygienists of Kharkiv University - A. I. Yakobii and I. P. Skvortsov. They should be considered the founders of Ukrainian hygiene science, which by that time became experimental hygiene, and its foundation - the development of natural sciences.

The formation of the scientific foundations of hygiene and sanitation at Novorossiysk University was closely linked to the creation in 1903 of the Department of Hygiene at the Faculty of Medicine under the direction of Professor H. V. Khlopin.

In his scientific and pedagogical activity, H. V. Khlopin developed the ideas of the outstanding hygienists F.F. Erisman and A. P. Dobroslavin. According to the scientist, preventive medicine and public hygiene, the central object of which is a human being, should play a significant role in the development of health care.

The development of hygiene science H. V. Khlopin considered in close connection and mutual influence of research work and practice, their subordination to the tasks of health care. The scientist was convinced that the research should combine experimental analysis and rigorous scientific verification of all the facts that would form the basis for practical activities and the emergence of new scientific concepts.

Particularly noteworthy is the position put forward by H. V. Khlopin on the interrelation of phenomena and the need for the hygienist to study both the person and the conditions that surround him. Accordingly, under external conditions, he understood not only the surrounding nature but also the cultural environment and the social environment. "To exclude a social factor is to take the soul out of hygiene," H. V. Khlopin emphasized ${ }^{23}$.

Most of the provisions in H. V. Khlopin's scientific works are widely used in modern hygiene and medicine in general.

The hygienist, according to Professor H. V. Khlopin, must have mastered the statistical, physicochemical and physiological methods of

${ }^{23}$ Khlopin G. V. (1921). Osnovy gigieny [Bases of hygiene]. Moskva, pp. 94-95. (in Russian) 
research necessary for solving scientific and practical problems. At the same time, he pointed to the complex nature of sanitary and hygienic research. This provision was repeatedly emphasized in the Soviet period at the Pavlovsk Physiological Session of the USSR Academy of Sciences in 1950 and at congresses of hygienists.

In the Odessa period of scientific and pedagogical activity of H. V. Khlopin, the philosophical, prognostic approach of the scientist to the prospects of development of hygiene and the importance of sanitary-hygienic researches in the life of society were determined. Even at the dawn of modern hygiene, H. V. Khlopin drew attention to the sanitary protection of reservoirs and especially the coastal waters of the Black Sea. Along with the elucidation of the processes of selfpurification and the study of the influence of harmful substances on living organisms of the sea, the fundamental importance of H. V. Khlopin's works was that he experimentally studied the factors of water pollution, applied not only sanitary-chemical but also bacteriological and sanitary - toxicological research methods.

Hygiene scientists of Novorossiysk University (H. V. Khlopin, A. I. Rammul, K. E. Dobrovolskyi, K. K. Bogoliubov, N. F. Galanin, I. D. Kuptsys, V. A. Uglov, V. A. Yakovenko, etc.), in the late $19^{\text {th }}-$ early $20^{\text {th }}$ centuries, the scientific foundations of such preventive directions in medicine as communal hygiene, nutrition, military hygiene, school hygiene, etc. were laid. Hygienists in scientific development, on the one hand, took into account the latest achievements of European hygiene science, on the other - regional, historical, cultural, natural features that influenced the living and working conditions of the multinational population of the Russian Empire. The discoveries and scientific achievements of the scientists of the Department of Hygiene of Novorossiysk University were implemented in practical medicine, and the experimental researchers were directly involved in addressing the urgent needs of social health ${ }^{24}$.

${ }^{24}$ Kocur N. I. (2011). Stanovlennja i rozvytok ghighijenichnoji nauky v Ukrajini: shljakh krizj epokhy i socialjni potrjasinnja (drugha polovyna XIX-20-i rr. XX stolittja [Formation and development of hygienic science in Ukraine: a way through epochs and social upheavals (second half of XIX - 20th years of XX century: monograph]. Korsunj-Shevchenkivsjkyj, pp. 511-512. (in Ukrainian) 
Thus, the leading role in the development of hygiene science in the second half of the nineteenth - early twentieth century was played by the progressive views of scientists on finding ways to reduce morbidity and mortality precisely through the introduction of hygiene measures, the need for the organization of independent departments of hygiene, special training for sanitary and sanitary doctors.

\section{CONCLUSION}

The formation of the scientific foundations of sanitary and hygienic matter in the territory of Ukraine began with county medicine, which had not only medical but also sanitary and prophylactic orientation. The development of county medicine at a certain stage led to the emergence of a special sanitary organization, created a favorable ground for the combination of medical and preventive work.

The analysis of the county period of development of the sanitary and hygienic matter shows, first, the variety of issues that the counties in the sanitary plan (from sanitary statistics to the medical case) took care of; second, it differs in depth from the theoretical understanding of the practical tasks to be solved (from sanitary descriptions to research). Overcoming objective and subjective obstacles to the development of the sanitary and hygiene business, county doctors made invaluable sanitary and hygienic, anti-epidemic, educational contributions to the prevention and control of infectious diseases.

An important role in the formation and development of hygiene science was played by the departments of hygiene of universities of the Russian Empire - Kyiv St. Volodymyr, Kharkiv and Novorossiysk. Despite the existing socio-economic and political obstacles, Kyiv St. Volodymyr University became a leader in the development of domestic hygiene science, having created in 1865 the first hygiene department in the Russian Empire. Through the efforts of the head of the department, Professor V.A. Subotin, in sharp discussions of scientific circles of hygiene, she was distinguished into an independent scientific branch on health and disease prevention.

Departments of hygiene in its formation and development have passed several stages: from transitional - the proclamation of formation and artificial association in one structural subdivision of disciplines of different branches of medical science, to the proper hygienic 
department with a set of training courses, which in some modified form have reached our days were staffed by specialist hygienists.

The creation of hygiene departments was based on the latest achievements of foreign medicine. The heads of the departments and the leading teachers were trained in the most famous scientific centers of France, Germany, the USA, where they adopted the scientific experience and organizational principles of building a sanitary and hygienic case, which they introduced at home.

An important feature of scientific life was the publication of a series of textbooks and manuals on hygiene by V.A. Subotin, V. D. Orlov, A. I. Yakobii, I. P. Skvortsov, H. V. Khlopin, which for a long time remained methodological and methodical facilitated the qualitative preparation of hygienists at the medical faculties of the Kyiv St. Volodymyr University, Kharkiv and Novorossiysk Universities.

\section{SUMMARY}

The proposed article reveals the prerequisites for the formation and development of scientific foundations of sanitary and hygiene in the territory of Ukraine in the second half of the nineteenth - early twentieth century. These issues are important in the process of reforming the national health care system and improving prevention technologies.

In the course of the research, qualitative changes in structural and organizational components of hygienic science in the process of its formation and development, mutual influences and contradictions of county, university, scientific and public social medicine, personal measurement of scientific results, positioning of national hygienic science on the background of social, economic and political challenges of the second half of the nineteenth - twenties of the twentieth century. The process of formation of hygiene science as a social phenomenon, which, on the one hand, influenced the development of society, and, on the other, changed itself under the influence of political, economic and socio-cultural factors. The role of the scientist-hygienist in society from the perspective of the moral and ethical portrait of the era in which he lived and carried out scientific research is revealed, his social responsibility for human health is determined.

An important place in the mentioned research is given to the contribution of the first universities in Ukraine - Kyiv St.Volodymyr, 
Kharkiv and Novorossiysk in the formation and development of hygiene science. The process of establishing independent departments of hygiene at medical faculties is revealed, the contribution of scientists of hygienists - V. A. Subotin, V. D. Orlov, O. V. Korchak-Chepurkivskyi, A. I. Yakobii, I. P. Skvortsov, H. V. Khlopin in providing educational and methodological support at the departments of hygiene, training of hygienists, creation of the first domestic textbooks and manuals on hygiene.

\section{REFERENCES}

1. Bazhan T. A., Paran'ko N. M., Karnaukh N. (2005). O gigiene $i$ gigienistakh [About a hygiene and hygienists]. Dnepropetrovsk : Zhurfond. (in Ukrainian)

2. Bazanov V. A. (2009). Maks Pettenkofer i russkie gigienisty [Max Pettenkofer and Russian hygienisty]. Gigiena $i$ sanitariya. № 5. pp. 41-44. (in Russian)

3. Barannik P. I., Benyumov R. Ya., Makarenko I. M. (1962). V. A. Subbotin - organizator i rukovoditel' pervoy kafedry gigieny na Ukraine [V. A. Subbotin is an organizer and leader of the first department of hygiene on Ukraine] Materialy $k$ istorii gigieny $i$ sanitarii na Ukraine [Materialy to istorii gigieny I sanitarii na Ukraine] / pod red. D. N. Kalyuzhnogo, A. A. Grando. Kyiv, pp. 264-277. (in Ukrainian)

4. Ghrynzovsjkyj A. M. (2005). Systemnyj analiz stanovlennja i formuvannja medyko-profilaktychnogho fakuljtetu ta ghighijenichnoji nauky Nacionaljnogho medychnogho universytetu imeni O. O. Boghomoljcja [System analysis of formation and formation of the Faculty of Medicine and Prevention and Hygiene Science of the OO National Medical University The worshiper] (PhD Thesis), Kyiv: Kyjivsjkyj nacionaljnyj medychnyj universytet imeni O. O. Boghomoljcja. (in Ukrainian)

5. Zabludovskiy P. E. (1970). Puti razvitiya obshchestvennoy meditsiny [Ways of development of public medicine]. Moskva, pp. 71-73. (in Russian)

6. Zabludovsjkyj Ju. P. (1991). Istorija medycyny [History of medicine]. Kyiv. (in Ukrainian)

7. Ighumnov S.M. (1957). Narys rozvytku zemsjkoji medycyny na Ukrajini [Essay on the development of Zemsky medicine in Ukraine]. 
Materialy do istoriji rozvytku okhorony zdorov'ja na Ukrajini [Materials on the history of health care development in Ukraine] /Pid red. K. F. Duplenka. Kyiv: Derzhavne medychne vydavnyctvo URSO, pp. 124-168. (in Ukrainian)

8. Kagan S.S. (1965). K stoletiyu zemskoy meditsiny na Ukraine [To the century of zemskoy medicine on Ukraine]. Ocherki istorii russkoy obshchestvennoy mediny ( $K$ stoletiyu zemskoy meditsiny) [Essays of history of Russian public mediny (To the century of zemskoy medicine)]. M.: Meditsina, pp.85-91. (in Russian)

9. Kocur N. I. (2011). Stanovlennja i rozvytok ghighijenichnoji nauky v Ukrajini: shljakh krizj epokhy i socialjni potrjasinnja (drugha polovyna XIX - 20-i rr. XX stolittja [Formation and development of hygienic science in Ukraine: a way through epochs and social upheavals (second half of XIX - 20th years of XX century: monograph]. Korsunj-Shevchenkivsjkyj. (in Ukrainian)

10. Kryshtopa B. P. (1985). Vysshee meditsinskoe obrazovanie v Ukrainskoy SSR [Higher medical education is in Ukrainian SSR]. Kyiv. (in Ukrainian)

11. Orlov V. D. (1905) Posobie $k$ prakticheskim zanyatiyam po gigiene $i$ meditsinskoy politsii dlya studentov meditsinskogo fakul'teta Imperatorskogo Universiteta sv.Vladimira [Manual to practical employments on a hygiene and medical police for the students of medical faculty of Emperor's University sv. Vladimira]. Kyiv:Tipografiya Imeratorskogo U-ta sv.Vladimira. (in Ukrainian)

12. Orlov V. D. (1899). Viktor Andreevich Subbotin, kak uchenyy i professor [Victor Andrey Subbotin, as scientist and professor]. Universitetskie izv. № 2, pp. 246-259. (in Ukrainian)

13. Subbotin V. A. (1882). Kratkiy kurs gigieny profesora universitetu sv. Vladimira (sostavlen pri sodeystvii studentov 5-go kursa meditsinskogo fakul'teta) [Short-story course of hygiene to the profesora university sv. Vladimira (made at an assistance the students of 5th course of medical faculty)]. Kyiv : Tip. K. N. Milevskago. (in Ukrainian)

14. Subbotin V. A. (1883). Zapiski po gigiene [Messages on a hygiene]. Vyp. 1. Kyiv. (in Ukrainian)

15. Subbotin V. A. (1882). O rasshirenii prepodavaniya gigieny v russkikh universitetakhn [About expansion of teaching of hygiene in 
Russians of universitetakh]. Zdorov'e. № 10 (178) (okt.). pp. 231-254. (in Ukrainian)

16. Tomilin S. A. (1931). Sotsial'no-meditsinskaya profilaktika : teoreticheskoe obosnovanie $i$ prakticheskaya postanovka [Socialmedical prophylaxis : theoretical ground and practical raising]. Khar'kov : Gosmedizdat, USSR. (in Ukrainian)

17. Khlopin G. V. (1921). Osnovy gigieny [Bases of hygiene]. Moskva. (in Russian)

18. Yakobiy A. I. (1885). Kurs obshchestvenoy gigieny (napisano vid ruki, rozmnozheno litografichnim sposobom) [Course of obschestvenoy hygiene (otd hands are written, rozmnozheno by a lithographic method)]. Khar'kov. (in Ukrainian)

\section{Information about the author:} Nadiya Kotsur, Doctor of Historical Sciences (Ph. D.), Professor, Head of Department of Medical and Biological Disciplines and Valeology SHEI "Pereiaslav-Khmelnytskyi Hryhorii Skovoroda State Pedagogical University" 30, Sukhomlynskoho str., Pereiaslav-Khmelnytskyi,

Ukraine, 08401 ORCID ID: orcid.org/0000-0003-4720-2227 


\section{SOCIO-ECONOMIC AND ORGANIZATIONAL FACTORS OF POULTRY FARMING DEVELOPMENT IN THE UKRAINIAN SSR IN 1964-1971}

\section{Victoriia Melnyk}

\section{INTRODUCTION}

Public interest in the history of science, reassessment of existing stereotypes require a detailed inventory and rethinking of the depths of advanced scientific experience in the field of poultry, the use of which can be especially relevant when finding effective ways of further development of this field. The Ukrainian scientists have achieved considerable success both in the development of conceptual provisions of breeding and selection of agricultural poultry, as well as its feeding and keeping, established reputable scientific schools. In the early 60's of the 20th century already considerable experience of poultry enterprises working in countries abroad, including the USA ${ }^{1}$, France $^{2}$, $\mathrm{Japan}^{3}, \mathrm{USSR}^{4}$ and the Ukrainian $\mathrm{SSR}^{5}$. The need for research of industry priority achievements and creative achievements in the Ukrainian SSR in the 60's - early 70's of the 20th century. It is also conditioned by the fact that on the path of the history of poultry farming it was marked as a transition stage from extensive production to introduction of industrial high-intensity technologies, which provided

\footnotetext{
${ }^{1}$ Dahnovskij, N. V. (1959) Intensivnoe pticevodstvo v Soedinennyh Shtatah Ameriki [Intensive poultry farming in the United States]. Moscow, 127 s. (in Russian).

${ }^{2}$ Aleksandrov, A. D. (1960) Pticevodstvo vo Francii [Poultry in France]. Pticevodstvo, no. 11, pp. 45-47 (in Russian).

${ }^{3}$ Bozhko, P. E. (1963) Pticevodstvo Japonii [Poultry of Japan]. Pticevodstvo, no. № 9, pp. 30-32 (in Russian).

${ }^{4}$ Krjazh, I. Z. (1960) Opyt vyrashhivanija mjasnyh cypljat $v$ hozjajstvah Bol'sheNovoselkovskogo rajona [The experience of growing meat chickens in farms BolsheNovoselkovsky district]. Pticevodstvo, no. 8. S. 10-13 (in Russian).

${ }^{5}$ Samoletov, A. I., \& Karavaev, A. M. (1960). Kletochnoe soderzhanie kurnesushek na Tomilinskoj pticefabrike [Cage content of laying hens at Tomilinsky poultry farm]. Pticevodstvo, no. 8, pp. 6-10. (in Russian); Shajtan, B. I., \& Polishhuk, P. N. (1960) Organizacija pticevodstva v kolhoze «Kolos» [The organization of poultry farming at collective farm Kolos]. Pticevodstvo, no. 5, pp. 4-10 (in Russian).
} 
qualitative and quantitative growth of production of poultry products. Special literature provides information on the state of industrial poultry farming in the USSR during the period 1964-1971 ${ }^{6}$.

In our previous explorations, the scientific and organizational factors of the development of duck, goose and turkey breeding in the Ukrainian SSR in the second half of the 20th century are revealed ${ }^{7}$. However, due attention has not been paid to the study of the socioeconomic and organizational foundations of poultry development in the Ukrainian SSR in the period 1964-1971, which was marked by its transfer to an industrial basis.

The purpose of the work is to highlight the socio-economic and organizational factors of the formation and development of the industrial poultry sector in the Ukrainian SSR in 1964-1971.

\footnotetext{
${ }^{6}$ Pushkarenko, V., Lilevman, V. (1966). Kletochnaja batareja dlja vyrashhivanija utjat do 10 dnej [Cage battery for duckling for up to 10 days]. Pticevodstvo, no. 3 , pp. 27-29. (in Russian); Hachirashvili, G., \& Shperling, M. (1966) Kul'tura proizvodstva - osnova uspeha [The culture of production is the basis of success]. Pticevodstvo, no. 10, pp.4-9. (in Russian); Sergeev, V., Popov, A. (1970). Proizvodstvo mjasa brojlerov na kolhoznyh fermah [Production of broiler meat on collective farms]. Pticevodstvo, no. 9, pp. 14-15. (in Russian); Poplevkin, T. (1970) Mjasnoe pticevodstvo Ukrainy na podeme [Ukrainian meat poultry farming on the rise]. Pticevodstvo, no. 9, pp. 2-3.

${ }^{7}$ Meljnyk, V. V. (2018) Orghanizacijno-metodychna ta koordynacijna dijaljnistj Ukrajinsjkogho respublikansjkogho specializovanogho trestu ptakhofabryk $i$ ptakhoradghospiv v 1963-1964 rokakh [Organizational-methodical and coordination activity of the Ukrainian Republican Specialized Trust of Poultry Factories and Poultry Farms in 1963-1964]. Istorija nauky $i$ bioghrafistyka [History of Science and Biography Studies]: elektron. nauk. fakhove vyd, no. 3. URL: http://inb.dnsgb.com.ua/ 2018-3/07.pd. Accessed 25.05. 2018. (in Ukrainian); Meljnyk, V. V. (2018) Naukovoorghanizacijni zasady rozvytku indykivnyctva $v$ Ukrajinsjkij RSR u drughij polovyni $X X$ stolittja [Scientific and organizational principles of the development of turkey farming in the Ukrainian SSR in the second half of the twentieth century]. Ghileja: naukovyj visnyk, vyp. 135(N8), pp.67-71. (in Ukrainian); Meljnyk, V. V. (2018) Naukovo-orghanizacijni zasady rozvytku ghusivnyctva $v$ URSR u drughij polovyni $X X$ stolittja [Scientific and organizational principles of geese farming development in the Ukrainian SSR in the second half of the twentieth century]. Visnyk aghrarnoji istoriji: nauk. Zhurnal, vyp. 23-24, pp. 282-289. (in Ukrainian); Meljnyk, V. V. (2018) Naukovo-orghanizacijni zasady rozvytku kachkivnyctva $v$ Ukrajinsjkij RSR u drughij polovyni XX stolittja. [Scientific and organizational principles of duck farming development in the Ukrainian SSR in the second half of the twentieth century]. Eminak: naukovyj shhokvartaljnyk, no. 4(24), vol. 2, pp. 177-181. (in Ukrainian).
} 


\section{Socio-economic factors of poultry development in the Ukrainian SSR in 1964-1971}

Production of poultry products in the USSR in the early 60's of the last century was concentrated in the public sector and in households. If in $196115 \%$ of the total number of eggs were produced in state-owned enterprises of the USSR, then in 1964 this figure increased to $17 \%^{8}$. According to statistics, the rest of the eggs were produced in farms of the rural population. Due to the rapid growth of urban population in the USSR and the Ukrainian SSR in the second half of the 20th century, there was an urgent problem of providing urban residents with food. As noted in our previous publications, its percentage in 1952 was 39, and as of January 1, 1963, it increased to $50^{9}$. In this regard, in January 1963 approved the resolution of the CPSU Central Committee and the Council of Ministers of the USSR "On the increase in production of eggs and poultry in suburban areas of large cities and industrial centers", which preceded the resolution adopted in 1964 by the CPSU Central Committee and Council of Ministers of the USSR "On the Organization of Production of Eggs and Poultry Meat on an Industrial Basis" $"$. In accordance with their decisions, the Council of Ministers of the Union Republics and the State Building of the USSR pledged to ensure the commissioning of poultry farms and poultry farms with an annual capacity of enterprises for 20-40 million eggs or 1-2 million

${ }^{8}$ Statistika, (1965). Narodne ghospodarstvo Ukrajinsjkoji RSR v 1964 roci: statystychnyj shhorichnyk [People's economy of the Ukrainian SSR in 1964: statistical yearbook]. Kyiv, 694 s. (in Ukrainian).

${ }^{9}$ Meljnyk, V. V. (2017) Socialjno-ekonomichni ta politychni peredumovy stanovlennja promyslovogho ptakhivnyctva v USSR (1953-1964). [Socio-economic and political preconditions for the establishment of industrial poultry farming in the Ukrainian SSR (1953-1964)]. Istorija nauky i bioghrafistyka [History of Science and Biography Studies]: elektron. nauk. fakhove vyd, no. 2 URL: http://inb.dnsgb.com.ua/ 2017-2/07.pd. Accessed 15.04. 2018 (in Ukrainian).

${ }^{10}$ Izvestija, (1985). Ob uvelichenii, 1985 - Ob uvelichenii proizvodstva jaic i mjasa pticy $v$ prigorodnyh zonah krupnyh gorodov i promyshlennyh centrov: Postanovlenie Central'nogo Komiteta KPSS $i$ Soveta ministrov SSSR ot 8 janvarja $1963 \mathrm{~g}$. [On increasing the production of eggs and poultry meat in the suburban areas of major cities and industrial centers: Resolution of the Central Committee of the CPSU and the Council of Ministers of the USSR of January 8, 1963], № 30. Svod zakonov SSSR. Moscow, vol. 7, pp. 519-520. (in Russian). 
broilers for one and a half or two years, and more - within two to three years from the beginning of construction. Decisions were made to organize the USSR Poultry Industry Department to manage specialized poultry farms, and in the Union republics the poultry industry departments or poultry trusts ${ }^{11}$. It should be noted that prior to the establishment of the Department of the Poultry Industry of the USSR, the coordination of this work was carried out by the Ukrainian Republican specialized trust of poultry farms and poultry farms, whose organizational and methodical activity in 1963-1964 was covered in the article. Poultry industry of the Ukrainian SSR, poultry industry management and poultry trusts of the Union republics performed the following functions:

1) production of eggs and poultry meat on an industrial basis, implementation of plans for sale to the state of these products by poultry enterprises;

2) organization of breeding, hybridization of poultry, breeding work in poultry farms and in the network of specialized farms, provision of poultry farms and farms with high-performance breeding and hybrid poultry;

3) development of compound feed recipes, control over production organization and quality of compound feed for poultry and ensuring its effective use;

4) introduction of advanced methods of organization of industrial poultry farming and modern technology of egg incubation, technology of keeping and care of poultry, as well as technology of poultry processing;

5) search for the most rational forms of organization and normalization of labor, wide introduction of mechanization of production processes;

${ }^{11}$ Meljnyk, V. V. (2018) Orghanizacijno-metodychna ta koordynacijna dijaljnistj Ukrajinsjkogho respublikansjkogho specializovanogho trestu ptakhofabryk $i$ ptakhoradghospiv $v$ 1963-1964 rokakh [Organizational-methodical and coordination activity of the Ukrainian Republican Specialized Trust of Poultry Factories and Poultry Farms in 1963-1964]. Istorija nauky i bioghrafistyka [History of Science and Biography Studies]: elektron. nauk. fakhove vyd, no. 3. URL: http://inb.dnsgb.com.ua/20183/07.pd. Accessed 25.05. 2018. (in Ukrainian). 
6) selection and placement of management personnel and specialists, training of poultry experts, as well as upgrading the skills of poultry workers;

7) approval in the prescribed manner of the structure and typical staffs of poultry farms, poultry farms, breeding farms, poultry stations and other enterprises and organizations ${ }^{12}$.

As a result of our research, in the Ukrainian SSR, industrial poultry farming was developing at a rapid pace, along with the development of the entire economy. According to statistics, gross industrial production in 1971 increased by 1.6 times compared to 1965 , and agriculture by 1.2 times $^{13}$. In 1971 , relative to 1965 , the capital investments of state and cooperative enterprises increased by $146 \%$, the gross public product - by $148 \%$, the national income - by $146 \%$, the average wages of workers and employees - by $126 \%$, the wages of collective farmers - by $142 \%{ }^{14}$. Production per capita increased as well. Thus, in 1965, 153 eggs were produced, and in 1970 - 195 per capita, respectively, of meat of all types 49 and $60 \mathrm{~kg}^{15}$. Due to the increasing trend of urban population growth in the Ukrainian SSR in the 1970's (in 1971 it was $56 \%$ of the total population), it was decided to accelerate the organization of production of eggs and poultry on an industrial basis ${ }^{16}$. Large-scale poultry farms, as well as specialized

${ }^{12}$ Izvestija, (1985). Ob organizacii proizvodstva jaic i mjasa pticy na promyshlennoj osnove: Postanovlenie Soveta Ministrov SSSR i Central'nogo Komiteta KPSS ot 3 sentjabrja $1964 \mathrm{~g}$. [On the organization of the production of eggs and poultry meat on an industrial basis: Resolution of the Council of Ministers of the USSR and the Central Committee of the CPSU of September 3, 1964], № 740. Svod zakonov SSSR. Moscow, vol. 7, pp. 512-517. (in Russian).

${ }^{13}$ Statistika, (1976). Narodnoe hozjajstvo Ukrainskoj SSR v 1975 godu: statisticheskij ezhegodnik [People's Economy of the Ukrainian SSR in 1975: a statistical yearbook]. Kiev, 540 s. (in Russian).

${ }^{14}$ Statistika, (1974). Narodnoe hozjajstvo Ukrainskoj SSR v 1973 godu: statisticheskij ezhegodnik [People's Economy of the Ukrainian SSR in 1973: a statistical yearbook]. Kiev, 584 s. (in Russian).

${ }^{15}$ Statistika, (1976). Narodnoe hozjajstvo Ukrainskoj SSR v 1975 godu: statisticheskij ezhegodnik [People's Economy of the Ukrainian SSR in 1975: a statistical yearbook]. Kiev, 540 s. (in Russian).

16 Statistika, (1976). Narodnoe hozjajstvo Ukrainskoj SSR v 1975 godu: statisticheskij ezhegodnik [People's Economy of the Ukrainian SSR in 1975: a statistical yearbook]. Kiev, 540 s. (in Russian). 
farms became the organizational form of intensive industrial poultry farming. One of the largest poultry farms not only in the Ukrainian SSR, but also in the USSR, which specialized in the production of chicken food eggs, became the poultry farm "Yuzna" of the Crimean region, organized in 1965 on the basis of the state farm "Yuzhnyi". The farm was created in 1960 on the basis of the merger of three multisectoral farms. In the "Yuzhnyi" State Farm, besides poultry, they kept cattle, pigs, sheep, engaged in grain production, horticulture, viticulture, tobacco, and cultivation of essential oil crops ${ }^{17}$. The names of workers of this poultry farm A. Hetman, V. Kozina, M. Stocklos, M. Sidelnikov and others, who served thousands of laying hens in cage batteries, provided high livestock conservation and productivity, became known far beyond the Ukrainian SSR ${ }^{18}$. The management of the poultry farm was carried out by Director G. Khachirashvili, based on the strengthening of the role of economic methods of management, improvement of planning, expansion of economic autonomy and initiatives of the collectives of enterprises, increase of its material interest $^{19}$.

In the Ukrainian SSR of the studied period, egg poultry intensively developed. During five years after the official transfer of the industry to the industrial base in the country, 17 egg production poultry farms were built. The number of laying hens from 1966 to 1972 increased by 1.7 times in collective farms, state farms and other state-owned enterprises of the Ukrainian SSR, which resulted in a 3.6-fold increase in the production of poultry eggs ${ }^{20}$. It should be noted that among the Soviet republics of the USSR, the greatest successes in the development of meat poultry during the period under review were the Ukrainian

\footnotetext{
${ }^{17}$ Hachirashvili, G., \& Shperling, M. (1966) Ukrepljat' tehnologicheskuju disciplinu, povyshat' rentabel'nost' proizvodstva [Strengthen technological discipline, increase the profitability of production]. Pticevodstvo, no. 1, pp. 7-9. (in Russian).

${ }^{18} \mathrm{~V}$ kollektive geroev [In the team of heroes]. (1966) Pticevodstvo, no. 10. S. 2-4. (in Russian).

${ }^{19}$ Hachirashvili, G., \& Shperling, M. (1966) Ukrepljat' tehnologicheskuju disciplinu, povyshat' rentabel'nost' proizvodstva [Strengthen technological discipline, increase the profitability of production]. Pticevodstvo, no. 1, pp. 7-9. (in Russian).

${ }^{20}$ Statistika, (1974). Narodnoe hozjajstvo Ukrainskoj SSR v 1973 godu: statisticheskij ezhegodnik [People's Economy of the Ukrainian SSR in 1973: a statistical yearbook]. Kiev, 584 s. (in Russian).
} 
SSR. This was facilitated by the commissioning of five poultry farms of productivity in the system of the Main Poultry Trust in the Ukrainian $\mathrm{SSR}^{21}$. As a result of using their facilities and attracting other reserves of poultry farming, the production of poultry meat increased by 1.9 times from 1964 to $1971^{22}$. Already during this period, it became apparent that significant reserves for increasing poultry meat production were precisely in broiler production. With a view to its development, in 1962 the state farm "Krasnyi" (Crimean region) put into operation the first, not only in the Ukrainian SSR, but also in the USSR, an experimental broiler factory for the production of poultry meat on an industrial basis ${ }^{23}$. The poultry farm was restructured to produce poultry meat for meat production. For the first time in the Crimean region a complex of highly specialized farms was created in the Ukrainian SSR, which worked according to the plan of a single technological process on the basis of industrial cooperation ${ }^{24}$. Scientific and organizational support for the development of meat poultry breeding in the USSR was carried out by scientists of the Ukrainian Poultry Research Station, which in 1959 was reorganized into the Ukrainian Research Institute of Poultry Breeding by the order of the Ukrainian Academy of Agricultural Sciences ${ }^{25}$.

\section{Organizational factors of poultry development in the Ukrainian SSR of study period}

Scientists of the Crimean Branch of the Ukrainian Poultry Research Institute together with the collective of specialists of the state

${ }^{21}$ Kirin, I. (1970) Puti uvelichenija proizvodstva mjasa pticy [Ways to increase poultry production]. Pticevodstvo, no. 10, pp. 13-14. (in Russian).

${ }^{22}$ Statistika, (1966). Narodne ghospodarstvo Ukrajinsjkoji RSR v 1965 roci: statystychnyj shhorichnyk [People's economy of the Ukrainian SSR in 1965: statistical yearbook]. Kyiv, 715 s. (in Ukrainian).

${ }^{23}$ Marchik, V., \& Bronfman, E. (1970) Brojlernaja fabrika $v$ sodruzhestve $s$ kolhozami [Broiler factory in cooperation with collective farms]. Pticevodstvo, no. 9, pp. 12-13. (in Russian).

${ }^{24}$ Poplevkin, T. (1970) Mjasnoe pticevodstvo Ukrainy na pod eme [Ukrainian meat poultry farming on the rise]. Pticevodstvo, no. 9, pp. 2-3.

${ }^{25}$ Centraljnyj derzhavnyj arkhiv vyshhykh orghaniv vlady [Central State Archive of the Supreme Power and Administration of Ukraine], f. P-4861, d. 1, c. 2139, pp. 84-89. (in Ukrainian). 
farm "Krasnyi" for the first time in the Soviet Union developed the technology of growing broiler chickens, which in the future worked almost all poultry farms in the Ukrainian SSR. As it was developed on the farm, broiler meat production increased and financial performance improved. Thus, from 1967 to 1969, meat production in the state farm Krasnyi increased by $29.3 \%$ and the profitability of production 5.8 times $^{26}$. At the initiative and direct participation of the staff of the Ukrainian Poultry Research Institute and specialists of the state farm "Krasnyi" in the collective farm "Progress" of the Pavlograd region of Dnipropetrovsk region in 1968 broiler production was organized on an industrial basis, and in 1969 broiler production was decided on farms of the Crimean region ${ }^{27}$. At the same time, they provided practical assistance to collective and state farms on the supply of hybrid eggs from high-performance meat lines of chickens, developed compound feeds for broilers, issued scientific and practical recommendations on the technology of production of broiler meat, training of poultry. Thus, in 1970 on the basis of the state farm "Krasnyi" seminars for zootechnics of collective farms and hatchery-poultry stations of the Crimean region were held, at which more than 30 representatives from 6 collective farms underwent 20-day training ${ }^{28}$.

Successful development of poultry in the Ukrainian SSR after its transfer to the industrial base, had a positive impact on the socioeconomic status of the population. So, for example, in the republic at that time meat for catering and sale to workers and employees of state farms was released on limits from the state resources which were available to areas for delivery to the population. In 1969, the planned cost of poultry (chicken) in the system of the Ministry of State Farms of the USSR was lower than its retail price by $11.3 \%$. They implemented it for catering and sale to workers and employees of state farms at the

\footnotetext{
${ }^{26}$ Marchik, V., \& Bronfman, E. (1970) Brojlernaja fabrika $v$ sodruzhestve $s$ kolhozami [Broiler factory in cooperation with collective farms]. Pticevodstvo, no. 9, pp. 12-13. (in Russian).

${ }^{27}$ Sergeev, V., Popov, A. (1970). Proizvodstvo mjasa brojlerov na kolhoznyh fermah [Production of broiler meat on collective farms]. Pticevodstvo, no. 9, pp. 14-15. (in Russian).

${ }^{28}$ Marchik, V., \& Bronfman, E. (1970) Brojlernaja fabrika $v$ sodruzhestve $s$ kolhozami [Broiler factory in cooperation with collective farms]. Pticevodstvo, no. 9, pp. 12-13. (in Russian).
} 
planned $\operatorname{cost}^{29}$. This testified to the high economic efficiency of chicken production in farms. However, according to archival documents, the meat used in state farms for catering and sale, by its quality was much worse than that handed over to the state, this is explained by the fact that state farms sold a large part of the meat from forced slaughter animals $^{30}$.

We have found that for the production of poultry meat in the USSR, reserves duck, turkey were used ${ }^{31}$. Specifically, poultry in the republic was considered an important reserve for the industrial production of poultry meat. The rapid development of this industry in the USSR was facilitated by the popularization of the experience of the Yagotin Poultry Factory (Kyiv region), where for the first time they mastered the technology of growing ducklings for meat without the use of reservoirs. This poultry farm has become a school of excellence in the implementation of industrial breeding ${ }^{32}$. In 1965, a mechanized cage battery for growing ducklings up to 10 days of age was first manufactured and tested by the specialists of the South Ukrainian State Zonal Machine-Building Station (Kherson). Previously, ducklings were grown in cage batteries intended for growing chickens ${ }^{33}$.

${ }^{29}$ Centraljnyj derzhavnyj arkhiv vyshhykh orghaniv vlady [Central State Archive of the Supreme Power and Administration of Ukraine], f. P-2, d. 13, c. 5088, pp. 72-75. (in Ukrainian).

${ }^{30}$ Centraljnyj derzhavnyj arkhiv vyshhykh orghaniv vlady [Central State Archive of the Supreme Power and Administration of Ukraine], f. P-2, d. 13, c. 5088, pp. 72-75. (in Ukrainian).

${ }^{31}$ Meljnyk, V. V. (2018) Naukovo-orghanizacijni zasady rozvytku ghusivnyctva $v$ URSR u drughij polovyni XX stolittja [Scientific and organizational principles of geese farming development in the Ukrainian SSR in the second half of the twentieth century]. Visnyk aghrarnoji istoriji: nauk. zhurnal, vyp. 23-24, pp. 282-289. (in Ukrainian); Meljnyk, V. V. (2018) Naukovo-orghanizacijni zasady rozvytku indykivnyctva $v$ Ukrajinsjkij RSR u drughij polovyni XX stolittja [Scientific and organizational principles of the development of turkey farming in the Ukrainian SSR in the second half of the twentieth century]. Ghileja: naukovyj visnyk, vyp. 135(N8), pp. 67-71. (in Ukrainian).

${ }^{32}$ Kirin, I. (1970) Puti uvelichenija proizvodstva mjasa pticy [Ways to increase poultry production]. Pticevodstvo, no. 10, pp. 13-14. (in Russian).

${ }^{33}$ Pushkarenko, V., Lilevman, V. (1966). Kletochnaja batareja dlja vyrashhivanija utjat do 10 dnej [Cage battery for duckling for up to 10 days]. Pticevodstvo, no. 3, pp. 27-29. (in Russian). 
In general, these measures helped to increase the production of poultry meat, and mobilized a meat poultry reserve such as duckling. And, if in the system of farms of the Main Poultry Trust of the Ukrainian SSR in 1964 the share of duck meat production from the total production of poultry meat was 25\%, then in 1969 this figure increased to $41 \%{ }^{34}$. An important role in the development of industrial poultry in the Ukrainian SSR, like the entire USSR, was played by the 13th World Poultry Congress, held in Kiev on August 15, 1966 ${ }^{35}$. It facilitated friendly relations between poultry breeders from all over the world, strengthened business contacts and improved the exchange of scientific information. We found that during the study period there was an increase in concentration of production with advanced specialization, which improved the organization of technological process, labor, allowed better use of feed, which in general provided an increase in production of poultry products and a decrease in its cost. Thus, as of January 1, 1970, 820 farms in the Ukrainian SSR specialized in the production of eggs and poultry, including the production of eggs 745 and meat $-75^{36}$. Resolution of the Central Committee of the CPSU and the Council of Ministers of the USSR of July 16, 1970, decided to increase the production of full-fledged and cheap animal feeds by increasing the production of grain forage crops and increasing crop yields, as well as expanding the acreage of corn, legumes, soybeans and other crops in in areas where they produce high yields ${ }^{37}$. This decision was also important for the development of industrial poultry farming in the Ukrainian SSR, as the provision of full-fledged poultry feeds in farms has become a key chain in the

\footnotetext{
${ }^{34}$ Kirin, I. (1970) Puti uvelichenija proizvodstva mjasa pticy [Ways to increase poultry production]. Pticevodstvo, no. 10, pp. 13-14. (in Russian).

${ }^{35}$ Forum pticevodov [Forum poultry breeders]. (1966). Pticevodstvo, no. 5, pp. 10-11. (in Russian).

${ }^{36}$ Centraljnyj derzhavnyj arkhiv vyshhykh orghaniv vlady [Central State Archive of the Supreme Power and Administration of Ukraine], f. P-2, d. 13, c. 5088, pp. 72-75. (in Ukrainian).

${ }^{37}$ Izvestija, (1985). O merah po uvelicheniju proizvodstva i uluchsheniju kachestva kormov. Postanovlenie Central'nogo Komiteta KPSS $i$ Soveta Ministrov SSSR ot 16 ijulja $1970 \mathrm{~g}$. [On measures to increase production and improve the quality of feed. Resolution of the Central Committee of the CPSU and the Council of Ministers of the USSR of July 16, 1970], № 554. Svod zakonov SSSR. Moscow, vol. 7, pp. 530-531. (in Russian).
} 
production of eggs and meat. There was a need to put into operation new poultry farms and other state poultry farms, to introduce advanced technologies for the intensification of the poultry industry. In this regard, a decree was adopted in 1971: "Measures to further increase the production of eggs and poultry on an industrial basis". According to its decisions, it was required to use lightweight prefabricated and other modern designs of industrial poultry farming for poultry construction. One of the important points of the resolution is the obligation of the Council of Ministers of the Union Republics to establish annual tasks for the removal of young poultry at state and inter-farm poultry stations and poultry farms for the purpose of full provision of collective farms, livestock farms ${ }^{38}$. First of all, it was envisaged to create favorable conditions for the further accelerated construction of new poultry houses, the use of full-fledged compound feeds in poultry feeding, which allowed to apply complex mechanization and reduce labor costs for production of eggs and poultry meat. All these organizational measures were aimed at increasing the production of poultry products in order to provide the population with dietary food.

\section{CONCLUSIONS}

Thus, the formation and development of industrial poultry in the Ukrainian SSR in 1964-1971 was provided with favorable socioeconomic and organizational factors. The development of the industry occurred simultaneously with the rise of industry and the growth of gross public product, national income, wages of workers, employees and collective farmers, etc. The number of urban population was increasing, which became one of the prerequisites for the establishment of specialized industrial farms around the big cities and industrial centers of the republic - poultry farms for supplying the population with eggs and poultry meat. The production of poultry products was also organized on specialized farms of collective farms. During this

\footnotetext{
${ }^{38}$ Izvestija, (1985). O merah po dal'nejshemu uvelicheniju proizvodstva jaic i mjasa pticy na promyshlennoj osnove. Postanovlenie Central'nogo Komiteta KPSS i Soveta Ministrov SSSR ot 26 fevralja $1971 \mathrm{~g}$. [On measures to further increase the production of eggs and poultry meat on an industrial basis. Resolution of the Central Committee of the CPSU and the Council of Ministers of the USSR of February 26, 1971], № 165. Svod zakonov SSSR. Moscow, vol. 7, pp. 517-519. (in Russian).
} 
period, poultry farms operated in the USSR, which gained the fame of the most powerful specialized enterprises of the USSR, in particular, the state farm Krasnyi (Crimea region), poultry farms Yagotinska and Starynska (Kyiv region). The poultry industry of the studied period is characterized by deepening of specialization and concentration of production. The increase in the number of poultry in the USSR, as well as the production of eggs and poultry meat was facilitated by the relevant resolutions of the CPSU Central Committee and the Council of Ministers of the Ukrainian SSR, which regulated a number of urgent organizational measures. Scientific and organizational support of the industrial poultry industry in the Ukrainian SSR of this period was carried out by scientists of the Ukrainian Poultry Research Institute.

Prospects for further exploration are to study the scientific, organizational and socio-economic foundations of poultry development in the Ukrainian SSR in 1971-1990.

\section{SUMMARY}

The purpose of article is to highlight the influence of socioeconomic and organizational factors of the formation and development of the industrial sector of poultry farming in the Ukrainian SSR in 1964-1971. The research methodology is based on the general scientific principles of historical authenticity, objectivity, systemicity, complexity, and scientific. The author used general scientific, interdisciplinary and special historical methods, as well as a diverse source base, which is based on archival documents that reveal the main tendencies of the transfer of poultry farming to an industrial basis.

The scientific novelty of the article is to carry out a holistic analysis of the formation of the industrial sector of poultry farming in the context of socio-economic and organizational factors. The author first has proved that the development of this branch occurred simultaneously with the rise of industry and the increase of gross social product, national income, wages of workers, employees and collective farmers, etc.

It has established that an increase in the urban population in the $60-70$ 's of the 20th century was the prerequisite for the creation of specialized farms of industrial type around the big cities and industrial centres of the Ukrainian SSR - poultry farms for supplying the population with food eggs and poultry meat. It has shown that during 
this period poultry farms operating in the republic, which got the status of the most powerful specialized enterprises of the Ukrainian SSR, functioned in the republic. They included to its the state farm "Krasnyi" (Crimean region), poultry farms "Yagotynska" and "Starynska" (Kiev region). As the main features of the poultry industry of the investigated period, the author considered the specialization and concentration of production. The article demonstrates that the corresponding decisions of the Central Committee of the CPSU and the Council of Ministers of the USSR, which regulated a number of urgent organizational measures, have became the basis for the transition of the branch to the industrial base, contributed to the increase of the poultry stock in the Ukrainian SSR, as well as the production of eggs and meat. The scientific-organizational and scientific-methodological support of the poultry industry in the Ukrainian SSR in 1964-1971 was carried out by scientists of the Ukrainian Research Institute of Poultry Farming.

\section{REFERENCES}

1. Aleksandrov, A. D. (1960) Pticevodstvo vo Francii [Poultry in France]. Pticevodstvo, no. 11, pp. 45-47. (in Russian).

2. Bozhko, P. E. (1963) Pticevodstvo Japonii [Poultry of Japan]. Pticevodstvo, no. № 9, pp. 30-32. (in Russian).

3. V kollektive geroev [In the team of heroes]. (1966) Pticevodstvo, no. 10. S. 2-4. (in Russian).

4. Dahnovskij, N. V. (1959) Intensivnoe pticevodstvo v Soedinennyh Shtatah Ameriki [Intensive poultry farming in the United States]. Moscow, 127 s. (in Russian).

5. Izvestija, (1985). O merah po uvelicheniju proizvodstva $i$ uluchsheniju kachestva kormov. Postanovlenie Central'nogo Komiteta KPSS i Soveta Ministrov SSSR ot 16 ijulja $1970 \mathrm{~g}$. [On measures to increase production and improve the quality of feed. Resolution of the Central Committee of the CPSU and the Council of Ministers of the USSR of July 16, 1970], № 554. Svod zakonov SSSR. Moscow, vol. 7, pp. 530-531. (in Russian).

6. Izvestija, (1985). O merah po dal'nejshemu uvelicheniju proizvodstva jaic i mjasa pticy na promyshlennoj osnove. Postanovlenie Central'nogo Komiteta KPSS i Soveta Ministrov SSSR ot 26 fevralja $1971 \mathrm{~g}$. [On measures to further increase the production of eggs and poultry meat on an industrial basis. Resolution of the Central 
Committee of the CPSU and the Council of Ministers of the USSR of February 26, 1971], № 165. Svod zakonov SSSR. Moscow, vol. 7, pp. 517-519. (in Russian).

7. Izvestija, (1985). Ob organizacii proizvodstva jaic i mjasa pticy na promyshlennoj osnove: Postanovlenie Soveta Ministrov SSSR $i$ Central'nogo Komiteta KPSS ot 3 sentjabrja $1964 \mathrm{~g}$. [On the organization of the production of eggs and poultry meat on an industrial basis: Resolution of the Council of Ministers of the USSR and the Central Committee of the CPSU of September 3, 1964], № 740. Svod zakonov SSSR. Moscow, vol. 7, pp. 512-517. (in Russian).

8. Izvestija, (1985). Ob uvelichenii proizvodstva jaic i mjasa pticy $v$ prigorodnyh zonah krupnyh gorodov $i$ promyshlennyh centrov: Postanovlenie Central'nogo Komiteta KPSS i Soveta ministrov SSSR ot 8 janvarja $1963 \mathrm{~g}$. [On increasing the production of eggs and poultry meat in the suburban areas of major cities and industrial centers: Resolution of the Central Committee of the CPSU and the Council of Ministers of the USSR of January 8, 1963], № 30. Svod zakonov SSSR. Moscow, vol. 7, pp. 519-520. (in Russian).

9. Kirin, I. (1970) Puti uvelichenija proizvodstva mjasa pticy [Ways to increase poultry production]. Pticevodstvo, no. 10, pp. 13-14. (in Russian).

10. Krjazh, I. Z. (1960) Opyt vyrashhivanija mjasnyh cypljat v hozjajstvah Bol'she-Novoselkovskogo rajona [The experience of growing meat chickens in farms Bolshe-Novoselkovsky district]. Pticevodstvo, no. 8. S. 10-13. (in Russian).

11. Marchik, V., \& Bronfman, E. (1970) Brojlernaja fabrika $v$ sodruzhestve s kolhozami [Broiler factory in cooperation with collective farms]. Pticevodstvo, no. 9, pp. 12-13. (in Russian).

12. Meksin, D. (1966) Oni byli delegatami sezda [They were delegates to the convention]. Pticevodstvo, no.6, pp. 6-9. (in Russian).

13. Meljnyk, V. V. (2017) Socialjno-ekonomichni ta politychni peredumovy stanovlennja promyslovogho ptakhivnyctva $v$ USSR (1953-1964). [Socio-economic and political preconditions for the establishment of industrial poultry farming in the Ukrainian SSR (1953-1964)]. Istorija nauky i bioghrafistyka [History of Science and Biography Studies]: elektron. nauk. fakhove vyd, no. 2 URL: http://inb.dnsgb.com.ua/2017-2/07.pd. Accessed 15.04. 2018 (in Ukrainian). 
14. Meljnyk, V. V. (2018) Orghanizacijno-metodychna ta koordynacijna dijaljnistj Ukrajinsjkogho respublikansjkogho specializovanogho trestu ptakhofabryk $i$ ptakhoradghospiv $v$ 1963-1964 rokakh [Organizational-methodical and coordination activity of the Ukrainian Republican Specialized Trust of Poultry Factories and Poultry Farms in 1963-1964]. Istorija nauky $i$ bioghrafistyka [History of Science and Biography Studies]: elektron. nauk. fakhove vyd, no. 3. URL: http://inb.dnsgb.com.ua/2018-3/07.pd. Accessed 25.05. 2018. (in Ukrainian).

15. Meljnyk, V.V. (2018) Naukovo-orghanizacijni zasady rozvytku indykivnyctva $v$ Ukrajinsjkij RSR u drughij polovyni $X X$ stolittja [Scientific and organizational principles of the development of turkey farming in the Ukrainian SSR in the second half of the twentieth century]. Ghileja: naukovyj visnyk, vyp. 135(N 8), pp. 67-71. (in Ukrainian).

16. Meljnyk, V. V. (2018) Naukovo-orghanizacijni zasady rozvytku ghusivnyctva $v$ URSR u drughij polovyni XX stolittja [Scientific and organizational principles of geese farming development in the Ukrainian SSR in the second half of the twentieth century]. Visnyk aghrarnoji istoriji: nauk. Zhurnal, vyp. 23-24, pp. 282-289. (in Ukrainian).

17. Meljnyk, V.V. (2018) Naukovo-orghanizacijni zasady rozvytku kachkivnyctva $v$ Ukrajinsjkij RSR u drughij polovyni $X X$ stolittja. [Scientific and organizational principles of duck farming development in the Ukrainian SSR in the second half of the twentieth century]. Eminak: naukovyj shhokvartaljnyk, no. 4(24), vol. 2, pp. 177-181. (in Ukrainian).

18. Nechaev, N.P. (1966) Poezdka v Kanadu $i$ SShA [Trip to Canada and USA]. Pticevodstvo, no. 3, pp. 32-35. (in Russian).

19. Nikulin, I. P. (1963) Mezhkolhoznye fermy v Kirovskoj oblasti [Inter-farm farms in the Kirov region]. Pticevodstvo, no. 10, pp. 4-5. (in Russian).

20. Oleksenko, G., Anishhenko, V., \& Dalin, V. (1966) Proizvodstvo jaic $i$ ptich'ego mjasa $v$ kolhozah Cherkasshhiny [Production of eggs and poultry meat on collective farms of Cherkasy region]. Pticevodstvo, no. 6, pp. 12-13. (in Russian).

21. Pokid'ko, A.I. (1963) Pticeferma "Rodina” [Poultry Farm Motherland]. Pticevodstvo, no. 10, pp. 6. (in Russian). 
22. Poplevkin, T. (1970) Mjasnoe pticevodstvo Ukrainy na pod'eme [Ukrainian meat poultry farming on the rise]. Pticevodstvo, no. 9 , pp. 2-3.

23. Pushkarenko, V., Lilevman, V. (1966). Kletochnaja batareja dlja vyrashhivanija utjat do 10 dnej [Cage battery for duckling for up to 10 days]. Pticevodstvo, no. 3, pp. 27-29. (in Russian).

24. Samoletov, A. I., \& Karavaev, A. M. (1960). Kletochnoe soderzhanie kur-nesushek na Tomilinskoj pticefabrike [Cage content of laying hens at Tomilinsky poultry farm]. Pticevodstvo, no. 8, pp. 6-10. (in Russian).

25. Sergeev, V. (1966). Iskusstvennoe osemenenie utok v Japonii [Artificial insemination of ducks in Japan]. Pticevodstvo, no. 10, pp. 33-35. (in Russian).

26. Sergeev, V., Popov, A. (1970). Proizvodstvo mjasa brojlerov na kolhoznyh fermah [Production of broiler meat on collective farms]. Pticevodstvo, no. 9, pp. 14-15. (in Russian).

27. Statistika, (1965). Narodne ghospodarstvo Ukrajinsjkoji RSR v 1964 roci: statystychnyj shhorichnyk [People's economy of the Ukrainian SSR in 1964: statistical yearbook]. Kyiv, 694 s. (in Ukrainian).

28. Statistika, (1966). Narodne ghospodarstvo Ukrajinsjkoji RSR v 1965 roci: statystychnyj shhorichnyk [People's economy of the Ukrainian SSR in 1965: statistical yearbook]. Kyiv, 715 s. (in Ukrainian).

29. Statistika, (1974). Narodnoe hozjajstvo Ukrainskoj SSR v 1973 godu: statisticheskij ezhegodnik [People's Economy of the Ukrainian SSR in 1973: a statistical yearbook]. Kiev, 584 s. (in Russian).

30. Statistika, (1976). Narodnoe hozjajstvo Ukrainskoj SSR v 1975 godu: statisticheskij ezhegodnik [People's Economy of the Ukrainian SSR in 1975: a statistical yearbook]. Kiev, $540 \mathrm{~s}$. (in Russian).

31. Forum pticevodov [Forum poultry breeders]. (1966). Pticevodstvo, no. 5, pp. 10-11. (in Russian).

32. Hachirashvili, G., \& Shperling, M. (1966) Ukrepljat' tehnologicheskuju disciplinu, povyshat' rentabel'nost' proizvodstva [Strengthen technological discipline, increase the profitability of production]. Pticevodstvo, no. 1, pp. 7-9. (in Russian). 
33. Hachirashvili, G., \& Shperling, M. (1966) Kul'tura proizvodstva - osnova uspeha [The culture of production is the basis of success]. Pticevodstvo, no. 10, pp. 4-9. (in Russian).

34. Centraljnyj derzhavnyj arkhiv vyshhykh orghaniv vlady [Central State Archive of the Supreme Power and Administration of Ukraine], f. P-4861, d. 1, c. 2139, pp. 84-89. (in Ukrainian).

35. Centraljnyj derzhavnyj arkhiv vyshhykh orghaniv vlady [Central State Archive of the Supreme Power and Administration of Ukraine], f. P-2, d. 13, c. 5088, pp. 72-75. (in Ukrainian).

36. Shajtan, B. I., \& Polishhuk, P. N. (1960) Organizacija pticevodstva $v$ kolhoze "Kolos" [The organization of poultry farming at collective farm Kolos]. Pticevodstvo, no. 5, pp. 4-10. (in Russian).

\section{Information about the author:}

Victoriia Melnyk,

Candidate of Agricultural Sciences, Associate Professor,

National University of Life and Environmental Sciences of Ukraine 15, Heroyiv Oborony str., Kyiv, Ukraine ORCID ID: orcid.org/0000-0003-2491-757X 


\section{EVOLUTION OF THE SCIENTIFIC-ORGANIZATIONAL FOUNDATIONS OF ORGANIC FARMING IN UKRAINE: HISTORIOGRAPHY OF THE INDEPENDENCE PERIOD}

\section{Volodymyr Orekhivskyi}

\section{INTRODUCTION}

The historiography of the evolution of the scientific-organizational foundations of organic farming has a long tradition. Due to the development of thinking and the latest scientific approaches, historical works on the problem of research are divided in chronological principle into two groups. The first of these includes scientific publications published in the Soviet era, and the second - during the independence of Ukraine ${ }^{1}$. They differ in principled approaches, ideological content, provisions and conclusions, since researchers of the history of agrarian science worked in different socio-economic and socio-political conditions of certain historical periods. An independent period in historiography began in independent Ukraine in search of new conceptual approaches to the historical knowledge of world and regional alternative measures ${ }^{2}$. Historiography has begun to play the role of an integration factor, maintaining an appropriate level of knowledge regarding the development of environmentally friendly technologies in Ukraine ${ }^{3}$.

\footnotetext{
1 Orekhivskyi, V. D. (2017) Evoliutsiia naukovykh osnov orhanichnoho zemlerobstva $v$ Ukraini (druha polovyna XIX - pochatok XXI st.): monohrafiia [Evolution of the scientific basis of organic agriculture in Ukraine (the second half of XIX is beginning of XXI of century): monograph]. Vinnytsia: TOV «Nilan-LTD», p. 12. (in Ukrainian).

2 Kovalenko, N. P. (2014) Stanovlennia ta rozvytok naukovo-orhanizatsiinykh osnov zastosuvannia vitchyznianykh sivozmin u systemakh zemlerobstva (druha polovyna XIX-pochatok XXI st.): monohrafiia [Becoming and development of scientifically-organizational bases of application of home crop rotations in the systems of agriculture (the second half of XIX is beginning of XXI of century): monograph]. Kyiv: TOV «Nilan-LTD», p. 17. (in Ukrainian).

Kovalenko, N. P. (2017) Zarodzhennia naukovykh osnov orhanichnoho zemlerobstva $v$ Ukraini $u$ XVIII - pershii polovyni XIX stolit [The emergence of the
} 
In modern domestic science, there has been an expansion of historical publications that reproduce the history of the formation and development of science and research in the field of organic agriculture of Ukraine. In particular, the evolution of particular scientific trends, theories, concepts and technologies in organic farming. Contribution to the development of scientific technologies of organic farming of higher education institutions, research institutions and research teams; the evolution of the scientific foundations of organic farming in the context of the activities of well-known agrarian scientists; development of practical introduction of organic farming in organic production enterprises in Ukraine ${ }^{4}$. They contain systematic factual material on the development of theoretical-methodological foundations and practical application of organic farming in Ukraine, a thorough analysis of scientific technologies and their theoretical generalizations.

To study the formation and development of organic farming in independent Ukraine, it was important to summarize the scientific achievements of researchers, identify conflicting, as well as insufficiently disclosed aspects that need further elaboration ${ }^{5}$. Therefore, the comprehensive coverage of historiography on the evolution of the scientific and organizational foundations of organic farming in the period of Ukraine's independence is of great importance. In particular, it is crucial to identify and analyze fundamental research on the history of the formation and development of theoretical, methodological and scientific-practical foundations of organic agriculture in different soil and climatic conditions of independent Ukraine.

scientific foundations of organic farming in Ukraine in the XVIII - first half of the XIX centuries]. Visnyk ahrarnoi istorii, vol. 19-20, p. 201. (in Ukrainian).

4 Orekhivskyi, V. D. (2017) Evoliutsiia naukovykh osnov orhanichnoho zemlerobstva $v$ Ukraini (druha polovyna XIX - pochatok XXI st.): monohrafiia [Evolution of the scientific basis of organic agriculture in Ukraine (the second half of XIX is beginning of XXI of century): monograph]. Vinnytsia: TOV «Nilan-LTD», p. 13. (in Ukrainian).

${ }^{5}$ Kovalenko, N. P. (2017) Evoliutsiia naukovykh osnov orhanichnoho zemlerobstva $v$ Ukraini $u$ druhii polovyni XIX - na pochatku XXI stolit [The evolution of the scientific foundations of organic farming in Ukraine in the second half of the XIX - at the beginning XXI centuries]. Visnyk ahrarnoi istorii, vol.21-22, p. 259. (in Ukrainian). 


\section{The formation of theoretical-methodological foundations of organic farming in the historiography of independent Ukraine}

One of the first publications of agrarian directions on improvement of ecologically safe measures in organic farming were the works of P. I. Boyko, N. P. Kovalenko, which describes the evolution of theoretical aspects of biological biology of agriculture from ancient times. They analyzed the history, current state and prospects of the development of farming systems and crop rotation ${ }^{6}$, identified the historical and modern achievements of their research and implementation $^{7}$, determined the effectiveness of steam use in the past and present agriculture of Ukraine ${ }^{8}$. They reveal the history of formation and development of one of the basic links of organic farming - scientifically based crop rotations. The gradual improvement of alternation of crops with different biological properties and agrotechnics - cereals, technical, fodder, vegetables, as well as steam, the use of effective precursors and permissible periods of return to the previous place of cultivation was analyzed ${ }^{9}$.

It should be noted that a comprehensive historical study of N. P. Kovalenko on the formation and development of scientific and organizational foundations of the use of one of the main links of organic farming - scientifically substantiated crop rotations in the systems of agriculture during the second half of the $19^{\text {th }}$ and early $21^{\text {st }}$

6 Boiko, P. I. \& Kovalenko, N. P. (2004) Systemy zemlerobstva ta sivozminy: istoriia, suchasnyi stan $i$ perspektyvy rozvytku [Systems of agriculture and crop rotation: history, current state and prospects for development]. Visnyk Poltavskoi derzhavnoi ahrarnoi akademii, vol. 3, pp. 21-26. (in Ukrainian).

7 Boiko, P. I. \& Kovalenko, N. P. (2005) Istorychni $i$ suchasni dosiahnennia $u$ vyvchenni ta vprovadzhenni system zemlerobstva $i$ sivozmin [Historical and contemporary achievements in the study and implementation of farming systems and crop rotations]. Ahronom, no. 3, pp. 78-81. (in Ukrainian).

8 Boiko, P. I. \& Kovalenko, N. P. (2008) Pary $v$ proshlom y sovremennom zemledelyy [Pairs in past and present agriculture]. Ahrovisnyk Ukraina. no. 2. pp. 14-17. (in Russia).

9 Orekhivskyi, V. D. (2017) Evoliutsiia naukovykh osnov orhanichnoho zemlerobstva $v$ Ukraini (druha polovyna XIX - pochatok XXI st.): monohrafiia [Evolution of the scientific basis of organic agriculture in Ukraine (the second half of XIX is beginning of XXI of century): monograph]. Vinnytsia: TOV «Nilan-LTD», p. 313. (in Ukrainian). 
centuries $^{10}$. The researcher, based on historical-scientific analysis, reproduced the evolution of crop rotation and other ecologically safe agrotechnical measures in the agriculture of Ukraine, suggested the periodization of their formation and development, determined the contribution of higher education institutions, research institutions, theorists and practitioners in this process. Considerable attention was paid to the formation and development of scientific schools for the improvement of ecologically safe agrotechnical measures in agriculture of different soil and climatic conditions of Ukraine ${ }^{11}$.

The evolution of organic farming in Ukraine is of great importance in the publications of N. P. Kovalenko, where the subject of research was the scientific-organizational and conceptual foundations of the development of ecologically balanced crop rotation in systems of alternative agriculture $^{12}$. In addition, the researcher analyzed the origin of scientific foundations of organic farming in Ukraine in the $18^{\text {th }}$ - first half of the $19^{\text {th }}$ century ${ }^{13}$, their evolutionary changes in the second half of the $19^{\text {th }}$ and early $21^{\text {st }}$ centuries $^{14}$. In particular, the efficiency of growing

10 Kovalenko, N. P. (2014) Stanovlennia ta rozvytok naukovo-orhanizatsiinykh osnov zastosuvannia vitchyznianykh sivozmin u systemakh zemlerobstva (druha polovyna XIX-pochatok XXI st.): monohrafiia [Becoming and development of scientifically-organizational bases of application of home crop rotations in the systems of agriculture (the second half of XIX is beginning of XXI of century): monograph]. Kyiv: TOV «Nilan-LTD», 490 s. (in Ukrainian).

Orekhivskyi, V. D. (2017) Evoliutsiia naukovykh osnov orhanichnoho zemlerobstva $v$ Ukraini (druha polovyna XIX - pochatok XXI st.): monohrafiia [Evolution of the scientific basis of organic agriculture in Ukraine (the second half of XIX is beginning of XXI of century): monograph]. Vinnytsia: TOV «Nilan-LTD», p. 19. (in Ukrainian).

12 Kovalenko, N.P. (2012) Ekolohichno zbalansovani sivozminy $v$ systemi alternatyvnoho zemlerobstva: istorychni aspekty [Ecologically balanced crop rotation in the system of alternative agriculture: historical aspects]. Ahroekolohichnyi zhurnal, no. 4, pp. 95-99. (in Ukrainian).

13 Kovalenko, N. P. (2017) Zarodzhennia naukovykh osnov orhanichnoho zemlerobstva $v$ Ukraini $u$ XVIII - pershii polovyni XIX stolit [The emergence of the scientific foundations of organic farming in Ukraine in the XVIII - first half of the XIX centuries]. Visnyk ahrarnoi istorii, vol. 19-20, pp. 200-216. (in Ukrainian).

14 Kovalenko, N. P. (2017) Evoliutsiia naukovykh osnov orhanichnoho zemlerobstva $v$ Ukraini $u$ druhii polovyni XIX - na pochatku XXI stolit [The evolution of the scientific foundations of organic farming in Ukraine in the second half of the XIX - at the beginning XXI centuries]. Visnyk ahrarnoi istorii, vol. 21-22, pp. 258-268. (in Ukrainian). 
leguminous and sidereal crops in crop rotation, grassland, the use of postharvest and post-cultivation crops, by-products, the use of organic fertilizers and rational cultivation of soil ${ }^{15}$. In the scientific works of N. P. Kovalenko the historical aspects of the origin and development of scientific and organizational foundations of different types of crop rotations - sidereal $^{16}$, grassland ${ }^{17}$, the evolution of scientific views on allelopathic activity of crops in crop rotation ${ }^{18}$ are analyzed.

Noteworthy are the scientific publications devoted to the evolution of theoretical-methodological foundations of different directions of greening agriculture in Ukraine and in the world dimension. In particular, M. Ya. Bomba, H. T. Pyrog, S. M. Ryzhuk agriculture with the basics of soil science, agrochemistry and $\operatorname{agroecology}^{19}$; G. I. Demidas, I. D. Primak, V. G. Roshko - rational crop rotation in modern agriculture ${ }^{20}$; V. P. Gudz, I. D. Primak, M. F. Rybak - adaptive systems of farming ${ }^{21}$. In them the history of

15 Orekhivskyi, V. D. (2018) Rozvytok zastosuvannia travosiiannia i travopilnykh sivozmin $v$ orhanichnomu zemlerobstvi URSR u pershii polovyni XX stolittia [Development of the use of herbivores and herbivory crop rotations in the organic agriculture of the USSR in the first half of the XX century]. Istoriia nauky i tekhniky, vol. 8. p. 159. (in Ukrainian).

${ }^{16}$ Kovalenko, N. P. (2012) Istorychni aspekty zarodzhennia i rozvytku naukovykh znan pro syderalni sivozminy [Historical aspects of the origin and development of scientific knowledge about sidereal rotations]. Silskyi hospodar, no. 11-12, pp. 27-33. (in Ukrainian).

${ }^{17}$ Kovalenko, N. P. (2009) Istoriia zarodzhennia i rozvytku naukovykh znan pro travopilni sivozminy [History of the origin and development of scientific knowledge about herbivore rotations]. Istoriia nauky i biohrafistyka (electronic journal), no. 2. Retrieved from: http://inb.dnsgb.com.ua/2009-2/09_kovalenko.pdf (accessed 30 May 2019). (in Ukrainian).

${ }^{18}$ Kovalenko, N. P. (2012) Evoliutsiia naukovykh pohliadiv shchodo alelopatychnoi aktyvnosti silskohospodarskykh kultur u sivozminakh [Evolution of scientific views on allelopathic activity of crops in crop rotation]. Silskohospodarska mikrobiolohiia, vol. 15-16, pp. 161-173. (in Ukrainian).

${ }^{19}$ Bomba, M. Ya., Perih, H. T. \& Ryzhuk, S. M. (2003) Zemlerobstvo z osnovamy gruntoznavstva, ahrokhimii ta ahroekolohii [Agriculture with the basics of soil science, agrochemistry and agroecology]. Kyiv: Urozhai, 400 s. (in Ukrainian).

${ }^{20}$ Prymak, I. D., Roshko, V. I. \& Demydas, I. I. (2003) Ratsionalni sivozminy $v$ suchasnomu zemlerobstvi [Rational crop rotation in modern agriculture]. Bila Tserkva: BDAU, 384 s. (in Ukrainian).

21 Gudz, V. P., Prymak, I. D. \& Rybak, M. F. (2007) Adaptyvni systemy zemlerobstva [Adaptive farming systems]. Kyiv: Tsentr uchbovoi literatury, $336 \mathrm{~s}$. (in Ukrainian). 
formation and development of theoretical-methodological foundations of ecologically safe measures in agriculture on the drained, irrigated and eroded lands is fragmented, but no attention is paid to the researches of Ukrainian scientists ${ }^{22}$.

Valuable scientific publication is V.A. Vergunov, I. D. Primak, V. G. Roshko, which reflects the history of formation and development of scientific bases of agricultural systems, reproduces the evolution of theoretical-methodological aspects of biological of agriculture from ancient times $^{23}$. Scientific works are devoted to the elucidation and solution of problems of ecologization of agriculture in Ukraine: S. V. Begey, I. A. Shuvar ${ }^{24}$, V.P. Gudz, M. F. Rybak, M. M. Tymoshenko ${ }^{25}$, Yu. P. Manko, I. D. Primak, N. M. Reidey ${ }^{26}$. They give a history of the formation and development of the theoretical-methodological foundations of organic farming, but do not trace their relationship with other systems.

Important are the scientific publications dedicated to the development of ecologically sound scientific activities in organic agriculture in Ukraine. In particular, the monographs of O. M. Bunchak, V. M. Sendetsky, I. A. Shuvar ${ }^{27}$, M. K. Linnyk, M. M. Symchuk ${ }^{28}$ explain the history of production and use of organic

22 Orekhivskyi, V. D. (2017) Evoliutsiia naukovykh osnov orhanichnoho zemlerobstva $v$ Ukraini (druha polovyna XIX - pochatok XXI st.): monohrafiia [Evolution of the scientific basis of organic agriculture in Ukraine (the second half of XIX is beginning of XXI of century): monograph]. Vinnytsia: TOV «Nilan-LTD», p. 21. (in Ukrainian).

${ }^{23}$ Prymak, I. D., Verhunov, V. A. \& Roshko, V. H. (2004) Systemy zemlerobstva: istoriia yikh rozvytku $i$ naukovi osnovy [Systems of agriculture: history of their development and scientific basis]. Bila Tserkva: BDAU, 528 s. (in Ukrainian).

${ }^{24}$ Behei, S. V. \& Shuvar, I. A. (2007) Ekolohichne zemlerobstvo [Organic farming]. Lviv: Novyi svit - 2000, 432 s. (in Ukrainian).

${ }^{25}$ Gudz, V.P., Rybak, M.F. \& Tymoshenko, M. M. (2012) Ekolohichni problemy zemlerobstva [Environmental problems of agriculture]. Zhytomyr, $560 \mathrm{~s}$. (in Ukrainian).

26 Prymak, I. D., Manko, Yu. P. \& Ridei, N. M. (2010) Ekolohichni problemy zemlerobstva [Environmental problems of agriculture]. Kyiv: Tsentr uchbovoi literatury, $456 \mathrm{~s}$. (in Ukrainian).

27 Shuvar, I. A., Sendetskyi, V. M. \& Bunchak, O. M. (2015) Vyrobnytstvo ta vykorystannia orhanichnykh dobryv: monohrafiia [Production and use of organic fertilizers: monograph]. Ivano-Frankivsk: Symfoniia forte, 596 s. (in Ukrainian).

28 Linnyk, M. K. \& Symchuk, M. M. (2012) Tekhnolohii i tekhnichni zasoby vyrobnytstva ta vykorystannia orhanichnykh dobryv [Technologies and technical means of production and use of organic fertilizers]. Hlevakha, 248 s. (in Ukrainian). 
fertilizers. The researchers analyzed the formation, development and current state of production and use of traditional organic fertilizers; vermiculture biohumus; microorganisms derived from organic waste from poultry farms, livestock complexes, leather production by aerobic biological fermentation, microbial associations by composting, liquid fertilizer biostimulators by cavitation, straw destruction and sideration. Researchers have developed and implemented in the production of vermiculture technology and biological accelerated fermentation taking into account the climatic and economic conditions of Ukraine in the agricultural enterprises of Vinnitsa, Volyn, Ivano-Frankivsk, Kyiv, Lviv, Khmelnytsky and other regions of Ukraine ${ }^{29}$. Scientific technology of destroying straw and other plant residues by VermistimD destructor in conjunction with sowing of sidereal crops was developed and introduced in agricultural enterprises of the mentioned regions of Ukraine. Researchers have found that expanding the use of ecologically friendly organic fertilizers - straw and green fertilizers - is one of the most important elements of organic farming that increases soil fertility and improves the ecological status of agroecosystems.

The monographs of N. M. Kolisnyk, I. P. Melnyk, I. A. Shuvar ${ }^{30}$, V. O. Andrienko, I. A. Melnyk, M. F. Povkhan ${ }^{31}$ provide important information on the historical aspects of formation and the development of theoretical-methodological foundations for the cultivation and practical application of earthworms in agricultural enterprises of Ukraine. Scientists have clarified the importance of the results of many years of research by Ukrainian and foreign scientists on improving the theoretical-methodological foundations of technologies for the production of biohumus from organic waste by the method of

29 Orekhivskyi, V. D. (2018) Tendentsii rozvytku vermykultury - odnoho $z$ osnovnykh napriamiv orhanichnoho zemlerobstva $v$ Ukraini [Trends in vermiculture one of the main areas of organic farming in Ukraine]. Eminak, no. 21, p. 154. (in Ukrainian).

${ }^{30}$ Melnyk, I. P., Kolisnyk, N. M. \& Shuvar, I. A. (2015) Doshchovi cherviaky: naukovi aspekty vyroshchuvannia $i$ praktychne zastosuvannia: monohrafiia [Earthworms: scientific aspects of growing and practical application: monograph]. Ivano-Frankivsk: Symfoniia forte, $444 \mathrm{~s}$. (in Ukrainian).

31 Povkhan, M. F., Melnyk, I. A. \& Andryenko, V. A. (1994) Vermykultura: proyzvodstvo y yspolzovanye [Vermiculture: production and use]. Kyev: UkrNYYYTEY, 128 s. (in Russia). 
vermiculture, development and use of complex humic preparations from vermiculose compost. The researchers analyzed the development of industrial vermiculture technologies on various types of organic waste and biohumus production: technology of obtaining organicmineral fertilizers based on biohumus, utilization of organic waste with the help of heterotrophic organisms, processing of organic waste by higher edible biobodies ${ }^{32}$. The ways of improving the initial uterine populations and their adaptation to various organic substrates, and obtaining biologically active preparations from the tissues of the vermicultural organism are determined.

Valuable information is contained in scientific publications dedicated to the evolution of scientific-organizational foundations of different soil tillage systems to reproduce soil fertility. In particular, in the monograph V. O. Andrienko, S. S. Antonets, M. K. Shikula the role of perfection of surface ashless cultivation in improvement of soil properties, biochemical mechanism of humus restoration and fertility self-regulation, carbon dioxide assimilation and soil humidity is given. The coefficients of humification of manure and plant residues are specified, the management of soil formation in agrocenoses of Ukraine during the $1970^{\mathrm{s}}-1990^{\mathrm{s}}$ is analyzed in detail ${ }^{33}$. The results of researches of scientists in the long-term multifactorial experiments of the National Agrarian University on improving the efficiency of soil protection technologies in different soil and climatic conditions of Ukraine are presented.

Noteworthy are the publications of V.O. Yeshchenko, Yu. P. Manko, I. D. Primak ${ }^{34}$, F. T. Morgun ${ }^{35}$, devoted to the

32 Orekhivskyi, V. D. (2018) Tendentsii rozvytku vermykultury - odnoho $z$ osnovnykh napriamiv orhanichnoho zemlerobstva v Ukraini [Trends in vermiculture one of the main areas of organic farming in Ukraine]. Eminak, no. 21, p. 153. (in Ukrainian).

33 Shykula, M. K., Antonets, S. S. \& Andriienko, V. O. (1998) Vidtvorennia rodiuchosti gruntiv u gruntozakhysnomu zemlerobstvi: naukova monohrafiia [Soil fertility reproduction in soil protection agriculture: scientific monograph]. Kyiv: Oranta, 680 s. (in Ukrainian).

${ }^{34}$ Prymak, I. D., Yeshchenko, V. O. \& Manko, Yu. P. (2007) Resursozberihaiuchi tekhnolohii mekhanichnoho obrobitku gruntu $v$ suchasnomu zemlerobstvi Ukrainy [Resource-saving technologies of mechanical tillage in modern agriculture of Ukraine]. Kyiv : KVITs, 272 s. (in Ukrainian). 
elucidation of the process of improving the theoretical-methodological foundations of resource-saving technologies of soil cultivation in soil protection agriculture of Ukraine. According to the results of many years of research, the systematic application on the slopes of soil protective technologies of cultivation of crops contributed to the formation of agrophysical indicators of the treated soil layer, which reduced the manifestations of erosion: increased water permeability, structural and water resistance of aggregates ${ }^{36}$.

In the monograph by M. P. Kosolap, O. P. Krotinov, the history of the development of the scientific bases of agricultural systems is analyzed, in particular, the features of the propagation of technologies of cultivation of crops for the systems of agriculture "No-till", N. P. Kovalenko's publications, the evolution of the use of soil tillage tools has been elucidated since ancient times ${ }^{38}$. The researcher established the basic laws and tendencies of the use of the soil tillage system by the method of T.S. Maltsev in the Ukraine in the $1950^{\mathrm{s}}$. Defined cultivation of soil in crops of different crops of the Steppe, Forest-steppe and Polesie of the Ukraine ${ }^{39}$.

The history of the development of the scientific foundations of biological measures of plant protection against diseases and pests is covered in the publications of V.P. Vasylyev, M. P. Lisovyi ${ }^{40}$,

35 Morhun, F. T. (2008). Vybir Ukrainy - poriatunok pryrody i sela [Ukraine's choice is to save nature and the countryside]. Poltava: Dyvosvit. 236 s. (in Ukrainian).

${ }^{36}$ Orekhivskyi, V. D. (2017) Evoliutsiia naukovykh osnov zastosuvannia obrobitku gruntu v orhanichnomu zemlerobstvi Ukrainy (druha polovyna XIX - pochatok XXI st.) [Evolution of scientific bases of application of soil cultivation in organic agriculture of Ukraine (second half of XIX - beginning of XXI century)]. Visnyk ahrarnoi istorii, vol. 19-20. p. 221. (in Ukrainian).

37 Kosolap, M. P. \& Krotinov, O. P. (2011) Systema zemlerobstva No-Till [The system farming No-Till]. Kyiv: Lohos, 352 s. (in Ukrainian).

38 Kovalenko, N. P. (2016) Evoliutsiia vykorystannia znariad obrobitku gruntu u vitchyznianomu zemlerobstvi [Evolution of the use of soil tillage tools in domestic agriculture]. History of science and technique, vol. 8, pp. 129-139. (in Ukrainian).

${ }^{39}$ Kovalenko, N. P. (2018) Evoliutsiia zastosuvannia systemy obrobitku gruntu za metodom T. S. Maltseva v URSR u 1954-1955 rokakh [Evolution of the application of the soil tillage system by the method of T. S. Maltsev in the Ukraine in 1954-1955]. Istoriia nauky i tekhniky, vol. 11. pp. 175-186. (in Ukrainian).

${ }^{40}$ Vasylev, V. P. \& Lesovoi, M. P. (1996) Ystoryia zashchyty rastenyi ot vredytelei $y$ boleznei $v$ Ukrayne [The history of plant protection from pests and diseases in Ukraine]. Kyev: Ahrarna nauka, 132 s. (in Russia). 
V. P. Konverska, O. M. Tkalenko, V. P. Fedorenko ${ }^{41}$. The ecological basis for the reduction of agrophytocenosis weediness is in I. A. Shuvar's monograph ${ }^{42}$. These publications provide a history of developing the scientific-theoretical foundations of ecologically safe control of agrophytocenosis weeds and the reduction of disease and pests. Researchers have discovered the wide organizational possibilities of using agrotechnical and biological methods to attenuate the phytotoxic action of residues of agrochemicals, depending on soil and climatic conditions, biochemical characteristics of plants and physicochemical properties of herbicides.

Of great importance are the scientific publications dedicated to the evolution of the scientific and organizational foundations of soil erosion protection measures. In the monograph of M. D. Voloshchuk, N. I. Petrenko, S. V. Yatsenko the classical essence of soil erosion is revealed on the basis of historical and recent sources and the consequences of influence on the earth's surface of water, wind and anthropogenic factors are determined ${ }^{43}$. Scientists have substantiated the need to further improve the theoretical-methodological foundations of erosion science in order to accelerate the introduction of soil protection measures in the production. The history of formation and development of scientific centers of erosion science in different soil and climatic conditions of Ukraine is given; the current state and prospects of the development of theoretical-methodological foundations of soil protection against erosion are highlighted ${ }^{44}$.

${ }^{41}$ Fedorenko, V. P., Tkalenko, A. N. \& Konverskaia, V. P. (2010) Dostyzhenyia y perspektyvy razvytyia byolohycheskoho metoda zashchyty rastenyi $v$ Ukrayne [Achievements and development prospects of the biological method of plant protection in Ukraine]. Zashchyta y karantyn rastenyi, no. 4, pp. 12-15. (in Russia).

42 Shuvar, I. A. (2008) Ekolohichni osnovy znyzhennia zaburianenosti ahrofitotsenoziv [Environmental basics of agrophytocenosis weed reduction]. Lviv: Novyi Svit - 2000, 496 s. (in Ukrainian).

43 Voloshchuk, M. D., Petrenko, N. I. \& Yatsenko, S. V. (2014) Eroziia gruntiv Ukrainy: evoliutsiia teorii i praktyky: monohrafiia [Soil erosion of Ukraine: evolution of theory and practice: monograph]. Kyiv: TOV «Nilan-LTD», $326 \mathrm{~s}$. (in Ukrainian).

44 Orekhivskyi, V. D. (2017) Evoliutsiia naukovykh osnov orhanichnoho zemlerobstva $v$ Ukraini (druha polovyna XIX - pochatok XXI st.): monohrafiia [Evolution of the scientific basis of organic agriculture in Ukraine (the second half of XIX is beginning of XXI of century): monograph]. Vinnytsia: TOV «Nilan-LTD», p. 133. (in Ukrainian). 
In the publication of N. P. Kovalenko, the evolution of the development of economic-mathematical methods for the optimization of soil-protective crop rotations in the second half of the $20^{\text {th }}-$ the beginning of the $21^{\text {st }}$ century is widely analyzed ${ }^{45}$. The researcher found that the optimization of soil protection crop rotation was based on the rational use of land potential of the state and restoration of ecological equilibrium of agricultural landscapes, organization of land use and solving the problem of environmental protection ${ }^{46}$. It carried out the classification and generalization of environmental criteria, which improved and expanded the dimension of economicmathematical models.

Of great importance is the monograph of the team of scientists of the National Scientific Center "Institute of Agriculture of the NAAS", edited by Ya. M. Hadzalo, which is devoted to a fundamental study of the history of the development of theoretical-methodological foundations of organic production in various soil and climatic conditions of Ukraine ${ }^{47}$. In particular, scientists have determined the prerequisites for the emergence of organic movement, the soil and climatic signs of organic agriculture in Ukraine, the features of production, regulatory and legal support, the formation and functioning of the organic produce market in Ukraine ${ }^{48}$.

45 Kovalenko, N. P. (2011) Istoriia optymizatsii gruntozakhysnykh sivozmin na osnovi ekonomiko-matematychnoho modeliuvannia druhoi polovyny XX - XXI stolittia [History of optimization of soil-protective crop rotations on the basis of economic and mathematical modeling of the second half of the XX - XXI centuries]. Istoriia nauky $i$ biohrafistyka (electronic journal), no. 1. Retrieved from: http://www.inb.dnsgb.com.ua/ 2011-1/11_kovalenko.pdf (accessed 30 May 2019). (in Ukrainian).

46 Orekhivskyi, V. D. (2017) Evoliutsiia naukovykh osnov orhanichnoho zemlerobstva $v$ Ukraini (druha polovyna XIX - pochatok XXI st.): monohrafiia [Evolution of the scientific basis of organic agriculture in Ukraine (the second half of XIX is beginning of XXI of century): monograph]. Vinnytsia: TOV «Nilan-LTD», p. 146. (in Ukrainian).

47 Hadzalo, Ya. M. (ed.) (2016) Naukovi osnovy vyrobnytstva orhanichnoi produktsii v Ukraini: monohrafiia [Scientific bases of organic production in Ukraine: monograph]. Kyiv: Ahrarna nauka, 592 s. (in Ukrainian).

${ }^{48}$ Orekhivskyi, V. D. (2017) Evoliutsiia naukovykh osnov orhanichnoho zemlerobstva $v$ Ukraini (druha polovyna XIX - pochatok XXI st.): monohrafiia [Evolution of the scientific basis of organic agriculture in Ukraine (the second half of XIX 


\section{Development of scientific-practical foundations of organic farming in Ukraine in epy historiography of the independence period}

One of the first fundamental works of economic direction to improve the process of organic production was the monograph M. M. Fedorov, O. V. Khodakivska， S. G. Korchinska ${ }^{49}$. The researchers analyzed the history of the development of scientific-practical foundations of world and domestic production of organic products, the formation of regulatory framework, features of market development, standardization and certification of organic products. Scientists have conditionally identified three main stages of the transition of the Private enterprise "Agroecology" of Poltava region to organic production. The first dates back to 1976, when the collective farm named Ordzhonikidze became the basic farm for the production testing of the use of soil-protective agriculture ${ }^{50}$. The second stage began in 1979, a feature of which was the introduction into the management of soil biological technologies, the basis of which was the complete rejection of pesticides in the fields. The third stage, characterized as the development of organic farming, began in 1986, when synthetic mineral fertilizers were replaced on the farm by the use of organic fertilizers and siderates.

The monograph of V. V. Pindus, V. V. Rekunenko, P. A. Stetsyshyn describes the evolution of scientific-practical foundations of organic production, the introduction of innovative technologies for growing and harvesting field, vegetable and fruit crops in organic agriculture $^{51}$. Scientists have scientifically substantiated the

is beginning of XXI of century): monograph]. Vinnytsia: TOV «Nilan-LTD», p. 215. (in Ukrainian).

49 Fedorov, M. M., Khodakivska, O. V. \& Korchynska, S. H. (2011) Rozvytok orhanichnoho vyrobnytstva [Development of organic production]. Kyiv: NNTs IAE, 146 s. (in Ukrainian).

50 Orekhivskyi, V. D. (2018) Evoliutsiia vprovadzhennia systemy orhanichnoho zemlerobstva v Pryvatnomu Pidpryiemstvi «Ahroekolohiia» $u$ druhii polovyni XX - na pochatku XXI stolit [Evolution of the organic farming system implementation in PE «Agroecology» in the second half of XX - at the beginning XXI of centuries]. Hileia, vol. 130, p. 116. (in Ukrainian).

51 Stetsyshyn, P. O., Pyndus, V. V. \& Rekunenko, V. V. (2011) Osnovy orhanichnoho vyrobnytstva [Fundamentals of organic production]. Vinnytsia: Nova knyha, 552 s. (in Ukrainian). 
development of organic, biodynamic systems of agriculture and technologies of effective microorganisms, advanced methods of using microbiological preparations for the control of pests and diseases of crops, as well as a system of machines for organic production. Researchers have analyzed the development of practical production of organic crop and livestock production at enterprises in different soil and climatic conditions of Ukraine in the early $21^{\text {st }}$ century.

Further development of research was covered in the monograph T. G. Dudar, O. T. Dudar, which clarified the scientific-organizational principles of the formation and development of organic farming. Systematic analysis and evaluation of the practical management of organic farming in agrarian enterprises, provided conceptual organizational-economic principles of the strategy of formation and development of organic production in the context of ecologization the agrosphere ${ }^{52}$. The researchers found that during the 1990-2000', Ukraine, with significant potential for organic production, export, consumption on the domestic market, achieved certain results in developing its own organic production. Scientists have identified significant growth in Ukraine at the beginning of the $21^{\text {th }}$ century certified organic farms for organic production ${ }^{53}$. They determined that, given the significant regional features of the agrarian sector of Ukraine, certified organic farms that produced organic crop products, overwhelmingly specialized in growing winter wheat, spring barley, rye, oats, buckwheat, sunflower, soybean, soybean, supplementary crops.

From the standpoint of the systematic approach in the T. A. Chaika monograph, the scientific and organizational aspects of organic production as a strategic direction for the development of the agrarian sector of the Ukraine economy have been investigated ${ }^{54}$. In the opinion

52 Dudar, T. H. \& Dudar, O. T. (2012) Stratehiia formuvannia systemy orhanichnoho ahrarnoho vyrobnytstva: monohrafiia [The strategy of forming a system of organic agricultural production: monograph]. Ternopil: Aston, 292 s. (in Ukrainian).

53 Orekhivskyi, V. D. (2017) Evoliutsiia naukovykh osnov orhanichnoho zemlerobstva $v$ Ukraini (druha polovyna XIX - pochatok XXI st.): monohrafiia [Evolution of the scientific basis of organic agriculture in Ukraine (the second half of XIX is beginning of XXI of century): monograph]. Vinnytsia: TOV «Nilan-LTD», p. 27. (in Ukrainian).

${ }^{54}$ Chaika, T. O. (2013) Rozvytok vyrobnytstva orhanichnoi produktsii v ahrarnomu sektori ekonomiky Ukrainy: monohrafiia [Development of organic production in the agricultural sector of the Ukrainian economy: monograph]. Donetsk: Noulidzh, 320 s. (in Ukrainian). 
of the researcher it was important to find out the essence of the formation and development of organic production in agricultural enterprises of Ukraine with the need to evaluate their effectiveness. The scientist analyzed the development of scientific-practical bases of application of organic technologies in certified organic enterprises of Ukraine at the beginning of the $21^{\text {st }}$ century. In particular, the company "EthnoProduct" of Chernihiv region, which produced organic products, focusing on domestic and foreign markets. It has been found that over the years of its development, the enterprise has become one of the powerful producers of organic cereals, legumes, oil and vegetables, meat, milk and honey in Ukraine ${ }^{55}$. The scientist found that organic products on the farm were grown without genetically modified organisms, hormones, growth promoters, pesticides and other agrochemicals in environmentally safe conditions. The activity of company "Living Planet Potutory" of Ternopil region was analyzed, which used biodynamic preparations, which was based on expanding the market of organic products and its assortment due to grain processing into cereals and flour. Efficiency of company "Old Porytsk" of the Volyn region, which due to introduction of modern technologies and strict control at all stages of production of organic production, has reached high indicators of quality of production. The activity of company "Organic Original" of Kyiv region, which specialized in the production of cold pressed sunflower oil, organic cereals, flour, honey, was determined effectively. The production of the company had a European organic certificate and is marked with the official logo of the European Union organics - "Eurolyst".

In the monograph by O. V. Khodakivska it is noted that organic agriculture is a component of greening of agrarian production ${ }^{56}$. The researcher reflects foreign experience of practical management of organic agriculture and features of its regulation, shows the

55 Orekhivskyi, V. D. (2018) Osoblyvosti rozvytku ahrarnykh pidpryiemstv z vyrobnytstva orhanichnoi produktsii v Ukraini (1990-ti - 2000-ni roky) [Features of development of agricultural enterprises for organic production in Ukraine $\left(1990^{\mathrm{S}}\right.$ $\left.2000^{\mathrm{S}}\right)$ ]. Hileia, vol. 133, p. 68. (in Ukrainian).

${ }^{56}$ Khodakivska, O. V. (2015) Ekolohizatsiia ahrarnoho vyrobnytstva: monohrafiia [Ecologization of agricultural production: monograph]. Kyiv: NNTs IAE, p. 159. (in Ukrainian). 
development of organic production in certified farms in Ukraine. The efficiency of scientific and practical bases of organic production in the Private enterprise "Agroecology" of Poltava region is analyzed ${ }^{57}$. Improvement of the efficiency of scientific technologies of organic production in the Private enterprise "Agroecology" due to their economic feasibility, ecological safety, energy and resource conservation, as well as social orientation is established.

Extensive information is contained in scientific publications on the development of organic production enterprises in Ukraine. In particular, the monographs of S. S. Antonets, A. S. Antonets, V. M. Pisarenko, P. V. Pisarenko about the experience of practical management ${ }^{58}$ and improvement of the system of organic farming in the Private enterprise "Agroecology" of Poltava region". Researchers have paid great attention to the history of the development of the use of environmentally friendly measures in organic farming, which were introduced in the economy during 1976-2017. The application of organic fertilizers, the cultivation of sidereal, post-harvest and postharvest crops, the use of environmentally friendly agrotechnical measures and microbiological preparations ${ }^{60}$. To compensate for the nutrients in the farm used organic fertilizers: manure, siderates, postharvest residues, which fully met the requirements of organic farming. Their introduction ensured the preservation and extended reproduction

57 Orekhivskyi, V. D. (2017) Evoliutsiia naukovykh osnov orhanichnoho zemlerobstva $v$ Ukraini (druha polovyna XIX - pochatok XXI st.): monohrafiia [Evolution of the scientific basis of organic agriculture in Ukraine (the second half of XIX is beginning of XXI of century): monograph]. Vinnytsia: TOV «Nilan-LTD», p. 336. (in Ukrainian).

58 Antonets, S. S., Antonets, A. S. \& Pysarenko, V. M. (2010) Orhanichne zemlerobstvo: z dosvidu PP «Ahroekolohiia» Shyshatskoho raionu Poltavskoi oblasti [Organic farming: from the experience of the PE «Agroecology» of Shishatsky district of Poltava region]. Poltava: RVV PDAA, 200 s. (in Ukrainian).

59 Pysarenko, V. M., Antonets, A. S. \& Pysarenko, P. V. (2017) Systema orhanichnoho zemlerobstva ahroekoloha Semena Antontsia [Organic farming system of agroecologist Semen Antonets]. Poltava: FOP Myron, I. A. 124 s. (in Ukrainian).

${ }^{60}$ Orekhivskyi, V. D. (2018) Evoliutsiia vprovadzhennia systemy orhanichnoho zemlerobstva v Pryvatnomu Pidpryiemstvi «Ahroekolohiia» u druhii polovyni XX - na pochatku XXI stolit [Evolution of the organic farming system implementation in PE «Agroecology» in the second half of XX - at the beginning XXI of centuries]. Hileia, vol. 130, p. 115. (in Ukrainian). 
of soil fertility and the production of ecologically friendly crop and livestock products.

Important is the information of O. M. Yushchenko on the development of organic production in the Zhytomyr region ${ }^{61}$. It analyzed one of the largest organic farms in Ukraine - the Private Enterprise "Galeks-Agro", which implemented a model of a fullfledged ecological system, which combined organic crop production and organic animal husbandry. Important is the information on obtaining the status of organic in 2009 with the certification of organic production $^{62}$.

In the scientific publication V. M. Pisarenko, P. V. Pisarenko, S. V. Ponomarenko the development of ecologically safe production for practical use in the private sector of Ukraine and measures to reduce the content of harmful substances in food at the beginning of the $21^{\text {st }}$ century are analyzed ${ }^{63}$. Researchers have characterized the features of cultivation technologies of field and vegetable crops in open and closed soil, the development of the use of plant infusions and decoctions for the control of leaf pests and diseases, as well as ecologically safe substances for plant protection ${ }^{64}$.

61 Yushchenko, O. M. (2017) Rozvytok orhanichnoho vyrobnytstva na Zhytomyrshchyni: dosvid PP «Haleks-Ahro» [Development of organic production in Zhytomyr region: experience of PE «Galex-Agro»]. Retrieved from: http://www.znau.edu.ua/media/nauka_innovation/organic/Organic_20132.pdf (accessed 30 May 2019). (in Ukrainian).

62 Orekhivskyi, V. D. (2018) Osoblyvosti rozvytku ahrarnykh pidpryiemstv z vyrobnytstva orhanichnoi produktsii v Ukraini (1990-ti - 2000-ni roky) [Features of development of agricultural enterprises for organic production in Ukraine $\left(1990^{\mathrm{s}}\right.$ $2000^{\mathrm{s}}$ )]. Hileia, vol. 133, p. 69. (in Ukrainian).

${ }^{63}$ Pysarenko, V. M., Pysarenko, P. V. \& Ponomarenko, S. V. (2017) Orhanichne zemlerobstvo dlya pryvatnoho sektora [Organic agriculture is for a private sector]. Poltava: FOP Myron, I. A., 140 s. (in Ukrainian).

${ }^{64}$ Orekhivskyi, V. D. (2018) Evoliutsiia vprovadzhennia systemy orhanichnoho zemlerobstva v Pryvatnomu Pidpryiemstvi «Ahroekolohiia» $u$ druhii polovyni XX - na pochatku XXI stolit [Evolution of the organic farming system implementation in PE «Agroecology» in the second half of XX - at the beginning XXI of centuries]. Hileia, vol. 130, p. 117. (in Ukrainian). 


\section{CONCLUSION}

It can be concluded that the historiography on the evolution of the scientific-organizational foundations of organic farming in the period of Ukraine's independence is multifaceted both in terms of the generalizations presented and the level of study of the problems considered by scientists. In the historical scientific works the formation and development of separate scientific directions of organic farming in different soil and climatic conditions of Ukraine are defined. In particular, the application of theoretical-methodological aspects regarding scientifically grounded structure of sown areas and specialized crop rotations with perennial legumes, rational cultivation of soil, application of organic fertilizers, cultivation of sidereal crops, use of biohumus, mulching and microbiological preparations.

In the historiography of the period of independence of Ukraine the attention is paid to the history of development of scientific-practical bases of production of organic products at the enterprises, formation of the legal base, features of market development, standardization and certification of organic products. However, it was important not only their comprehensive and systematic research, but also the need to introduce into the circulation of unknown and unknown documentary sources, which ensured the restoration of a holistic process of evolution of scientific-organizational foundations of organic agriculture in independent Ukraine.

\section{SUMMARY}

The article provides an overview and analysis of basic research on the history of the formation and development of scientificorganizational foundations of organic agriculture in different soil and climatic conditions of independent Ukraine. By combining the principles of historicism and objectivity with the use of general scientific and special-historical methods: problem-chronological, comparative-historical, retrospective, source studies, a comprehensive scientific-historical analysis of the comprehensive and objective coverage of the development of scientific-organizational foundations of organic agriculture in independent Ukraine with the application of ecologically friendly measures and rational technologies of cultivation of crops. 
It is determined that the historiography of the period of independence of Ukraine on the evolution of scientific-organizational foundations of organic farming is multifaceted both in terms of the presented generalizations and in the level of study of problems considered by scientists. The value of historical works that reproduce the history of science and research in the field of organic farming in Ukraine has been clarified. In particular, the evolution of particular scientific directions, theories, concepts and scientific technologies in organic farming. Contribution to the development of scientific technologies of organic farming of higher education institutions, research institutions and research teams; the evolution of the scientific foundations of organic farming in the context of the activities of wellknown agrarian scientists; development of practical introduction of organic farming in organic production enterprises and the like.

The introduction into the scientific circulation of little-known and unknown documentary sources ensured the restoration of the holistic state of evolution of the scientific-organizational foundations of organic farming in independent Ukraine. It has been found that studies of Ukrainian historians of agrarian science have contributed to the objective and holistic reproduction of individual processes and patterns of evolution of the theoretical-methodological and scientific-practical foundations of organic agriculture, ensuring the application of historical methods and approaches.

\section{REFERENCES}

1. Antonets, S. S., Antonets, A. S. \& Pysarenko, V. M. (2010) Orhanichne zemlerobstvo: $z$ dosvidu PP "Ahroekolohiia" Shyshatskoho raionu Poltavskoi oblasti [Organic farming: from the experience of the PE "Agroecology" of Shishatsky district of Poltava region]. Poltava: RVV PDAA, 200 s. (in Ukrainian).

2. Behei, S. V. \& Shuvar, I. A. (2007) Ekolohichne zemlerobstvo [Organic farming]. Lviv: Novyi svit - 2000, 432 s. (in Ukrainian).

3. Boiko, P. I. \& Kovalenko, N. P. (2004) Systemy zemlerobstva ta sivozminy: istoriia, suchasnyi stan i perspektyvy rozvytku [Systems of agriculture and crop rotation: history, current state and prospects for development]. Visnyk Poltavskoi derzhavnoi ahrarnoi akademii, vol. 3, pp. 21-26. (in Ukrainian). 
4. Boiko, P. I. \& Kovalenko, N. P. (2005) Istorychni $i$ suchasni dosiahnennia $u$ vyvchenni ta vprovadzhenni system zemlerobstva $i$ sivozmin [Historical and contemporary achievements in the study and implementation of farming systems and crop rotations]. Ahronom, no. 3, pp. 78-81. (in Ukrainian).

5. Boiko, P. I. \& Kovalenko, N. P. (2008) Pary v proshlom y sovremennom zemledelyy [Pairs in past and present agriculture]. Ahrovisnyk Ukraina. no. 2. pp. 14-17. (in Russia).

6. Bomba, M. Ya., Perih, H. T. \& Ryzhuk, S. M. (2003) Zemlerobstvo $z$ osnovamy gruntoznavstva, ahrokhimii ta ahroekolohii [Agriculture with the basics of soil science, agrochemistry and agroecology]. Kyiv: Urozhai, 400 s. (in Ukrainian).

7. Chaika, T. O. (2013) Rozvytok vyrobnytstva orhanichnoi produktsii $v$ ahrarnomu sektori ekonomiky Ukrainy: monohrafiia [Development of organic production in the agricultural sector of the Ukrainian economy: monograph]. Donetsk: Noulidzh, 320 s. (in Ukrainian).

8. Dudar, T. H. \& Dudar, O. T. (2012) Stratehiia formuvannia systemy orhanichnoho ahrarnoho vyrobnytstva: monohrafiia [The strategy of forming a system of organic agricultural production: monograph]. Ternopil: Aston, 292 s. (in Ukrainian).

9. Fedorenko, V. P., Tkalenko, A. N. \& Konverskaia, V. P. (2010) Dostyzhenyia y perspektyvy razvytyia byolohycheskoho metoda zashchyty rastenyi $v$ Ukrayne [Achievements and development prospects of the biological method of plant protection in Ukraine]. Zashchyta y karantyn rastenyi, no. 4, pp. 12-15. (in Russia).

10. Fedorov, M. M., Khodakivska, O. V. \& Korchynska, S. H. (2011) Rozvytok orhanichnoho vyrobnytstva [Development of organic production]. Kyiv: NNTs IAE, 146 s. (in Ukrainian).

11. Gudz, V. P., Prymak, I. D. \& Rybak, M. F. (2007) Adaptyvni systemy zemlerobstva [Adaptive farming systems]. Kyiv: Tsentr uchbovoi literatury, $336 \mathrm{~s}$. (in Ukrainian).

12. Gudz, V. P., Rybak, M. F. \& Tymoshenko, M. M. (2012) Ekolohichni problemy zemlerobstva [Environmental problems of agriculture]. Zhytomyr, 560 s. (in Ukrainian).

13. Hadzalo, Ya. M. (ed.) (2016) Naukovi osnovy vyrobnytstva orhanichnoi produktsii $v$ Ukraini: monohrafiia [Scientific bases of 
organic production in Ukraine: monograph]. Kyiv: Ahrarna nauka, 592 s. (in Ukrainian).

14. Khodakivska, O. V. (2015) Ekolohizatsiia ahrarnoho vyrobnytstva: monohrafiia [Ecologization of agricultural production: monograph]. Kyiv: NNTs IAE, 350 s. (in Ukrainian).

15. Kovalenko, N. P. (2009) Istoriia zarodzhennia $i$ rozvytku naukovykh znan pro travopilni sivozminy [History of the origin and development of scientific knowledge about herbivore rotations]. Istoriia nauky $i$ biohrafistyka (electronic journal), no. 2. Retrieved from: http://inb.dnsgb.com.ua/2009-2/09_kovalenko.pdf (accessed 30 May 2019). (in Ukrainian).

16. Kovalenko, N. P. (2011) Istoriia optymizatsii gruntozakhysnykh sivozmin na osnovi ekonomiko-matematychnoho modeliuvannia druhoi polovyny XX - XXI stolittia [History of optimization of soil-protective crop rotations on the basis of economic and mathematical modeling of the second half of the XX XXI centuries]. Istoriia nauky $i$ biohrafistyka (electronic journal), no. 1. Retrieved from: http://www.inb.dnsgb.com.ua/20111/11_kovalenko.pdf (accessed 30 May 2019). (in Ukrainian).

17. Kovalenko, N. P. (2012) Ekolohichno zbalansovani sivozminy $v$ systemi alternatyvnoho zemlerobstva: istorychni aspekty [Ecologically balanced crop rotation in the system of alternative agriculture: historical aspects]. Ahroekolohichnyi zhurnal, no. 4, pp. 95-99. (in Ukrainian).

18. Kovalenko, N. P. (2012) Evoliutsiia naukovykh pohliadiv shchodo alelopatychnoi aktyvnosti silskohospodarskykh kultur $u$ sivozminakh [Evolution of scientific views on allelopathic activity of crops in crop rotation]. Silskohospodarska mikrobiolohiia, vol. 15-16, pp. 161-173. (in Ukrainian).

19. Kovalenko, N. P. (2012) Istorychni aspekty zarodzhennia $i$ rozvytku naukovykh znan pro syderalni sivozminy [Historical aspects of the origin and development of scientific knowledge about sidereal rotations]. Silskyi hospodar, no. 11-12, pp. 27-33. (in Ukrainian).

20. Kovalenko, N. P. (2014) Stanovlennia ta rozvytok naukovoorhanizatsiinykh osnov zastosuvannia vitchyznianykh sivozmin $u$ systemakh zemlerobstva (druha polovyna XIX - pochatok XXI st.): monohrafiia [Becoming and development of scientificallyorganizational bases of application of home crop rotations in the 
systems of agriculture (the second half of XIX is beginning of XXI of century): monograph]. Kyiv: TOV "Nilan-LTD”, 490 s. (in Ukrainian).

21. Kovalenko, N. P. (2016) Evoliutsiia vykorystannia znariad obrobitku gruntu $u$ vitchyznianomu zemlerobstvi [Evolution of the use of soil tillage tools in domestic agriculture]. History of science and technique, vol. 8, pp. 129-139. (in Ukrainian).

22. Kovalenko, N. P. (2017) Zarodzhennia naukovykh osnov orhanichnoho zemlerobstva $v$ Ukraini u XVIII - pershii polovyni XIX stolit [The emergence of the scientific foundations of organic farming in Ukraine in the XVIII - first half of the XIX centuries]. Visnyk ahrarnoi istorii, vol. 19-20, pp. 200-216. (in Ukrainian).

23. Kovalenko, N. P. (2017) Evoliutsiia naukovykh osnov orhanichnoho zemlerobstva $v$ Ukraini $u$ druhii polovyni XIX - na pochatku XXI stolit [The evolution of the scientific foundations of organic farming in Ukraine in the second half of the XIX - at the beginning XXI centuries]. Visnyk ahrarnoi istorii, vol.21-22, pp. 258-268. (in Ukrainian).

24. Kovalenko, N. P. (2018) Evoliutsiia zastosuvannia systemy obrobitku gruntu za metodom T. S. Maltseva v URSR u 1954-1955 rokakh [Evolution of the application of the soil tillage system by the method of T. S. Maltsev in the Ukraine in 1954-1955]. Istoriia nauky $i$ tekhniky, vol. 11. pp. 175-186. (in Ukrainian).

25. Kosolap, M. P. \& Krotinov, O. P. (2011) Systema zemlerobstva No-Till [The system farming No-Till]. Kyiv: Lohos, 352 s. (in Ukrainian).

26. Linnyk, M. K. \& Symchuk, M. M. (2012) Tekhnolohii $i$ tekhnichni zasoby vyrobnytstva ta vykorystannia orhanichnykh dobryv [Technologies and technical means of production and use of organic fertilizers]. Hlevakha, 248 s. (in Ukrainian).

27. Melnyk, I. P., Kolisnyk, N. M. \& Shuvar, I. A. (2015) Doshchovi cherviaky: naukovi aspekty vyroshchuvannia $i$ praktychne zastosuvannia: monohrafiia [Earthworms: scientific aspects of growing and practical application: monograph]. Ivano-Frankivsk: Symfoniia forte, $444 \mathrm{~s}$. (in Ukrainian).

28. Morhun, F. T. (2008). Vybir Ukrainy - poriatunok pryrody $i$ sela [Ukraine's choice is to save nature and the countryside]. Poltava: Dyvosvit. 236 s. (in Ukrainian). 
29. Orekhivskyi, V. D. (2017) Evoliutsiia naukovykh osnov orhanichnoho zemlerobstva v Ukraini (druha polovyna XIX - pochatok XXI st.): monohrafiia [Evolution of the scientific basis of organic agriculture in Ukraine (the second half of XIX is beginning of XXI of century): monograph]. Vinnytsia: TOV "Nilan-LTD", $550 \mathrm{~s}$. (in Ukrainian).

30. Orekhivskyi, V. D. (2017) Evoliutsiia naukovykh osnov zastosuvannia obrobitku gruntu v orhanichnomu zemlerobstvi Ukrainy (druha polovyna XIX - pochatok XXI st.) [Evolution of scientific bases of application of soil cultivation in organic agriculture of Ukraine (second half of XIX - beginning of XXI century)]. Visnyk ahrarnoi istorii, vol. 19-20. pp. 216-222. (in Ukrainian).

31. Orekhivskyi, V. D. (2018) Rozvytok zastosuvannia travosiiannia $i$ travopilnykh sivozmin $v$ orhanichnomu zemlerobstvi URSR $u$ pershii polovyni XX stolittia [Development of the use of herbivores and herbivory crop rotations in the organic agriculture of the USSR in the first half of the XX century]. Istoriia nauky i tekhniky, vol. 8. pp. 158-168. (in Ukrainian).

32. Orekhivskyi, V. D. (2018) Tendentsii rozvytku vermykultury odnoho z osnovnykh napriamiv orhanichnoho zemlerobstva $v$ Ukraini [Trends in vermiculture - one of the main areas of organic farming in Ukraine]. Eminak, no. 21, pp. 150-155. (in Ukrainian).

33. Orekhivskyi, V. D. (2018) Evoliutsiia vprovadzhennia systemy orhanichnoho zemlerobstva $v \quad$ Pryvatnomu Pidpryiemstvi "Ahroekolohiia" u druhii polovyni XX - na pochatku XXI stolit [Evolution of the organic farming system implementation in PE "Agroecology" in the second half of XX - at the beginning XXI of centuries]. Hileia, vol. 130, pp. 115-117. (in Ukrainian).

34. Orekhivskyi, V. D. (2018) Osoblyvosti rozvytku ahrarnykh pidpryiemstv $z$ vyrobnytstva orhanichnoi produktsii $v$ Ukraini (1990-ti - 2000-ni roky) [Features of development of agricultural enterprises for organic production in Ukraine $\left(1990^{\mathrm{s}}-2000^{\mathrm{s}}\right)$ ]. Hileia, vol. 133, pp. 67-69. (in Ukrainian).

35. Pysarenko, V. M., Antonets, A. S. \& Pysarenko, P. V. (2017) Systema orhanichnoho zemlerobstva ahroekoloha Semena Antontsia [Organic farming system of agroecologist Semen Antonets]. Poltava: FOP Myron, I. A. 124 s. (in Ukrainian). 
36. Pysarenko, V. M., Pysarenko, P. V. \& Ponomarenko, S. V. (2017) Orhanichne zemlerobstvo dlya pryvatnoho sektora [Organic agriculture is for a private sector]. Poltava: FOP Myron, I. A., $140 \mathrm{s.}$ (in Ukrainian).

37. Povkhan, M. F., Melnyk, I. A. \& Andryenko, V. A. (1994) Vermykultura: proyzvodstvo y yspolzovanye [Vermiculture: production and use]. Kyev: UkrNYYYTEY, 128 s. (in Russia).

38. Prymak, I. D., Roshko, V. I. \& Demydas, I. I. (2003) Ratsionalni sivozminy $v$ suchasnomu zemlerobstvi [Rational crop rotation in modern agriculture]. Bila Tserkva: BDAU, $384 \mathrm{~s}$. (in Ukrainian).

39. Prymak, I. D., Verhunov, V. A. \& Roshko, V. H. (2004) Systemy zemlerobstva: istoriia yikh rozvytku i naukovi osnovy [Systems of agriculture: history of their development and scientific basis]. Bila Tserkva: BDAU, 528 s. (in Ukrainian).

40. Prymak, I. D., Yeshchenko, V. O. \& Manko, Yu. P. (2007) Resursozberihaiuchi tekhnolohii mekhanichnoho obrobitku gruntu $v$ suchasnomu zemlerobstvi Ukrainy [Resource-saving technologies of mechanical tillage in modern agriculture of Ukraine]. Kyiv : KVITs, 272 s. (in Ukrainian).

41. Prymak, I. D., Manko, Yu. P. \& Ridei, N. M. (2010) Ekolohichni problemy zemlerobstva [Environmental problems of agriculture]. Kyiv: Tsentr uchbovoi literatury, 456 s. (in Ukrainian).

42. Shykula, M. K., Antonets, S. S. \& Andriienko, V. O. (1998) Vidtvorennia rodiuchosti gruntiv u gruntozakhysnomu zemlerobstvi: naukova monohrafiia [Soil fertility reproduction in soil protection agriculture: scientific monograph]. Kyiv: Oranta, 680 s. (in Ukrainian).

43. Shuvar, I. A. (2008) Ekolohichni osnovy znyzhennia zaburianenosti ahrofitotsenoziv [Environmental basics of agrophytocenosis weed reduction]. Lviv: Novyi Svit - 2000, 496 s. (in Ukrainian).

44. Shuvar, I. A., Sendetskyi, V. M. \& Bunchak, O. M. (2015) Vyrobnytstvo ta vykorystannia orhanichnykh dobryv: monohrafiia [Production and use of organic fertilizers: monograph]. IvanoFrankivsk: Symfoniia forte, 596 s. (in Ukrainian).

45. Stetsyshyn, P. O., Pyndus, V. V. \& Rekunenko, V. V. (2011) Osnovy orhanichnoho vyrobnytstva [Fundamentals of organic production]. Vinnytsia: Nova knyha, 552 s. (in Ukrainian). 
46. Yushchenko, O. M. (2017) Rozvytok orhanichnoho vyrobnytstva na Zhytomyrshchyni: dosvid PP "Haleks-Ahro" [Development of organic production in Zhytomyr region: experience of PE "Galex-Agro"]. Retrieved from: http://www.znau.edu.ua/media/ nauka_innovation/organic/Organic_20132.pdf (accessed 30 May 2019). (in Ukrainian).

47. Vasylev, V. P. \& Lesovoi, M. P. (1996) Ystoryia zashchyty rastenyi ot vredytelei y boleznei $v$ Ukrayne [The history of plant protection from pests and diseases in Ukraine]. Kyev: Ahrarna nauka, 132 s. (in Russia).

48. Voloshchuk, M. D., Petrenko, N. I. \& Yatsenko, S. V. (2014) Eroziia gruntiv Ukrainy: evoliutsiia teorii i praktyky: monohrafiia [Soil erosion of Ukraine: evolution of theory and practice: monograph]. Kyiv: TOV “Nilan-LTD”, 326 s. (in Ukrainian).

\section{Information about the author: Volodymyr Orekhivskyi, Doctor of Historical Sciences,} Director of Odessa state agricultural experimental station of National Academy of Agrarian Sciences of Ukraine 24, Mayatska road str., Khlibodarske Smt., Belyaivskyi district, Odessa region, 67667, Ukraine ORCID ID: orcid.org/0000-0002-3216-0514 


\section{CONSTRUCTION OF AGRICULTURAL RESEARCH IN THE CRIMEAN PENINSULA}

\section{Viktor Vergunov}

\section{INTRODUCTION}

Numerous publications of a scientific and popular science character have proved that the Crimean peninsula is a unique component of the statehood of Ukraine in its various manifestations. To the full, it concerns the issues of farming on it. Historically, the Crimean agriculture has specialized in cereals, viticulture, horticulture, vegeculture, and the cultivation of essential oils (lavender, roses, and sage). Today, arable land (63.3\% of the total agricultural area) is predominant in the structure of agricultural lands, which occupy $63 \%$ of the territory of Crimea, followed by pastures 22.9 , perennial crops 8.7 and hayfields $0.1 \%$. Unique in its construction is the history of the organizational foundations of conducting industry research on the peninsula, both in terms of beginning and development during the tsarist era, and the system of changes during the RSFSR, when the Crimean region was part of until 1954.In February 19, 1954 Presidium of the Supreme Soviet of the USSR signed by its chairman Voroshilov K.E., given the community economy, territorial proximity, close economic and cultural ties between Crimea and Ukraine, the position of the RSFSR and the USSR governments, issued a decree "On the transfer of the Crimean region from the RSFSR to the USSR", and the law "On the transfer of the Crimean region from the RSFSR to the USSR" was passedon April 26, 1954. By the way, in 1954, instead of the Crimea, the Ukrainian SSR transferred to the RSFSR part of its original territories bordering the neighboring Russian regions, and gave the city Taganrog toRostov region. These lands cumulatively by area equated to the territory of the Crimea, inhabited by 1.2 million Ukrainians.

There is an urgent need to investigate the history of the origin, formation and development of agricultural research in the Autonomous Republic of Crimea, primarily as an organization, taking into account the specific climatic conditions of the region. This approach, according 
to the findings of the author's publication ${ }^{1}$, especially in the context of general conceptual approaches to the existence of sectoral research in Ukraine, has not yet been used. Other well-known publications are tangent or highly specialized. Amongst new editions it is necessary to name the Radchenko's V.A. booklet "Identity and difference of tendencies of development of domestic and foreign experience" 2 as a successful and logical continuation of the fundamental works of Zuev V${ }^{3}$., Klepinin M.M. ${ }^{4}$ and Kochkin M.A. ${ }^{5}$ It is appropriate to highlight one of the best comprehensive works on the formation and development of domestic agricultural research in the history of its study, prepared by Helina O.Yu. ${ }^{6}$ Among other things, it included the Imperial Nikitsky Botanical Garden, established in 1811, in the list of landmark institutions in the general concept of "garden science" as a precursor to experimental agronomy in the country. This conclusion is not accidental. In the early 80's of the XIX century the same vision was reasonably proved by Balthalona G.P. in his article inthe official bulletin of the Imperial Russian Societyof Horticulture - "Bulletin of horticulture, fruit growing and vegeculture".

1 Verhunov V.A. (2012) Selskokhoziaistvennoe opytnoe delo na Krymskom poluostrove: nauchno-orhanyzatsyonnyi aspekt (k 200-letyiu sozdanyia Nikitskogo botanycheskogo sada - Natsyonalnogo nauchnogo tsentra NAAN) [Agricultural experimental work on the Crimean peninsula: scientific and organizational aspect (on the 200th anniversary of the Nikitsky Botanical Garden - National Scientific Center of the NAAS)]: nauch. doklad. Kyev : FOP Korzun D. Yu. 32 p. (in Ukrainian).

2 Radchenko V. A. (2007) Ydentychnost y razvytye tendentsyi otechestvennoho y zarubezhnoho opыtnychestva [Identity and development of trends in domestic and foreign experience]. Symferopol: OAL Symferopolskaia gorodskaia typohrafyia (SHT). 100 p. (in Ukrainian).

3 Zuev V. (1787) Puteshestvennye zapysky Vasylia Zueva ot S. Peterburga do Khersona v 1781 y 1782 godu [Travel notes of Vasil Zuev from St. Petersburg to Kherson in 1781 and 1782]. Sankt-Peterburh. 273 p. (in Russian).

4 Klepynyn N. N. (1914) Krym, putevodytel [Crimea, guide]. Simferopol. pp. 28-49. (in Ukrainian).

5 Kochkyn M. A. (1967) Pochvy, lesa i klymat gornoho Kryma i puti ikh ratsionalnogo ispolzovanyia. Nauchnye trudy [Soils, forests and climate of the Crimea mountainous and ways of their rational use. Scientific works]. Moskva: Kolos. T. XVIII. 368 p. (in Russian).

6 Elyna O. Yu. (2008) Ott sarskykh sadov do sovetskykh polei: istoryia selskokhoziaistvennykh opytnykh uchrezhdenyi XVIII - 20-e gody XX v. [From Tsarist Gardens to Soviet Fields: the History of Agricultural Experimental Institutions of the XVIII - 20th years]: v 2 t. Moskva. T. 1. 480 p., T. 2. 488 p. (in Russian). 
Moreover, he claimed that "Crimea is a copy of the Caucasus. These two quadrilaterals are so different in administrative terms, in geographical terms they have a lot in common: from the west and east, both are surrounded by the seas, and the Caspian Sea corresponds to the Azov: the regions have a steppe character, but equally to the south of it nature shines with the luxury and wealth of its gifts". While highlighting the scientific significance of the Imperial Nikitsky Botanical Garden, and especially its practical role for domestic agriculture and, above all, on the peninsula, the scientist insisted that "...almost all exotic shrubs and trees grown on the southern coast of Crimea came from this garden. ... many of these plants are for sale ... hundreds and thousands of specimens, such as, for example, palm trees, boxwoods, cypresses, laurels, evergreen oaks and more",

\section{Features of the development of the agricultural sector in the Crimea}

Our own historical research into the scientific and organizational forms of agricultural science proves that the first research institution of agrarian profile in the modern vision of this concept for Ukraine is the present Nikitsky Botanical Garden - National Scientific Center of the National Academy of Agrarian Sciences of Ukraine and that in many respectsoriginate of state interest to research in agriculture is related to humiliating defeat of the Russian army in the Crimean War of $1853-1856^{8}$, as well as the influence of all the progressive of the leading agrarian countries of Europe, especially France and some French .

${ }^{7}$ Baltalona H. P. (1882) Imperatorskyi Nikitskyi sad v Krymu [Imperial Nikitsky Garden in Crimea]. Vestnyk sadovodstva, plodovodstva $i$ ogorodnichestva (orhanmImperatorskoho Rossyiskoho obshchestva sadovodstva). Oktiabr. pp. 528-537; noiabr. pp. 567-573; dekabr. pp. 628-634. (in Russian).

${ }^{8}$ Verhunov V. A. (2000) Vynyknennia doslidnoi spravy v zemlerobstvi Ukrainy: pivdenno-skhidnyi aspekt [The origin of a research case in Ukrainian agriculture: the southeastern aspect]. Aktualni problem istorii ahrarnoi nauky pivdnia Ukrainy (Ukraine. Kyiv. Cherven', 12, 2000). Kyiv. pp. 6-7. (in Ukrainian).

${ }^{9}$ Verhunov V. A. (2009) Ahronomiia i stanovlennia nauky pro tvarynnytstvo na terenakh Ukrainy ta Frantsii (druha polovyna XVIII st. - 1920 rik) [Agronomy and the formation of animal science in the territory of Ukraine and France (second half of the eighteenth century - 1920)]. Kyiv. 280 p. (in Ukrainian). 
What was the agriculture of the region after the fifteen years of peaceful annexation of Crimea to Russia in accordance with the "Supreme Command" of Empress Catherine II of April 8, 1783 or in the process of originating the idea of finding ways to improve its productivity at the expense of scientific knowledge, it is possible to make an impression from the Sumarokov's P.I. book “A journey across Crimea and Bessarabia in 1799 with a historical and topographical description of all those places". The future academician of the Russian Academy of Sciences, the secretary adviser and the member of the Crimean commission (1801-1802) in the fashionable for that time genre of "sentimental journey", in telling, he calls Tavrida a "treasure chest".

Considering the natural and climatic conditions of Crimea, as well as the historical features of development on the way to the constituent of present Ukraine, there arethe interest and analysis of the formation of agricultural research to the events of 1917, which, of course, has many definitively unexplored moments, for example, in the general context of evolution of scientific-organizational structure of the national branch of science, its specialization, as well as the personalized contribution of individuals, in particular the French.

Considering at this angle the task, it should be noted that historically the Crimean peninsula was determined to deal with agriculture and increase the productivity of its components. As time passed, there were no other ways for this distinctive region of Ukraine. That was completely comprehensible to the state men of the tsarist era, who had the honor to deal with the problems of the development of the Crimea, beginning with Knyazh Potemkin G.O. at the end of the XVIII century, Count Vorontsov S.M. and especially the Duke de Richelieu. The latter, apparently, is associated with the origin of sectoral research on the peninsula in its modern sense, when a permanent operating institution used a special method of conducting field or laboratory research, and there was a state interest in their conduct, which is all responsible for Elina's O.Yu. socio-cultural concept of "patronage" that was systematically prepared in 2007 and dedicated to the

${ }^{10}$ Elyna O. Yu. (1995) Nauka dlia selskogo khoziaistva v Rossyiskoi imperii: formy patronazha [Science for agriculture in the Russian Empire: forms of patronage]. Sotsialnaya istoryia otechestvennoi nauki i tekhniki, no 1, pp. 40-63. (in Russian). 
$200^{\text {th }}$ anniversary of the Nikitsky Botanical Garden - National Scientific Center of NAAS ${ }^{11}$, as well as a special historical dissertation research by Potechin V.E. ${ }^{12}$ The well-illustrated Kryuk'sI. monograph "Nikitsky Botanical Garden. History and fate" should also be mentioned, which was alsodedicated to the 200th anniversary and released in $2011^{13}$. The whole process in the evolutionary context was considered by academician Adamen F.F. ${ }^{14}$

Obviously, the origin of agricultural research in agronomy,this is exactly how they talked about agriculture in the second half of the eighteenth century, was largely linked to the common European vision of its physiocratic development. Having the French roots of concept, its best theorists considered the land and agriculture is the onlya source of wealth, and "agriculture is the only productive labor"15. Otherwise it could not be for tsarist Russia, which remained an exclusively agrarian country with $90 \%$ rural populationin the early XIX century.

Continuing to find ways to maximize the benefits of agricultural production through, first of all, its realization on foreign markets after a "successful" experiment - entering the Baltic Sea, Russia had high hopes on adjacent land to the Black and Azov Seas. It is no accident in 1868 that one of the best connoisseurs of agriculture in the south of Russia and the level of his scientific support, Professor Palimpsestov I.V. (1818-1901) wrote: "In Russia... the value of the products of the earth...

11 Mytrofanov V. Y. (2007) [y dr.]. Mechta gertsoga de Ryshele - Nikitskyi botanycheskyi sad [Dream of the Duke de Richelieu - Nikitsky Botanical Garden]. Yalta: Dana Publishing, Poly PRESS. 56 p. (in Ukrainian).

12 Potekhyn V.E. (1976) Nikitskyi botanicheskyi sad v razvitii selskogo khoziaistvayuga Rossii (1812-1861 gg.) [Nikitsky Botanical Garden in the Development of Agriculture in the South of Russia (1812-1861)]: avtoref. dys. na soyskanye nauch. step. kand. yst. nauk. Moskva. 32 p. (in Russian).

${ }^{13}$ Kriukova Y. (2011) Nikitskyi botanycheskyi sad. Istoryia i sud'by (k 200-letnemu yubyleiu) [Nikitsky Botanical Garden. History and fate (on the occasion of the 200th anniversary)]. Simferopol: N. Oryanda. 415 p. (in Ukrainian).

14 Adamen F.F. (2011) Vnedrenye agronomycheskykh nauchnykh razrabotok v agropromyshlennom komplekse Ukrayny [Introduction of agronomic scientific developments in the agricultural sector of Ukraine]. Kyiv: Ahrar. nauka. 60 c. (in Ukrainian).

Potekhyn V.E. (1976) Nikitskyi botanicheskyi sad v razvitii selskogo khoziaistvayuga Rossii (1812-1861 gg.) [Nikitsky Botanical Garden in the Development of Agriculture in the South of Russia (1812-1861)]: avtoref. dys. na soyskanye nauch. step. kand. yst. nauk. Moskva. P. 5. (in Russian). 
is the value of everything received from trade, factories and factoriesin ten times. Therefore, agriculture is not only a major a source of prosperity and wealth for it, but it is also the only, and far that time, when other industries will occupy a more prominent place in this country - and still will"16. Speaking about the Crimea and the entire Southwestern region as of the middle of the 19th century, after the annihilation of serfdom in the country and active "education" of its population, this researcher, who gave more than fifty years to study the region, insisted: "...dare I say that Russia did not understand the importance of this region and therefore did not do what it should do for it" $"$.

We only need to agree with him on this vision of the issue, as well as with the fact that there is no talk of systematic research for the needs of the region's agriculture at that time. Although Palimpsestov I.V. also cites the results of individual experiments in animal husbandry, winemaking and crop production by the large landowners of the region at that time. Yes, he notes that sheep breeding makes a big profit: "We send abroad wool over 500 thousand poods"18. Assessing the state of horticulture, he insists that "...we do not have horticulture"19. He provides data on the effectiveness of winemaking of the region, namely the receipt of products "...more than 4 million species" by the provinces of the Southwestern Territory (Tavriysk, Kherson, Bessarabia and Katerinoslavsk)in 1851.He indicates a decrease in productivity in mulching from 300 poods in $1833-1835$ to 180 poods in 1849 and cites

16 Palympsestov Y. (1868) Obozrenie razlichnykh otraslei selskogo khoziaistva [Overview of various agricultural sectors]. Sbornik statei o selskom khoziaistve Yuga Rossiii zvlechennykhiz. Zapisok Imperatorskogo obshchestva selskogo khoziaistvayuzhnoi Rossii s 1830 po 1868 god. Odessa: Typ. P. Frantsova. P. 49. (in Russian).

17 Palympsestov Y. (1868) Obozrenie razlichnykh otraslei selskogo khoziaistva [Overview of various agricultural sectors]. Sbornik statei o selskom khoziaistve Yuga Rossiii zvlechennykhiz Zapisok Imperatorskogo obshchestva selskogo khoziaistvayuzhnoi Rossii s 1830 po 1868 god. Odessa: Typ. P. Frantsova. P. 50. (in Russian).

18 Palympsestov Y. (1868) Obozrenie razlichnykh otraslei selskogo khoziaistva [Overview of various agricultural sectors]. Sbornik statei o selskom khoziaistve Yuga Rossiii zvlechennykhiz Zapisok Imperatorskogo obshchestva selskogo khoziaistvayuzhnoi Rossii s 1830 po 1868 god. Odessa: Typ. P. Frantsova. P. 54. (in Russian).

19 Palympsestov Y. (1868) Obozrenie razlichnykh otraslei selskogo khoziaistva [Overview of various agricultural sectors]. Sbornik statei o selskom khoziaistve Yuga Rossiii zvlechennykhiz Zapisok Imperatorskogo obshchestva selskogo khoziaistvayuzhnoi Rossii s 1830 po 1868 god. Odessa: Typ. P. Frantsova. P. 56. (in Russian). 
the reason "...lack of land ownership for the peasantry" 20 . Among the new crops, thanks to the Frenchman Vasselen Reno, who rented Knyazh Kochubey'sland in the Crimea, showed a high efficiency of madder (Rubiatinctórum) with a yield of 400 poods and a profit of 50 tenths equal to 50,000 rubles in the space of 2 years. By the way, Steven H.H. owns the first methodological guide for growing this culture in Crimea. The second culture, no less effective for the region, according to Palimpsestov I.V., according to the data of Nikitsky Botanical Garden, was common teasel with an annual net profit of 300 rubles in silver. This leading representative of the Imperial Agricultural Society of the South of Russia, which actually synthesized everything new and progressive in the industry, and especially regarding its introduction since 1830, gaveaway the future in arable farming of Crimea to such cultures as "...hops, coloring buckwheat, which gives very valuable blue paint, indigo woad, saffron, safflower, rapeseed, sunflower..."21 in addition to traditional field crops.

Important place in the agrarian future of the region, he gave away castor and tobacco. Concerning animal husbandry Palimpsestov wrote: "The main families of our domestic animals - horses and cattle, in the total mass, that is, they are in the hands of the people, compared with the horses and cattle of England, Belgium, Holland, Germany and France,rather, they can be called parodies of these animals than real animals under the care of intelligent beings, that is, human beings" ${ }^{, 22}$. This is all about research in this area at that time.

To sum up, he calls among the reasons holding back the development of the country's productive forces, “...land ownership and

${ }^{20}$ Palympsestov Y. (1868) Obozrenie razlichnykh otraslei selskogo khoziaistva [Overview of various agricultural sectors]. Sbornik statei o selskom khoziaistve Yuga Rossiii zvlechennykhiz Zapisok Imperatorskogo obshchestva selskogo khoziaistvayuzhnoi Rossii s 1830 po 1868 god. Odessa: Typ. P. Frantsova. P. 57. (in Russian).

${ }^{21}$ Palympsestov Y. (1868) Obozrenie razlichnykh otraslei selskogo khoziaistva [Overview of various agricultural sectors]. Sbornik statei o selskom khoziaistve Yuga Rossiii zvlechennykhiz Zapisok Imperatorskogo obshchestva selskogo khoziaistvayuzhnoi Rossii s 1830 po 1868 god. Odessa: Typ. P. Frantsova. P. 58. (in Russian).

${ }^{22}$ Palympsestov Y. (1868) Obozrenie razlichnykh otraslei selskogo khoziaistva [Overview of various agricultural sectors]. Sbornik statei o selskom khoziaistve Yuga Rossiii zvlechennykhiz Zapisok Imperatorskogo obshchestva selskogo khoziaistvayuzhnoi Rossii s 1830 po 1868 god. Odessa: Typ. P. Frantsova. P. 61. (in Russian). 
use rights, millions under the gun ..., the lack of modern means of communication..." There are reasons to argue that many of the above are relevant in 150 years.

The above detailed analysis of the agriculture of the southern regions of the country, and especially of the Crimea, quite objectively reflects the picture of its condition and does not mention the systematic and, especially with the state interest, research for their solution. Demonstration results, especially in field farming, are fragmentary. In the first half of the XIX century, in fact, only the Nikitsky Botanical Garden is active for the needs of the region, mainly in the areas developed by its first director Steven H.H.: “...receiving the proper seeds and seedlings for the country at a reasonable price. And the goals set for the near future, in a concise formulation, looked like this: acclimatization and practical assistance in creating gardens" ${ }^{\prime 23}$. All these directions are successfully represented by this scientific institution till this day with the addition of studying the issues of processing of the obtained products. In this case, the Nikitsky Botanical Garden is not only leading and recognized on the peninsula, but also in the country and in the world.

\section{Formation of agricultural research}

The appearance of the Nikitsky Botanical Garden is largely related to the names of the German, academician of the Imperial Petersburg Academy of Sciences Pallas Petr Simon and Frenchman - Arman Emmanuel du Plessis Duke de Richelieu. Although we associate the name of German with stateinterest to the development of winemaking and the opening in the Crimea in 1802 of the first agricultural institution - the school of winemaking in the Sudak valley in the Achillarregion. It is this famous naturalist, traveler and first researcher of the Crimea, professor of natural history since 1767, became its first director. The establishment of the school was the starting point when the development of winemaking in the region received real state support, because at that time, “...origin ... in the land of gardening was

${ }^{23}$ Sekurov N. K. (1998) Tri vstrechi s Khrystyanom Stivenom [Three meetings with Christian Steven]. Symferopol. P. 14. (in Ukrainian). 
given to their own forces"24. In Elina's O.Yu. idea, a collection of grape vines from the estate of academician Pallas P.S.in Sudak, which before his departure to Germany he presented to the outstanding Russian agronomist Afonin M.I., as well as vines from his own collection of research nurseries, "...formed the basis for the collections of the Tavriisky (Nikitsky) Botanical Gardens". 25

Another fundamental step was made by the Kherson military governor Duke de Richelieu, who published in 1811 a report on the basis of which Emperor Alexander Pavlovich instructed him to arrange a garden "... both to improve the species of local fruit trees and plant breeding of foreign plants, corresponding to the favorable climate of the southern coast of Crimea".

In a letter addressed to the Minister of Internal Affairs of December 11, 1811, he also chose a place for the future garden Smirnova's cottage - an area of 374 acres, as well as its first director a famous botanist originally from Sweden, a graduate of the Military Medical Academy, an assistant chief inspector on mulching collegiate advisor Steven H.H. On February 22, 1815, Christian Khristianovich was elected Corresponding Member, and on October 6, 1849, he was elected an honorary member of the Imperial Academy of Sciences of Russia $^{26}$.

Duke de Richelieu also approved the first plan of scientific and organizational work of the "economic-botanical" garden, submitted January 9, 1813 in the form of Steven's H.H. Report. The governor donated 1000 rubles for the arrangement of the garden and sent 10 tea bushes from Paris ${ }^{27}$. Earl Langeron, a Frenchman by origin, who

${ }^{24}$ Shcherbakov M. F. (1911) Imperatorskyi Nikitskyi sad. 1910 [Imperial Nikitsky Garden. 1910]. Ezhehodnyk Hlavnoho Upravlenyia Zemleustroistva y Zemledelyia po Departamentu zemledelyia (hod chetvertbi). Peterburg, p. 631. (in Russian).

25 Elyna O. Yu. (2008) Ott sarskykh sadov do sovetskykh polei: istoryia selskokhoziaistvennykh opytnykh uchrezhdenyi XVIII - 20-e gody XX v. [From Tsarist Gardens to Soviet Fields: the History of Agricultural Experimental Institutions of the XVIII - 20th years]: v 2 t. Moskva. T. 1. P. 161. (in Russian).

26 Nauka. (1974) Stiven Khrystyan Khrystyanovych [Steven Christian Hristianovich]. Akademyia nauk SSSR. Personalnyi sostav. Kn. 1 (1724-1917). Moskva. P. 107. (in Russian).

${ }^{27}$ Shcherbakov M. F. (1911) Imperatorskyi Nikitskyi sad. 1910 [Imperial Nikitsky Garden. 1910]. Ezhehodnyk Hlavnoho Upravlenyia Zemleustroistva y Zemledelyia po Departamentu zemledelyia (hod chetvertbii). Peterburg, p. 635. (in Russian). 
replaced Duke de Richelieu as Governor-General of Novorossiysk, also strongly supported Steven H.H. Richelieu remembered one of his best and nobler "pet project" after leaving Russia. Through his mediation, the French Minister of the Interior, Duke Dekaz, promoted the acquisition of vines for the Magarach Winery in 1815 - "...the first nursery of winemaking knowledge in Russia" 28 from a Luxembourg nursery near Paris. Richelieu sends acorns of cork tree for garden from Parisin 1817. Thus, he maximally contributed to the development of research in the Nikitsky Botanical Garden ${ }^{29}$.

It should be noted that at the initial stage of the formation of the Nikitsky Botanical garden majority of fruit trees were imported from France for the first regular pomological garden, which was laid in 1817.Despite the positive moments, there were also negative ones. As the authors of the beautiful modern edition of "The Duke de Richelieu's Dream - Nikitsky Botanical Garden” write: “...along with the cultural plants accidentally brought weeds in the Crimea - a herbaceous ditch-bur with earth on the roots of trees from Paris in 1815, and the tree of the ailanthus, which easily became wild and a vicious weed..."30. However, every year the garden has expanded its activities in the best European traditions. Visiting it in 1818, Emperor Alexander I was amazed to see and awarded de Richelieu, who had already left the country, the highest award of the empire - The Order of St. Andrew the First-Called for the transformation of the Novorossiysk land and garden, as well as southern Crimea, which the great son of the French people considered "more beautiful than the French Riviera".

Interestingly, the final decision to organize the water supply of the Nikitsky Botanical Garden, which actually exists to this day, goes under the name of the Minister of Agriculture and State Property of the Russian Empire, Ermolov O.S. and French scientist, specialist in

${ }^{28}$ Shcherbakov M. F. (1911) Imperatorskyi Nikitskyi sad. 1910 [Imperial Nikitsky Garden. 1910]. Ezhehodnyk Hlavnoho Upravlenyia Zemleustroistva y Zemledelyia po Departamentu zemledelyia (hod chetvertbii). Peterburg, pp. 630-645. (in Russian).

${ }^{29}$ Shcherbakov M. F. (1911) Imperatorskyi Nikitskyi sad. 1910 [Imperial Nikitsky Garden. 1910]. Ezhehodnyk Hlavnoho Upravlenyia Zemleustroistva y Zemledelyia po Departamentu zemledelyia (hod chetvertbii). Peterburg, p. 637. (in Russian).

${ }^{30}$ Mytrofanov V. Y. (2007) [y dr.]. Mechta gertsoga de Ryshele - Nikitskyi botanycheskyi sad [Dream of the Duke de Richelieu - Nikitsky Botanical Garden]. Yalta: Dana Publishing, Poly PRESS. p. 26. (in Ukrainian). 
hydrology and speleology Martel. In the summer of 1903, State Secretary Yermolov A.S. made a trip to Crimea. Along with other objects, he inspected the Salgirgovernment-owned Garden near Simferopol, as well as the Imperial Nikitsky Botanical Garden, which the minister had previously visited on August 30, 1893, in connection with the project of reorganizing the gardening school, which was part of the garden ${ }^{31}$. His current arrival was due to urgent problems with the water supply of the garden.

To this end, Yermolov A.S. took along a well-known specialist in Europe, Martel, who, first of all, was formally invited "...to hydrologically investigate the Black Sea coast of the Caucasus". In advance, before the official visit of the Minister, Martel became acquainted with the problems of Nikitsky Botanical Garden'swater supply. During the discussion, the French specialist offered constructive suggestions, which, in general, Yermolov A.S. approved for action ${ }^{32}$. A little later, under the impression of what he saw, in his report at the 2nd All-Russian Congress of Experimental Affairs, Yermolov A.S. not only put the Imperial Nikitsky Botanical Garden first among those institutions that should be engaged in "...the broad production of experiments and the acclimatization of plants in our country, interesting scientifically or effective from a practical point of view..." but also proposed to take charge of developing a general program of this type of research in the empire ${ }^{33}$.

The results of a basic study that looks at the evolutionary path traveled on the Crimean peninsula from the gardens and parks of the Southern coast of Crimea to the existence in the region of agricultural

${ }^{31}$ Petrov Y. P., Vereshchahyn N. V. (ed.) (1893) O puteshestvii po Rossii Ministra Zemledelyia [About the trip to Russia of the Minister of Agriculture]. Vestnik russkogo selskogo khoziaistva, no 36 (4 sentiabria), p. 609. (in Russian).

32 Typohraf. V. F. Kyrshbauma. (1904) Obzor deiatelnosti Ministerstva zemledelyia i gosudarstvennykh imushchestv za desiatyi god ego sushchestvovanyia [Overview of the activities of the Ministry of Agriculture and State Property for the tenth year of its existence]. Sankt-Peterburh. P. XII. (in Russian).

${ }^{33}$ Kudashev V. A. (ed.) (1903) O neobkhodymosty luchshei orhanizatsyy opytnykh kultur, a ravno opytov po akklymatyzatsi i novykh i maloyzvestnykh rastenyi $\mathrm{v}$ razlychnykh mestnostiakh Rossii. Doklad 2-mu siezdu A. S. Ermolova [On the need for better organization of experimental crops, as well as experiments on the acclimatization of new and little-known plants in various places of Russia. Report of A. S. Ermolov to the 2nd Congress]. Zemledelcheskaia hazeta, no 5, p. 155. (in Russian). 
research as an organization, are summarized in a series of publications by Stashkina (Adamen)A.F. She identified its main styles and trends: monastic, Dutch, forest, august, dangling, "paradise" garden, world nature, which are generally attributed to the European. No less noticeable was the Asian influence of Chinese, Japanese and Moorish styles. Their successful application was facilitated by Englishmen and Frenchmen who taught Russian students.

After all, industry research has developed as a component of national culture ${ }^{34}$. The rest of all components of agriculture of the Crimean peninsula has developed due to the evolution of sectoral scientific and educational thought in the country. In our view, this is a principled approach to what we are investing today in the concept of "agricultural research". It is not necessary to downplay the value, according to Elina O.Yu., the initiative of "patrons" from personal landowners to various types of state monopoly. But if there were no real victories or discoveries of domestic agricultural science, there would be no desire to invest money in this business.

Let's consider the scientific and organizational structure of the network of agricultural research institutions of the Crimea as of 1913 inclusive - the period of the highest prosperity of the Russian Empire on agriculture, referring to the official statistical reporting of the Department of Agriculture ${ }^{35}$. Interestingly, the Nikitsky Botanical Garden is not mentioned in it as the subject of a functioning network of agricultural institutions in the country. According to the "Data Collection", in 1910 there were 130 research institutions reporting on their activities, and in 1913 there were 195in the country. Structurally, they were divided into groups: 1) laboratories, 2) research stations, 3) research fields, 4) research farms, 5) nurseries. This did not include research parcels of educational branch institutions. Of the 256 educational institutions, only 54 were currently engaged in

${ }^{34}$ Adamen A. F. (2009) Evoliutsyia landshaftov v Krymu (s peryoda antychnostypo nastoiashchee vremia) [The evolution of landscapes in the Crimea (from the period of antiquity to the present)]. Ahroekolohichnyi zhurnal, Cherv (spets. vyp.), pp. 27-31. (in Ukrainian).

${ }^{35}$ Typo-lytohr. M. P. Frolovoi. (1911) Sbornyk svedenyi o selskokhoziaistvennыkh орыtnыkh uchrezhdenyiakh Rossyy (po dannыm anketы 1910 hoda) [Collection of information on agricultural experimental institutions of Russia (according to the data of 1910).]. Sankt-Peterburg. 394 p. (in Russian). 
research.According theofficial reporting on this category, Tavriyan province was officially represented by the Nikitsky School of Horticulture and Viticulture with an experimental site of 1 tenth.

It is clear that these experiments were rather demonstrative. The calculations showed that the empire's research network, available for analysis, was served by 215 workers with tertiary and secondary education and 265 without education (technical staff) ${ }^{36}$. In addition, 42 faculty members and civil servants were involved in this work. The cost per scientist at that time averaged 1411 rubles. The total budget of the existing network of the country was 627780 rubles $^{37}$.

According to official reports, as of 1913, the research network of sectoral establishments of the Tavriya province consisted of only four institutions, namely: the Simferopol Research Field, the Oleshkovsky state-owned Grapes Nursery, the Oleshkovka Tobacco Plot and the Yalta Tobacco Plantation ${ }^{38}$. However, under the current territorial division of Ukraine, both Oleshkiv stations are no longer owned by the Crimea. However, their main function of scientific support they certainly performed for the peninsula. Thus, the Oleshkovsky stateowned Grape Nursery (aka disinfectant) was founded by the Odessa Philocserny Committee and was located in two miles from Oleshka. The nursery was established in 1897 with public funds. Until January 1, 1908 he was governed by Bertenson V.A. and then Tairov V.E. The area of experiments is 34 arpent (tenths) of quicksand. First,it was laid to breed American and then European vines and a vineyard. Less known is the activity of the Simferopol Research Field, created in 1908 by the Simferopol County Zemstvo, located in 20 miles away

${ }^{36}$ Typo-lytohr. M. P. Frolovoi. (1913) Sbornyk svedenyi o selskokhoziaistvennykh opytnykh uchrezhdenyiakh Rossyy (po dannym ankety 1912 hoda) [Collection of information on agricultural experimental institutions of Russia (according to the data of the 1912)]. Sankt-Peterburg. Vol. 2. P. 67. (in Russian).

37 Typo-lytohr. M. P. Frolovoi. (1913) Sbornyk svedenyi o selskokhoziaistvennykh opytnykh uchrezhdenyiakh Rossyy (po dannym ankety 1912 hoda) [Collection of information on agricultural experimental institutions of Russia (according to the data of the 1912)]. Sankt-Peterburg. Vol. 2. P. 87. (in Russian).

38 Typo-lytohr. M. P. Frolovoi. (1913) Sbornyk svedenyi o selskokhoziaistvennykh opytnykh uchrezhdenyiakh Rossyy (po dannym ankety 1912 hoda) [Collection of information on agricultural experimental institutions of Russia (according to the data of the 1912)]. Sankt-Peterburg. Vol. 2. P. 67. (in Russian). 
from the city. Schneider F.F. provided his land for research for 10 years. The area of the experiments was 10 tenths.

The Yalta Experimental Tobacco Plantation was organized in 1911 by the Yalta County Zemstvo within the city. Experimental area of 0.5 tenthswas rented.

The research program as a component for all Crimean research institutions that studied theproblem of tobacco was developed by Euko V.E. It was approved by a special meeting in Simferopolin 1910.The general program was formed by Egiza S.A., Dahl K.V., Yevko V.E. and Khodasevich B.C. The first report of the plantation was sent to the Department of Agriculturein 1911.Therewas found the information about another research institution - Feodosia Research Mountain Mining and Cultural Forestry, classified by the Department of Agriculture as agricultural. It was created in 1902 by the Forest Department at a distance of 111 miles from Simferopol on full state content of 7,000 rubles. The area of the experimental site was 180 tenths. To the listed network of sectoral research institutions that operated in the Tavrian province before the revolutionary events of 1917, one more should be added. For various reasons, its activities are also almost forgotten and require additional historical exploration. In 1888, the Bartoshevich'sproperty in the Otuz Valley of the Feodosia County of Tavriya Province was purchased by the Ministry of State Property for the construction of an exemplary production holding of about 23 acres. Certain organizational problems related to world market prices did not allow the project to unfold immediately ${ }^{39}$.

Oddly enough, it is also worth mentioning that the Izmail nursery of the American Vines, created by the Department of Agriculture in 1897 in two versts from the city of Izmail, was connected withthe Nikitsky Botanical Garden, first of all, through scientific and methodological consultations and activities. In 1906 it was transferred to the Izmail Zemstvo and served the similarly-named district. It had 8 nurseries of American vines.Initially, it occupied 5 acres of land, and in 1908 - already 20 acres.

${ }^{39}$ Romanovskyi-Romanko A. S. (1910) Vynohradnyky y maslychnыe pytomnyky Departamenta zemledelyia [Vineyards and oil nurseries of the Department of Agriculture. 1909 1909]. Ezhehodnyk Hlavnoho upravlenyia zemleustroistva y zemledelyia po Departamentu zemledelyia (hod tretyi). Sankt-Peterburg : Typ. V. F. Kyrshbauma. P. 142. (in Russian). 
In 1909 a building for the manager, a workshop for vaccinations, a greenhouse and a cellar was built. The fight against phylloxera and the promotion of viticulturewasthe main area of scientific interest.On average, 100,000 thin cuttings for grafting and 50,000 thick cuttings were planted annually. The first sold at a price of 3 rubles for one thousand pieces, the other -5 rubles $^{40}$. In fact, in the state reports, this is all information about the work of Crimean research institutions until 1913. However, in 1917, according to Elina's O.Yu. data, there were $370^{41}$ research establishments in Russia, and according to other sources $-378^{42}$, which, of course, also increased in number over the next four yearsin the Tavria province. It was found that a special inspector, who was located in the city of Simferopol, was engaged in the general issues of agriculture in Tavria province. Dahl K.V. was appointed to this position in 1910.ShleiferV.A. provided agronomic assistance to the population and Shchuko S.S. worked at the position of the provincial agronomist-land manager. It should be noted that agrarian scientists who worked in the Crimea, repeatedly until 1917, raised the issue of the creation of a special Central Agricultural Research Station in order to summarize the introduction of everything new by coordinating efforts. In this regard, it is of interest "Project of organization of research institutions", which was prepared by Klepinin M.M. ${ }^{43}$ and submitted by the Provincial Agricultural Councilon December 6, 1912.

${ }^{40}$ Romanovskyi-Romanko A. S. (1910) Vynohradnyky y maslychnыe pytomnyky Departamenta zemledelyia [Vineyards and oil nurseries of the Department of Agriculture. 1909 1909]. Ezhehodnyk Hlavnoho upravlenyia zemleustroistva y zemledelyia po Departamentu zemledelyia (hod tretyi). Sankt-Peterburg : Typ. V. F. Kyrshbauma. P. 139. (in Russian).

41 Elyna O. Yu. (2008) Ott sarskykh sadov do sovetskykh polei: istoryia selskokhoziaistvennykh opytnykh uchrezhdenyi XVIII - 20-e gody XX v. [From Tsarist Gardens to Soviet Fields: the History of Agricultural Experimental Institutions of the XVIII - 20th years]: v 2 t. Moskva. T. 1, P. 120. (in Russian).

42 Elyna O. Yu. (1995) Nauka dlia selskogo khoziaistva v Rossyiskoi imperii: formy patronazha [Science for agriculture in the Russian Empire: forms of patronage]. Sotsialnaya istoryia otechestvennoi nauki i tekhniki, no 1, p. 61. (in Russian).

${ }^{43}$ Klepynyn N. N. (1913) Proekto rhanyzatsyy opytnykhuch rezhdenyi v Tavryiskoi gubernii: (doklad Gubernskomu Selskokho ziaistvennomu Sovetu 6 dekabria 1912 goda) [The project of the organization of experimental institutions in the Tavrian 
The project partly confirms our conclusion that there is an interest in the development of research in agriculture in different sections of society as "... a consequence of the general development of agronomic assistance to the population". According to Klepinin M.M., the issue of the organization of agricultural research institutions in Tavriya province was the subject of active discussion at various meetingsand sessions in 1911-1912.

Today, practically all well-known researchers of domestic research, for the needs of agriculture, call the Wiener's V.V.project on the division of the country into agricultural areas asone of the fundamental moments of its further development in general and organizational approaches in particular, which was based on botanical and geographical principles ${ }^{44}$. Thus, in 1908 the country was divided into 6 crop regions with 27 districts. According to Viner V.V. Tavriyaprovince became the part of the steppe region with chernozem and chestnut soils.But this successfully implemented plan was preceded by another project, widely discussed by experts and published in 1898 by a special brochure "The Project Organization of Research Fields in Russia"45, designed by Rothmistrov V.R.

The final impetus for the implementation of the system of regional organization of domestic research in the empire was the statement of 34 members of the State Duma "...to take decisive measures ... to identify the best ways of managing in certain parts of Russia, which differ in terms of climate, soil and economic environment..." and "...to immediately set up, on the correct grounds, a network of properly equipped agricultural research institutions...”.

Such a small legal and organizational excursion to the principled approaches to the organization of research institutions in the Tavriya province is no accident.

province: (report to the Provincial Agricultural Council on December 6, 1912)]. Simferopol: Typ. Tavryisk. Hub. Zem-va. 20 p. (in Ukrainian).

44 Elyna O. Yu. (2008) Ott sarskykh sadov do sovetskykh polei: istoryia selskokhoziaistvennykh opytnykh uchrezhdenyi XVIII - 20-e gody XX v. [From Tsarist Gardens to Soviet Fields: the History of Agricultural Experimental Institutions of the XVIII - 20th years]: v 2 t. Moskva. T. 1. 480 p., T. 2. 488 p. (in Russian).

45 Rotmystrov V. H. (1898) Proekt orhanizatsii opytnykh polei v Rossii [The project for the organization of experimental fields in Russia]. Odessa: Ekonomycheskaia typohraf. ilytohraf. 108 p. (in Ukrainian). 
Klepinin M.M. proposed his plan as a form of implementation of the Viner'svision, but rather- as its optimization on soil features. According to Viner V.V. the Odessa regional station's activity would be spread to the Crimean Peninsula, which explored chestnut soils. The other part of the Tavriya province - continental - with the black earths (chernozem) should be considered by the Katerynoslav station. For the first time, having introduced in 1907 the concept of "South Russian chernozem" instead of the existing "chocolate chernozem", he insisted that Crimea should be in coordination area of the Ekaterinoslav Oblast Station. Moreover, he proposed, additionally, taking into account the specificity of the Crimea, to create appropriate district institutions research fields and sites at the Katerynoslav Provincial Zemstvo Administration'smeeting on May 21-23, 1912. By the way, at a meeting in St. Petersburg on the organization of agricultural research business in 1908, the types of research institutions were also developed: 1) district regional research station, 2) in-district or local research station, 3) research fields and relevant institutions in other branches of rural farms, 4) research sites, 5) collective experiences.

Thus, as of the beginning of 1913, due to the relevant decision of the Tavriya Provincial Agricultural Council, it was proposed to expand the existing network of research sectoral institutions by creating: 1) a Central station, 2) 3 experimental fields and 3) a network of experimental sites. One of the stations was planned to be built on the Kerch Peninsula. The basic tasks or directions for the existing and established research institutions in the province are defined: "a) study of the province in agricultural and natural-historical relation for the development of more rational methods of arable farming and methods of weed and pest control, b) integration of activities of district research institutions ofprovince; c) the satisfaction of requests by the agronomic staff of the province. ${ }^{46}$ Research funding was proposed to successfully resolve the raised issues: 50\% from the Department of Agriculture, $25 \%$ from provincial zemstvo and $25 \%$ from county zemstvo.

${ }^{46}$ Klepynyn N. N. (1913) Proekto rhanyzatsyy opytnykhuch rezhdenyi v Tavryiskoi gubernii: (doklad Gubernskomu Selskokho ziaistvennomu Sovetu 6 dekabria 1912 goda) [The project of the organization of experimental institutions in the Tavrian province: (report to the Provincial Agricultural Council on December 6, 1912)]. Simferopol: Typ. Tavryisk. Hub. Zem-va. P. 11-12. (in Ukrainian). 
As time has shown, many of the Viner's V.V, Klepinin's M.M. and Rotmistrov's V.R. projects was finally implemented by the Soviet authorities, optimizing the administrative structure of Crimea. Thanks to $100 \%$ budget financing, in 1923 , it created not only a regional station, which was Klepinin's M.M. desire (now - the Institute of Agriculture of Crimea), but also the corresponding vertical of research and demonstration institutions of a certain specialization, which today is in search of optimal ways of adaptation in the conditions declared by the executive power of European integration and manifestations of globalization. For this, more than ever, the historical experience of the existence of a research before 1917, at least in matters of budgetary and organizational activity, may come in handy.

\section{SUMMARY}

The development of agricultural research in the Crimean Peninsula until 1920 was the result of the general evolution of its scientific and organizational approaches in the Russian Empire. It can be divided into four periods. The first - related to the creation of the NBG in 1812 and the search for forms of organization of research - its end came in 1897. Scientific research was largely unsystematic, dominated by the private initiative of large landowners to improve the productivity of crops and animals. Important role in the development of sectoral research during this period belonged to some prominent figures from France. The second period begins with the creation of the Oleshkovsky state vineyard nursery in 1897, which became the first state agricultural research institution for the needs of the region with an approved scientific program that envisaged adherence to appropriatemethods in conducting research in agronomy, ending in 1917.His general feature remained the dominance of the crop component of agronomic research, but with a specialization. The third period began in 1923 and ended on February 20, 2014 with a dividing into four conditional subperiods: 1923-1941, 1941-1944, 1944-1954, and 1954-2014. At the beginning of the first subperiod, "Crimean California" model, under the initiative of the American charity "Joint" led by Rosen I. and the relevant decision of the CEC of the RSFSR, was worked out. Characterized by the regional organization of agricultural research in the Crimean peninsula since 1923. It can be considered as a successful implementation of the Viner's V.V. project with Klepinin's addition. 
Since 1929, the regional form of sectoral research in the Crimea has become an integral part of the national coordinating system in the form of the All-Union Academy of Agricultural Sciences (AUAAS) through the institutionalized specialization of different areas of research.The only peculiarity was that a small number of Scientific Research Institutions functionedin the Crimean Peninsula, and sectoral research was directed exclusively to the needs of the RSFSR,as before the revolutionary events of 1917. During the Soviet-German War of 1941-1944, the Crimean Peninsula was merged in the General District of Crimea. All studies were conducted through the Agricultural and Forestry Research Center with headquarters in Kiev. In 1943 an independent service was created - the Regional Research Center in Kiev. It includes the sectoral research institutes, which are divided into three groups. A new revival of American preferential loansto Jewish immigrants to the Crimea, initiated by US President Roosevelt F., took place in 1944. Officially, the regional construction of agricultural research on the Crimean peninsula was introduced by the Resolution No. 259 of the Central Committee of the CPSU and the Council of Ministers of the USSR "On Measures to Improve the Work of Scientific Research Institutions(SRI) on Agriculture" of February 14, 1956. The methodological guidance of the whole cycle of Scientific Researches was performed by Ukrainian Academy of Agricultural Sciences(UAAS).Part of the experimental base of the Crimean peninsula was donated to the newly established sectoral Scientific Research Institutions, which have been involved in all the tasks of improving the productivity of fields and farms. After the decision of the Central Committee of the Communist Party of Ukraine and the RS SSR 487 of May 4, 1962 "On the elimination of UAAS and the formation of the department of agriculture in the Academy of Sciences of the USSR". The network of the agrarian profile of the Crimean Peninsula's SRIs became directly subordinated to the Ministry of Agriculture of Ukr.SSR or the Ministry of Agriculture of USSR. To accelerate the pace of agricultural development, on October 2, 1968, according to the Resolution of the Central Committee of the CPSU and the CM of the USSR "On measures for the further improvement of the Scientific Research in the field of agriculture" the Southern Branch (SB) of AUAAS was created. The changes in subordination occurred after the adoption of the CM of the USSR by Resolution No. 279 of 
September 22, 1990 "On the Establishment of the UAAS" in order to enhance the development of basic and applied research aimed at further improving the scientific support of agroindustrial complex. The Centers for Scientific support of the industrial productionwere created on the basis of regional state agricultural research stations and individual research institutes, among them the Autonomous Republic of Crimea. The attempt to change over agrarian science toan innovative component has led to the adoption of a new approach - the creation of regional educational research and production complexes. Institute of Agriculture of Crimea of NAASwasthe First among them. The fourthperiod of organizational construction of agricultural research in the Crimean peninsula is due, first of all, to the political component of the Russian Federation, namely its annexation. Local sectoral Scientific Research Institutionsare part of the coordination and budgetary funding system of the Russian Academy of Sciences. The research network, its functions and principles have remained virtually unchanged compared to functioning within the NAAS.

\section{REFERENCES}

1. Adamen A. F. (2009) Evoliutsyia landshaftov v Krymu (s peryoda antychnostypo nastoiashchee vremia) [The evolution of landscapes in the Crimea (from the period of antiquity to the present)]. Ahroekolohichnyi zhurnal, Cherv (spets. vyp.), pp. 27-31. (in Ukrainian).

2. Adamen F. F. (2011) Vnedrenye agronomycheskykh nauchnykh razrabotok $\mathrm{v}$ agropromyshlennom komplekse Ukrayny [Introduction of agronomic scientific developments in the agricultural sector of Ukraine]. Kyiv: Ahrar. nauka. (in Ukrainian).

3. Baltalona H. P. (1882) Imperatorskyi Nikitskyi sad v Krymu [Imperial Nikitsky Garden in Crimea]. Vestnyk sadovodstva, plodovodstva $i$ ogorodnichestva (orhanmImperatorskoho Rossyiskoho obshchestva sadovodstva). Oktiabr. pp. 528-537; noiabr. pp. 567-573; dekabr. pp. 628-634. (in Russian).

4. Verhunov V. A. (2009) Ahronomiia i stanovlennia nauky pro tvarynnytstvo na terenakh Ukrainy ta Frantsii (druha polovyna XVIII st. - 1920 rik) [Agronomy and the formation of animal science in the territory of Ukraine and France (second half of the eighteenth century - 1920)]. Kyiv. (in Ukrainian). 
5. Verhunov V. A. (2000) Vynyknennia doslidnoi spravy v zemlerobstvi Ukrainy: pivdenno-skhidnyi aspekt [The origin of a research case in Ukrainian agriculture: the southeastern aspect]. Aktualni problem istorii ahrarnoi nauky pivdnia Ukrainy (Ukraine. Kyiv. Cherven', 12, 2000). Kyiv. pp. 6-7. (in Ukrainian).

6. Verhunov V. A. (2012) Selskokhoziaistvennoe opytnoe delo na Krymskom poluostrove: nauchno-orhanyzatsyonnyi aspekt (k 200letyiu sozdanyia Nikitskogo botanycheskogo sada - Natsyonalnogo nauchnogo tsentra NAAN) [Agricultural experimental work on the Crimean peninsula: scientific and organizational aspect (on the 200th anniversary of the Nikitsky Botanical Garden - National Scientific Center of the NAAS)]: nauch. doklad. Kyev : FOP KORZUN D. Yu. (in Ukrainian).

7. Elyna O. Yu. (1995) Nauka dlia selskogo khoziaistva v Rossyiskoi imperii: formy patronazha [Science for agriculture in the Russian Empire: forms of patronage]. Sotsialnaya istoryia otechestvennoi nauki i tekhniki, no 1, pp. 40-63. (in Russian).

8. Elyna O. Yu. (2008) Ott sarskykh sadov do sovetskykh polei: istoryia selskokhoziaistvennykh opytnykh uchrezhdenyi XVIII 20-e gody XX v. [From Tsarist Gardens to Soviet Fields: the History of Agricultural Experimental Institutions of the XVIII - 20th years]: v 2 t. Moskva. T. 1., T. 2. (in Russian).

9. Zuev V. (1787) Puteshestvennye zapysky Vasylia Zueva ot S. Peterburga do Khersona v 1781 y 1782 godu [Travel notes of Vasil Zuev from St. Petersburg to Kherson in 1781 and 1782]. Sankt-Peterburh. (in Russian).

10. Klepynyn N. N. (1914) Krym, putevodytel [Crimea, guide]. Simferopol. (in Ukrainian).

11. Klepynyn N. N. (1913) Proekto rhanyzatsyy opytnykhuch rezhdenyi v Tavryiskoi gubernii: (doklad Gubernskomu Selskokho ziaistvennomu Sovetu 6 dekabria 1912 goda) [The project of the organization of experimental institutions in the Tavrian province: (report to the Provincial Agricultural Council on December 6, 1912)]. Simferopol: Typ. Tavryisk. Hub. Zem-va. (in Ukrainian).

12. Kochkyn M. A. (1967) Pochvy, lesa i klymat gornoho Kryma i puti ikh ratsionalnogo ispolzovanyia. Nauchnye trudy [Soils, forests and climate of the Crimea mountainous and ways of their rational use. Scientific works]. Moskva: Kolos. T. XVIII. (in Russian). 
13. Kriukova Y. (2011) Nikitskyi botanycheskyi sad. Istoryia i sud'by (k 200-letnemu yubyleiu) [Nikitsky Botanical Garden. History and fate (on the occasion of the 200th anniversary)]. Simferopol: N. Oryanda. (in Ukrainian).

14. Mytrofanov V. Y. (2007) [y dr.]. Mechta gertsoga de Ryshele - Nikitskyi botanycheskyi sad [Dream of the Duke de Richelieu - Nikitsky Botanical Garden]. Yalta: Dana Publishing, Poly PRESS. (in Ukrainian).

15. Kudashev V. A. (ed.) (1903) O neobkhodymosty luchshei orhanizatsyy opytnykh kultur, a ravno opytov po akklymatyzatsi i novykh i maloyzvestnykh rastenyi v razlychnykh mestnostiakh Rossii. Doklad 2-mu siezdu A. S. Ermolova [On the need for better organization of experimental crops, as well as experiments on the acclimatization of new and little-known plants in various places of Russia. Report of A. S. Ermolovto the 2nd Congress]. Zemledelcheskaia hazeta, no 5, pp. 155. (in Russian).

16. Petrov Y. P., Vereshchahyn N. V. (ed.) (1893) O puteshestvii po Rossii Ministra Zemledelyia [About the trip to Russia of the Minister of Agriculture]. Vestnik russkogo selskogo khoziaistva, no 36, p. 609. (in Russian).

17. Typohraf. V. F. Kyrshbauma. (1904) Obzor deiatelnosti Ministerstva zemledelyia i gosudarstvennykh imushchestv za desiatyi god ego sushchestvovanyia [Overview of the activities of the Ministry of Agriculture and State Property for the tenth year of its existence]. Sankt-Peterburh. (in Russian).

18. Palympsestov Y. (1868) Obozrenie razlichnykh otraslei selskogo khoziaistva [Overview of various agricultural sectors]. Sbornik statei o selskom khoziaistve Yuga Rossiii zvlechennykhiz Zapisok Imperatorskogo obshchestva selskogo khoziaistvayuzhnoi Rossii s 1830 po 1868 god. Odessa: Typ. P. Frantsova. (in Russian).

19. Potekhyn V. E. (1976) Nikitskyi botanicheskyi sad v razvitii selskogo khoziaistvayuga Rossii (1812-1861 gg.) [Nikitsky Botanical Garden in the Development of Agriculture in the South of Russia (1812-1861)]: avtoref. dys. na soyskanye nauch. step. kand. yst. nauk. Moskva. (in Russian).

20. Rotmystrov V. H. (1898) Proekt orhanizatsii opytnykh polei v Rossii [The project for the organization of experimental fields in Russia]. Odessa: Ekonomycheskaia typohraf. ilytohraf. (in Ukrainian). 
21. Radchenko V. A. (2007) Ydentychnost y razvytye tendentsyi otechestvennoho y zarubezhnoho opttnychestva [Identity and development of trends in domestic and foreign experience]. Symferopol : OAL Symferopolskaia gorodskaia typohrafyia (SHT). (in Ukrainian).

22. Romanovskyi-Romanko A. S. (1910) Vynohradnyky y maslychnыe pytomnyky Departamenta zemledelyia [Vineyards and oil nurseries of the Department of Agriculture. 1909]. Ezhehodnyk Hlavnoho upravlenyia zemleustroistva y zemledelyia po Departamentu zemledelyia (hod tretyi). Sankt-Peterburg : Typ. V. F. Kyrshbauma. (in Russian).

23. Typo-lytohr. M. P. Frolovoi. (1911) Sbornyk svedenyi o selskokhoziaistvennykh opytnykh uchrezhdenyiakh Rossyy (po dannym ankety 1910 hoda) [Collection of information on agricultural experimental institutions of Russia (according to the data of 1910)]. Sankt-Peterburg. (in Russian).

24. Typo-lytohr. M. P. Frolovoi. (1913) Sbornyk svedenyi o selskokhoziaistvennykh opytnykh uchrezhdenyiakh Rossyy (po dannym ankety 1912 hoda) [Collection of information on agricultural experimental institutions of Russia (according to the data of the 1912)]. Sankt-Peterburg. Vol. 2. (in Russian).

25. Sekurov N. K.(1998) Tri vstrechi s Khrystyanom Stivenom [Three meetings with Christian Steven]. Symferopol. (in Ukrainian).

26. Nauka. (1974) Stiven Khrystyan Khrystyanovych [Steven Christian Hristianovich]. Akademyia nauk SSSR. Personalnyi sostav. Kn. 1 (1724-1917). Moskva. (in Russian).

27. Shcherbakov M. F. (1911) Imperatorskyi Nikitskyi sad. 1910 [Imperial Nikitsky Garden. 1910]. Ezhehodnyk Hlavnoho Upravlenyia Zemleustroistva y Zemledelyia po Departamentu zemledelyia (hod chetvertbii). Peterburg, pp. 630-645. (in Russian).

\section{Information about the author: Viktor Vergunov,} Doctor of Agricultural Sciences, Professor,

Academician of NAAS, Director, National Scientific Agricultural Library of NAAS 10, Heroiv Oborony St., Kyiv, Ukraine ORCID ID: orcid.org/0000-0002-5476-4845 
NOTES 
NOTES 
Publishing house "Liha-Pres"

9 Kastelivka str., Lviv, 79012, Ukraine

44 Lubicka str., Toruń, 87-100, Poland

Printed by the publishing house "Liha-Pres"

Passed for printing: November 25, 2019.

A run of 150 copies. 